UNIVERSIDADE DE SÃO PAULO

ESCOLA DE COMUNICAÇÕES E ARTES

PAULA PULITI

A Financeirização do Noticiário Econômico no Brasil (1989-2002)

São Paulo

2009 


\section{PAULA PULITI}

\section{A Financeirização do Noticiário Econômico no Brasil (1989-2002)}

Tese apresentada à Escola de Comunicações e Artes da Universidade de São Paulo como requisito parcial para obtenção do título de Doutor em Ciências da Comunicação.

Área de Concentração: Interfaces Sociais da Comunicação. Linha de pesquisa: Políticas e Estratégias de Comunicação.

Orientador: Prof. Dr. Bernardo Kucinski

São Paulo 


\section{FICHA CATALOGRÁFICA}

Puliti, Paula

A Financeirização do Noticiário Econômico (1989-2002). - São Paulo: P. Puliti, 2009.

286p. + anexos.

Tese (Doutorado) - Departamento de Jornalismo e Editoração/Escola de Comunicações e Artes/USP.

Orientador: Prof. Dr. Bernardo Kucinski.

Bibliografia

1. Jornalismo brasileiro. 2. Noticiário econômico. 3. Discurso econômico - imprensa. 4. Discurso financeiro - imprensa. 5. Puliti, Paula. Kucinski, Bernardo. I. Título. 


\section{FOLHA DE APROVAÇÃO}

\section{Paula Puliti}

\section{A Financeirização do Noticiário Econômico (1989-2002)}

Aprovado em:

Tese apresentada à Escola de Comunicações e Artes da Universidade de São Paulo como requisito parcial para obtenção de título de Doutor.

Área de Concentração: Interfaces da Comunicação.

Prof. Dr.

Instituição: Assinatura:

Prof. Dr.

Instituição: Assinatura:

Prof. Dr. Instituição: Assinatura:

Prof. Dr. Instituição: Assinatura:

Prof. Dr.

Instituição: Assinatura: 
Ao Caio. 


\section{AGRADECIMENTOS}

Ao Prof. Bernardo Kucinski, que muito me ensinou nos anos de convivência.

À Escola de Comunicações e Artes, por ter aceitado minha proposta de pesquisa.

Aos amigos Celia Froufe e Francisco Carlos de Assis, não apenas pela amizade e pelo apoio, mas sobretudo pela inspiração.

Às amigas de sempre, que me possibilitaram intensa troca de ideias.

À minha mãe, Teresinha, por tudo. 


\section{RESUMO}

PULITI, P. A Financeirização do Noticiário Econômico (1989-2002). 2009. 150f. Tese (Doutorado) - Escola de Comunicações e Artes, Universidade de São Paulo, São Paulo, 2009.

O conteúdo do noticiário econômico praticado nos jornais gerais brasileiros iniciou um processo de transformação a partir da segunda metade dos anos 1980, que consistiu em substituir suas tradicionais fontes de informação, que eram os grandes empresários e produtores rurais, e em menor escala acadêmicos e sindicalistas, por um novo agente que surgia na cena nacional, o economista do mercado financeiro. Formado pelos padrões norte-americanos do neoliberalismo, segundo os quais as forças que levam ao desenvolvimento só se realizam quando, liberadas das amarras do Estado, se encontram e tomam suas decisões num ambiente de mercado livre, esse profissional conquistou espaço cativo nos jornais gerais, levando ao processo de financeirização. O termo, praticamente um neologismo, refere-se aqui ao predomínio no noticiário econômico de temas de interesse do mercado financeiro e de fontes oriundas desse mesmo meio, em detrimento de quaisquer outros agentes sociais. Essa predominância resultou de um processo dividido em duas etapas. Primeiro, o economista do mercado financeiro ingressou no noticiário para oferecer conselhos sobre como os leitores deveriam proteger seu dinheiro da corrosão inflacionária. Envolto na aura de cientificidade a ele conferida pela vertente do cálculo contida nas Ciências Econômicas, esse profissional nada mais fazia do que, subliminarmente, oferecer ao leitor os instrumentos financeiros da instituição em que trabalhava. Foi a partir da adoção do Plano Real, em 1994, que se deu mais claramente a segunda etapa da financeirização, aquela com contornos ideológicos. Com o governo Fernando Henrique Cardoso buscando adotar os princípios neoliberais para levar o Brasil a se beneficiar do enorme fluxo de dinheiro que buscava rendimentos altos pela via do mercado financeiro, muitos bancos adotaram - e outros apenas reforçaram - uma série de estratégias comunicacionais para conquistar os jornalistas, também pressionando por meio do noticiário o governo e o Legislativo a assumir a agenda do neoliberalismo financeiro, com defesa da redução do tamanho do Estado, o fim da intervenção estatal nos processos econômicos, as privatizações, as reformas e a abertura comercial e de serviços financeiros.

Não é raro encontrar leitores que perceberam a financeirização do noticiário econômico nas duas últimas décadas. O que este trabalho procurou fazer foi demonstrar até que ponto essa percepção tinha bases concretas. Para isso, realizou-se um trabalho multimetodológico, com a análise de uma amostra de 14 anos de conteúdo econômico em dois dos maiores jornais gerais do Brasil, Folha de S.Paulo e $O$ Estado de S. Paulo, além de mais de 40 entrevistas (por telefone e pessoais) com economistas do mercado financeiro, jornalistas de redação e de assessorias de imprensa, além de acadêmicos e banqueiros. Verificou-se que temas e fontes defensoras dos princípios financistas, incluindo o governo, predominaram no noticiário do período. As entrevistas também revelaram as estratégias comunicacionais adotadas pelo sistema financeiro para atrair os profissionais de imprensa, dominar o noticiário e impor suas ideias como as únicas cientificamente corretas e irrefutáveis. O noticiário tornou-se um espelho do pensamento único e endossou as reformas econômicas de interesse do capital financeiro tratando-as como de amplo interesse nacional, alijando da 
mídia quaisquer outras ideias divergentes das neoliberais, sobretudo as oriundas dos movimentos sociais e sindicais.

Palavras-chave: jornalismo brasileiro, jornalismo econômico, noticiário econômico, noticiário financeiro, discurso econômico - imprensa. 


\begin{abstract}
PULITI, P. The Financialization of Economic News (1989-2002). 2009. 150s. Thesis (Doctoral) - Escola de Comunicações e Artes, Universidade de São Paulo, São Paulo, 2009.

The economic news content in general Brazilian newspapers began to change as of the second half of the 1980s. Financial market analysts began to substitute traditional sources of information such as businesspeople, major rural producers and, to a far lesser degree, academics and union representatives. The new professionals' qualifications were in accordance with the standards of US neoliberalism, by which developmental forces can only occur when they are freed from the binds of the state and are able to meet and compete in a free market. These professionals won a captive market in general newspapers, leading to a process of financialization. This term, which is practically a neologism, is used here to refer to the predominance in economy news of matters of interest to financial markets and which comes from sources in that area. This predominance has resulted in a process of two stages. Firstly, financial market economists debuted in the news offering advice on how readers could protect their money from inflationary corrosion. Surrounded by the scientific air of calculations involved in Economic Science these professionals did nothing more than offer, subliminally, the financial instruments of the institution in which they were working. It was of the adoption of the Real Plan in 1994 that the second phase of financialization became apparent, which was one with an ideological bent. With the Fernando Henrique Cardoso government seeking to adopt neoliberal principles in order to allow Brazil to benefit from the enormous flow of money seeking high rates of return in the financial markets, a lot of banks adopted - while others simply built on - several communications strategies to win over journalists. Through the news, this put pressure on the government and the legislative to adopt the financial neoliberal agenda, which called for reducing the size of the state, for the end of state intervention in the economy, for privatizations and the reform and opening up of trade and financial services. Readers who have noticed the financialization of the news in the past two decades are no rarity and this work seeks to demonstrate the degree to which the viewpoint has a sound basis. Multi-methodological work has been carried out, with the analysis of 14 years of economy content in two of the largest general newspapers in Brazil: Folha de S.Paulo and O Estado de S. Paulo. There have also been over 40 interviews (by telephone and face-to-face) with financial market economists, newsroom journalists and press officers, as well as with academics and bankers. It was found that themes and sources predominated which favored financial-based principles, including in the government. The interviews also revealed communications strategies adopted by the financial system to attract professionals in the press, in order to dominate the news and impose its ideas as being singularly and scientifically correct and thus irrefutable. The news became a mirror of a single way of thinking and endorsed economic reform of interest to financial capital, treating it as though it were of wider national interest. It unburdened the media of ideas that diverged from neo-liberalism, above all those coming from social and trades union movements.
\end{abstract}

Keywords: Brazilian journalism, financial news, economic news. 


\section{SUMÁRIO}

\section{PARTE UM}

\section{INTRODUÇÃO}

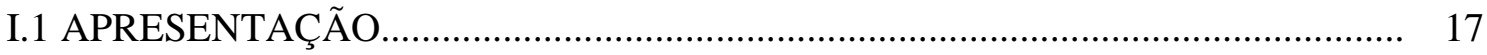

I.2 JUSTIFICATIVAS, OBJETIVOS E PRESSUPOSTOS........................................ 29

I.3 DELIMITAÇÕES DO PROJETO................................................................... 34

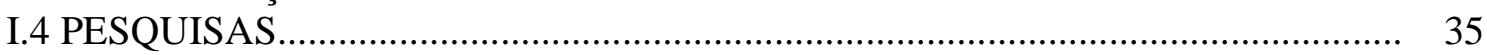

I.5 ESTRUTURA DO TRABALHO ……...................................................... 36

CAPÍTULO 1

REFERENCIAL TEÓRICO - 1

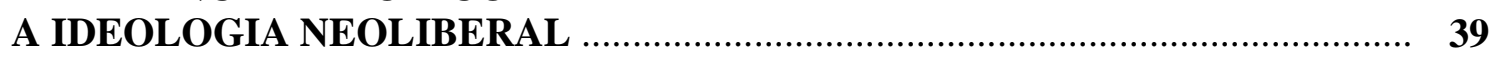

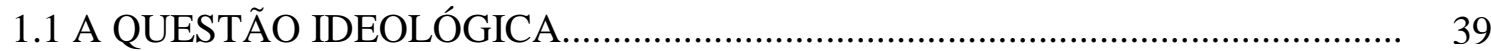

1.1.1 A LEGITIMAÇÃO IDEOLÓGICA DO NEOLIBERALISMO .................... 42

1.2 O NEOLIBERALISMO EM PRÁTICA.................................................................. 44

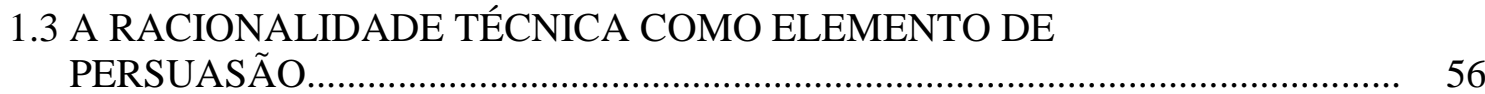

CAPÍTULO 2

REFERENCIAL TEÓRICO - 2

JORNALISMO E GRUPOS DE INTERESSE................................................ 61

2.1 A CONSTRUÇÃO DA NOTÍCIA E A DEFINIÇÃO DA AGENDA

("AGENDA-SETTING").

2.1.1 A HIERARQUIA DA CREDIBILIDADE............................................... 66

2.1.2 O PAPEL DAS ASSESSORIAS DE IMPRENSA..................................... $\quad 70$

2.1.2.1 "MEDIA TRAINING"...................................................................... 72

2.1.2.2 O APELO DA ESPECIALIZAÇÃO, OS CURSOS DE ECONOMIA

E OS PRÊMIOS PARA JORNALISTAS.......................................... 74

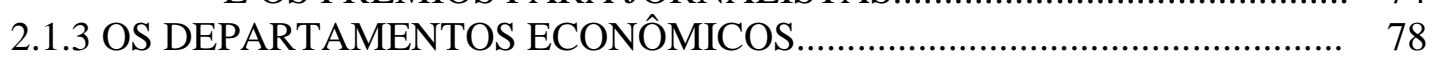

\section{CAPÍTULO 3}

REFERENCIAL TEÓRICO - 3

A FINANCEIRIZAÇÃO DO JORNALISMO ECONÔMICO NO BRASIL - 1... 83

3.1 NELSON WERNECK SODRÉ, UMA RESSALVA........................................... 84

3.2 O INÍCIO DA FINANCEIRIZAÇÃO?.......................................................... 85

3.3 A DUPLA CAMPOS-BULHÕES E O MILAGRE ECONÔMICO........................ 86

3.4 O PLANO REAL E A IMPRENSA.................................................................... 94

3.5 O NOTICIÁRIO EM TEMPO REAL …........................................................... 99 


\section{PARTE DOIS}

\section{CAPÍTULO 4}

A FINANCEIRIZAÇÃO DO JORNALISMO ECONÔMICO NO BRASIL - 2

4.1 PROBLEMÁTICA METODOLÓGICA

4.2 PESQUISAS QUANTITATIVAS - ANÁLISE DOCUMENTAL -

VERIFICAÇÃO DE FONTES DO NOTICIÁRIO ECONÔMICO..

4.2.1 TABULAÇÃO DA ANÁLISE DOCUMENTAL - VERIFICAÇÃO DE FONTES DO NOTICIÁRIO ECONÔMICO

4.2.1.1 COMENTÁRIOS.

4.3 PESQUISAS QUANTITATIVAS - ANÁLISE DOCUMENTAL -

VERIFICAÇÃO DE TEMAS, NÚMERO E CATEGORIAS DE FONTES DAS MATÉRIAS -MANCHETES

4.3.1 TABULAÇÃO DA ANÁLISE DOCUMENTAL - VERIFICAÇÃO DE TEMAS, NÚMERO E CATEGORIAS DE FONTES DAS MATÉRIASMANCHETES

\section{CAPÍTULO 5}

\section{A FINANCEIRIZAÇÃO DO JORNALISMO ECONÔMICO NO BRASIL - 3} PESQUISAS - 2

5.1 ENTREVISTAS DIRIGIDAS

5.1.1 TABULAÇÃO DOS RESULTADOS - ENTREVISTAS DIRIGIDAS.

5.1.1.1 COMENTÁRIOS.

5.2 ENTREVISTAS ABERTAS

5.2.1 A ESCOLHA DOS ENTREVISTADOS

5.2.2 AS ENTREVISTAS TRANSCRITAS.

\section{CAPÍTULO 6}




\section{LISTA DE ILUSTRAÇÕES}

Figura 1. Matéria: exemplo de tema financista.......................................................... 24

Figura 2. Convite para o curso BM\&FBOVESPA de jornalismo................................. 77

Figura 3. Matéria: ministro Fernando Henrique Cardoso recebe editores da imprensa escrita em café da manhã para apresentar o Plano real............................................. 97

Figura 4. Reprodução de tela do $A E$ News................................................................... 102

Figura 5. Reprodução pesquisa AE Projeções sobre Selic na tela do $A E$ News............. 107

Figura 6. Reprodução de pesquisa Focus do Banco Central na tela do AE News........... 108

Figura 7. Reprodução de texto de repórter sobre a pesquisa Focus no AE News........... 109

Figura 8. Exemplo de ficha de levantamento $O$ Estado............................................... 121

Figura 9. Exemplo de ficha levantamento Folha.................................................... 121

Figura 110. Matéria: a "nata" do mercado financeiro internacional critica Brasil......... 176

Figura 119. Matéria: FMI dá a receita para Brasil se desenvolver............................... 273 


\section{LISTA DE GRÁFICOS}

Figuras 10 a 23. Tabulação de fontes da amostra........................................... 123 a 134

Figuras 24 a 109. Tabulação de temas, categoria e número de fontes.............. 138 a 168

Figuras 111 a 118. Tabulação de dados de entrevistas dirigidas ....................... 183 a 187 

PARTE UM 



\section{INTRODUÇÃO}

\section{I.1 APRESENTAÇÃO}

A decisão de realizar um estudo sobre jornalismo econômico nasceu da minha experiência profissional. Trabalho desde 1995 como jornalista de economia na cobertura de mercado financeiro, o que me faz estar sistematicamente imersa no objeto deste estudo, que é o noticiário econômico.

De antemão, é preciso reconhecer que há vantagens e desvantagens em fazer parte do objeto de estudo. O ponto favorável é conhecer intrinsicamente o campo jornalístico em análise, enquanto o desfavorável seria a dificuldade de manter um distanciamento crítico em relação ao problema. O desafio é justamente impedir que a gênese subjetiva do meu interesse, baseada em valores pessoais, interfira nos resultados do estudo. Um dos pais da Sociologia, Max Weber (2006) alertou para a necessidade de o pesquisador se despojar dos valores de forma que a pesquisa não seja apenas a simples reiteração de interesses particulares de um ou outro grupo. Atentar para o distanciamento, portanto, é uma a ser cumprida a cada página deste trabalho.

Escrevo esta parte da Introdução em fevereiro de 2009 para fazer uma ressalva. A ideia de realizar um trabalho sobre financeirização do noticiário surgiu em 2003, bem antes dos primeiros sinais da crise econômica de 2008/2009. Surgiu por conta da percepção de que os jornais só refletiam uma linha de pensamento econômico, a defendida pelos economistas do 
mercado financeiro. O conceito de financeirização que dá luz a este trabalho é, portanto, o predomínio de temas do neoliberalismo financeiro e de fontes ligadas a ele no noticiário econômico. Os temas mais óbvios de mercado financeiro são a) comportamento dos mercados de ações, câmbio e juros; b) quaisquer tipos de investimentos de pessoas físicas ou jurídicas realizados dentro do sistema financeiro; c) medidas do Banco Central que afetam o funcionamento do mercado de capitais, como compra ou venda de moedas estrangeiras, decisões sobre taxas de juros e cobrança de impostos sobre aplicações financeiras. Mas a dimensão da financeirização do noticiário vai muito além de investimentos no sistema financeiro. A financeirização embute a ideologia do neoliberalismo financeiro, o que se traduz em privatizações, desregulamentação, reformas e rigidez fiscal. No noticiário, esses temas aparecem como sendo os mais importantes e fundamentais da agenda econômica nacional.

Entre as pessoas que costumam ler o noticiário com um olhar mais analítico, existe uma certa percepção de que as notícias econômicas refletem a ideologia neoliberal por meio do discurso de representantes do mercado financeiro sempre presentes no noticiário. Este trabalho busca demonstrar até que ponto essa percepção seria algo concreto.

Agora em 2009, com a crise econômico-financeira, o trabalho ganhou uma nova dimensão. O jornalismo parece mesmo ter fracassado em seu papel de ir além da superficialidade do discurso, das ideias e dos acontecimentos, deixando de questionar as supostas verdades científicas de um modelo econômico excludente e consumista. O epicentro da crise atual foi 
o próprio coração do neoliberalismo financeiro, Wall Street ${ }^{1}$. Com os investidores tirando dinheiro em massa das aplicações no mercado financeiro, secou o crédito que havia sustentado os altos níveis de consumo mundial nas últimas décadas, gerando desemprego e desvio de bilionários recursos públicos, inclusive no Brasil, para salvar o sistema do risco sistêmico que a falência de bancos e o enxugamento do crédito representam para toda a economia ${ }^{2}$. Até agosto de 2008, o governo dos Estados Unidos já havia injetado US\$ 2 trilhões no sistema financeiro, mas estimativas de analistas davam conta que o rombo poderia chegar a US\$ 4 trilhões. Instituições como o Citigroup e Bank of America são tidas como insolventes, e o sistema financeiro deve ter US\$10,8 trilhões em "ativos tóxicos", linguagem do mercado para os complexos contratos derivativos feitos junto ao mercado financeiro, de origem duvidosa, com baixa possibilidade de pagamento e pequena aceitação. A crise pode ter desmitificado o poder do livre mercado. O ex-assessor do Tesouro dos Estados Unidos professor Nouriel Roubini e seu colega Matthew Richardson em artigo publicado no Estadão afirmaram, em 15 de fevereiro de 2009: "Como defensores

\footnotetext{
${ }^{1}$ Bairro de Nova York (EUA) onde está localizada a New York Stock Exchange (Nyse), o maior centro financeiro do mundo. A crise no mercado financeiro foi provocada por práticas de empréstimos irresponsáveis que alimentaram o mercado de empréstimos imobiliários de baixa qualidade, os "subprime", nos Estados Unidos. Com o colapso dessas operações, investidores tiveram de se desfazer de suas posições em outros mercados para cobrir as perdas nos Estados Unidos e em outras praças financeiras que negociavam esses contratos. Houve prejuízos, demissões recordes nos Estados Unidos, mas apenas uma falência (o banco Lehman Brothers).

${ }^{2}$ Em 24 de outubro de 2008, jornais do mundo inteiro trouxeram matérias sobre o depoimento de quatro horas que o ex-presidente do FED (Banco Central dos Estados Unidos), Alan Greenspan, deu no dia anterior ao Congresso de seu país. Considerado o "mago" dos mercados, o grande "maestro" e o maior defensor do livre mercado e da auto-regulação das instituições financeiras, com o mínimo de intervenção do Estado, o até então idolatrado Greenspan foi duramente questionado sobre se não teria sido negligente em relação à capacidade do mercado financeiro se auto-regular, o que teria provocado a atual crise. Greenspan admitiu ter errado, mas apenas parcialmente, pois acreditava que as instituições protegeriam os interesses de seus controladores. Vale a pena citar a frase de maior efeito do depoimento: "Aqueles de nós, inclusive eu, que esperávamos que o interesse próprio das instituições de empréstimo protegesse seus acionistas estão em estado de descrença e choque" (Folha, Estado, Gazeta Mercantil, Valor Econômico e O Globo trouxeram matérias sobre o depoimento de Greenspan e a frase citada).
} 
do livre mercado, sentimo-nos como blasfemos ao propor que o governo assuma o controle do sistema bancário americano. Mas não há escolha.”3

No período em que trabalho em jornalismo econômico, que começou em meados dos anos 1990, algumas questões me inquietaram a ponto de motivar esta pesquisa: a primeira foi a lógica bastante peculiar do mercado financeiro ${ }^{4}$, que inúmeras vezes vi comemorar, por exemplo, o aumento do desemprego. Pela lógica financeira, menos pessoas empregadas significa menores pressões inflacionárias ${ }^{5}$. Em termos estritamente de política monetária, inflação menor significa juros básicos mais baixos, o que torna os investidores mais apetitosos por aplicações de maior risco, como as oferecidas pelo mercado financeiro. Preços sob controle, na mesma lógica, são condições essenciais à previsibilidade do comportamento da economia, bem como ao gerenciamento de riscos de investimentos.

\footnotetext{
${ }^{3}$ ROUBINI, N.; RICHARDSON, M. Nem os pessimistas acertaram. O Estado de S. Paulo, São Paulo, 15 de fevereiro de 2009. Caderno Nacional, Opinião, Página 2.

${ }^{4}$ Mercado financeiro é o conjunto formado pelos mercados monetário e de capitais. Abrange todas as transações com moedas e títulos. Neste trabalho, é o conceito que resume o grupo formado por bancos de varejo, de investimentos, corretoras, administradoras de ativos, agências de classificação de risco, consultorias econômicas e entidades representativas, como a Federação Brasileiras de Bancos (Febraban). Algumas vezes poderá ser chamado, apenas para simplificar, somente de mercado.

${ }^{5}$ A título de ilustração do tema, reproduzimos abaixo trecho da pauta do noticiário econômico de 27 de agosto de 2008, de uma agência de notícias:

"EMPREGO/BC: Os números relativos ao mercado de trabalho estão sendo monitorados de perto pelo Banco Central e tendem a ser a chave para as próximas decisões de política monetária, na avaliação de economistas consultados pela reportagem. A preocupação teria base não só no que revelam esses indicadores em si (economia aquecida), mas essencialmente no potencial que eles representam para os segmentos de crédito e consumo, o que pode ser traduzido como inflação futura - esta, sim, variável de análise constante e minuciosa pela autoridade monetária."
} 
$\mathrm{Na}$ prática, a política monetária brasileira, conduzida pelo Banco Central, tem sido fundamentalmente voltada para controlar a inflação ${ }^{6}$, ainda que às custas de juros entre os mais altos do planeta. Juros esses que beneficiam o sistema financeiro. Os bancos, por meio da aquisição dos títulos públicos, emprestam dinheiro ao governo e recebem em troca o pagamento de juros altíssimos.

Também me inquietaram, diversas vezes, reações negativas desse mesmo mercado a declarações de analistas de instituições estrangeiras sobre a economia brasileira. Nesse caso, reação negativa significa fuga de capitais: algum economista faz uma projeção pessimista, e os investidores do mercado financeiro, com medo de perder o que apostaram, vendem o que têm no Brasil e vão buscar refúgio no que é considerado o investimento mais seguro do mundo: os títulos do Tesouro dos Estados Unidos, conhecidos como Treasuries. Em situações graves, as bolsas de valores despencam, a cotação do dólar dispara, a liquidez seca e acaba afetando o setor produtivo, que precisa do credito oferecido pelos bancos para tocar seu caixa e seus investimentos. O governo, refém desse sistema, eleva ainda mais os juros para segurar ou atrair o capital financeiro internacional, que sustenta o crédito.

\footnotetext{
${ }^{6}$ No Brasil, o Banco Central tem sido gerido nos últimos anos por quadros do mercado financeiro, cujo único objetivo é manter a inflação sob controle, dentro de um sistema de metas pré-estabelecidas. Gustavo Franco, Armínio Fraga e Henrique Meirelles, os três últimos presidentes do BC, atuam ou atuaram no mercado financeiro. Gustavo Loyola, antes deles, é hoje sócio de uma destacada consultoria econômica, a Tendências Consultoria Integrada, junto com o ex-ministro da Fazenda, Mailson da Nóbrega. Franco e Fraga são hoje donos de empresas gestoras de fortunas. Meirelles, ainda no governo, foi presidente mundial do Bank Boston antes de assumir a pasta. Fraga trabalhou para o megainvestidor George Soros antes de assumir o Banco Central do Brasil. Tudo isso demonstra que "os bancos centrais, pela sua própria natureza, tendem a favorecer o crescimento do sistema financeiro, pois seus executivos são naturalmente influenciados por outros banqueiros, com os quais se encontram regularmente" (HA-JOON, C. Brasil se atrasa por vontade própria, avalia economista. Folha de S.Paulo, São Paulo, 19 de janeiro de 2009. Caderno A, página 16). A preocupação dos banqueiros centrais não seriam os efeitos maléficos da alta de preços sobre a população e a economia do país, mas sobre os impactos da inflação sobre os investimentos.
} 
Dentro desse quadro mental, lembro-me especialmente de Paulo Leme, um economista brasileiro dos mais ortodoxos, que cursou a mítica escola de Chicago, trabalhou nove anos no Fundo Monetário Internacional (FMI) e atualmente, em Wall Street, é diretor-gerente para Pesquisas e Mercados Emergentes de um ícone capitalista chamado Goldman Sachs, banco de investimentos com interesses bilionários espalhados pelo globo. O trabalho de Leme é entender, analisar e contar ao Goldman Sachs e a seus clientes o que vê na cena econômica mundial. Sua posição lhe confere credibilidade tal, que suas declarações são suficientes para alterar os movimentos dos mercados que negociam ativos brasileiros. As declarações de Leme, mais de uma vez, derrubaram a principal bolsa de valores brasileira, a Bolsa de Valores de São Paulo (Bovespa), e provocaram forte desvalorização da moeda brasileira frente ao dólar.

Nos jornais brasileiros, Paulo Leme é visto como uma fonte de altíssimo nível, e entrevistálo é sinal de prestígio. Mas nunca, nesses anos todos, li qualquer comentário sobre o fato de Leme, ou melhor, o banco que ele representa, ter interesse em influenciar o comportamento das ações, dos juros, dos títulos públicos e de todos os outros instrumentos do mercado. $\mathrm{O}$ que se sabe é que no mercado financeiro, mesmo nos piores momentos de crise, sempre há gente ganhando muito. Não dá para saber se o Goldman Sachs lucrou após alguma declaração de seu economista. Mas, como se costuma repetir na própria área financeira, o capital "não tem pátria". Ele sai de um país e vai para outro em questão de minutos, sempre em busca de melhor remuneração. A esse capital não importa se o alto retorno do investimento é fruto de alguma mazela, de informação especulativa ou de uma robustez fiscal. A única variável que realmente importa é o tamanho do ganho. 
O fato é que o poder que a palavra dos representantes do mercado financeiro tem sobre a formação de expectativas econômicas é muito forte, em especial sobre a saúde econômica dos países em desenvolvimento, alvos mais susceptíveis à opinião dos grandes investidores no mercado de capitais. Os economistas de bancos construíram credibilidade tal, que sempre conseguem espaço no noticiário para traçar cenários sobre o futuro econômico do Brasil. Muitos têm como base de seus cenários as planilhas de projeção. O desempenho econômico futuro de um país é calculado a partir de dados passados que, inseridos em um programa de computador, permitem prever o que acontecerá no futuro: qual será o tamanho da inflação, do Produto Interno Bruto (PIB), da balança comercial, das transações totais correntes, da produção industrial, do nível de emprego, do valor do câmbio e da valorização das ações em bolsa de valores. As planilhas são a bola de cristal contemporânea, e quaisquer dados que venham a fugir do que elas mostram seriam resultado de fórmulas mal aplicadas pelas autoridades. É com essa simplicidade argumentativa que os economistas do mercado financeiro justificam suas projeções que não se confirmam ${ }^{7}$.

\footnotetext{
${ }^{7}$ O conhecido jornalista econômico brasileiro Luiz Nassif, quando colunista da Folha de S.Paulo, popularizou em suas colunas a expressão "cabeças-de-planilha" para se referir aos economistas ou analistas de bancos e consultorias, cuja capacidade de prever fenômenos econômicos está baseada na combinação de uma série de variáveis numéricas colocadas nas planilhas de computador ou em equações e regressões econométricas. Mas as planilhas jamais supuseram, por exemplo, que em 2007 instrumentos desse mesmo mercado financeiro lastreados em créditos de pagamento duvidoso de hipotecas norte-americanas iriam sucumbir à inadimplência e arrastar com eles o sistema mundial de crédito, provocando falências e desemprego em todo o mundo numa espécie de efeito dominó.
} 
REUNIÃO DO BID Assessor divulga pesquisa em que $63 \%$ dos entrevistados afirmam que privatizações na região não foram boas Reformas nãofazem AL crescer, diz estudo

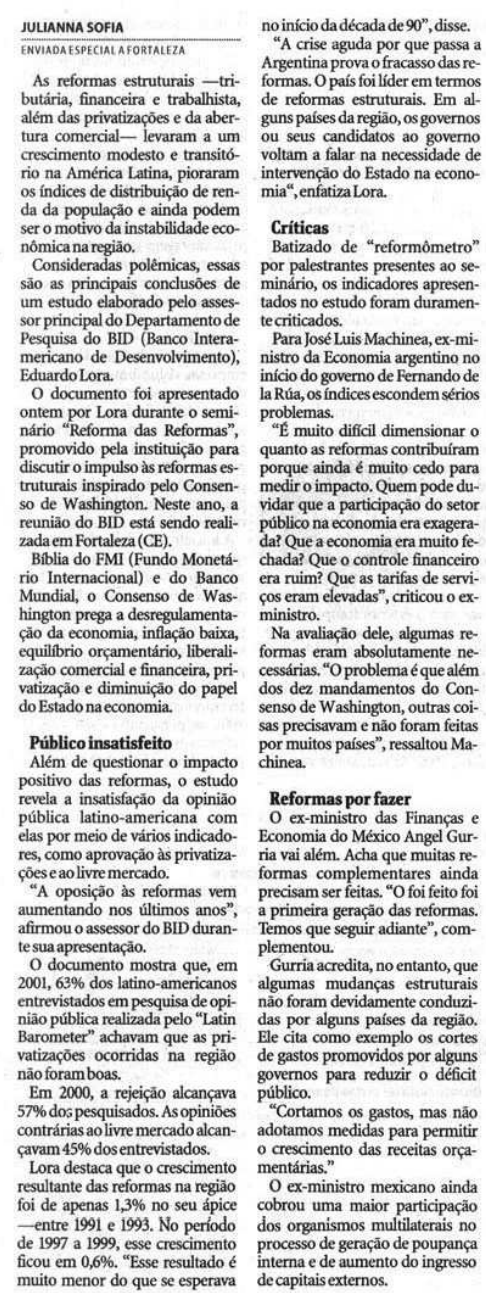

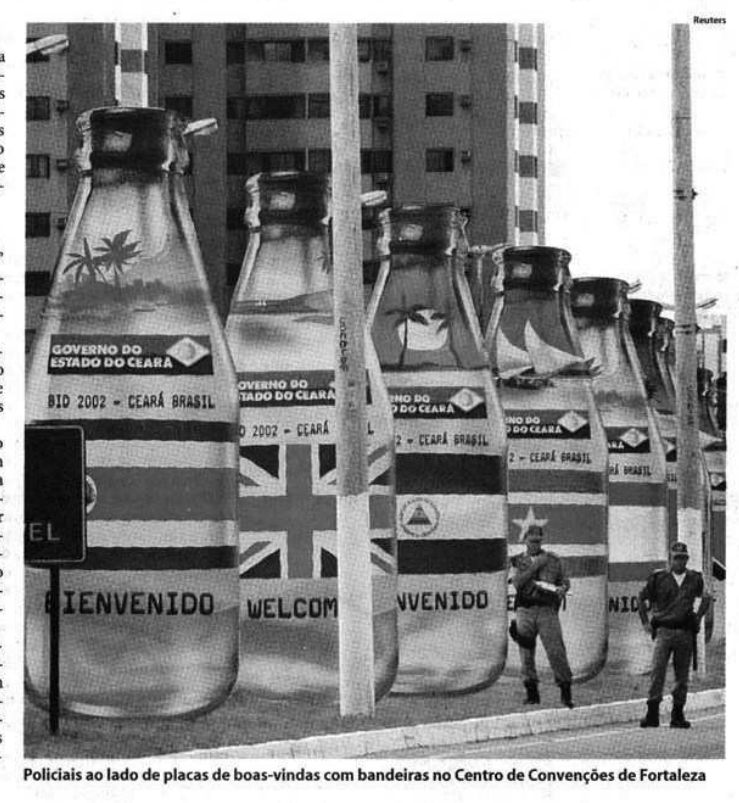

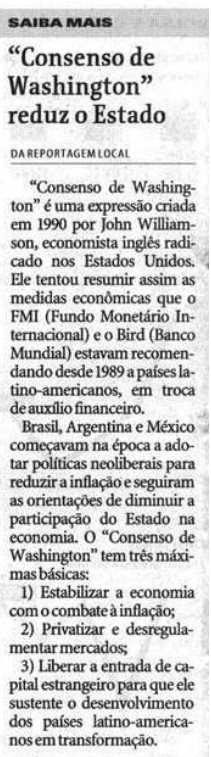

\section{FHCfala hoje sobre o América do Sul quer desafiodemocrático US\$ 40 bi em 8 anos}

Figura 1. Matéria diz que reformas não fizeram América Latina crescer porque foram mal feitas (FSP, 10/03/2002). Reprodução fotográfica pelo Acervo do Estado de São Paulo, abril de 2009.

As projeções derivam da econometria, a principal vertente quantitativa das Ciências Econômicas, que utiliza métodos estatísticos e funções matemáticas para traduzir em números os objetos de estudo econômico. Por isso, têm importante papel na definição de expectativas. Só que o uso abusivo de projeções como principal fundamento da economia, 
como fazem muitos financistas, ignora as dinâmicas da política e do comportamento social como determinantes dos processos econômicos (ARAÚJO, 1998; PAULANI, 2005; DUPAS, 2005; ORTIZ, 2006). As projeções não são o problema, mas o mau uso que se faz delas. Embora os métodos estatísticos sejam os melhores instrumentos disponíveis para se obter projeções, os números são utilizados sem visão de conjunto, sem reflexão, tornando o debate econômico superficial.

O fato é que a relação entre as projeções e as ciências exatas ajudou a construir a credibilidade dos economistas de mercado frente aos jornalistas. Isso porque a economia, numa visão abertamente econometrista, é sintonizada com as matemáticas. E a sociedade está acostumada a ouvir e repetir que os números não mentem jamais. Ao mesmo tempo, a autoridade e o prestígio dos métodos quantitativos estão diretamente relacionados à ideia de objetividade e do conhecimento impessoal (PORTER, 1995: ix), característicos do saber científico moderno. A aparente neutralidade e a desideologização das métricas econômicas tornaram os economistas do mercado fontes muitos respeitadas entre os jornalistas, já que a ideologia do jornalismo também se baseia nos mesmos padrões de neutralidade, objetividade e independência política.

Para a imprensa, tudo isso significa que ao assumir e defender uma única forma de ver o processo econômico, ela minou qualquer possibilidade de debate de ideias, desequilibrando o jogo de interesses entre os diferentes grupos sociais e fugindo dos pilares democráticos que a sustentam como representante da verdade. O jornalismo tem respaldado como única correta a visão de mundo do capitalismo financeiro, que para ser lucrativo precisa impor globalmente o seu receituário político-econômico de Estado mínimo, privatizações e 
desregulamentação, em que as leis de oferta e procura prevaleceriam como fator único de regulação das sociedades.

Em The Great Clash, um dos mais famosos livros sobre os antecedentes da crise econômica de 1929 iniciada nos Estados Unidos, Galbraith (1980:64) já havia destacado o importante papel da imprensa na formação de expectativas falsas. Segundo ele, a grande maioria das revistas e jornais da época (segunda metade da década de 1920) nos Estados Unidos mostrava a alta do mercado acionário com admiração e sem qualquer alarme, apesar de fortes sinais de deterioração e especulação no sistema indicarem a proximidade de uma derrocada na alta das ações. A exceção a esse otimismo só era vista em jornais especializados. No verão de 1929, o mercado financeiro não apenas dominava o noticiário, mas a cultura norte-americana. Mesmo quando as bolsas começaram a despencar, houve todo um movimento na imprensa para manter o mercado de capitais em alta. Os operadores e economistas do mercado financeiro continuaram "em seus templos", sempre muito procurados pelos jornalistas, até que eventualmente o impacto da perda de dinheiro na economia real tornou insustentável continuar a defender o mercado acionário.

Se o jornalismo encontra nos economistas de mercado uma visão aparentemente neutra e despolitizada dos fenômenos econômicos, para os agentes de mercado a colaboração com os jornalistas tem um duplo significado: atrair clientes para suas instituições e influenciar na agenda político-econômica nacional. Os economistas do mercado financeiro muito provavelmente construíram seus espaços no noticiário para ganhar legitimidade perante 
outros agentes da sociedade como detentores do único modelo científico capaz de beneficiar à toda sociedade igualmente. Mas também - e talvez sobretudo - para dar opiniões que batem diretamente na formação de expectativas do próprio mercado, repicam em Brasília, onde provocam reações e buscam respostas, e ainda chegam aos leitores dos jornais, entre os quais potenciais clientes para o sistema financeiro.

Chernavsky (2008:21), ao pesquisar os determinantes das "excepcionalmente elevadas" taxas de juros no Brasil, concluiu que o Banco Central determina quase que totalmente suas ações de acordo com as expectativas dos mercados financeiros. Embora concorde que os mercados exerçam papel determinante como mecanismo de transmissão da política monetária, o autor aponta que "ao seguir" os mercados, "o Banco Central se torna particularmente vulnerável às exigências de um grupo de lógica desestabilizadora - já que o mercado é propenso a bolhas especulativas, caprichos e crises financeiras - e com interesses próprios bem definidos." Tem sido assim há mais de 14 anos. O controle da inflação a partir da implantação do Plano Real de estabilização econômica em 1994 foi feito em bases liberalizantes, ao custo de uma explosão da dívida pública por conta dos juros altos. O aumento do endividamento do Estado concedeu enorme poder de chantagem aos bancos, que financiam essa dívida e, assim, controlam as políticas econômicas do Estado (NOBRE, 2008).

A financeirização do noticiário teve ainda outro efeito, desta vez mais diretamente sobre o leito. Levou a informação econômica para longe do leitor comum. Os cadernos de economia são os primeiros a serem descartados, inundados por uma terminologia muito específica, que nada diz ou acrescenta aos não-iniciados, como bolsa, câmbio, captação, 
mercado financeiro, swap, derivativos, risco-país, bônus, superávit primário, superávit nominal zero, equilíbrio fiscal, déficit em conta corrente, fluxo cambial e balança comercial. Pesquisa realizada em 2003 pela Ipsos-Marplan, divisão da Ipsos Brasil, mostrou que entre aqueles que haviam lido Folha de S.Paulo, $O$ Estado de S.Paulo ou $O$ Globo nos sete dias anteriores à pesquisa, apenas $25 \%$ haviam lido o noticiário econômico ${ }^{8}$. Os outros $75 \%$ deixaram de lado os cadernos de economia porque não entendiam o que estava escrito ali. Não viram relação do noticiário com seus cotidianos. Outro dado: as notícias econômicas ocupavam a $12^{\mathrm{a}}$ posição na lista dos temas preferenciais, de um total de 18, entre os assinantes desses mesmos diários. Um tema tão presente no dia-a-dia dos cidadãos e importante para a construção da cidadania só desperta o interesse de poucos. Ortiz (2006) acredita inclusive que a linguagem hermética e de difícil compreensão para o cidadão não-economista seja uma forma de dominação social. A terminologia do mercado criou uma aura sacerdotal em torno da economia, ao mesmo tempo em que a falta de clareza do discurso econômico inibiu questionamentos. Tudo o que parece difícil parece também científico, e a ciência não admite questionamentos por quem é leigo. Como a mídia é o espaço estratégico de formulação de crenças e consensos, a fé que a sociedade deposita nas palavras dos representantes ${ }^{9}$ do mercado financeiro deve-se em grande medida aos jornalistas (ORTIZ, 2006:12). Embora o jornal não seja um documento econômico no sentido mais estrito, ele divulga o discurso econômico. Assim, analisar o conteúdo do

\footnotetext{
${ }^{8}$ Os dados foram repassados à pesquisadora pela assessoria de imprensa da empresa.

${ }^{9}$ Uma ressalva: nem todos os "economistas" do mercado financeiro são graduados em economia. Muitos são engenheiros, físicos e administradores de empresas que trabalham como analistas de temas econômicos. Para simplificar, serão chamados de economistas, analistas ou estrategistas.
} 
noticiário também é indispensável para desvendar, por trás de enunciados objetivos e neutros, interesses específicos e prescrições dissimuladas de políticas sociais e econômicas.

Os jornais brasileiros de maior circulação têm circulação relativamente pequena para sua importância, da ordem de 300 mil a 400 mil exemplares diários, chegando apenas à elite da elite brasileira. Somando-se, por exemplo, prefeitos, presidentes de Câmaras e vereadores de cinco mil municípios brasileiros, mais presidentes de grandes empresas e bancos e suas diretorias, mais deputados federais e estaduais e presidentes e diretores de autarquias, chega-se a mais ou menos esse número de leitores (2008 informação pessoal $)^{10}$. Significa dizer que os leitores desses jornais são nomeadamente as elites e seus quadros, onde está grande parte dos formadores de opinião. Essa mesma elite é também personagem de muitas das notícias. As fontes estão falando e lendo sobre elas mesmas, e a notícia é o que se passa, afeta ou atinge a elas, e não interesses sociais mais abrangentes, que as elites desconhecem. A definição da agenda nacional parte das elites, o noticiário econômico hermético é compreendido apenas pelas elites. O jornalismo se justifica em nome do interesse público, mas esse mesmo público não participa dele. É apenas um espectador do que ocorre nas elites (KOVACK; ROSENSTIEL, 2004). O jornalismo atual, o econômico em particular, parece estar muito distante dos ideais democráticos e do debate de ideias que o legitimaram e lhe deram credibilidade.

\section{I.2 JUSTIFICATIVAS, OBJETIVOS E PRESSUPOSTOS}

\footnotetext{
${ }^{10}$ Informação fornecida por Kucinski em São Paulo, em entrevista à autora em 2008.
} 
O trabalho foi concebido para contribuir com a formação de jornalistas que questionem ideias estabelecidas, técnicas consagradas e pensamentos paradigmáticos, dentro do pressuposto de que a universidade deve formar cidadãos conscientes, qualificá-los para o mercado de trabalho e criar profissionais que enfrentem os desafios postos pelas fronteiras da técnica e do conhecimento ${ }^{11}$.

O pilar do trabalho é a ideologia autoprofessada pelo jornalismo, segundo a qual a imprensa é elemento fundamental da democracia, e o jornalismo é um serviço público em que as notícias são o alimento que os cidadãos precisam para exercer seus direitos democráticos (TRAQUINA, 2004:126). Porém, quando se pensa o jornalismo como peça-chave para a democracia, depara-se com uma contradição. A prática jornalística é sustentada por um ethos, segundo o qual é por meio da imprensa que a sociedade tem acesso à verdade dos acontecimentos e das políticas, podendo assim tomar decisões que resultem de debate. A legitimidade da qual a imprensa desfruta diante da sociedade acaba também por autenticar aqueles que falam no noticiário. Mas o forte caráter autoreferencial do jornalismo revela que o noticiário econômico no Brasil é dominado pelo discurso das elites, que têm interesses diferentes dos da vasta maioria da população. A elite financeira, que está no cerne deste estudo, tem um diferencial importante frente a outros grupos da elite brasileira: sua capacidade de se organizar, utilizando a mídia em larga escala para se transformar um porta-voz de toda a sociedade. Demonstrar como o grupo financeiro valeu-se da imprensa para se tornar suposto porta-voz de interesses gerais está dentro do objetivo maior deste

\footnotetext{
${ }^{11}$ Palavras emprestadas do professor José Arthur Giannotti. GIANNOTTI, J.A. Deficientes Devem Ter Vagas no Ensino?. O Estado de S. Paulo. São Paulo, 1 de maio de 2009. Caderno Nacional, página 8.
} 
trabalho, que é contribuir para a construção de visões mais críticas sobre a prática jornalística brasileira

O noticiário econômico tem sido dominado nos últimos anos pelo chamado discurso do pensamento único ou hegemônico. Trata-se do predomínio de uma visão de mundo que traduz os interesses neoliberais, representados pelo sistema financeiro. O neoliberalismo, como doutrina, é um corpo de regras que defende o livre mercado acima de quaisquer outros interesses. Para que o mercado esteja no controle da vida pública, é necessário que o Estado esteja ausente, algo que se consegue com privatizações, desregulamentações e rígido controle fiscal (RAMONET, 1995).

No Brasil, a retórica neoliberal conquistou os jornais em parte por influência da imprensa estrangeira, mas em escala muito maior por conta do discurso estrategicamente preparado e veiculado por banqueiros, executivos de empresas, economistas e acadêmicos alinhados com a forma neoliberal de ver o mundo, que para eles é a única capaz de promover crescimento econômico sustentável e distribuição da renda, colocando fim às desigualdades sociais de forma científica e apolítica.

Faria (1994: 130-131) mostrou que a mídia endossou o programa de privatizações brasileiro, iniciado nos anos 1990, dentro da perspectiva de melhora das contas públicas e da redução do tamanho do Estado. O noticiário econômico não criticou os valores nem os critérios de avaliação das estatais adotados pelo Banco Nacional de Desenvolvimento 
Econômico e Social (BNDES) e sequer mencionou a ausência de política industrial no contexto da privatização. Na verdade, a privatização tornou-se palavra mágica, mais um slogan sem aprofundamento de discussões do que uma ideia debatida amplamente. À mídia coube transformar o Programa Nacional de Desestatização (PND) em solução para os males nacionais, dando respaldo teórico a grupos de pressão interessados na venda de bens públicos. A imprensa concedeu espaço enorme ao então presidente do BNDES, Eduardo Modiano, responsável pelo PND, sem sequer questionar se haveria queima do patrimônio público. Os jornais brasileiros apenas endossaram o discurso privatista de governos com inclinação neoliberal, segundo o qual o Estado mínimo seria o pilar central da modernização econômica. O que se criticou ainda menos foi o fato de o governo brasileiro ter decidido destinar parcela importante dos recursos da venda de empresas públicas para pagar dívidas, mas não para investir em áreas sociais como saúde, educação, habitação e saneamento. No episódio da privatização, a imprensa exerceu a função de auxiliar a política neoliberal tal o empenho em aprovar o PND.

A imprensa brasileira se rendeu ao discurso da "Tina" ("There is no alternative"— não há alternativa) que caracteriza o pensamento único. E ao fazê-lo, sustentou a visão de que existe só uma política econômica. Economistas das mais variadas filiações ideológicas defendem hoje que não existe mais política econômica de esquerda, de direita ou de centro. Mas sim a política certa, aquela tecnicamente fundamentada e neutra. Contra ela, existiria apenas a política errada, irresponsável, utópica, obsoleta, não-científica, ingênua, inflacionista e populista (PAULANI, 2008:17). No campo das ideias neoliberais, são intocáveis o ajuste fiscal duro, o juro real elevado, a política monetária contracionista, o câmbio flutuante e, sobretudo, a livre movimentação de capitais. Se só há uma política 
macroeconômica cientificamente comprovada, um governo responsável, qualquer que seja sua filiação ideológica, deveria adotá-la. Qualquer pensamento dissonante desse é estigmatizado. Não há alternativa.

Obviamente há pensamentos dissonantes do hegemônico. Para Dupas (2005), ao contrário do que se autoprofere, o neoliberalismo financeiro é excludente e usurpador, beneficiando apenas uma pequena parcela da sociedade, que seria a própria elite financeira e a classe empresarial que tem dinheiro para aplicar no mercado de capitais. Só que para ditar as regras econômicas e não serem vistos como meramente usurpadores, os financistas precisam ser vistos como agentes legítimos de toda a sociedade. Para isso, precisaram ser legitimados pela imprensa, pois é ela que organiza e apresenta a informação à sociedade. $\mathrm{O}$ que o jornalismo veicula tem impacto direto na forma como o mundo é visto e entendido. Por isso os jornalistas são alvo de estratégias comunicacionais.

A conquista da mídia pelos financistas aconteceu a partir da adoção de uma série de estratégias operadas junto aos jornalistas, que vão desde a formatação de um discurso persuasivo com bases supostamente científicas até os inúmeros contatos pessoais, com telefonemas e emails diários, sugestões de pautas exclusivas, além de uma ampla oferta de estudos e levantamentos. Os economistas do mercado financeiro estão sempre disponíveis para entrevistas. E em nome de suas instituições convidam com frequência os jornalistas para almoços e jantares, além de oferecer ingressos para eventos culturais e esportivos. Até prêmios para reportagens de finanças entram na agenda dos jornalistas. 
O trabalho procura ir além do discurso manifesto nos jornais para mostrar como estratégias de comunicação foram concebidas e colocadas em prática, financeirizando o noticiário econômico. As pesquisas buscam mostrar:

a) O início e a consolidação da financeirização do noticiário econômico de 1989 a 2002 dos governos José Sarney (1985-1990), Fernando Collor de Mello (1990-1992), Itamar Franco (1992-1995) ao fim da chamada era FHC (Fernando Henrique Cardoso, 19952003), quando as principais estratégias dos bancos foram colocadas em prática, desenhando o tipo de jornalismo econômico que se pratica hoje no País;

b) As estratégias com as quais os agentes do mercado financeiro construíram seus espaços na imprensa, desde o papel das assessorias de imprensa e dos media training até a criação e valorização dos departamentos econômicos nas instituições financeiras, passando pela relevante atuação dos informativos em tempo real na tarefa de alçar profissionais do mercado financeiro à categoria de fontes.

Uma ressalva. Há diferenças marcantes entre o trabalho dos repórteres, que cumprem a rotina diária da produção de notícias, e dos colunistas de economia, que fazem interpretação dos fatos econômicos e trabalham com as informações de bastidores. Esta pesquisa se dedica exclusivamente a analisar a construção da notícia no dia a dia das redações e não nas salas dos colunistas.

\section{I.3 DELIMITAÇÕES DO PROJETO}


O objeto da pesquisa, de maneira ampla, é o noticiário econômico. Mas não aquele dos grandes jornais econômicos impressos, como Gazeta Mercantil e Valor Econômico. O trabalho analisa os cadernos de economia de dois dos três maiores jornais gerais do Brasil, a Folha de S. Paulo e O Estado de S. Paulo, voltados para públicos não-especializados.

A escolha dos jornais não foi aleatória. Nasceu da hipótese de que o mercado financeiro se serve dos jornais gerais, de maior circulação, em sua estratégia para definir a agenda nacional e atrair clientes do varejo, além de ter acesso mais amplo a formadores de opinião para além do círculo econômico. Enquanto Folha e Estado têm cadernos de economia, o Globo, do Rio de Janeiro, outro grande jornal brasileiro, tem páginas dedicadas, mas não um caderno exclusivo de economia. Por isso não entrou na amostra.

O recorte temporal, entre 1989 e 2002, engloba os primeiros governos civis que sucederam ao regime militar, conforme descrito acima, período que coincidiu com a ascensão do capital financeiro como (auto-proferida) fonte de crescimento do Brasil.

\section{I.4 PESQUISAS}

Para cumprir com os objetivos de mostrar que o noticiário brasileiro se financeirizou e como se deu a construção do discurso neoliberal na imprensa brasileira, quatro pesquisas foram realizadas. 
As duas primeiras foram levantamentos quantitativos de conteúdo editorial a partir de uma amostra dos dois jornais no período 1989-2002. Verificou-se a prevalência fontes e de temas de interesse do sistema financeiro noticiário econômico, além da pluralidade e transparência das matérias. Serão detalhadas no Capítulo 4.

No Capítulo 5 estão as outras duas pesquisas. Primeiro, as entrevistas com perguntas específicas realizadas com profissionais do mercado financeiro. Geraram um resultado também numérico, mas já permitem associar os resultados a um conteúdo social. O objetivo foi mostrar quais instituições financeiras tinham assessorias de imprensa, ofereceram media training, quais criaram departamentos de economia e como seus profissionais se relacionam com os jornalistas. Esses elementos denotam o objetivo de inserção na mídia e de criação de imagem junto aos leitores.

Os resultados numéricos das pesquisas só conseguiram ganhar um sentido social quando foram transformados em elementos do cotidiano de pessoas envolvidas com o mercado financeiro e com os jornalistas, o que aconteceu no segundo conjunto de entrevistas do Capítulo 5. Fazer a ligação entre o mundo dos números e o das pessoas talvez tenha sido o grande desafio metodológico deste trabalho. Assim, as entrevistas com jornalistas, economistas, banqueiros e acadêmicos.

\section{I.5 ESTRUTURA DO TRABALHO}


O primeiro capítulo traz o referencial que dá suporte teórico ao estudo, trazendo questões ideológicas e os interesses por trás do discurso neoliberal que a imprensa reflete. É também nesse capítulo que se aborda o papel da racionalidade como instrumento-chave da linguagem persuasiva que caracteriza o discurso do neoliberalismo financeiro.

Situado o plano ideológico neoliberal, o segundo capítulo desenvolve a abordagem teórica adotada na discussão do jornalismo e seu papel na democracia, como legitimador de fontes e de enquadramento de realidades. É nesta parte do trabalho que se vai discutir a construção do noticiário e o papel da imprensa na definição da agenda nacional, além da importância que os diversos agentes sociais conferem ao espaço midiático. O capítulo mostra que aparecer na mídia exige esforço e investimento.

O Capítulo 3 traz uma breve história do jornalismo econômico atual no Brasil, enfatizando o momento histórico da financeirização e o papel que os noticiários em tempo real tiveram na definição das pautas e na apresentação das fontes do mercado financeiro aos jornais.

Os capítulos 4 e 5 trazem as pesquisas, descrevendo metodologia, levantamentos, tabulação e comentários. Os dados quantitativos foram transformados em imagens para melhor visualização do que eles representam. E ao final de cada capítulo foi escrito um comentário, uma espécie de conclusão sobre o que cada pesquisa mostrou.

O Capítulo 6 é a conclusão do trabalho, integrandos os achados e buscando fazer o diálogo entre o referencial teórico e as pesquisas realizadas. 
O trabalho tem quatro Anexos:

a) Pequeno levantamento de imagens de matérias do período analisado, tiradas durante a pesquisa de conteúdo editorial e ajudam a ilustrar na prática a financeirização do jornalismo econômico;

b) Exemplos de relatórios de bancos e de consultorias enviados para os jornalistas, que servem como ideias para matérias;

c) Exemplos de comunicados (releases) de assessorias de imprensa sugerindo fontes; oferecendo cursos e prêmios aos jornalistas;

d) Exemplo de publicidade de empresa de media training. 


\section{CAPÍTULO 1}

\section{REFERENCIAL TEÓRICO - 1}

\section{A IDEOLOGIA NEOLIBERAL}

Este capítulo apresenta a linha teórica escolhida para demonstrar:

a) A ideologia neoliberal e sua ligação com o sistema financeiro;

b) O papel da racionalidade matemática como elemento legitimador da doutrina econômica neoliberal-financeira como única correta.

\subsection{A QUESTÃO IDEOLÓGICA}

Os discursos representam uma forma de narrar o mundo. Hoje, a imprensa é uma das principais, se não a principal, organizadora e distribuidora de discursos para a sociedade, não importa por qual mídia. Diante da infinidade de informações geradas globalmente, é ela que coleta fatos e define o que deve ou não chegar até as pessoas na forma da narrativa noticiosa. Como a imprensa é socialmente legitimada pelas bases democráticas que a sustentam, acaba por definir as agendas das cidades, dos países e do mundo. É preciso levar em conta, no entanto, que os discursos são poderes em operação e encerram projetos de 
controle. Sendo assim, o discurso manifesto pela imprensa constrói visões de mundo, tornando o jornalismo alvo prioritário da ação de grupos de interesse em busca de legitimação e apoio para suas ideias, apesar de a imprensa se auto-proferir como objetiva e imparcial (GOMES, 2003:45).

Toda classe que aspira à dominação.[...] deve conquistar primeiro o poder político para apresentar, por sua vez, o interesse próprio como sendo o interesse geral.[...] Por outro lado, o embate prático desses interesses particulares, que se chocam realmente com os interesses coletivos e ilusoriamente coletivos, torna necessária a intervenção prática e o refreamento por meio do interesse 'universal' ilusório sob forma de Estado.

Os pensamentos da classe dominante são também, em todas as épocas, os pensamentos dominantes; em outras palavras, a classe que é o poder material dominante numa determinada sociedade é também o poder espiritual dominante. A classe que dispõe dos meios da produção material dispõe também dos meios da produção intelectual, de tal modo que o pensamento daqueles aos quais são negados os meios de produção intelectual está submetido também à classe dominante. Os pensamentos dominantes nada mais são do que a expressão ideal das relações materiais dominantes; eles são essas relações materiais dominantes consideradas sob forma de ideias, portanto a expressão das relações que fazem de uma classe a classe dominante; em outras palavras, são as ideias de sua dominação. (MARX e ENGELS, 2002:48).

Seguindo a linha de Marx e Engels, o pensamento econômico dominante é a manifestação da classe dominante. No caso em questão, a classe dominante atual é a elite financeira, que para se legitimar como detentora da verdade econômica busca definir a agenda nacional e convencer a sociedade de que seus interesses objetivam o bem comum. Apesar de ser amplamente aceito que as elites vigentes determinam as ideologias, questionar $\mathrm{o}$ pensamento dominante é fundamental para a construção de visões críticas sobre as diversas 
políticas. Falando especificamente da elite financeira, Dupas (2005) lembra que ela busca legitimação, inclusive via imprensa, até para não ser classificada como artificial, fraudulenta, excludente e protetora dos jogadores do cassino do mercado financeiro ${ }^{12}$.

O que se questiona é por que a imprensa aceitou de forma tão acrítica um modelo de desenvolvimento erguido sobre as premissas frágeis do crédito farto, dos ganhos fáceis do mercado de capitais e do enxugamento do Estado. A predominância do discurso neoliberal financista na imprensa não obedeceu a um processo abrangente e aberto de formação de consensos, mas foi construída a partir de uma série de estratégias bem delineadas de comunicação. A doutrina neoliberal apresenta-se embalada por um aparato conceitual retórico de respeito no trato à coisa pública, na necessidade de transparência, austeridade e gestão fiscal responsável. São elementos discursivos de forte apelo social e moral para sociedades marcadas pela corrupção, como as latino-americanas. Bem sucedido, o arcabouço conceitual tornou-se tão intrinsicamente inserido no senso comum que passou a ser inquestionável (HARVEY, 2007:5). Dentro dos princípios de fiscalizar governos, a imprensa não poderia dar as costas a uma doutrina econômica que soa moralmente tão correta. O que nunca se questiona é que por trás desse receituário está a preocupação dos financistas com a capacidade de governos pagarem suas dívidas, bem como acabar com a influência do poder público sobre o setor privado.

\footnotetext{
${ }^{12}$ Apenas entre setembro e outubro de 2008, os governos de Estados Unidos e da União Europeia investiram no sistema financeiro o equivalente a $11 \%$ do PIB mundial para salvar bancos e instituições, que perderam dinheiro com o fracasso de operações financeiras de alto risco com créditos hipotecários de liquidação duvidosa nos Estados Unidos, a chamada crise "subprime", que se tornou sistêmica.
} 


\subsubsection{A LEGITIMAÇÃO IDEOLÓGICA DO}

\section{NEOLIBERALISMO}

O neoliberalismo é a ideologia do capitalismo financeiro. Trata-se de um conjunto de práticas de política econômica, segundo as quais a melhor forma de se atingir o bem-estar humano é a liberalização das capacidades individuais - ideia herdada da teoria liberal ou clássica, de mercado autoregulável ("laissez-faire”) (POLANYI, 1980:142) ${ }^{13}$ - , dentro de um marco institucional caracterizado por direitos muito bem assegurados de propriedade privada e livre mercado. O papel do Estado seria o de assegurar o arcabouço institucional para que tais práticas funcionassem adequadamente (HARVEY, 2007:2).

O modelo neoliberal se autoqualifica como racional, neutro e abrangente, sem influências políticas e partidárias. A base da doutrina retoma ideias de que valores centrais da civilização, como a dignidade humana, também seriam naturalmente organizadas pela "mão livre do mercado"14, que Adam Smith (1723-1790) propunha no fim do Século XVIII

\footnotetext{
${ }^{13}$ A teoria econômica clássica, da qual surgiu o liberalismo, serviu de substrato ideológico para as revoluções anti-absolutistas que sacudiram a Europa, especialmente Inglaterra e França, ao longo dos séculos XVII e XVIII, e também para a luta pela independência dos Estados Unidos (SANDRONI, 1985:241). Seu surgimento correspondeu aos anseios da burguesia, que consolidava seu poder econômico contra o absolutismo monárquico e o poder religioso. A espinha dorsal dessa teoria, o princípio do "laissez-faire", se estruturou no bojo do combate à ação econômica do Estado (POLANYI, 1980). Como doutrina definitiva, ganhou forma nos trabalhos de John Stuart Mill, Adam Smith, David Ricardo e Thomas Malthus.

${ }^{14}$ Smith, em A Riqueza das Nações, publicado pela primeira vez em 1776, observou que o comportamento dos agentes econômicos atendendo cada um a seu próprio interesse, mas coordenados pelo mercado, levaria a uma espécie de "ordem natural" com um sistema de preços que harmonizaria o interesse de todos (a mão invisível). Essa hipótese deu origem ao homo oeconomicus, que mais tarde seria transformado em um ser racional, em busca permanente do ganho máximo (apud POLANYI, 1980).
} 
dentro do conceito do Economia Política. Para o neoliberalismo, qualquer forma de intervenção do Estado ameaçaria esses valores de liberdade ${ }^{15}$ (GODBOUT, 1998).

Deve-se considerar, no entanto, que por mais científico que o aparato conceitual possa parecer, não existem doutrinas econômicas técnicas ou neutras, só a defesa de interesses (ARAÚJO, 1998; DUPAS, 2005; HARVEY, 2007; ORTIZ, 2006). Na teoria, o setor privado, resumido na endeusada palavra "mercado", é aberto à concorrência, o que o tornaria muito mais eficiente (segundo a doutrina se autoprofere) do que o Estado. $\mathrm{O}$ mercado seria capaz de se autoregular sem interferências políticas, apenas pelas leis de oferta e demanda, permitindo que as pessoas escolhessem o que fosse melhor para elas. Na prática, porém, o neoliberalismo quer o setor privado livre das amarras do Estado. Essa liberdade permitira o livre fluxo de dinheiro e de mercadorias pelo globo, sem que leis restringissem os objetivos do capital de busca da maior remuneração no mercado de capitais.

Em termos históricos, a fé no poder do livre mercado de resolver todos os desequilíbrios fora retomada (na forma de um novo liberalismo) nos anos 1950, como o centro das ideologias das grandes corporações e dos banqueiros, uma elite econômica que se consolidou com a recuperação da economia dos Estados Unidos após a crise de $1929^{16}$

\footnotetext{
${ }^{15}$ Em artigo recente, a ex-secretária de Estado dos Estados Unidos (de 1997 a 2001) Madeleine Albright retomou o discurso da justiça, referindo-se a seu país como o grande defensor de valores como o otimismo, a perseverança, a defesa da justiça, o compromisso com a liberdade e o desejo de paz. É preciso, disse em carta aberta aos candidatos à sucessão de George W. Bush, que se recupere a confiança e a solidez na disciplina financeira (ALBRIGHT, M. A Dura Tarefa de Resgatar a Credibilidade do País. O Estado de S. Paulo. São Paulo, 5 de outubro de 2008. Caderno Nacional, página 10).
}

${ }^{16}$ A consolidação do capitalismo criou monopólios e, no final do século XIX, as contradições do sistema econômico se mostraram na forma de concentração de renda e propriedade. As contradições se acentuaram, e 
(GRUN, 2005). Mas para se tornarem amplamente aceitas, as ideias neoliberais ${ }^{17}$ precisaram de um ciclo de apoio bem maior. Precisaram da imprensa e de acadêmicos, que difundiram essas ideias a todas as classes de políticos, funcionários públicos, trabalhadores e estudantes (LEBARON, 2000; ORTIZ, 2006).

\subsection{O NEOLIBERALISMO EM PRÁTICA}

A receita neoliberal diz que os cortes de gastos públicos, as privatizações, a "flexibilidade" das leis trabalhistas e a abertura da economia ao livre trânsito de bens, serviços e finanças levam, inexoravelmente, à eficiência e à competitividade, pilares do que se convencionou chamar de economias modernas. O principal exemplo seriam os Estados Unidos, onde a crença nessas regras se acentuou com o re-erguimento da economia norte-americana após a crise de 1929 (PAULANI, 2005).

a crise de 1929 foi a que mais gravemente traduziu as incoerências. Coube a J.M. Keynes redefinir os pressupostos da economia clássica, atribuindo ao Estado um papel natural dentro da evolução racional do capitalismo.

Com Keynes, mais precisamente com a publicação de Teoria Geral do Emprego, do Juro e da Moeda (1936), criou-se uma espécie de consenso sobre a necessidade de haver participação do Estado na economia.

O sucesso teórico dos princípios keynesianos foi acompanhado por uma reação também teórica e política contra o Estado intervencionista, logo após o término da Segunda Guerra. Essa reação, que adaptava os princípios do liberalismo ao capitalismo moderno, ganhou força e se espalhou com o nome de neoliberalismo (POLANYI, 1980).

${ }^{17}$ Enquanto os Estados Unidos se reerguiam da crise de 1929, coube a Friederich August Von Hayek papel de destaque no esforço de adaptar a teoria liberal às condições do capitalismo de meados do século XX. Ele procurou reduzir a tradição iniciada por Adam Smith de justificar o mercado como organização que maximiza o bem-estar coletivo. Para Hayek, o mercado deveria dominar tudo e o Estado deveria ficar reduzido ao papel de preservar as instituições que permitam o funcionamento adequado do mercado (POLANYI, 1980). Seu Caminho da Servidão, de 1947 tornou-se uma espécie de bíblia da nova doutrina, e o economista austríaco, naturalizado britânico, tornou-se o centro de um grupo de pensadores afinados com essas ideias, como Milton Friedman, Karl Popper, Lionel Robbins e Ludwig Von Mises. Hayek ganhou o Nobel de Economia de 1974 juntamente com Gunnar Myrdal. 
Influenciado pelo sucesso norte-americano e pela necessidade de reduzir os riscos às empresas capitalistas, que na época precisavam conquistar mercados externos para se expandir além das fronteiras de seus países, o ensino da economia nas escolas superiores, dominado por um discurso militante, se espalhou também pela Europa. Surgiram a literatura econômica e o jornalismo econômico, este último com a característica marcante de ser feito por militantes da modernização e corresponder a uma visão de mundo dos poderes econômicos privados (LEBARON, 2000:170).

Mas, em termos práticos, o neoliberalismo só começaria a se consolidar como ideologia a partir da séria crise enfrentada pelo capitalismo no fim dos anos 1960, quando os preços do petróleo e dos insumos básicos levando a um processo de recessão aberta e inflação em meados dos anos 1970. Nesse período, o mundo já se encontrava num sistema monetário puramente fiduciário, provocado pelo fim do sistema de Bretton Woods ${ }^{18}$. Não havia lastro ouro para o dólar e outras moedas fortes. O fim do sistema seria fundamental para a implantação do neoliberalismo, pois provocou uma onda geral a favor da desregulamentação dos mercados, sobretudo o financeiro.

Os anos 1978-80 foram um "turning-point" na história econômica mundial. Foi nesse período que neoliberalismo se consolidou como ideologia dominante, adotado como

\footnotetext{
${ }^{18} \mathrm{O}$ sistema de Bretton Woods foi definido pelas Conferências de Bretton Woods (Estados Unidos) de julho de 1944, que estabeleceram, entre outras coisas, a obrigação de cada país adotar uma política monetária que mantivesse a taxa de câmbio de suas moedas dentro de um determinado valor indexado ao dólar, cujo valor estaria ligado ao ouro numa base fixa. Em 1971, diante de pressões crescentes na demanda global por ouro, Richard Nixon, então presidente dos Estados Unidos, suspendeu unilateralmente o sistema de Bretton Woods, cancelando a conversibilidade direta do dólar em ouro (SOLOMON, 1976).
} 
solução para a crise inflacionária que assolava os países centrais. O marco político da prática neoliberal foi o período Thatcher, na Grã-Bretanha, acompanhado pelo governo Ronald Reagan, nos Estados Unidos. Mas antes, coube ao Chile, sob a ditadura Augusto Pinochet, ser o primeiro laboratório de práticas neoliberais em um pequeno país, que depois seria copiado por Thatcher.

Pinochet tomou o poder em 11 de setembro de 1973 contra o governo democraticamente eleito de Salvador Allende. O golpe foi promovido pelas elites empresariais do país, que se sentiram ameaçadas pela política socialista de Allende e teve apoio das grandes corporações dos Estados Unidos, da CIA (o serviço secreto norte-americano) e do então secretário de Estado Henry Kissinger (HARVEY, 2007:8). O governo Pinochet reprimiu todos os movimentos e organizações políticas de esquerda e desmontou todas as formas de organizações populares. A questão que se impunha à ditadura era como reviver uma economia estagnada. Um grupo de economistas ligados às teorias neoliberais de Milton Friedman, professor da Universidade de Chicago (EUA), foi chamado para reconstruir a economia chilena. O governo dos Estados Unidos financiava bolsas para economistas chilenos na Universidade de Chicago desde os anos 1950, como parte de um programa da Guerra Fria para conter tendências esquerdistas na América Latina. Nos anos 1970, o setor empresarial chileno se aproximou desses economistas, financiando o trabalho deles em instituições de pesquisas. Ficaram conhecidos como "Chicago Boys". Pinochet os trouxe para o governo com a missão primeira de conseguir empréstimos junto ao Fundo Monetário Internacional (FMI), o que exigia a reestruturação da economia chilena de acordo com os princípios neoliberais do Fundo. Os “Chicago boys”, segundo Harvey (2007)

a) Privatizaram ativos públicos; 
b) Abriram a exploração de recursos naturais (pesca, madeira) para o setor privado, muitas vezes ignorando os direitos e os protestos das populações indígenas;

c) Privatizaram o sistema de Previdência Social;

d) Facilitaram a entrada de investimento estrangeiro;

e) Abriram as fronteiras comerciais;

f) Priorizaram o crescimento por meio de exportações, substituindo o modelo anterior de substituição de importações;

g) Garantiram o direito de empresas estrangeiras no país repatriarem lucros ${ }^{19}$.

O único setor mantido sob a guarda do Estado foi o de cobre, ainda hoje a principal receita de exportação do Chile e vital para os cofres públicos (HARVEY, 2007:9).

O que se passou no Chile serviu de base para a virada neoliberal de Thatcher e Reagan. Margareth Thatcher, do partido conservador, foi eleita primeira-ministra britânica em maio de 1979, com um mandato voltado para reformar a economia, colocando fim à estagnação econômica com inflação que havia marcado a economia britânica em anos anteriores.

\footnotetext{
${ }^{19} \mathrm{~A}$ imediata retomada da economia chilena em termos de taxas de crescimento, acumulação de capital e altas taxas de retorno para o investimento estrangeiro durou pouco, até a crise da dívida da América Latina de 1982 (HARVEY, 2007:9). Até mesmo o tão elogiado modelo de Previdência Social adotado pelo Chile neoliberal tem se provado excludente, ineficiente e está em processo de mudança.
} 
Fortemente influenciada pelo pensamento do neoliberal "Institute of Economic Affairs" e com amplo apoio da mídia na formação da opinião pública, suas diretrizes foram provocar uma revolução nas políticas fiscal e social que haviam se consolidado na Grã-Bretanha após 1945, no governo trabalhista. Isso significou desmantelar o poder dos sindicatos, que passaram a ser fortemente criticados pela imprensa, acabar com os compromissos do Estado de bem-estar social, reduzir impostos, privatizar empresas e encorajar iniciativas empresariais, além de criar um clima de negócios favorável para induzir a entrada de capitais estrangeiros (Ibid., p. 59). Thatcher colocou nas mãos de capitais privados todo o imenso aparato estatal inglês (siderurgia, petróleo, telefonia, água, estaleiros, energia, gás, carvão, leite, seguro saúde, parte da alta tecnologia, aviação, construção aeronáutica, satélites, ferrovias, aeroportos). A "dama de ferro" foi inclusive contra a elite aristocrática que dominava o Reino Unido e se colocou ao lado dos novos capitalistas britânicos, os "nouveau riches", como Richard Branson, Lord Hanson e George Soros. O thatcherismo apresentou-se ao mundo como uma vitrine de resultados positivos de um programa neoliberal executado com determinação por uma liderança carismática.

Em 1980, Ronald Reagan foi eleito presidente dos Estados Unidos e também se empenhou em acabar com a força dos trabalhadores e em reduzir a legislação sobre a indústria, a agricultura e a atividade extrativa. Mas Reagan foi, principalmente, o grande arauto da liberalização do sistema financeiro dos Estados Unidos. Seu empenho em desregulamentar os mercados financeiros atravessou as fronteiras do país, espalhando pelo mundo o processo que ficou conhecido como globalização econômica, que é a prevalência dos princípios neoliberais-financeiros sobre outras vertentes econômicas. 
Já no período Reagan, um foco da exportação norte-americana era o vasto setor de serviços financeiros. Para que a expansão ocorresse, foi essencial a adesão do maior número possível de países ao sistema integrado de mercados financeiros comandados a partir de Nova York. Não bastava a integração tecnológica. Era fundamental que houvesse um compartilhamento do sistema de ideias. Para as economias periféricas, papel fundamental para a difusão do ideário neoliberal tiveram o Fundo Monetário Internacional (FMI) e o Banco Mundial (BIRD), instituições criadas no pós-Guerra e que mais tarde ditariam a conduta econômica que os países endividados internacionalmente deveria adotar. Esses organismos buscavam preservar a estabilidade monetária em termos planetários, assegurando um ambiente propício aos investimentos do mercado financeiro e garantindo o pagamento de juros e dividendos a detentores de papeis de dívidas públicas.

Exceto pelo caso chileno, a virada neoliberal mostrou mais claramente sua face na América Latina no final de 1989, quando veio público o resultado de uma reunião entre funcionários do governo norte-americano, do Banco Mundial, do FMI e do Banco Interamericano de Desenvolvimento (BID), convocada pelo IIE ("Institute for International Economics") e denominada "Latin American Adjustment: How much has happened?". Depois de ouvir os relatos de economistas latino-americanos sobre a experiência de seus países, muitos dos quais sob moratória, os representantes dos Estados Unidos e dos organismos multilaterais compilaram um série de princípios de inspiração neoliberal, amplamente divulgados, que veio a se chamar "Consenso de Washington", um receituário de abertura econômica à concorrência externa privada e de diminuição do tamanho do Estado que ratificou o 
neoliberalismo na região e que até hoje é considerado por seus críticos como o grande demônio da América Latina (BATISTA, 1994) ${ }^{20}$.

O "Consenso de Washington" preconizava o que já havia sido colocado em prática antes no Chile pelos "Chicago boys":

a) A abertura econômica com o fim das barreiras protecionistas ao comércio de bens e serviços e ao fluxo de moeda entre os países;

b) A privatização de empresas;

c) O fim das regras que limitam o movimento de capitais internacionalmente e no interior de cada país;

d) A "flexibilização" das leis de trabalho, que na prática significa reduzir direitos sindicais, trabalhistas e previdenciários;

e) Cambio flutuante.

\footnotetext{
${ }^{20}$ Em abril de 2009, com o aprofundamento da crise nos mercados financeiros iniciada no setor de hipotecas nos Estados Unidos e sua a ameaça de contaminação da economia real por conta do enxugamento do crédito, do potencial desemprego e da redução do consumo mundial, o criador do termo "Consenso de Washington", o economista britânico John Williamson, descartou em entrevista a jornal brasileiro que a atual crise tenha desqualificado seu receituário de livre mercado, mas se arrependeu de não ter recomendado mais supervisão do sistema financeiro. Ele admitiu que houve falhas na regulamentação financeira dos Estados Unidos, que levaram a uma proliferação de instrumentos financeiros complexos e difíceis de avaliar, além de um excesso de endividamento, que podem ter sido grandes responsáveis pela crise de 2008/2009. (WILLIAMSON, J. Consenso atenuou crise no Brasil. [Depoimento a Patrícia Campos Mello]. O Estado de S.Paulo. São Paulo, 12 de abril de 2009. Caderno de Economia, página 7).
} 
Com tudo isso, o objetivo final era enxugar o tamanho do Estado, gerando superávits fiscais para pagamento dos juros e do serviço da dívida pública. Ao mesmo tempo, com o aumento da liquidez internacional, intensificaram-se as pressões externas para que os países desregulamentassem seus mercados de capitais, internacionalizassem a emissão de papeis públicos e securitizassem suas dívidas (LOUREIRO, 1997:105).

Nesse meio tempo, a expansão global do ensino de economia teve impacto no Brasil. Houve, em menor grau dentro do regime militar iniciado em 1964 e em maior escala imediatamente após o fim da ditadura nos anos 1980, uma internacionalização da profissão de economista, puxada pela a ampla distribuição de bolsas de estudos para economistas, promovida por fundações norte-americanas - a exemplo do ocorrera no Chile. Uma parte importante desses profissionais, ligados à academia, foi formada em programas de Doutorado no Exterior, sobretudo nos EUA (LOUREIRO,1997). Somado ao "Consenso de Washington", foi esse processo de internacionalização acadêmica que trouxe ao País a retórica da modernização do governo Collor e que acabou batendo na imprensa por meio do discurso oficial. Os que não se dispuseram a aderir à autodenominada "modernização pelo mercado" foram desqualificados como retrógrados e "dinossauros" (BATISTA, 1994:8).

O discurso de modernidade neoliberal foi cabalmente absorvido por substancial parcela das elites políticas, empresariais e intelectuais da América Latina. No Brasil, com $82 \%$ de seus professores formados nos Estados Unidos, foi a PUC-Rio (Pontifícia Universidade Católica do Rio de Janeiro) que se transformou em um dos centros intelectuais do neoliberalismo globalizado, dentro de um movimento preparatório para a inserção do País no "Consenso de Washington", efetivado com o Plano Real, de 1994 (LOUREIRO, 1997). 
Ao mergulhar em um modelo reconhecido mundialmente como sinônimo de sucesso, os economistas brasileiros se sofisticaram. O conhecimento matemático e estatístico adquirido no Exterior os tornou muito requisitados para ocupar cargos de frente em sucessivos governos, fazendo com que, nas palavras de Loureiro (1997), prevalecesse no País um autoritarismo tecnocrático, que impôs a superioridade da razão técnica sobre a política e justificou a atrofia do Executivo como condição de eficiência da ação estatal. O receituário de desregulamentação conquistou no Brasil até as elites industriais, sempre dependentes do Estado, onde buscavam isenções fiscais. Mostra disso é uma publicação, uma espécie de cartilha, divulgada em agosto de 1990 pela conservadora Federação das Indústrias do Estado de São Paulo (Fiesp), sob o título "Livre para Crescer - Proposta para um Brasil Moderno". O texto nada mais era do que a sugestão, dos empresários para o governo, de uma agenda de reformas idênticas às defendidas pelo "Consenso de Washington".

Inserir o Brasil no mundo globalizado era um projeto de Estado que o PSDB queria levar a diante nos anos 1990. Para que essa inserção pudesse acontecer, o Brasil teria de buscar um ambiente interno de estabilidade, sem inflação. A oscilação descontrolada de preços era um risco à elaboração dos cálculos de projeção que definem o movimento dos mercados de capitais. Sob a retórica da modernização, da eficiência e da formalização, a ideia de inserção internacional peessedebista seguiu de perto as prescrições do "Consenso de Washington”. O Plano Real de 1994 do ministro Fernando Henrique Cardoso finalmente 
conseguiu abrir as portas para o Brasil entrar no mundo globalizado, mediante as seguintes condições (SOUZA, 2007:222):

a) Securitização da dívida externa;

b) Criação da âncora monetária por meio da elevação das taxas de juros;

c) Criação da âncora fiscal, mediante a criação do Fundo Social de Emergência;

d) Transição para uma nova moeda, por meio da criação de uma unidade de conta, a Unidade Real de Valor (URV);

e) Criação da nova moeda, o Real;

f) Criação da âncora cambial, por meio da valorização da moeda e a aceleração da abertura econômica;

g) Implementação de um amplo programa de desestatização da economia;

h) Eleição de Fernando Henrique Cardoso, então ministro da Fazenda, à Presidência da República. 
A equipe que criou o Real, em sua maioria professores vindos da PUC-RJ, alegava que, misturando-se bem tudo aquilo, depois de certo tempo o País estaria preparado para pegar o “bonde da história" (PAULANI, 2008:40) ${ }^{21}$.

O conjunto de ideias que guiaram o Plano Real defendia que:

a) A abertura comercial promoveria um choque de concorrência para o sistema produtivo nacional, que passaria assim a desfrutar de um lugar no mundo globalizado, garantindo o crescimento sustentável. Quer dizer, os produtos brasileiros seriam obrigados a se modernizar (e ficar mais baratos) para enfrentar a competição externa;

b) O Estado mínimo e as políticas fiscais e monetárias sólidas com juros reais elevados, além de serem antídotos naturais contra a inflação, assegurariam a credibilidade dos investidores externos aumentariam a entrada de dinheiro e resolveriam os problemas do balanço de pagamentos;

c) A reestruturação produtiva faria elevar os salários, constituindo assim instrumento para a redução das desigualdades distributivas.

\footnotetext{
${ }^{21}$ No começo dos anos 1990, a renegociação da dívida externa, sua securitização, e a criação dos títulos da dívida brasileira cotados em mercados internacionais já haviam se encarregado em parte da tarefa. Ao mesmo tempo, o Banco Central se encarregava de desregulamentar o sistema financeiro, utilizando para isso o mecanismo das CC5, criado em 1962. São contas de não-residentes, cuja abrangência foi ampliada com o alargamento do já existente conceito de não-residentes para contas livres de instituições financeiras do Exterior não-autorizadas a operar no País. Além disso, as CC5 passaram a poder remeter livremente para o Exterior não apenas os saldos em moedas domésticas resultantes da conversão da moeda estrangeira com a qual os não-residentes tivessem entrado no País, mas todos e quaisquer saldos. Sem essas mudanças, por exemplo, os mais de US\$ 40 bilhões que saíram do País entre setembro de 1998 e janeiro de 1999, atemorizados com a iminente desvalorização do Real, não poderiam fazê-lo e teriam amargurado duras perdas (PAULANI, 2008:42).
} 
Foge ao escopo deste trabalho avaliar se o modelo adotado alcançou os objetivos retóricos de abrangência e inclusão social. Críticas e defesas a ele não faltam. Mas vale reproduzir o pensamento do ex-ministro do regime militar, ex-deputado federal, professor emérito da Universidade de São Paulo (USP) e consultor da Fiesp, Antônio Delfim Netto (Apresentação. In: PRADO, 2005:10), o venerado maestro do "milagre econômico" brasileiro dos anos 1970 (Capítulo 3). Segundo ele, o que se sabe em termos puramente macroeconômicos é que os brasileiros trocaram o grave problema da inflação por três problemas igualmente indesejáveis e que não precisariam necessariamente ter ocorrido em razão do programa de estabilização (o Plano Real): um enorme desemprego causado pelo baixo crescimento econômico durante oito anos seguidos, uma dívida de quase $2 / 3$ do PIB, que exigiu a elevação da carga tributária de $27 \%$ para $38 \%$ do PIB e uma delicada situação de constrangimento externo decorrente da acumulação de um déficit de US\$ 180 bilhões em conta corrente.

Os bilionários recursos das privatizações no setor de minério, siderúrgico, de energia e comunicações não tiveram como destino qualquer programa social. O dinheiro, segundo o próprio governo Fernando Henrique Cardoso, serviu para amortizar a dívida pública - o que só beneficiaria aos credores. O Brasil ainda continua refém do capital externo, mantém a desconfortável posição de exportador de commodities primárias e não consegue resolver seus problemas desigualdade social, miséria e violência. 


\subsection{A RACIONALIDADE TÉCNICA COMO ELEMENTO DE PERSUASÃo}

A economia é um campo novo de conhecimento, quando comparada à filosofia, à medicina, à astronomia e às artes da guerra, por exemplo. Sempre fora uma ciência muito mais social do que da natureza ou exata. A economia política, do século XVII, dedicava-se a estudar as relações de produção entre capitalistas, proletários e latifundiários. Tem lugar cativo entre as Humanas e somente se realiza como ciência se interagir com os conhecimentos que se interrogam a respeito do homem em sociedade. Pouco a pouco, porém, a partir do final do século XIX, a denominação economia política, muito ligada a pressupostos éticos, foi sendo substituída por economia, usada por aqueles que buscavam abandonar a visão de classes da sociedade. A economia, então, ganhou um enfoque mais matemático, axiomático e valorizador do cálculo, dentro da ideologia moderna de que aquilo que em virtude do cálculo é demonstrável, organizável e previsível não exige a caução de nenhuma autoridade para ser dado como verdadeiro e universalmente válido (LEBARON, 2000; GORZ, 1988). A economia deixou de ser dedutiva para se tornar prescritiva, e sua ligação com o cálculo e a estatística tem sustentado-a como uma ciência exata. A forma moderna de se pensar o mundo deu força às ferramentas da contabilidade, que contribuíram ao mesmo tempo para o desempenho dos agentes econômicos e para a formação de um discurso científico, desatrelando a economia de seu conteúdo social (POLANYI, 1980:26). A crise de 1929 alertara o mundo capitalista sobre a necessidade de se calcular e de se prever riscos à ordem natural dos mercados, que supostamente só poderiam ser controlados se todas as esferas da sociedade e a própria vida dos indivíduos fossem conduzidas de maneira racional, 
previsível e calculável. Assim, a matematização da atividade econômica se tornou uma necessidade intrínseca ao sistema econômico. Com o avanço da tecnologia no século XX, os instrumentos contábeis e estatísticos de projeção ficaram cada vez mais sofisticados. Foi assim, numa espécie de aliança com o avanço tecnológico, que o sistema matemático de estatísticas econômicas ganhou cada vez mais reconhecimento como instrumento para orientar os agentes no complexo e arriscado universo da atividade econômica (CALLON, 1998).

Ao mesmo tempo em que teve papel relevante na elaboração das estratégias das empresas, a prática de projeções futuras a partir de acontecimentos passados, a econometria ${ }^{22}$, acabou sendo incorporada também pelo Estado. $\mathrm{Na}$ atualidade, por exemplo, mede-se o desempenho de um país por meio da variação numérica de indicadores, como o Produto Interno Bruto (PIB), a balança comercial, a relação dívida/PIB, a formação bruta de capital fixo, a produção industrial ${ }^{23}$. Nas últimas décadas, projetar esses números ficou muito

\footnotetext{
${ }^{22}$ Econometria é o ramo da economia que cuida do estabelecimento de leis quantitativas para os fenômenos econômicos. Analisa os dados fornecidos pela estatística a partir da aplicação de métodos matemáticos. Exprime em linguagem matemática as leis econômicas (SANDRONI, 1985:126).

${ }^{23}$ Os modelos econométricos não consideram em suas projeções acontecimentos políticos, fenômenos naturais ou mesmo mudanças no comportamento do consumidor (o princípio que vale é o de que a economia é uma esfera autônoma da vida social). Qualificam-se como modelos neutros e, portanto, livres de influências políticas e desideologizados (PORTER, 1995; PAULANI, 2005; DUPAS, 2005; ORTIZ, 2006).

Há ainda a questão da essência manipulável dos números:

O economista Waldir Quadros, professor da Unicamp (Universidade Estadual de Campinas), no entanto, faz a seguinte ressalva: “A partir dos números é possível se construir qualquer cenário. Não há uma verdade única. Os números ganham interpretações diferentes nas mãos de economistas diferentes". A representação concebida pelo mercado financeiro por meio da matemática pode esconder interesses que nem sempre o jornalista é capaz de perceber (QUADROS, 2004).

Na mesma linha da essência manipulável dos números na construção da realidade econômica, o mexicano Guillermo Orozco (1996), especialista em Educação e Comunicação, dá um testemunho inspirador. Ele conta que, até 20 de dezembro de 1994, os mexicanos acreditavam estar a um passo do primeiro mundo. Era o que mostravam os números da atividade econômica divulgados pelo governo e pelos bancos de investimento na imprensa: a Bolsa de Valores e o Produto Interno Bruto (PIB) estavam em alta, a inflação, controlada abaixo dos dois dígitos e, pela primeira vez em 20 anos, o México registrava um superávit comercial com os Estados Unidos. Todos os indicadores levavam a pensar que estava-se passando pelo segundo milagre mexicano.
} 
menos complicado, já que existem ferramentas de cálculo e planilhas disponíveis em programas de computador, às quais acrescentam-se variáveis numéricas passadas para se revelar o futuro. Tais planilhas parecem hoje ser o mais importante instrumento de trabalho dos economistas do mercado financeiro. Parece fato que as projeções são essenciais para se criar expectativas, positivas ou negativas, que permitam o planejamento em quaisquer tipos de atividades. O problema é que a visão puramente racional/matemática da economia exclui as dinâmicas políticas como determinantes dos processos econômicos. Os economistas não previram, por exemplo, as crises monetárias dos anos 1990 no México, na Ásia e Argentina (FURTADO, 2000:14), tampouco a crise global iniciada em 2008 nos Estados Unidos.

O fato é que o apego exclusivo aos fundamentos matemáticos, desprezando as reflexões da economia política, fez com que, na atualidade, a corporação dos economistas se sentisse convicta de que é portadora de uma ciência capaz de ensinar a governos, empresários e trabalhadores como devem se comportar para obter, respectivamente, a boa governança estatal, empresarial e o máximo bem-estar da sociedade (NETTO, 2008). Quando se procura questionar essa crença, percebe-se que a ortodoxia econômica atual é provavelmente um dos discursos mais potentes a respeito do mundo social, "pelo fato, notadamente, de que a formalização matemática lhe confere as aparências ostentatórias do rigor e da neutralidade" (BOURDIEU, 2005:54). Os financistas se apresentam à sociedade

Só que esses dados, escolhidos a dedo para vir a público, segundo ele, deixavam de lado outros indicadores: enquanto os analistas olhavam o crescimento do PIB, deixavam de lado quais eram as fontes desse PIB: o número total crescia, mas não mostrava que o incremento se dava às custas de uma crescente monopolização das grandes indústrias, do desaparecimento da pequena e média empresa e de um desemprego que crescia aos poucos. E havia aumento da pobreza: em uma população de 80 milhões, $30 \%$ estavam em estado de pobreza absoluta. Ao contrário do que mostravam os números na mídia, o México não estava a um passo do primeiro mundo, mas da primeira crise causada entre os países periféricos que adotaram o modelo neoliberal. 
com o discurso da modernidade racional, que defende a liberdade de escolhas individuais, a justiça e a dignidade humana só obtidas pelas leis racionais do livre mercado. Constroem consensos em torno de suas ideias, formando uma espécie de barreira ideológica, porque quando há consenso, a sociedade passa a ser guiada por um pensamento incontestável e não dá espaço para alternativas (GOMES, 2003; GRUN, 2005; ORTIZ, 2006; MAGALHÃES, 2007). Quem ousa criticar o modelo econômico predominante é estigmatizados como retrógrado e obsoleto ${ }^{24}$.

\footnotetext{
${ }^{24}$ Há toda uma linha de reflexão crítica ao pensamento único e à racionalidade técnica da economia que os relaciona muito mais a aspectos de dominação do que à defesa de valores ligados à liberdade. Lebaron (2000) e Gorz (2003) afirmam que a economia, como ciência, guarda estreita ligação com o cálculo. Mas, por ser protagonizada pelo homem, a economia é, na verdade, muito mais uma ciência social do que exata. E a sua estreita ligação com o social tira dela a suposta objetividade que a racionalidade científica dos economistas quer lhe atribuir, deixando-a susceptível à condições sociais de sua aplicação. Bourdieu (2005), por exemplo, sustenta que o pensamento único é menos ocupado em observar a realidade do que em construir um ambiente sem riscos para o andamento dos negócios. Para ele, nunca existiu o homo oeconomicus, aquele ser humano que faz apenas escolhas racionais baseado em leis de demanda e oferta de mercado. O homem, continua ele, é mais complexo do que qualquer número poderia mostrar, pois pertence a uma época, a um país, a uma família, tem crença e ideias políticas. Gorz (2003:46), na mesma linha, sustenta que o homo oeconomicus "não passa de um monstro antropológico, uma falácia escolástica, criado para que se pudessem aplicar as teorias."

Diante das catástrofes das bombas atômicas jogadas em Hiroshima e Nagasaki em 1945 e dos experimentos com seres humanos dos nazistas, possíveis por conta do avanço das condições técnicas e científicas, Adorno e Horkheimer apontaram em 1947 a racionalidade técnica como a racionalidade da dominação. Para eles, a razão é mais totalitária do que qualquer sistema. (MATTELART; MATTELART, 2004:78). Marcuse disse que a racionalidade técnica e a razão instrumental reduziram o discurso e o pensamento a uma dimensão única, anulando o espaço do pensamento crítico e tornando a razão instrumental ditatorial e totalitária. Marcuse, Adorno e Horkheimer compartilharam da visão de que todo o potencial emancipatório pregado pela ciência estaria voltado para a reprodução do sistema de dominação e sujeição. A razão, defenderam eles, comporta-se em relação às coisas como um ditador em relação aos homens. Na mesma linha, Habermas classifica a técnica e a ciência como ideologia. Os problemas políticos são reduzidos a seu aspecto técnico, derivado de uma administração racional (MATTELART, 2004).

A racionalização da sociedade constrói a ideologia de mito e aplica todos os poderes técnicos da racionalização a serviço desse mito. Assim, a visão de um só aspecto das coisas (rendimento, eficácia), a explicação em função de um fator único (o econômico ou o político), a crença que os males da humanidade são devidos a uma só causa e a um só tipo de agente, constituem outras tantas formas de racionalização (MORIN, 1982:205). A razão do século XVIII aparece não só como força de emancipação Ocidental, mas também como princípio, justificando a subjugação operada por uma economia, uma sociedade, uma civilização sobre outras (Ibid., p. 210).
} 


\section{CAPÍTULO 2}

\section{REFERENCIAL TEÓRICO - 2}

\section{JORNALISMO E GRUPOS DE INTERESSE}

O jornalista tem o poder do reconhecimento da notícia e de projetá-la para além de sua própria circunscrição, bem como legitimar perante a sociedade as pessoas que dão entrevistas sobre determinado assunto. E por ter o monopólio de saber o que é notícia, ele é disputado por partidos, governos, sindicatos, indústrias, movimentos sociais, organizações e outras instâncias da sociedade civil (ALDÉ; XAVIER; CHAGAS, 2005) que buscam espaço para se manifestar e legitimar. Estar no noticiário não é um processo que se pode chamar de natural, mas um caminho estrategicamente construído. É a profissionalização da relação como os jornalistas que garante espaço aos diversos agentes e, nesses termos, podese dizer que o acesso ao campo jornalístico é uma conquista (ALDÉ, 2004).

O desafio da imprensa, que tem padrões éticos e democráticos, é construção de uma sociedade saudável e plural, que só se consegue com equilíbrio de interesses (HA-JOON, 2009). Na prática, porém, o noticiário brasileiro promoveu a difusão sistemática de fatos e temas econômicos pelas vozes de economistas do mercado, banqueiros, consultores, ex- 
ministros e ex-diretores do Banco Central, todos porta-vozes das altas finanças (ARAÚJO, 1998:X), revelando um modelo acrítico e não-plural de se fazer jornalismo ${ }^{25}$.

Economistas abastecem diariamente os jornalistas com estudos de cunho técnico, cheios de números, gráficos e projeções, sempre seguidos de comentários e interpretações. Esses estudos quase que diariamente dão ideias para matérias. Daí a proliferação e a valorização pela imprensa de temas "mágicos" entoados diariamente: déficit fiscal, superávit primário, valor de mercado, risco-país, ações, colocação de títulos, leilões de dólares, produção industrial, indicadores antecedentes, curva de juros, rentabilidade, mercado e mais uma infinidade de termos que compõem o "economês", uma língua compreendida apenas por “iniciados”. É com esse discurso científico que os financistas constroem sua credibilidade junto à imprensa, tornam-se fontes e se legitimam perante a sociedade como detentores do único conhecimento correto. Quem é cientificamente reconhecido aparece como importante para os outros (DUPAS, 2005; PAULANI, 2005; ORTIZ, 2006).

Por trás da intenção de se legitimar perante à sociedade há todo um objetivo final de influenciar as esferas mais altas do poder. As ideias defendidas pela classe econômica dominante precisam influenciar os políticos e os diversos níveis do governo, do Executivo aos cargos mais técnicos, porque o governo e seus técnicos são responsáveis por guardar as reservas do País, emitir moeda, vender ativos, definir taxas de juros e mecanismo de

\footnotetext{
${ }^{25}$ O professor André Araújo (1998) realizou uma pesquisa sobre o amplo apoio dos meios de comunicação ao plano de estabilização econômica de 1994. Ele analisou O Estado de S.Paulo, O Globo, Jornal do Brasil, Folha de S.Paulo, Gazeta Mercantil, Veja, Isto É, Carta Capital, Exame e Isto É Dinheiro, na mídia impressa, e concluiu que esses veículos foram, de forma geral, coniventes com o modelo econômico e omissos na crítica à política econômica. Araújo afirmou ainda que um dos grandes capitais políticos do PSDB, que o distingue de partidos aliados, é o íntimo e profundo relacionamento com a imprensa, por meio de afinidades sociais e intelectuais do PSDB de Fernando Henrique Cardoso com as redações.
} 
comércio exterior, sancionar a legislação e determinar todas as outras linhas das políticas fiscal, monetária e de utilidade pública.

Para influenciar a contento os políticos, o governo e a sociedade, a classe econômica dominante precisa construir, primeiramente, uma rede de apoio além dela própria que lhe dê credibilidade. Essa rede é formada basicamente pela academia e pela imprensa. A imprensa é peça-chave na construção de consensos, porque define e mostra à sociedade o que deve fazer parte da agenda de interesses nacionais. Os grupos de interesse querem a cooperação dos jornalistas para aparecer, e os jornalistas querem a cooperação dos grupos para ter notícias. É a cooperação que vai responder, em grande medida, à escolha de determinado tema e enfoque no noticiário em detrimento de outros assuntos e agentes (STEINER, 2006).

\subsection{A CONSTRUÇÃO DA NOTÍCIA E A DEFINIÇÃO DA}

\section{AGENDA (“AGENDA-SETTING”)}

O jornalismo é um campo legitimado pela ideia de que a democracia é um regime político superior. Dentro dessa ideologia, caberia à imprensa:

a) Vigiar o poder político e proteger os cidadãos dos eventuais abusos dos governantes; 
b) Fornecer aos cidadãos informações necessárias para o desempenho de suas responsabilidades cívicas (TRAQUINA, 2004).

O ethos contemporâneo da profissão, que se formou a partir das estreitas ligações do jornalismo com os ambientes democráticos, é o de trabalhar com a verdade, de forma neutra, imparcial, objetiva. É o que garante à imprensa credibilidade perante a sociedade. “Os jornalistas são vistos como os responsáveis pela transparência da administração pública, e pela denúncia e vigilância do poder político, através da incumbência, que lhe atribuem os espectadores, de fornecer-lhes a essência dos fatos políticos" (ALDÉ, 2004). Nas sociedades de massa, os jornalistas têm ainda o papel de organizar as informações a apresentá-las à sociedade. Isso reflete códigos de ética aplicada que, embora variem de sociedade para sociedade, enfatizam a busca da verdade e do interesse público.

Mas a imprensa, ao destacar um assunto em detrimento de outro, agenda a opinião pública. Os profissionais da notícia funcionariam como "gatekeepers" (porteiros) das informações, deixando passar algumas e barrando outras. O que o público sabe e com o que se importa em dado momento é, em grande parte, um produto do "gatekeeping" midiático, segundo a teoria de "agenda-setting" (KOVACK; ROSENSTIEL, 2004). Na prática, os jornalistas definem o que vai virar notícia diante de critérios de noticiabilidade ${ }^{26}$ e de interações entre

\footnotetext{
${ }^{26}$ A noticiabilidade, segundo Wolf (2001), é a aptidão de um fato para tornar-se notícia. Podem-se destacar entre esses critérios (ou valores-notícia):

Momento do acontecimento: quanto mais as características temporais servirem às necessidades do meio, mais facilmente um fato vira notícia;

Intensidade: quanto maior a magnitude de um acontecimento, maior a probabilidade de ser noticiado; Clareza: a inexistência de dúvidas é diretamente proporcional à hipótese de um evento se tornar notícia;

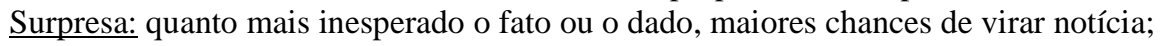
Continuidade: a noticiabilidade de um acontecimento aumenta as chances de haver repercussões a partir dele, gerando mais notícias para os dias seguintes;
} 
os próprios jornalistas, que reivindicam o monopólio de saber o que é notícia, reconhecê-la, coletá-la, torná-la importante, destacá-la e de dominar a linguagem jornalística, e os diversos agentes sociais, que pretendem mobilizar as notícias como um recurso social em prol das suas estratégias comunicacionais com a sociedade.

Enquanto os jornalistas precisam ter diariamente ideias que gerem matérias e fontes (pessoas a entrevistar) disponíveis, as fontes precisam dos meios para se comunicar com os ambientes externos. Trata-se de uma relação de recíproca conveniência (CHAPARRO, 1994:73). Atualmente, redações enxutas e relógios correndo cada vez mais rapidamente contra o fechamento dos jornais acabaram levando os jornalistas a depender de um número pequeno de fontes regulares, que acabam por dominar a relação porque estão sempre disponíveis e, ao mesmo tempo, aptas a oferecer assuntos que podem virar matérias e explicar as peculiaridades da macroeconomia contidas nas pautas (sugestões de reportagens ou entrevistas) mais complicadas, que envolvem engrenagens de política econômica ${ }^{27}$.

Fontes disponíveis e de credibilidade podem ser chamadas de definidores primários "primary definers" (HALL, 1973 apud TRAQUINA, 2004:177/178). Eles geram os dados e os fatos que irão suprir as necessidades dos jornalistas. Os "primary definers" sabem oferecer material para notícias de acordo com o perfil de cada veículo de comunicação.

Valores socioculturais: o valor-notícia varia de acordo com padrões culturais vigentes.

${ }^{27}$ Um exemplo é o economista Sergio Vale, da consultoria MB Associados, que pertence ao ex-ministro José Roberto Mendonça de Barros (governo FHC). Antes da consultoria, Vale trabalhou no jornal O Estado de S.Paulo, como uma espécie de consultor para o noticiário econômico. Além de fazer amizade com alguns jornalistas, o economista passou a dominar a linguagem jornalística. Agora, na MB, Vale é um dos economistas que mais aparecem no noticiário de todos os jornais. Oferece inúmeros trabalhos estatísticos que servem como pautas, é muito acessível e simpático. 
Assessorados por profissionais, sabem inclusive que a rotina jornalística, sistematicamente pressionada pelo relógio, exige fatos novos todos os dias.

Analisando a relação entre mercado financeiro e jornalismo, Grun (2005) afirmou que os economistas sabem muito bem o grau de impacto que as notícias têm sobre o próprio mercado e a agenda nacional. Por isso, têm como hábito cortejar os jornalistas. Para Hall, há uma posição de subordinação dos jornalistas em relação aos "primary definers" (que também inclui o governo), porque os jornalistas aceitam a definição do noticiário por parte dessa elite. Quando o jornalista conversa com um economista de mercado, ele se depara com um tom sacerdotal, que pode fazê-lo sentir-se intimidado em pedir explicações mais aprofundadas sobre o que o entrevistado está falando. Para fazer parte desse mundo especializado, ele vai buscar no próprio mercado financeiro a compreensão dessa linguagem. Ou pela criação de laços com economistas que se mostram sempre disponíveis ou por meio dos inúmeros cursos de economia oferecidos gratuitamente a jornalistas por associações do próprio mercado financeiro, questões que serão abordadas mais abaixo.

\subsubsection{A HIERARQUIA DA CREDIBILIDADE}

Dentro do código deontológico que rege a profissão, uma fonte só deve ser reconhecida como tal se desfrutar de credibilidade - algo que inclusive ajuda na produção jornalística na medida em que reduz a necessidade de checagem da informação. Segundo Traquina (2004:190), autoridade e produtividade são os fatores que mais conferem credibilidade a uma fonte: 
a) Autoridade: fontes oficiais ou que ocupam posições institucionais de autoridade e acadêmicos. É possível que o jornalista use a fonte mais pelo que é do que pelo que sabe, pois a maioria das pessoas acredita na autoridade da posição. Fontes que ocupam uma posição de autoridade formal são consideradas mais credíveis do que outras;

b) Produtividade: quantidade e qualidade de material que a fonte fornece, diretamente ligada à necessidade que o jornalista tem de limitar o número de fontes a consultar por conta de custos e prazos limitados. As fontes produtivas fornecem os materiais suficientes para fazer a notícia;

No que se refere à autoridade, uma fonte cresce ainda mais em credibilidade se for, membro ou ex-membro do governo, empresário de sucesso ou economista de banco renomado, ou ainda pesquisador de alguma instituição importante. Os repórteres buscam valorizar suas matérias entrevistando ex-ministros da Fazenda e ou ex-presidentes e exdiretores do Banco Central. Mas, creditá-los como ex-autoridades na maioria das vezes ofusca o fato de que a fonte pode ser, na verdade, dirigente de uma instituição financeira privada, portanto parte interessada no andamento da política econômica e das normas que refém o mercado financeiro.

O ex-ministro da Fazenda Mailson da Nóbrega, sócio-fundador da Tendências Consultoria Integrada, e o ex-diretor do Banco Central Alexandre Schwarstman, economista-chefe de 
América Latina para o Santander, por exemplo, estão entre as fontes mais acessíveis e de alta credibilidade por conta dos cargos altos que ocuparam. Entre as consultorias, a MB Associados, do ex-secretário de Política Econômica José Roberto Mendonça de Barros, é provavelmente a que mais estudos oferece à imprensa e também desfruta de muita credibilidade.

De forma geral, essas fontes são profissionais dotados de altos conhecimentos técnicos, com habilidades discursivas. Muitas saíram da área acadêmica ou mesmo de bancos e foram para o governo, tendo o serviço público não necessariamente como um fim, mas mais provavelmente como um meio para chegar ao (ou se consolidar no) setor privado, como renomados consultores ou diretores de instituições (LOUREIRO, 1997) ${ }^{28}$. A consultoria de monitoramento de conjuntura econômica, por exemplo, cresceu enormemente no Brasil nas duas últimas décadas nas áreas de administração do caixa e projeções de cenários macroeconômicos. O prestígio dos consultores e o nível de sua remuneração estão diretamente relacionados aos postos que ocuparam no governo e à visibilidade que têm na imprensa. Muitos escrevem regularmente nos principais jornais de São Paulo e do Rio de Janeiro.

Um levantamento ${ }^{29}$ mostra a considerável gama de ex-ministros e ex-autoridades do Banco Central que, após deixar o governo, foi dirigir bancos/consultorias ou retomar antigos postos com remuneração muito superior:

\footnotetext{
${ }^{28}$ Há também os que saem do setor privado e vão para o governo seguir carreira política.

${ }^{29}$ A partir da agenda da autora do trabalho, em 2008.
} 
Pedro Malan, ex-ministro da Fazenda: Unibanco;

Mailson da Nóbrega, ex-ministro da Fazenda: sócio-fundador da Tendências Consultoria Integrada;

Gustavo Loyola, ex-presidente do BC: sócio-fundador da Tendências Consultoria Integrada;

Marcos Lisboa, ex-secretário de Política Econômica do Ministério da Fazenda: Unibanco; Armínio Fraga, ex-presidente do BC, era do mercado financeiro antes de assumir o cargo e quando saiu foi dirigir a Gávea Investimento;

Gustavo Franco, ex-presidente do BC: sócio-fundador da Rio Bravo;

Carlos Kawall, ex-diretor do BC: também era do mercado financeiro e tornou-se sócio de Franco na Rio Bravo;

Luiz Fernando Figueiredo, ex-diretor do BC: Mauá Investimentos;

Ilan Goldfajn, ex-diretor do BC: Ciano Investimentos;

Sérgio Werlang, ex-diretor do BC: Itaú;

Alexandre Schwartsman, ex-diretor do BC, era do mercado, foi para o BC e atualmente é analista-chefe do ABN Amro/Santander;

Eduardo Loyo, ex-diretor do BC: UBS/Pacutal;

Joel Bogdanski, ex-BC: Itaú;

Marcelo Kfouri, ex-BC: Citibank;

Carlos Geraldo Langoni, ex-presidente do BC: Projeta Consultoria;

Affonso Celso Pastore, ex-BC: consultoria A. C. Pastore;

Luiz Carlos Mendonça de Barros, ex-ministro das Comunicações: dono da empresa de investimentos Quest; 
José Roberto Mendonça de Barros, ex-secretário de Política Econômica: dono da consultoria MB Associados;

Sérgio Goldenstein, ex-BC: ARX Capital Management;

Beny Parnes, ex-BC: BBDM

Henrique Meirelles, presidente do Banco Central desde 2003, foi presidente do BankBoston;

Um caso fora do âmbito BC-Ministério da Fazenda, mas igualmente revelador é o do exSecretário de Direito Econômico (SDE) do Ministério da Justiça, Daniel Goldberg. A SDE tem entre suas atribuições lidar com questões legais de fusões e aquisições de empresas. Goldberg saiu do governo e passou a ocupar, pouco tempo depois, a o cargo de diretor do Departamento de Fusões e Aquisições do banco de investimentos Morgan Stanley.

\subsubsection{O PAPEL DAS ASSESSORIAS DE IMPRENSA}

Excluindo-se o caso de ex-autoridades, que praticamente têm espaço garantido na imprensa, cada vez mais o conhecimento técnico de como ocupar espaço no noticiário torna-se um capital político e disputado. Para os que têm recursos para contratá-las, as assessorias de imprensa trabalham cuidadosamente a inserção de fontes no noticiário, considerando que seu trabalho básico é o de legitimar seus clientes junto à imprensa. As assessorias são empresas de comunicação, com equipes formadas por jornalistas, relações públicas e profissionais de marketing. Também são as maiores contratantes de jornalistas no Brasil, e a grande maioria dos donos dessas empresas veio de redações ou de assessorias institucionais. Desde que as assessorias de imprensa passaram a apresentar um promissor 
mercado de trabalho para os jornalistas no início dos anos 1980, a área não parou de crescer. Uma estimativa feita a partir do Guia Brasileiro de Comunicação Empresarial e Assessorias de Imprensa (2001) revela que no ano 2000 eram mais de mil assessorias em todo o Brasil, número que poderia ser multiplicado por quatro quando consideradas as assessorias corporativas, aquelas das próprias empresas, não-tercerizadas. No fim de 2006, segundo dados do Sindicato dos Jornalistas do Estado de São Paulo, eram mil e cem (1.100) assessorias apenas no Estado de São Paulo.

Em termos práticos, a relação que se estabelece com os jornalistas obedece a rotinas de trabalho que incluem comunicados, conferências de imprensa, almoços e até a concessão de informações exclusivas. O papel mais simples das assessorias de imprensa é divulgar o material das instituições e organizar entrevistas. O mais sofisticado é o treinamento das fontes para conceder entrevistas e se portar frente aos repórteres, o chamado "media training" (Anexo D) ${ }^{30}$. As empresas de maior porte têm suas próprias assessorias, chamadas corporativas, como é o caso da Embraer, no setor industrial, e do Bradesco e Unibanco, na área financeira. Algumas empresas têm os dois tipos de assessoria, a interna e a externa, embora atualmente seja cada vez mais comum entidades do setor privado terceirizarem $\operatorname{assessorias}^{31}$.

\footnotetext{
${ }^{30} \mathrm{O}$ crescimento das assessorias aconteceu em parte porque o espaço publicitário na mídia ficou cada vez mais caro. Em vez de anunciar, a empresa contrata uma assessoria, cujo papel é colocar o nome da empresa em evidência, mas não por meio da propaganda, e sim pela criação de um fato noticioso cujo personagem principal é a empresa (QUINTÃO, 1987).

${ }^{31}$ As assessorias de imprensa têm também outro papel, que é o de aprovar o contato entre um jornalista e uma fonte. Grandes empresários, banqueiros ou acadêmicos muito conhecidos, por exemplo, só falam com um ou outro jornalista e de um ou outro jornal. Como têm espaços garantidos na mídia por conta de sua hierarquia e credibilidade, falam quando querem e só com quem querem.
} 
O papel das assessorias é fundamental no processo de apresentar e legitimar fontes. Sempre buscando cooperar com os jornalistas a favor de seus clientes. O controle que as fontes querem exercer sobre o noticiário pressupõe, também, sua submissão aos constrangimentos da produção jornalística, basicamente a pressão por encontrar notícias, os prazos de fechamento e o perfil editorial do veículo (MORETZSOHN, 2002:69). Em uma entrevista, a fonte preparada fornece elementos úteis, como dados estatísticos, fotografias, dossiês e dados biográficos, sempre facilitando o trabalho do jornalista.

As assessorias devem também criar agendas noticiosas para que seus clientes tenham o que falar, mas sempre tendo em mente que a decisão de definir a matéria é domínio do jornalista. $\mathrm{O}$ assessor de imprensa tem a vantagem de dominar o processo jornalístico, de forma a gerar fatos/dados de seus clientes com forte potencial de virar notícia. O email é hoje o contato primeiro entre as assessorias e os jornalistas (Anexo C). Mas distribuir sugestões de matérias por correio eletrônico não garante conquista. Os jornalistas de veículos impressos precisam de material diferenciado, exclusivo e de boa qualidade. Então, os assessores de imprensa procuram estabelecer um relacionamento mais pessoal com os repórteres de suas áreas de interesse: telefonam com frequência, chamam para coletivas e para encontros exclusivos com as fontes.

\subsubsection{1 "MEDIA TRAINING"}

O objetivo do treinamento de mídia ("media training”) é treinar executivos para o contato com a imprensa, orientá-los nas diversas situações de entrevistas e familiarizá-los com o 
mundo que gira em torno da construção da notícia. Seu formato é basicamente o de oficina (workshop), composta por palestras teóricas e exercícios práticos que treinam o executivo para o contato com a imprensa. O "media training" é geralmente dado por jornalistas experientes.

$\mathrm{O}$ treinamento tem a função de criar um bom relacionamento com os jornalistas, o que hoje é hoje fator crítico para a imagem de qualquer empresa. Os profissionais de uma corporação constroem ou destroem a imagem de sua empresa a cada contato com os jornalistas. A lógica do "media training" é que enquanto todo porta-voz tem responsabilidade sobre a imagem da empresa que representa, cabe à empresa treiná-lo e municiá-lo de informações, orientando-o sobre a linha de comunicação a seguir e seus limites. O treinamento costuma durar um dia inteiro e é formatado geralmente para uma pessoa. Mas há formatos para cinco pessoas e até dez pessoas. Para dez pessoas, o "media training" custa por volta de $\mathrm{R} \$ 15$ mil. Os programas são geralmente divididos em três ou quatro etapas, com a primeira parte teórica, sobre como funciona a imprensa, como trabalham os jornalistas, o que é a pauta, o que é notícia, o que é um bom relacionamento com um jornalista, o que o jornalista busca na entrevista e o que o entrevistado deve oferecer, segundo um profissional de assessoria que não quis ter seu nome revelado (2008 informação pessoal $)^{32}$.

"Na parte prática, falamos das armadilhas, que é quando o jornalista diz que vai falar de um assunto, mas acaba levando a entrevista para outro enfoque, outro assunto mais sensível à

\footnotetext{
${ }^{32}$ Informação fornecida por profissional de assessoria de imprensa que não quis se identificar em São Paulo, em entrevista à autora em 2008.
} 
empresa, colocando o entrevistado contra a parede. O treinamento prático não é como aqueles cursos "como falar", "como se comunicar", não é isso, é um treinamento em que você está lá, de repente toca o telefone. '-Presidente, o jornalista da Folha quer falar com o senhor sobre um desastre ecológico que aconteceu...' .Às vezes é um jornalista da Folha mesmo, só que ele é contratado para o media training. O executivo é obrigado a atender na hora. O jornalista faz a entrevista, manda a matéria, e nós discutimos o resultado. Aí pegamos tudo o que foi produzido e analisamos. '-O senhor falou isso, mas o jornalista falou desse jeito, o senhor precisa tomar cuidado com isso, o senhor deixou de falar tal coisa'. Tudo isso é preparado antes pela equipe do media training, mas pega as pessoas de surpresa. Fazemos várias matérias durante o treinamento, inclusive de TV. Contratamos o cinegrafista, ele vai lá, chega de surpresa. Falamos um pouco da postura, roupa. O trabalho é colocá-los contra a parede, eles detestam quando o jornalista faz isso.” (Ibid., 2008).

\subsubsection{O APELO DA ESPECIALIZAÇÃO, OS CURSOS DE ECONOMIA E OS PREMIOS PARA JORNALISTAS}

Dentro das estratégias de abordagem de jornalistas, estão os cursos e os prêmios. Logo no início de suas atividades profissionais, o jornalista que começa a trabalhar na área econômica é apresentado a temas e conceitos que em nada se relacionam com seu cotidiano, a menos que tenha estudado economia. Em 2008, por exemplo, os temas da 
"moda" eram superávit primário, déficit nominal zero, crise subprime, perdas cambiais e derivativos tóxicos.

Pela dificuldade de compreensão imediata das questões econômicas, o jovem jornalista se vê forçado buscar conhecimento específico para conseguir dar conta do trabalho. Cientes desse campo fértil de atuação, inúmeras instituições, com orientação das assessorias, oferecem cursos sobre o mercado de capitais gratuitamente aos jornalistas. Levantamento indicou que em 2007 os principais eram:

*MBA Informações Econômico-Financeiras e Mercado de Capitais da BM\&F (Bolsa Mercantil e de Futuros, desde 2008 chamada BM\&FBovespa).

*Introdução ao Mercado de Capitais da Anbid (Associação Nacional dos Bancos de Investimento).

*Introdução ao Mercado de Capitais da Apimec (Associação dos Analistas e Profissionais de Investimentos do Mercado de Capitais), ex-Abamec (Associação Brasileira dos Analistas do Mercado de Capitais.

*Introdução do mercado de capitais da Ação Jovem do Mercado Financeiro e de Capitais (curso pago, mas oferece vagas gratuitas para jornalistas).

*Análise de Balanços do Instituto de Auditores Independentes do Brasil (Ibracon). 
*Análise de Balanços em Instituições Financeiras do Ibracon.

*Introdução ao Mercado de Ações da Enfoque Informações Financeiras.

Esses cursos passam ao jornalista uma visão positiva sobre o mercado financeiro, mostrando as ideias que regem as leis desse mercado e como os instrumentos financeiros podem gerar lucro aos investidores e benefícios à sociedade. Além disso, nesses cursos os jornalistas conhecem diversos agentes do mercado financeiro, que eventualmente se tornarão fontes das matérias. Os cursos entram para o currículo do repórter, tornando-o um profissional mais valorizado, com salário melhor.

Um aparte deve ser feito ao MBA da BM\&F (desde 2009 a BM\&F tornou-se BM\&FBovespa, resultado da fusão com a Bolsa de Valores de São Paulo). Cada vez mais disputado, trata-se de um curso de um ano e meio, ministrado pela instituição em parceria com a Fundação Instituto de Administração (FIA). Na chamada para o exame seleção, a BM\&F destaca que a FIA é formada por professores da Faculdade de Economia e Administração (FEA) da Universidade de São Paulo (USP), o que revela uma estratégia de legitimação científica. Criado há sete anos, formou mais de 180 profissionais. Uma importante atração do curso é uma viagem aos Estados Unidos, com tudo pago, para mostrar aos alunos as principais Bolsas de Valores e de Mercadorias dos Estados Unidos.

\section{BM\&FBOVESPA abre inscrições do curso de MBA para jornalistas}

A BM\&FBOVESPA está iniciando as inscrições para a turma de 2009 do curso MBA Informações Econômico-Financeiras e Mercado de Capitais, dirigido a jornalistas que atuam na cobertura das áreas de Economia e Finanças. O processo de seleção, que abrange 
entrevista e análise de currículo, será realizado entre novembro e dezembro. O início das aulas está marcado para março de 2009.

O curso é ministrado pela Bolsa, em parceria com a Fundação Instituto de Administração (FIA), formada por professores da Faculdade de Economia e Administração da Universidade de São Paulo (FEA/USP), que é responsável pela parte pedagógica. Criado há sete anos, já formou mais de 180 profissionais de todo o País e conta com o apoio da Associação Nacional de Jornais (ANJ).

Para se inscrever, é necessário que o interessado seja graduado em Jornalismo há mais de três anos e tenha atuado na imprensa, na cobertura de temas econômicos e financeiros, pelo período mínimo de três anos. O curso é composto por oito módulos semanais, um a cada mês, com aulas de segunda-feira a sábado, em período integral, das $8 \mathrm{~h} 30$ às $17 \mathrm{~h} 30$. As aulas serão realizadas na FIA - Unidade Educacional Pinheiros, Rua Navarro de Andrade, 152, em São Paulo.

Ao longo do curso serão apresentadas vinte disciplinas, cujo conteúdo tem como objetivo formar jornalistas que dominem os principais conceitos que envolvem a economia de um país. Entre os temas abordados, estão: os mercados de derivativos e de ações, os processos de globalização, os mercados financeiros locais e internacionais, suas relações com empresas e governos, os elementos de finanças das companhias e dos setores econômicos em que elas atuam.

Além dos conceitos, os participantes terão de conhecer e saber utilizar as informações captadas nos vários mercados, com foco em derivativos e ações. Desta forma, ao final do curso, deverão estar habilitados para detectar e traduzir em informações os panoramas conjunturais, bem como para analisá-los e elaborar cenários futuros alternativos. Como trabalho de conclusão do curso e avaliação final, cada aluno desenvolverá uma monografia.

BM\&FBOVESPA S.A.

Diretoria de Comunicação

Gerência de Imprensa

Telefones: 55113119 2291/ 2450 / 2334

e-mail: imprensa@bmfbovespa.com.br

http://www.bmfbovespa.com.br

Novo Mercado: BVMF3

Figura 2. Convite para o curso BM\&FBOVESPA enviado por email a jornalistas. 
Além dos cursos, há uma ampla oferta de prêmios em dinheiro para jornalistas de finanças, em reconhecimento a matérias que contribuem para o desenvolvimento dos mercados de capitais e de derivativos brasileiro. Levantamento de 2007 indicou que os principais eram:

* Bovespa (hoje BM\&FBovespa).

* Citibank, Prêmio de Excelência em Jornalismo.

*Apimec, para profissional de Imprensa.

*Abecip (Associação Brasileira das Entidades de Crédito Imobiliário e Poupança).

*Comissão de Valores Mobiliários (CVM)/Instituto Brasileiro de Relações com Investidores (IBRI), prêmio Imprensa de Educação ao Investidor no Mercado de Capitais.

*IBCG Itaú, parceria entre o Instituto Brasileiro de Governança Corporativa e o Banco Itaú.

\subsubsection{OS DEPARTAMENTOS ECONÔMICOS}

No noticiário econômico, os departamentos econômicos dos bancos, das corretoras e das consultorias são as áreas que mais oferecem ideias para matérias. A maioria dos departamentos desfruta da autoridade do nome da instituição da qual fazem parte, ao mesmo tempo em que são altamente produtivos, oferecendo uma ampla gama de estudos 
técnicos e comentários aos jornalistas. Não há referencial teórico sobre a influência do departamento econômico das instituições financeiras na imprensa. Mas o dia a dia de uma redação de economia mostra que os estudos produzidos por essas áreas dos bancos estão presentes na rotina dos jornalistas.

Os relatórios, que são vendidos a clientes, chegam diariamente por email aos jornalistas, com comentários de equipes de economistas sobre política econômica e projeções sobre o comportamento do mercado financeiro e das variáveis macroeconômicas (PIB, produção industrial e balança comercial, por exemplo). Os departamentos também oferecem aos jornalistas levantamentos exclusivos sobre temas da economia, que com muita frequência se transformam em matérias. Nos casos em que o jornalista gostaria de receber tal material, mas não recebe, talvez por estar começando na área, uns poucos contatos com assessorias de imprensa ou com os próprios economistas desses departamentos já são suficientes para levá-los a entrar no mailing da instituição.

Sem teoria disponível, a solução metodológica adotada para traçar a relação entre jornalistas e economistas foi entrevistar profissionais dos dois lados. O diretor de um grande banco brasileiro que não quis ter seu nome revelado e nem o da instituição em que trabalha, explicou que os departamentos de economia foram criados para atender a clientes empresariais que necessitam de informações econômicas para planejar as atividades produtivas e financeiras de suas empresas e que pagam caro por elas (2007 informação pessoal $^{33}$. Os economistas tomam dados presentes, como produção industrial, balança comercial, contas públicas, Produto Interno Bruto (PIB), formação bruta de capital fixo etc

\footnotetext{
${ }^{33}$ Informação fornecida por diretor de um grande banco que não quis se identificar em São Paulo, em entrevista à autora em 2007.
} 
para projetar o comportamento da economia nos próximos meses ou anos. Sabendo quanto e se o País vai crescer, o cliente pode decide que tipo de investimento fará. Os departamentos econômicos também analisam o comportamento das empresas negociadas em Bolsa, opinando sobre se é hora de comprar ou vender ações.

Praticamente todos os bancos, corretoras e consultorias têm departamentos de pesquisas e estudos econômicos. Para Lacerda (2006 informação pessoal) a estratégia comunicacional desses departamentos e tornar suas equipes de economistas inteiramente dispostas a atender à mídia, provocando-a com o envio diário desses relatórios, em torno de um objetivo mais amplo que é o de construir espaços nos jornais ${ }^{34}$. Para as assessorias de imprensa, os relatórios significam uma ampla oferta de pautas para os cadernos de economia. O material vem sempre acompanhado pelo nome e o telefone da mesa do economista (Anexo B) que o elaborou, facilitando o acesso e ajudando na construção de laços com os economistas. No geral, as assessorias de imprensa escolhem os jornalistas que receberão o material, mas não raro são os próprios economistas ou as secretárias dos departamentos que incluem os repórteres no mailing depois de um primeiro contato. "Tornou-se cômodo para a imprensa receber essas informações. E a meu ver, analisando essas informações percebemos que são fortemente carregadas do discurso financeiro. Você abre os jornais, vê televisão, ouve rádio..., falou de economia, está associado a finanças. A análise daquele cara que está no jornal, na TV, é claro, é a visão do banco sobre aquela medida" (Ibid., 2006) ${ }^{35}$.

\footnotetext{
${ }^{34}$ Informação fornecida por Lacerda em São Paulo, em entrevista à autora em 2006.

${ }^{35}$ Ibid., 2006.
} 
Assis (2008 informação pessoal) ${ }^{36}$ acredita que os departamentos de economia foram criados para ser a ponte entre as instituições financeiras e a imprensa. Depois do Plano Real (1994), os jornalistas passaram a ser mais procurados por assessorias oferecendo economistas para atuar como fontes. Mas a forma mais comum de contato entre as duas partes vem do departamento econômico, que envia os relatórios à imprensa. Muitos economistas chegam a ligar para as redações perguntando qual o profissional que cuida de determinada área, oferecendo-se para comentar ou sugerir matéria. Isso acontece até mesmo em instituições que têm assessoria de imprensa. Geralmente, após os primeiros contatos, o jornalista já tem os telefones pessoais do economista, o que os torna sempre disponíveis, muito diferente dos empresários, por exemplo, que nunca atendem os jornalistas nos primeiros contatos e dificilmente passam telefones particulares.

Há aparente exceções. Um banco que parece inacessível é o Bradesco, cuja assessoria é uma barreira que só consegue ser transposta por alguns poucos repórteres e colunistas conhecidos. Só que por trás dessa austeridade toda, o banco envia relatórios diários a uma gama maior de jornalistas, incluindo os contatos dos economistas. Se eles não falam "onthe-record", falam "off-the-record", ou seja, o banco não dá opiniões abertamente, mas também não deixa de querer influir no noticiário

Se o critério de credibilidade é um importante componente da relação entre jornalista e fonte, a disponibilidade é provavelmente ainda mais relevante, levada a sério pelas instituições financeiras. Segundo Gans (1979 apud WOLF, 2001:228), fontes que cooperam

\footnotetext{
${ }^{36}$ Informação fornecida por Assis em São Paulo, em entrevista à autora em 2008.
} 
com os jornalistas são mais utilizadas que outras de maior credibilidade, porém menos acessíveis. Por conta dos constrangimentos de horário, o telefone é o contato privilegiado entre jornalista e fontes, conseguindo reduzir em até $80 \%$ do trabalho de apuração do repórter (MORETZSOHN, 2002). E os economistas de bancos atendem aos jornalistas nos fins de semana, nos plantões de feriados e até tarde da noite. Há convites para almoços, encontros informais fora do horário de trabalho, jogos de futebol em camarotes, teatros, shows e até festas. Criam-se relações de confiança e de simpatia às vezes muito difíceis de ignorar, tornando o jornalista ligado a um número pequeno de fontes, impedindo o tãonecessário debate de ideias. 


\section{CAPÍTULO 3}

\section{REFERENCIAL TEÓRICO - 3}

\section{A FINANCEIRIZAÇÃO DO JORNALISMO ECONÔMICO NO BRASIL - 1}

Este capítulo perpassa a história do jornalismo econômico brasileiro, tomando como base o marco teórico já desenvolvido por autores que se dedicaram ao tema. Focará especialmente no processo, iniciado no regime militar inaugurado em 1964, que culminou na financeirização do jornalismo econômico dos anos 1990, consagrando sua maioridade e elevando-o a uma categoria tão importante quando a política.

Em seu início, o jornalismo econômico brasileiro era tímido, mais voltado a atender às necessidades oriundas do perfil agrário-exportador que definira por anos a economia 
brasileira $^{37}$. O regime militar talvez tenha sido o grande impulsionador do noticiário econômico, pois enquanto os assuntos de política eram obrigados a sair dos jornais por conta da ditadura, tomava seu lugar a exaltação do "milagre" econômico ${ }^{38}$. Mas seguindo o processo econômico, a financeirização do noticiário ocorreu de forma mais visível a partir do início dos anos 1990, quando o País passou a ser guiado pelo receituário do "Consenso de Washington" (Capítulo 1).

\footnotetext{
${ }^{37} \mathrm{Na}$ virada do século XIX para o século XX, a matéria prima do noticiário brasileiro era a política. O noticiário econômico correspondia a algumas poucas páginas, lidas por especialistas de alguns setores. "Eram páginas dedicadas ao café, ao preço do café, ao comércio do café, à importação e exportação de café" (informação verbal fornecida por Rocha em São Paulo, em entrevista à autora em 2007). Em O Estado de S.Paulo, o ponto de partida para a instituição de uma pauta econômica mais consolidada foi dado pelo alemão Geraldo Banas, na esteira da Segunda Guerra. Em 1945, ele entrou para o jornal e em 1946, junto com Frederico Heller, criou a seção de economia do Estadão. Em 1949, o jornal lança seu Suplemento Comercial e Industrial, semanal. É atribuído a esse suplemento uma das primeiras manifestações de um jornalismo econômico um pouco mais consolidado (QUINTÃO, 1987:170) e de forte conteúdo estrangeiro, sobretudo norte-americano.

No Grupo Folhas, os temas econômicos passaram a aparecer mais a partir da incorporação a seu quadro de jornalistas, no final dos anos 1930, do advogado Mário Mazzei Guimarães, que escrevia sobre temas de agropecuária. Por volta de 1950, a Folha também tinha repórteres voltados exclusivamente para temas econômicos, que escreviam, sobretudo, matérias analíticas.

Um episódio à parte é o surgimento da Gazeta Mercantil (criada em 1920, na forma de boletim diário econômico e financeiro) como um jornal de negócios, que vai despertar os grandes jornais para o valor contido na informação econômica. Em 1934, o chamado Boletim Diário de Informações da Gazeta Mercantil e Industria", na época propriedade do italiano Pietro Pardini, foi adquirido pela família Levy, que já tinha experiência em publicações na área, com o Boletim Comercial Levy, criado em 1929, e a Revista Financeira Levy, criada em 1931 (LACHINI, 2000:66). Passou a se chamar Gazeta Mercantil, Comercial, Industrial e Financeira e foi a grande escola de jornalismo econômico do Brasil.

38 O período ficou conhecido como "milagre econômico" brasileiro em alusão aos "milagres" alemão e japonês das décadas de 1950 e 1960, marcados por forte crescimento (In: DICIONÁRIO HISTÓRICOBIOGRÁFICO BRASILEIRO- CPDOC- Fundação Getulio Vargas. http://www.cpdoc.fgv.br/dhbb/verbetes_htm/3388_6.asp). Resultou da forte liquidez internacional promovida pelos petrodólares dos países produtores de petróleo, quando países em desenvolvimento como o Brasil foram estimulados por organizações multilaterais a contrair empréstimos vultosos. Com esses empréstimos, foram fortes os investimentos estatais em siderurgia, petroquímica, construção naval e geração de energia elétrica. No período, a construção civil cresceu a uma taxa média anual de $15 \%$, a produção de bens duráveis de consumo, $23.6 \%$, e o de bens de capital $18.1 \%$. A inflação oscilou entre $15 \%$ e $20 \%$ ao ano. Esses recursos financiaram o crescimento do País, mas sem que fossem adotadas políticas de distribuição de renda para não derrubar a necessária poupança nacional. A mais famosa e controversa frase de Delfim Netto, aquela que teria marcado o "milagre", refletiu o que ele pensava sobre a distribuição de renda. "É preciso aumentar o bolo (no caso, a renda), para depois reparti-lo". A palavra de ordem foi arrocho salarial.
} 


\subsection{NELSON WERNECK SODRÉ, UMA RESSALVA}

Antes de iniciar o capítulo, uma constatação. Publicado pela primeira vez no fim dos anos 1960, a obra História da Imprensa no Brasil, de Nelson Werneck Sodré, referência principal sobre o tema, não dedica praticamente um único parágrafo ao jornalismo econômico, o que só fez confirmar a vertente política do noticiário brasileiro. Foi apenas na quarta edição do livro, de 1999, que Sodré escreveu um capítulo novo, muito mais uma reflexão do que uma cronologia, como que para dar conta da crescente importância da economia na política e dos temas econômicos na imprensa.

No capítulo, escrito poucos meses antes de sua morte, Sodré disse que ao passar para a etapa industrial, o jornalismo serviu predominantemente aos anunciantes e menos às necessidades do leitor. "Todos os grandes jornais, hoje, apóiam o neoliberalismo, e o que eles informam não merece confiança. Há um profundo divórcio entre o que o público pensa, acredita e necessita e aquilo que a grande imprensa veicula. [...] Quando a imprensa, como aqui e agora, modula um coro repetitivo de louvação ao neoliberalismo, está claro e evidente que perdeu sua antiga característica de refletir a verdade" (SODRÉ, 1999:XII).

Sodré afirmou que o que se chama de inexorável submissão ao neoliberalismo nada mais foi do outra forma histórica de se enganar os cidadãos. "Os embustes históricos apenas mudam de forma. E a imprensa desempenha nesse processo de deformação papel importante, coadjuvando os meios de massa. Quem controla a imprensa e os meios de massa não precisa mais de golpes militares" (SODRÉ, 1999:XIII) 


\subsection{O INÍCIO DA FINANCEIRIZAÇÃO?}

Foi a partir da segunda metade dos anos 1950 que começou a se praticar no Brasil um jornalismo mais voltado a temas econômicos para além da agricultura, dentro de um processo intimamente ligado à reorganização do capitalismo em âmbito mundial, com a consolidação de multinacionais estrangeiras e alguns grandes bancos internacionais como os grandes detentores do poder econômico. Significa dizer que os anos JK (1956-1961) ${ }^{39}$ foram o grande divisor de águas dessa cronologia (RESENDE, 2003:88) ${ }^{40}$. A entrada de capital estrangeiro produtivo promovida pela política de Juscelino Kubitschek também promoveu a expansão do mercado publicitário no País. Como a receita da venda em banca nunca fora suficiente para bancar as equipes e os custos de produção, os jornais passaram a necessitar cada vez mais de anunciantes. E a indústria de bens de consumo que aqui se instalara respondeu positivamente às necessidades de receita dos jornais. Essa virada mercadológica foi uma das principais mudanças da imprensa no período.

\footnotetext{
${ }^{39}$ Durante seu mandato, o presidente Juscelino Kubitschek pôs em prática seu Plano de Metas, de crescimento de "cinquenta anos em cinco". O plano era fortemente influenciado pela política de substituição de importações da Cepal (Comissão das Nações Unidas para a América Latina e o Caribe), que visava a criar no País um parque industrial forte e variado, capaz de suprir as necessidades do mercado interno, permitindo um excedente exportador. Tentou-se aliar desenvolvimento com abertura do País às multinacionais, detentoras de tecnologia e geradoras de emprego, que ajudariam também a criar um mercado consumidor local. JK criou o Grupo Executivo da Indústria Automobilística, setor que alavancaria a industrialização do Brasil sustentado pelo investimento estrangeiro. Nesse período, também se instalou no País a indústria estrangeira de bens de consumo, e, junto com as grandes multinacionais, vieram também as assessorias de imprensa. Muito utilizadas pelas montadoras nos anos 1950 como ferramenta de divulgação de produtos e de criação de imagem, mais tarde elas seriam apropriadas pelo regime autoritário, incentivando a cobertura do milagre econômico (RESENDE, 2003:88).

40 Ainda nesse período, surge na cena jornalística Aloysio Biondi, um dos expoentes da equipe de profissionais especializados em economia que a Folha conseguiu reunir. Biondi viria a ser uma das maiores, se não a principal, referências do jornalismo econômico brasileiro. Atuou por 44 anos até sua morte, no ano 2000. É considerado uma das grandes resistências à predominância do pensamento único na imprensa brasileira. Dada a sua importância, talvez fosse possível contar a história do jornalismo econômico apenas pela trajetória profissional de Biondi.
} 


\subsection{A DUPLA CAMPOS-BULHÕES E O MILAGRE ECONÔMICO}

No final dos anos 1960, dentro do regime militar, o jornalismo econômico começa a se consolidar como uma área diferenciada da atividade profissional. Os militares tiraram os temas políticos do noticiário, ao mesmo tempo em que surgia com força um mercado de capitais especulativo, na década de 1970, com o fim do sistema de Bretton Woods. Os jornais prestigiaram, primeiramente, o caráter autoprofessado como modernizador da dupla Roberto Campos e Octávio Gouveia de Bulhões (1964-1967), no Planejamento e na Fazenda, respectivamente. Dentro da mítica de modernidade, a dupla introduziu na imprensa temas inspirados nas teses neoliberais norte-americanas, como a necessidade de reestruturação das relações trabalhistas, que acabou levando a demissões em massa e à recessão 1964-1966, sob o pretexto de domar a escalada da inflação. "Mas o jornalismo econômico desempenhará um papel não apenas de informante e analista dos negócios econômicos e financeiros, mas vai agir ainda como aliciador da consciência nacional e viabilizador, como tal, de uma rápida e segura reprodução do capital, como queriam as elites"(QUINTÃO, 1987:13).

Roberto Campos e Gouveia de Bulhões adotaram ideias e discurso técnicos. Campos transformou-se em porta-voz do governo para a área econômica, convicto da eficácia de teses modernizantes e estrangeiras. Ele foi o principal representante do Brasil na Comissão Mista Brasil-Estados Unidos, ganhou o apelido de Bob Fields (seu nome em inglês) e 
carregou a pecha de entreguista dos interesses brasileiros para os norte-americanos. Contraatacou com artigos em jornais e fornecendo informações a seus amigos jornalistas que trabalham em grandes jornais. Campos montou sua assessoria de imprensa ao assumir o Planejamento, quando sucedeu ao economista Celso Furtado, fundador da Cepal (a então influente comissão das Nações Unidas para a América Latina e o Caribe) e ex-ministro no governo João Goulart (1961-1964), para favorecer a legitimação das novas diretrizes econômicas do governo e garantir maior respeito às suas ideias. Outra de suas táticas foi a criação do Instituto de Pesquisas Econômicas (Ipea), contratando cerca de 100 jornalistas para compor o Grupo de Redação e divulgar material simpático à política governamental.

Na TV Rio, a de maior audiência na época, Campos criou o programa $O$ assunto é política, por meio do qual buscava dar maior racionalidade técnica às discussões econômicas. Era patrocinado pela montadora Chrysler e pela Standard, agência de publicidade norteamericana.

Delfim Netto, que substitui Bulhões na Fazenda em 1967, também montou para si uma assessoria de imprensa, e assim proliferam as assessorias de imprensa nos ministérios, autarquias e empresas públicas vinculadas à área econômica (QUINTÃO, 1987). No período Delfim, que durou até 1974, a imprensa convencional dedicou-se a exaltar o Produto Interno Bruto (PIB), que cresceria a taxas anuais médias superiores a 10\%, numericamente comprovando o sucesso do desempenho econômico do País (ainda que à custa de um alto endividamento externo e do aumento da concentração de renda e da pobreza). 
A máquina oficial bombardeava os jornais com notícias positivas sobre o crescimento da economia, dos investimentos e da Bolsa de Valores $^{41}$. Cafardo disse que era muito tranquilo fazer cobertura econômica naquele período, porque a imprensa era pró-governo e raramente sofria repressão, enquanto outras áreas dos jornais eram censuradas (2008 informação pessoal $)^{42}$. O que se viu no período foi a ampliação das equipes de economia em jornais de todo o País, enquanto as editorias de política emagreciam.

Na época do "milagre", havia basicamente três tipos de fontes regulares, com predomínio das autoridades. Delfim Netto costumava receber às segundas-feiras, bem cedo, os principais editores dos jornais e revistas para conversas reservadas na sede do Ministério da Fazenda, em São Paulo, antes de voar para Brasília. Esses encontros funcionavam para balizar a cobertura de economia, indicar medidas que viriam e, na ponta oficial, para sentir a temperatura da política medida pelo termômetro dos jornalistas. Costumavam participar essas reuniões Rolf Kuntz, Robert Appy, Roberto Muller e José Roberto Guzzo, entre outros (Ibid., 2008).

\footnotetext{
41 Outra mudança importante no discurso jornalístico aconteceu no início dos anos 1970, quando os professores de economia começaram a fazer parte do cotidiano da revista Exame. A publicação quinzenal de economia e negócios da Editora Abril fez em 1973 um convênio com a Fipe (Fundação Instituto de Pesquisas Econômicas, formada por professores da Universidade de São Paulo) em que a Abril pagava algumas bolsas de pós-graduação em economia e, em troca, professores e pesquisadores da Fundação se reuniam mensalmente com os jornalistas para discutir conjuntura econômica, entre eles Affonso Celso Pastore, João Sayad, Fernando Homem de Mello, Roberto Macedo, Guilherme Dias e José Roberto Mendonça de Barros. Muitos eram professores universitários que estavam chegando de Yale, Chicago e Princeton, universidades norte-americanas (RESENDE, 2003:142). Esses economistas, que mais tarde desembarcariam no governo, não tinham canal aberto na mídia. Mas com essa reunião mensal, descobriram como falar com a imprensa. Aprenderam os interesses dos jornalistas, que pautavam as reuniões, enquanto os jornalistas entravam em contato com o discurso e o pensamento mais técnico e científico dos professores.
}

${ }^{42}$ Informação fornecida por Cafardo em São Paulo, em entrevista à autora em 2008. 
O segundo bloco de fontes do noticiário de economia eram os empresários. Imbuídos do espírito oficial, rasgavam elogios à política econômica do governo. A Federação as Indústrias do Estado de São Paulo (Fiesp) era a principal representante do setor.

Um terceiro bloco eram os economistas. Havia algum espaço para os que contestavam a política econômica e a má distribuição de renda. Entre eles estavam Celso Furtado, o principal crítico da política econômica do regime militar, Luiz Carlos Bresser-Pereira, José Serra, Eduardo Suplicy e João Sayad, todos ligados à academia. Não havia, na época, nenhum economista de banco entre as fontes regulares dos jornais, até por razões óbvias: o governo não admitiria críticas por parte dos banqueiros. $\mathrm{O}$ banco mais crítico ao regime poderia sofrer retaliações (Ibid., 2008).

O "milagre" começou a cambalear com o primeiro choque do petróleo, de 1974, quando houve forte aceleração inflacionária e a balança comercial brasileira passou a registrar déficits expressivos por conta da importação de petróleo e combustíveis. Os níveis de crescimento médio entre 1974 e 1979 caíram para 6.5\%, chegando a 4\%. A dívida externa, que chegaria a US\$90 bilhões, consumia 90\% das receitas exportadoras. No final da década de 1970, com o segundo choque do petróleo e a mudança na política monetária dos Estados Unidos, que elevaram os juros para controlar a inflação, o endividamento externo promovido pelo milagre cobraria um preço alto.

Em 1982, México e Brasil declararam moratória da dívida externa. O capital internacional se tornou escasso e caro para os países da periferia. No Brasil, a moratória postergou 
projetos de investimentos e colocou o País em um estado de estagnação econômica. As decorrentes negociações das dívidas com o Fundo Monetário Internacional (FMI), o Banco Mundial e o Banco Interamericano de Desenvolvimento (BID), para obtenção de novos empréstimos, pressionaram os governos, forçando a movimentação das economias em direção à liberalização das restrições aos fluxos de capital e de mercadorias e serviços (BAUMANN. In: LACERDA, 2000). Essas instituições exigiam aumento de impostos, desvalorização de moedas e redução de gastos governamentais - o que permitiria aos governos pagar suas dívidas.

O jornalismo não passaria ao largo das mudanças monetárias do período 1970-1980. As crises externas, o esvaziamento forçado dos assuntos de política e a inflação em alta acabaram por tornar a economia o núcleo temático do noticiário a partir de meados dos anos 1970. Para as elites empresariais e financeiras, dentro de um cenário de alto risco, a informação econômica tornou-se mais relevante para a tomada de decisões (KUCINSKI, 1996:14). Para o leitor não-especializado, o jornalismo econômico assumiu a função de explicar os impactos dos juros altos e da inflação sobre alugueis, salários, emprego e prestações. Nos anos 1970, também houve crises de abastecimento que preocupavam a sociedade. Os jornais refletiram isso e começaram a cobrir agricultura mais com esse enfoque. Com a criação do Jornal da Tarde, no início dos anos 1970, a notícia economia ganharia um perfil mais de atender ao consumidor, inclusive nas aplicações financeiras, com sessões do tipo "entenda", “dicas" ou "ABC”. O jornalista Joelmir Beting lançou a própria coluna diária, traduzindo o "economês" técnico. Foram criadas, com grande ênfase, seções do tipo "Seu Dinheiro", voltadas para a classe média que sonhava com a casa própria e começava a fazer aplicações financeiras. 
Diante das mudanças estruturais em curso, as direções dos jornais começaram a achar os economistas acadêmicos exageradamente teóricos. Os jornalistas queriam informações de pessoas mais envolvidas com o cotidiano do nascente mercado financeiro, segundo Rocha (2007 informação pessoal) ${ }^{43}$. Nesse período, uma série de instituições financeiras nãobancárias ganhou corpo, como as corretoras e as distribuidoras de títulos e valores mobiliários, as DTVM. Além disso, com as confusões criadas por planos econômicos complicados, com tabelas, tablitas, conversores, redutores e impostos extraordinários, os jornais precisavam de fontes para explicar tudo isso. Foi assim, para dar conta de novas exigências do jornalismo econômico, que os economistas de bancos passaram a aparecer no noticiário. "Eles começaram a chegar aos jornalistas porque eram muito ativos, jovens e sem medo de falar. Não eram como os banqueiros, figuras reservadas, misteriosas, discretas e silenciosas. Eles viviam nos bares que os jornalistas frequentavam, na noite, viviam indo em coisas de jornalistas, vivam chamando os jornalistas para conversa, para café da manhã... então tinham muito mais condições de se tornarem fontes da imprensa" (Ibid., 2007).

Com a renegociação da dívida externa no âmbito do Plano Brady $^{44}$ de 1989, os investimentos estrangeiros começaram a retornar ao País, basicamente por meio da

\footnotetext{
${ }^{43}$ Informação fornecida por Rocha em São Paulo, em entrevista à autora em 2007.

${ }^{44}$ Em março de 1989, após as moratórias, foi anunciado pelo secretário de Tesouro dos EUA Nicholas F. Brady um plano para renegociar a dívida externa de países em desenvolvimento, mediante a troca por papeis novos. Esses novos títulos contemplavam o abatimento do encargo da dívida, através da redução do seu principal ou pelo alívio nos juros. Além de emitir os bônus, os países deveriam promover reformas liberais em
} 
aquisição de títulos do governo. A entrada de recursos foi reforçada com as primeiras medidas de liberalização do fluxo de investimentos financeiros de 1990, no governo Collor. Nesse meio tempo, as instituições financeiras começaram a contratar assessorias de imprensa e, em paralelo, começou a consolidação da cultura de departamentos econômicos, que produziam estudos e projeções para clientes. "Eu mesmo montei uma empresa de comunicação nessa época, a XYZ, cujo primeiro cliente foi a Bolsa de Mercadorias - ainda não existia a BM\&F. As empresas de comunicação estavam começando, e o mercado financeiro estava interessado em se comunicar. Houve uma coincidência de necessidades" (Ibid., 2007).

Aos poucos, os economistas do mercado financeiro ganharam importância tamanha no noticiário que não perderiam posição como porta-vozes do pensamento econômico por décadas à frente. Liberado de algumas amarras regulatórias, o setor financeiro impulsionou um modelo econômico movido a oferta de crédito com juros altos.

De início, fontes do mercado financeiro entraram no noticiário prioritariamente para falar de instrumentos de aplicações financeiras contra a corrosão inflacionária. Com o Plano Real lançado em 1994, durante o governo Itamar Franco e sob o comando de Fernando Henrique Cardoso na Fazenda, aquele tipo de jornalismo de serviço financeiro entrou em declínio com a redução da inflação. Uma vez controlados os preços, o noticiário passou a enfatizar aspectos mais ideológicos do neoliberalismo, como mudanças nas políticas monetária e fiscal, corpo de supostas estratégias de desenvolvimento e fundamentais à seus mercados. Os bônus do Plano Brady ficaram conhecidos como bradies (BATISTA JUNIOR; RANGEL, 1994). 
entrada de investimento estrangeiro. Naquele momento, o apoio da imprensa seria fundamental para legitimar questões ideológicas, como a redução do papel do Estado na economia, com privatizações, abertura comercial, financeira, juros altos e câmbio flutuante. A tecnologia avançava mundialmente, permitindo a integração global das bolsas de valore, enquanto as aplicações financeiras se sofisticaram com os derivativos. A obtenção de ganhos no mercado financeiro passou a ser muito maior do que com a atividade produtiva, e muitas grandes empresas deixaram de investir em suas atividades para aplicar no mercado financeiro. O noticiário concentrou-se em comportamento de bolsa, dólar e juros, enquanto as notícias de negócios passaram de estratégias empresariais para a divulgação dos lucros das empresas de capital aberto negociadas em bolsa, de forma que os novos acionistas dessas empresas pudessem acompanhar seus investimentos.

\subsection{O PLANO REAL E A IMPRENSA}

Desde o regime militar, o Brasil vinha passando por mudanças profundas de política econômica, com espasmos de liberalização que só viriam a se consolidar a partir de 1994. Naquele ano, entrou em vigor o Plano de Estabilização Econômica do governo Itamar Franco - o Plano FHC ou Real - pelas mãos do então ministro da Fazenda, Fernando Henrique Cardoso, que depois sucedeu Franco na Presidência por dois mandatos consecutivos (1995 a 2002).

No noticiário, o que se viu foi o avanço das fontes reprodutoras das políticas econômicas do "Consenso de Washington", que chegaram à imprensa como sendo detentoras do único 
e melhor modelo de desenvolvimento: analistas de bancos, administradores de fundos de investimento, consultores e operadores do mercado financeiro, mas sobretudo membros do próprio governo. Fernando Henrique achava que o sucesso de seu plano dependeria em grande parte de um substancial esforço de comunicação. Entre os integrantes da equipe que trabalhava na preparação do Real, era pesadelo recorrente a possibilidade de o plano vir a ser prejudicado por falhas na comunicação inicial das medidas ao público, como havia acontecido com o Plano Collor (março de 1990), quando a equipe comandada por Zélia Cardoso de Mello tropeçava nas respostas dadas aos questionamentos dos jornalistas, aumentando as desconfianças sobre o duvidoso e polêmico plano.

Preocupada com essas possíveis falhas de comunicação, a equipe de Fernando Henrique chamou a jornalista Maria Clara R.M. do Prado para traçar toda a estratégia de divulgação do Real, um plano cheio de etapas e que deveria ser apresentado de forma gradual. Maria Clara deve ter sido escolhida porque era uma jornalista conhecida e experiente. Havia feito por nove anos em Brasília a cobertura dos assuntos relacionados a política monetária, normas do sistema financeiro, vários processos de renegociação da dívida externa, discussões que envolveram os programas de ajuste assinados pelo País com o FMI e às inúmeras tentativas, até então frustradas, de estabilização econômica (PRADO, 2005).

Prado (2005) contou que para que pudesse fazer um bom trabalho na divulgação do Real ela precisaria ter acesso a todas as informações, além de ser aceita como participante em todas as reuniões da equipe econômica. As exigências foram aceitas, e as reuniões da equipe econômica passaram a ser acompanhadas pela jornalista. Naquele momento da política brasileira, depois do fiasco do governo Collor, o que estava em jogo era algo muito 
maior do que a estabilização econômica. Não podia haver risco de desconfiança nem tropeços, já que o Real também garantiria a consolidação no poder de um modelo econômico sintonizado com a globalização e a modernidade, condições que o PSDB, partido do então ministro da Fazenda, considerava fundamentais para tirar o País do atraso e se beneficiar da avalanche de recursos financeiros que buscava lucro (PRADO, 2005). Para isso, as altas taxas de juros do Real seriam fundamentais.

A apresentação do Real a imprensa foi um acontecimento elaborado minuciosamente. Além do café da manhã seguido por entrevista coletiva, foi organizado um esquema especial de workshops aos jornalistas. A equipe que elaborou o plano foi dividida em cinco grupos para atender à imprensa, cada um com pelo menos dois economistas e técnicos do governo. Tudo isso fora acertado e comunicado previamente com as empresas jornalísticas. Houve distribuição farta de material: a íntegra da Medida Provisória do Real e da exposição de motivos, um resumo da MP com as principais medidas em destaque, além de uma cartilha do plano com os pontos mais importantes do que seria a adoção de uma nova unidade monetária, a URV, que faria a transição para o Real. 


\section{裳: FOLHA DE S.PAULO

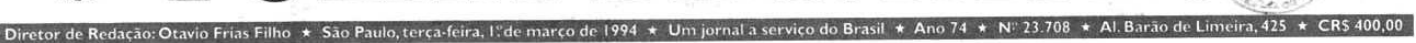
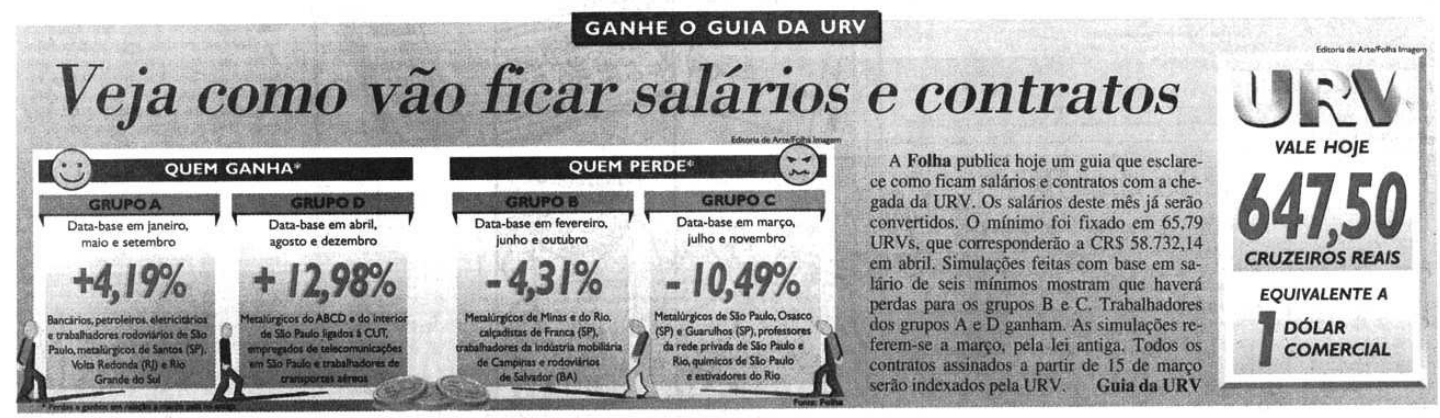

\section{Governo lança URV e partidos preparam mudanças no plano}

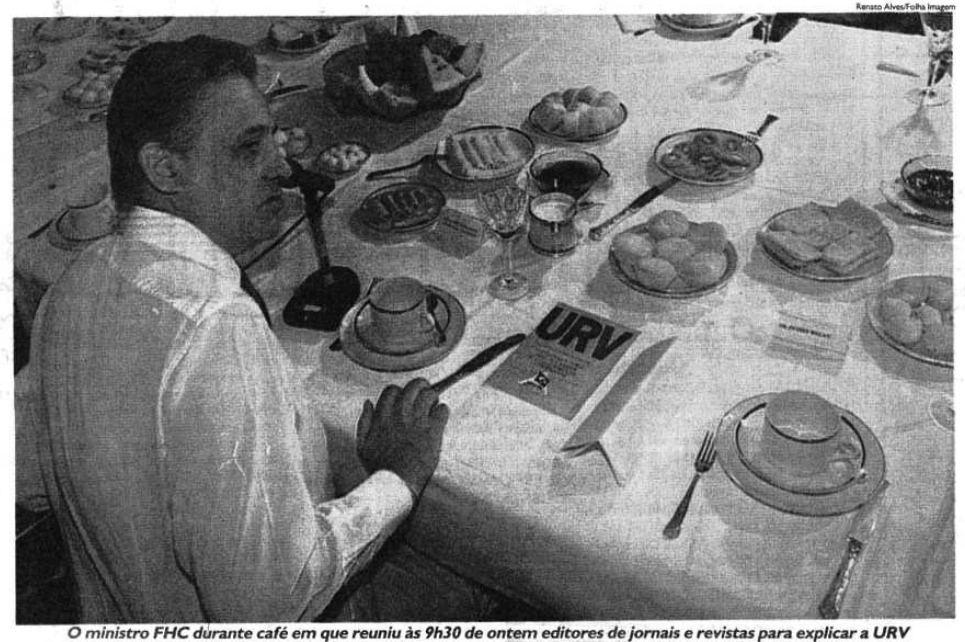

$\star$ Centrais articulam greves para protestar contra perdas salariais

$\star$ Ministério convoca empresas para explicar reajustes de preços

A equipe econômica apresentou ontem o Plano FHC. Foi publicada medida provisória que institui a URV (Unidade Real de Valor), indexador que será base para a nova moeda, o real, sem data de implantação definida. Os principais partidos se dispõem a aprovar o plano, mas querem * mudanças. O PMDB e os partidos de esquerda pretendem incluir ganhos para o salário mínimo e a reposição de perdas salariais. A inclusão de mecanismos de controle de preços para casos de abusos nos primeiros 15 dias do plano conta com apoio de quase todos os partidos. O governo vai convocar empresários responsáveis pelos produtos da cesta básica para explicar aumentos. Centrais sindicais preparam paralisações contra perdas salariais. $\mathrm{O}$ presidente da Fiesp, Carlos Eduardo Moreira Ferreira, disse que o plano deve ser apoiado porque "a inflação é o pior mal da sociedade". A MP instituiu multa para empresas que demitirem funcionários sem justa causa durante a vigência da URV. FHC informou ao PSDB que está disposto a deixar o cargo para preparar sua candidatura à Presidência.

Figura 3. Ministro Fernando Henrique Cardoso recebe editores da imprensa escrita em café da manhã para falar sobre o Plano Real (FSP, 1/3/1994). Reprodução fotográfica pelo Acervo do Estado de São Paulo.

Com o lançamento do plano, os economistas do Plano Real passaram a realizar quinzenalmente mesas-redondas de entrevistas com seletos grupos de jornalistas na sede do Banco Central no Rio, em Brasília e em São Paulo. O objetivo era facilitar o entendimento de tudo o que se relacionava ao plano de estabilização. Procuravam tirar dúvidas e dar 
explicações sobre pontos que os jornalistas considerassem importantes naqueles primeiros meses de vigência da unidade monetária e posteriormente do Real.

Esses encontros só podiam mesmo ser realizados com um grupo seleto. Os economistas do Real não conversavam com os jornalistas que faziam a cobertura diária da Fazenda e do Banco Central. Consideravam-nos, na média, despreparados e ignorantes. Os encontros seletivos eram muito técnicos, com muito número e cordialidade, estrategicamente reunindo a credibilidade do discurso técnico com disponibilidade quinzenal. Os jornalistas recebiam informações econômicas, cifras, prognósticos e tabelas. "Os economistas do Real, na sua esmagadora maioria, preferiam pensar e escrever a falar. Nunca se sentiram muito à vontade com a mídia. O ponto de vista quase unânime da equipe era de que a mídia desgasta, deturpa, e ainda por cima é burra. Os jornalistas, para aqueles economistas, padecem de uma deficiência crônica de raciocínio. São incapazes de entender as tecnicalidades envolvidas nas questões econômicas" (PRADO, 2005:238).

$\mathrm{Na}$ visão que tinha de si próprio, reproduzida amplamente pelos jornalistas, Fernando Henrique se colocaria como o candidato presidencial que vinha em defesa da entrada do Brasil no primeiro mundo, por meio da liberalização econômica, mas com profundas preocupações sociais. Sua frase "a estabilidade é a mais eficaz política de distribuição de renda que o governo pode fazer" serviria para legitimar o plano que adotava as premissas financistas do "Consenso de Washington". 
Do Real para cá, também começou a crescer o jornalismo financeiro de negócios, acompanhando a popularização do mercado financeiro. Os balanços das companhias passaram a ocupar primeiras páginas dos jornais, assim como notícias sobre fusões e aquisições. O jornalismo de negócios passou a se misturar com o acompanhamento do mercado financeiro, e foi nesse ambiente que surgiu no ano 2000 o Valor Econômico, diário de economia e negócios resultante de parceria entre Folha e $O$ Globo.

\subsection{O NOTICIÁRIO EM TEMPO REAL ${ }^{45}$}

Os conceituados jornais Financial Times (Reino Unido) e The Wall Street Journal (Estados Unidos), além da revista britânica The Economist, foram órgãos de imprensa centrais no movimento de financeirização da mídia global (FURTADO, 2000:39). Mas efeito ainda maior tiveram as agências noticiosas. Na década de 1970, houve um crescimento vertiginoso do mercado desregulado do eurodólar, o que levou as principais agências de informação econômica, AP-Dow Jones (Estados Unidos), Reuters (Reino Unido) e Bloomberg (Estados Unidos), a investir pesadamente em tecnologias que permitissem aos agentes econômicos acompanhar mais agilmente o ambiente de cada moeda, taxas de juros e de inflação. Como os mercados oscilavam violentamente, houve grandes ganhos especulativos, e a velocidade da tomada de decisão baseada na informação passou a ter

\footnotetext{
${ }^{45}$ Kucinski (2004:88) chama a atenção para a denominação "tempo real". Para ele, o termo se insere na categoria de conceitos-fetiche, ou falsos conceitos, de Umberto Eco (1976 apud KUCINSKI, 2004:88) e está associado a uma suposta nova modalidade de jornalismo, chamada também de online. "Nesse caso, tenta-se dar conotação de absoluta novidade a um processo muito antigo de transmissão ao vivo, que sempre foi a característica do rádio, do telégrafo e de seus derivados, como o telex e agora o fax."
} 
valor monetário (KUCINSKI, 2004:94) ${ }^{46}$. Os noticiários eletrônicos em tempo real, criados para atender às necessidades do mercado financeiro, se configuraram como um lucrativo mercado para algumas das tradicionais agências noticiosas ${ }^{47}$.

Essa forma de circulação do capital global que se intensificou no mundo todo na década de 1990 e que trouxe dinheiro estrangeiro para o Brasil, refletiu a convergência, iniciada na década anterior, entre a desregulamentação global do sistema financeiro, uma das principais bandeiras do governo Reagan nos Estados Unidos e a disponibilidade de novas tecnologias de informação e de gerenciamento de ativos financeiros. Esse encontro transformou a natureza do mercado de capitais. Pela primeira vez, ele seria global, unificado, funcionando o tempo todo e com grande velocidade de transações.

\footnotetext{
${ }^{46}$ Com a crise do dólar de 1971, na qual se quebraram as paridades fixadas no acordo monetário de Bretton Woods, tornou-se fundamental para os bancos o recebimento de informações rápidas sobre a moeda de cada país. A Reuters introduziu um sistema de fechamento de negócios por via eletrônica, atraindo apenas fundos de pensão. Em 1981, graças às novas tecnologias, a Reuters ampliou o produto, permitindo que o fechamento de negócios financeiros pelos assinantes no mesmo terminal em que recebiam as informações. O meio de informação tornou-se o próprio mercado (KUCINSKI, 2004:95).

${ }^{47}$ A história das grandes agências de notícias coincide com a própria história dos impérios econômicos, dos quais foram braços importantes de informação. Três agências de notícias europeias dividiram o mundo em três territórios por mais de 50 anos a partir de suas criações. A Havas, criada em 1835, deu origem à francesa Agence France Presse (AFP) e ficou com América Latina, Itália, França, Portugal, o Oriente e a Indochina. Para a britânica Reuters (inaugurada em 1851), couberam o Império Britânico, a Holanda e suas colônias, a Austrália, as Índias Orientais e o Extremo Oriente. A alemã Wolff (1849) ficou com a Europa central e setentrional. "Nesta série de associações concluída em 1870 entre as agências europeias, o grande mercado dos Estados Unidos foi deixado de fora, considerado território neutro" (CARDEAL, 2003:69). Esse movimento foi a eclosão de um mercado de informação pensado em âmbito mundial orientado por interesses geopolíticos (MATTELART, 2000 apud CARDEAL, 2003:47-64). A norte-americana Associated Press (AP) foi lançada em 1848 e a United Press International (UPI), em 1907.

A Primeira Guerra (1914-1918) enfraqueceu as agências europeias, e as norte-americanas assumiram o controle da distribuição da informação para os jornais da América Latina. Entre 1930 e 1950, a região foi o foco da expansão das agências noticiosas e das agências de propaganda e de pesquisas de mercado/opinião dos Estados Unidos. Na retórica da Guerra Fria, na década de 1950, o terceiro mundo (conceito surgido nessa fase) era algo a ser integrado, modernizado e desenvolvido para não cair sob a influência de Moscou (CARDEAL, 2003:72).
} 
Com um mercado financeiro crescente e se popularizando, o jornalismo brasileiro também entraria no mundo das agências de informação em tempo real para o mercado financeiro. $\mathrm{O}$ ponto de partida foi dado pela Broadcast, hoje chamada de $A E$ News $^{48}$, da Agência Estado Ltda, empresa do Grupo Estado, e que em meados dos anos 1990 teve dois novos braços: o AE Empresas e Setores, que acompanha as empresas de capital aberto listadas em Bolsa de Valores, e o AE Agro, para os investidores em negócios com commodities agrícolas e grandes produtores rurais. A Agência Estado é a única que domina o mercado de notícias tempo real em um país. Em todos os outros países, esse mercado é detido por Reuters, Bloomberg ou Dow Jones.

\footnotetext{
${ }^{48}$ Em 1990, a Agência Estado adquiriu a empresa de teleinformática Broadcast, que transmitia em tempo real para o computador dos assinantes apenas cotações das bolsas de valores nacionais e estrangeiras. A empresa Broadcast havia sido fundada em 1988 pelo economista Luís Carlos Mendonça de Barros, que dez anos depois se tornaria ministro das Comunicações de Fernando Henrique Cardoso, e pelo empresário Roberto Giannetti da Fonseca, que também participou do governo FHC. Mendonção, como ficou conhecido o exministro por conta de sua falta de gentileza no trato com os jornalistas, é empresário do mercado financeiro, dono de gerenciadora de ativos (asset management) e de corretora.

A introdução de notícias e análises ao serviço de bolsas foi o filão percebido pela Agência Estado para explorar a demanda do mercado financeiro por informações, contribuindo para aumentar a margem de acerto dos investidores, ganhando a confiança dos assinantes e fazendo parte dos hábitos dos operadores, chegando ao patamar de parceria (SILVA, 2002).
} 


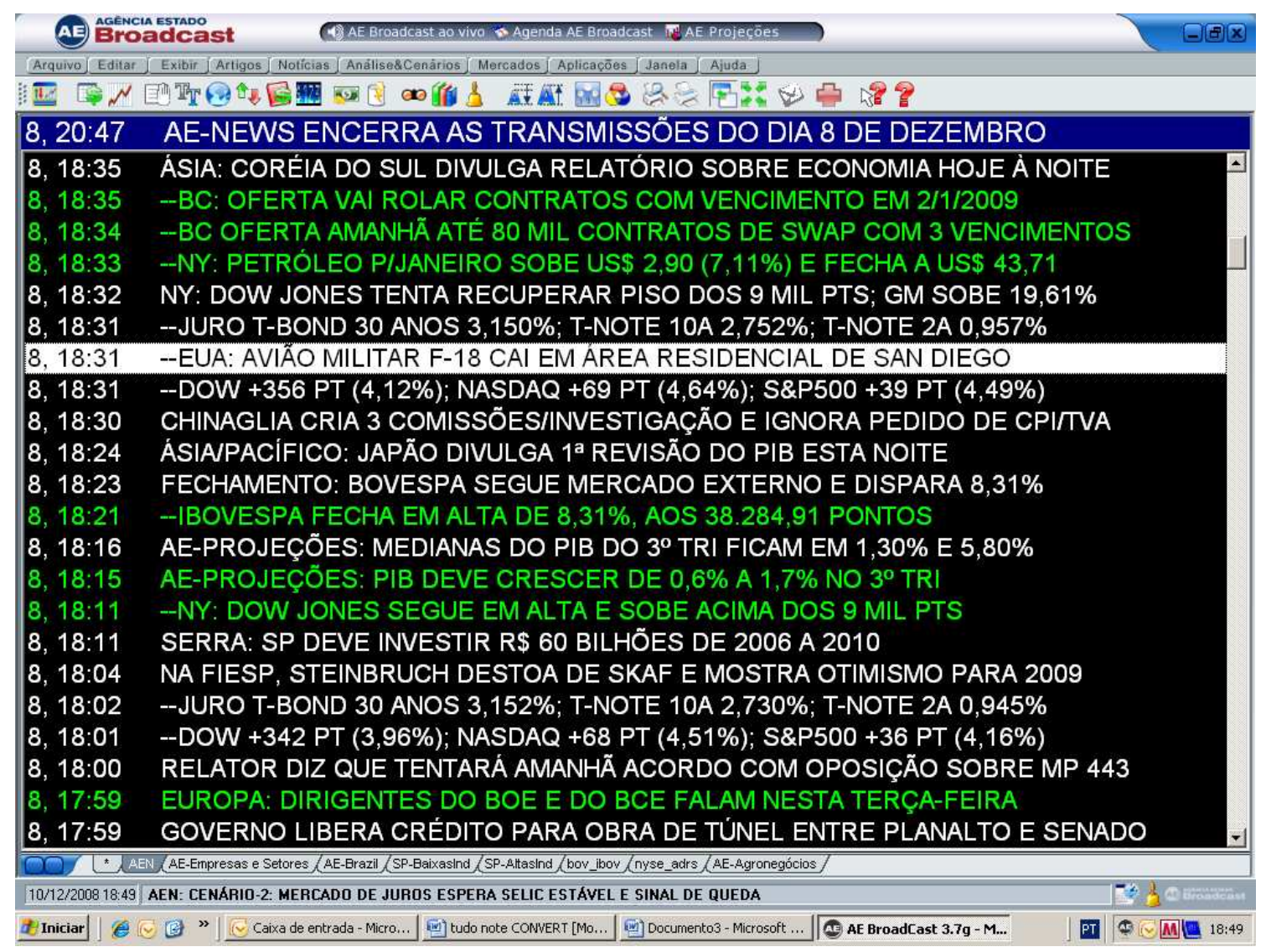

Figura 4. Reprodução de tela do $A E$ News.

Esse noticiário em tempo real feito para e com fontes do mercado financeiro, entretanto, tem impacto fatal sobre jornais, rádios e TVs. Silva (2002), que realizou importante trabalho avaliando a relação entre o jornalismo em tempo real financeiro e os demais veículos de comunicação, concluiu que a Broadcast tem enorme influencia sobre o noticiário econômico nacional.

Apesar de ser um informativo para assinantes pagantes, seu impacto na imprensa brasileira se dá de quatro maneiras: 
a) A equipe de jornalistas da Agência Estado é formada por profissionais especializados em economia e finanças. As matérias desses jornalistas são disponibilizadas às redações dos demais veículos do Grupo Estado - jornais o Estado de S.Paulo e Jornal da Tarde, além da Rádio Eldorado e do portal estadão.com.br. Todos veiculam essas informações;

b) A Agência Estado, proprietária da Broadcast, é a maior agência de notícias do Brasil. Distribui notícias para dezenas de jornais, rádios e TVs em todo o território nacional por meio do produto AE Mídia, que tem cerca de 200 assinantes. O noticiário econômico distribuído pela Agência Estado é, prioritariamente, aquele produzido pela sua equipe de jornalistas, com forte viés financeiro, além de algum material específico do Estadão;

c) O site estadão.com.br, que utiliza matérias veiculadas na Broadcast, é amplamente consultado pelos concorrentes e indiretamente acaba por pautar os noticiários que não assinam o AE Mídia. Em estudo de caso, Silva (2002:49) mostrou que o enquadramento dado a determinados fatos pela Broadcast - como os acordos entre Brasil e FMI e a votação do destaque à Proposta de Emenda à Constituição, que deu isenção da CPMF (imposto Contribuição Provisória sobre Movimentação Financeira) às operações em Bolsa - é o mesmo usado pelos jornais, com a mesma ênfase a termos técnicos e com a visão que interessa ao mercado financeiro;

d) O material produzido pela equipe da Agência Estado é com frequência publicado no Estado. E mesmo que o jornal envie equipe para cobrir evento ao qual a Agência 
Estado também manda, os editores do maior jornal do grupo acompanham a Broadcast durante todo o dia. Com base no que leem, definem como será a cobertura ou o rumo da matéria a ser publicada no dia seguinte no impresso. Além disso, da reunião de pauta do Estadão também participa um profissional da Agência Estado, que conta tudo o que será coberto pela equipe quais as matérias especiais do dia. Os agentes do mercado financeiro, cientes da repercussão da Broadcast para além das fronteiras da Agência Estado, buscam se legitimar como fonte nesse informativo, abrindo portas para aparecer no portal estadão.com.br, no Estadão, na Rádio Eldorado e em outros veículos de imprensa.

O noticiário em tempo real dá ênfase ao factual, reflete um jornalismo relatorial e favorece a visão técnica sobre outras abordagens. O mercado financeiro sempre se sentiu parceiro da Broadcast, tanto que é comum operadores e analistas ligarem sugerindo pautas, reclamando de alguma informação ou oferecendo dados que mostrem que determinada abordagem estaria incorreta (SILVA, 2002:37).

O economista Alexandre Schwartsman, por exemplo, está entre os que mais aparecem no noticiário atualmente. Atende a mais de dez pedidos de entrevistas por mês, trabalhou nas mais importantes instituições financeiras do País, foi um dos diretores do Banco Central na gestão Henrique Meirelles (governo Luiz Inácio Lula da Silva) e é economista sênior para a América Latina do Santander no Brasil, para onde foi depois que a instituição espanhola comprou o holandês ABN Amro, onde Schwartsman trabalhava. O economista contou que começou a ter uma exposição mais frequente na imprensa por meio da Agência Estado, mais precisamente com a jornalista Andreia Lago, editora do AE Mercado, um produto de 
análise que é vendido dentro da Broadcast. "Eu li alguma coisa, escrevi para ela contestando uma informação, aí comecei a aparecer um pouco mais...primeiro na Agência Estado,depois Estadão e Folha... , na segunda metade dos anos 1990” (2007 informação pessoal $)^{49}$.

\subsubsection{CREDIBILIDADE E DEFINIÇÃO DA AGENDA}

A Broadcast construiu tamanha credibilidade junto ao mercado que desfruta, há alguns anos, do status de instituição. É o espaço onde dialogam diariamente governo e mercado financeiro. O mercado, de um lado, percebeu esse noticiário como espaço de influência no governo. E o governo, que a princípio se negava a dialogar nesse espaço, descobriu que não poderia ficar mudo em tal esfera. Começou, então, a utilizá-lo quando precisava "acalmar" os investidores e operadores do mercado financeiro, informar sobre decisões e até para saber da receptividade de suas políticas. O governo antes reagia num ciclo de 24 horas que é o prazo de publicação dos jornais. Mas com o mercado financeiro informatizado, a necessidade de respostas tornou-se muito mais rápida. Até políticos acompanham hoje a Broadcast (SILVA, 2002).

A especialização dos jornalistas e o reduzido nível de erros do noticiário em tempo real ajudaram a construir e consolidar a credibilidade que o AE News/Broadcast desfruta junto ao mercado e a outros veículos de comunicação, dentro de uma visão que privilegia fontes mais técnicas do que políticas. O MST (Movimento dos Sem-Terra), por exemplo, só

\footnotetext{
${ }^{49}$ Informação fornecida por Schwartsman em São Paulo, em entrevista à autora em 2007.
} 
apareceria em um informativo desse tipo se seus atos viessem a impactar alguma decisão de investimento.

Em tese, enquanto as agências em tempo real deveriam cumprir seu papel de intermediar o diálogo governo/mercado financeiro, os jornais gerais deveriam atender a um público nãoespecializado. Mas com a influência do jornalismo em tempo real, as matérias dos jornais ganharam características mais descritivas e relatoriais, enquanto as fontes tornaram-se cada vez mais restritas ao governo, a ex-autoridades e a nomes ligados a instituições financeiras. Em consequência, os jornais gerais passaram a preencher parte considerável de suas páginas com um noticiário muitas vezes sem sentido para o leitor comum, espelhando uma realidade econômica distante do cotidiano da grande maioria das pessoas.

Um exemplo é a Focus, pesquisa semanal que o Banco Central realiza junto a 50 instituições financeiras com o intuito de saber o sentimento delas em relação à economia brasileira. O BC pergunta aos bancos quais suas projeções (numéricas) para uma séria de fundamentos econômicos para os meses à frente: PIB, produção industrial, balança comercial, investimento direto estrangeiro, transações correntes, contas do governo etc. Além desses dados, os economistas do mercado também informam à autoridade monetária em quanto eles acham (e querem) que estará a taxa de juros básica da economia, a Selic, e a cotação do dólar no final de cada mês e no ano. A Broadcast divulga a Focus assim que é liberada pelo Banco Central, às 9 horas das segundas-feiras. O resultado da pesquisa é transformado em matéria na Broadcast, é distribuído pelo AE Mídia, sai nos sites e vai se transformar em abre-de-página nos jornais impressos no dia seguinte. É a partir de matérias desse tipo que a corporação dos economistas dita os rumos da política do Banco Central. 
Segundo Lacerda, quando o Copom (Comitê de Política Monetária que decide sobre a Selic) segue a expectativa do mercado, a imprensa dá a entender que o Banco Central ouviu os anseios dos economistas que sabem o que é melhor para o País. "Mas na verdade, são os economistas que pautam o Copom, porque eles dizem o que esperam que a autoridade monetária faça" (2006 informação pessoal $)^{50}$. Isso acontece, em primeiro lugar, porque o governo é refém do mercado, com o qual tem uma dívida estimada em um trilhão de reais, e também porque o mercado é formador de opinião. "Ora, o Banco Central quer estar bem com o formador de opinião e cede à pressão do mercado financeiro" (Ibid., 2006).

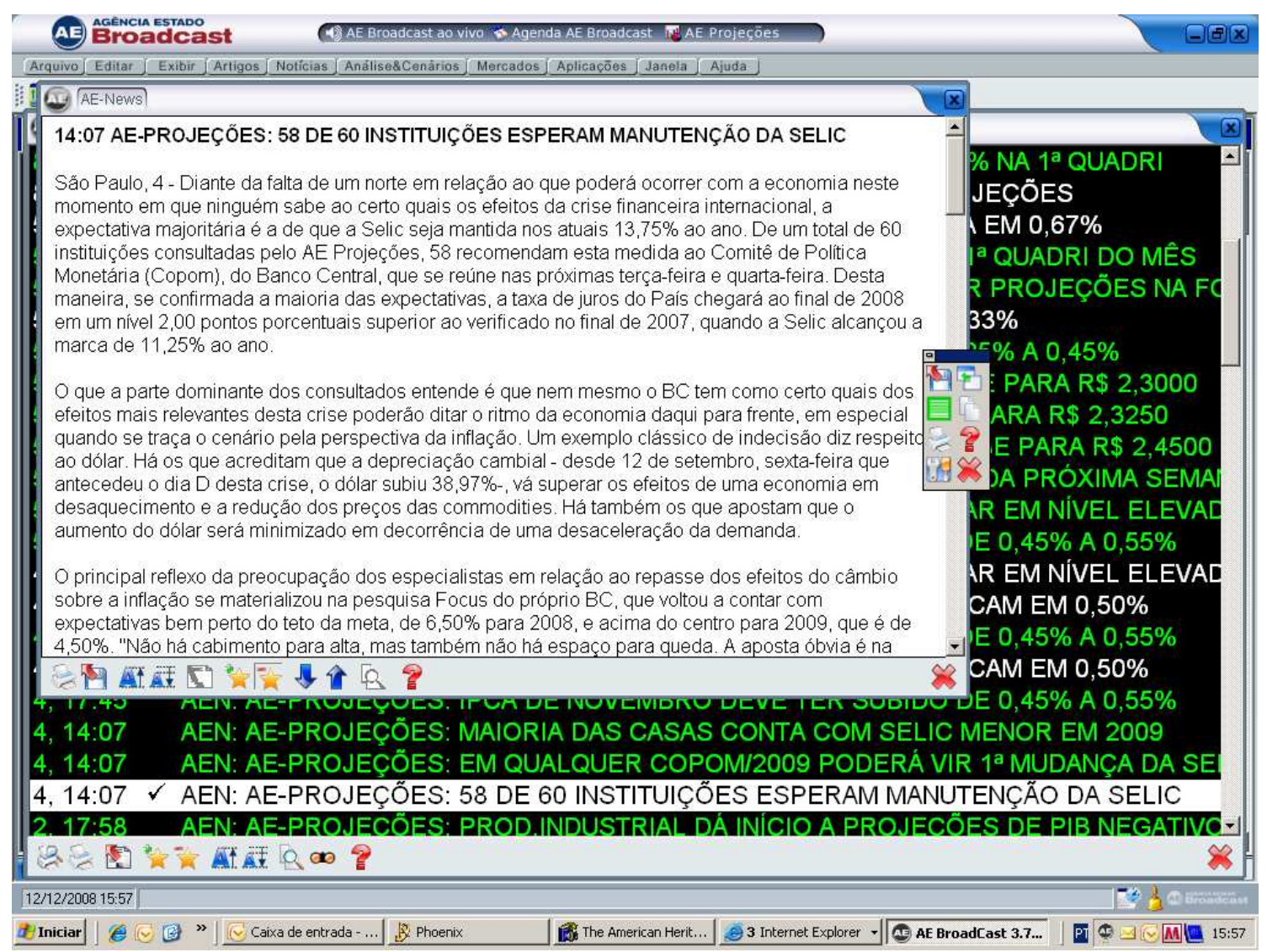

Figura 5. Reprodução pesquisa AE Projeções sobre Selic na tela do AE News.

${ }^{50}$ Informação fornecida por Lacerda em São Paulo, em entrevista à autora em 2006. 


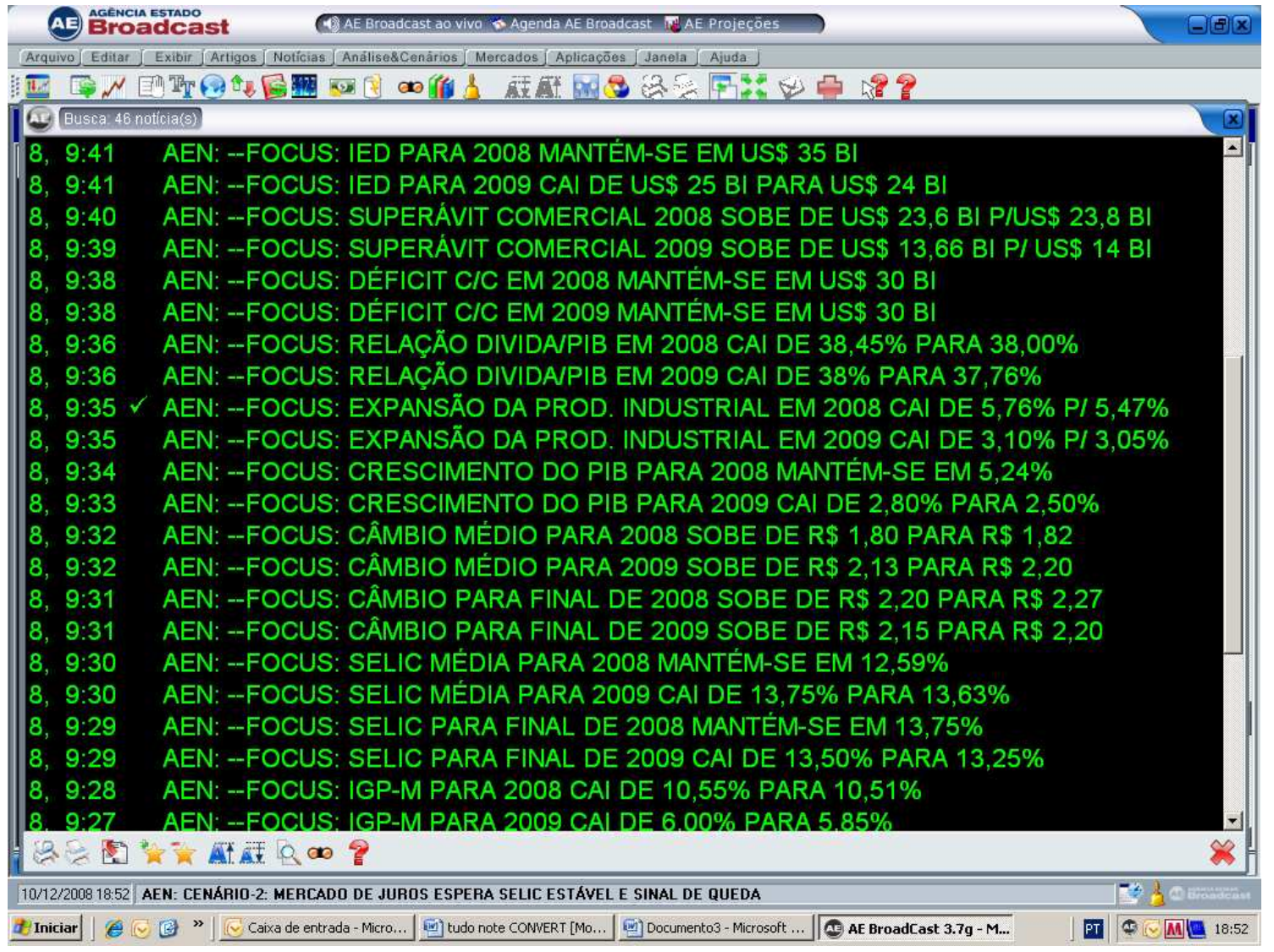

Figura 6. Reprodução de pesquisa Focus do Banco Central na tela do AE News. 


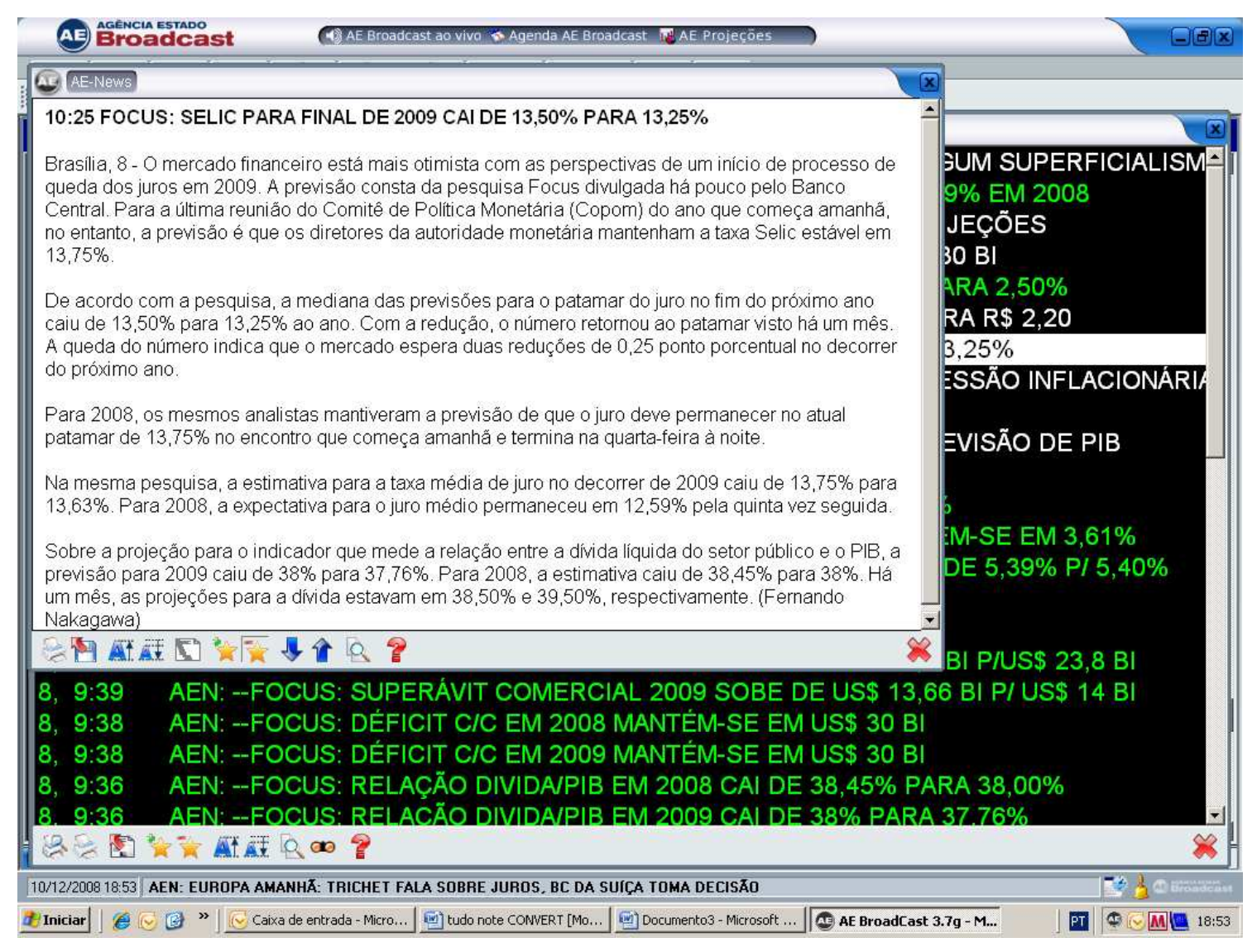

Figura 7. Reprodução de texto de repórter sobre a pesquisa Focus no AE News. 
PARTE DOIS 



\section{CAPÍTULO 4}

\section{A FINANCEIRIZAÇÃO DO JORNALISMO ECONÔMICO NO BRASIL - 2 \\ PESQUISAS - 1}

Esta segunda parte do trabalho dedica-se às pesquisas. Elas buscam mostrar o nível de financeirização do noticiário econômico brasileiro. Financeirização, para relembrar, é a predominância de discursos, temas e fontes de interesse do mercado financeiro nos jornais.

Seguindo a adoção do receituário de modernização do "Consenso de Washington" e o movimento dos capitais internacionais que ingressavam no País, assuntos como privatizações, rigor fiscal, reformas, títulos do Tesouro, captação, renda fixa, renda variável e câmbio começaram a ganhar espaço no noticiário. Trata-se de um vocabulário muito específico, presente tanto no discurso do governo quanto no das novas fontes financeiras que começavam a surgir na imprensa econômica. Para demonstrar a evolução da financeirização do noticiário, foram realizadas quatro pesquisas. As duas primeiras mostram o perfil do noticiário econômico do período em análise (1989-2002, entre o final do governo José Sarney, passando pelos governos de Fernando Collor de Mello, Itamar Franco e Fernando Henrique Cardoso). As duas seguintes são entrevistas com profissionais ligados ao objeto deste estudo, de economistas a jornalistas, acadêmicos e ex-banqueiros. 
Tomadas em conjunto, as pesquisas buscam demonstrar: a) o surgimento e a consolidação do processo de financeirização do noticiário econômico e b) o uso de um amplo arsenal de estratégias de agentes do mercado financeiro para se aproximar dos jornalistas e se consolidar como porta-vozes do saber econômico. Ao mesmo tempo em que aumentou o peso das assessorias na divulgação de fontes, economistas do mercado foram treinados para falar com os jornalistas, acompanhando a criação e a consolidação dos departamentos de economia, que seriam a face dos bancos junto aos clientes empresariais, mas têm ampla inserção na mídia.

\subsection{PROBLEMÁTICA METODOLÓGICA}

É um desafio encontrar metodologia capaz de mostrar que um discurso é criado, burilado e moldado para convencer que o interesse de poucos é o interesse de todos e que o interesse desses poucos é influir na agenda nacional e ditar como a sociedade deve pensar em termos econômicos. Nenhum banqueiro ou economista de banco admitiria a um jornalista a existência de interesses setoriais ocultos na defesa dos princípios neoliberais-financeiros. Nem mesmo em uma conversa com o gravador desligado. Considerando que a linguagem da economia é regida por três códigos - o discurso racional/científico, o da explicitação de interesses de grupos e o da economia real, que tem a ver com o dia a dia de todos os cidadãos (HARVEY, 1993) - encontrar a metodologia de pesquisa foi ainda mais desafiador. 
A tabulação de dados de conteúdo realizada logo no início do trabalho resultou algo estatístico. As pesquisas quantitativas não foram suficientes para dimensionar a amplitude da financeirização do noticiário econômico, e os números levantados no discurso manifesto dos jornais precisavam ser socialmente interpretados. A opção para se conseguir uma leitura social capaz de dar dinâmica aos dados foi a realização de entrevistas com personagens da financeirização. Optou-se por dois tipos de conversas. Primeiro, foram feitas entrevistas dirigidas com economistas do sistema financeiro que sempre aparecem como fontes. Depois foram realizadas entrevistas abertas com personagens do mercado financeiro, jornalistas, acadêmicos e banqueiros. Esses depoimentos foram fundamentais. Explicaram o porquê dos números, além do processo social e de mediações que resultou no discurso manifesto no noticiário econômico e na escala de ocupação do mercado financeiro no espaço editorial. Os depoimentos acrescentaram componentes subjetivos do processo de financeirização que a análise quantitativa do discurso dos jornais não conseguiu revelar.

É preciso esclarecer dois pontos. O primeiro é que em nenhum momento este trabalho pretendeu verificar o impacto da mensagem no receptor. $\mathrm{O}$ foco foi o emissor, a fonte da matéria jornalística, aquele que dá entrevistas, e sua interferência nos atributos da reportagem. A segunda questão é que o estudo centra-se na dimensão ideológica de ações e palavras, sem ingressar no plano linguístico da análise do discurso, mas investigando as condições operacionais e sociais que o geraram. 


\subsection{PESQUISAS QUANTITATIVAS - ANÁLISE DOCUMENTAL - VERIFICAÇÃO DE FONTES DO NOTICIÁRIO ECONÔMICO}

A primeira pesquisa analisou as fontes de todas as matérias econômicas da amostragem, mostrando a procedência dos entrevistados, conforme categorização explicitada abaixo. $\mathrm{O}$ objetivo foi verificar como evoluiu a presença de agentes do mercado financeiro como fontes para matérias, obtendo assim um primeiro dado sobre a financeirização. Em jornalismo, fontes não são apenas pessoas que podem ser entrevistadas, mas também instituições que produzem estudos ou que têm informações que geram notícias - seria o caso, por exemplo, de um levantamento da Agência da Organização das Nações Unidas para Comércio e Desenvolvimento (Unctad) sobre investimento direto estrangeiro mundial. Para produzir uma matéria com esse estudo, o jornalista não precisa entrevistar ninguém. Ele tem acesso ao trabalho escrito, com sumário executivo e principais conclusões, o que costuma ser considerado suficiente pelos editores para a elaboração de matéria, dispensando entrevistas. Utilizar material institucional como fonte de matérias é muito comum nas redações.

O período proposto de análise, entre 1989 a 2002, corresponde ao início do processo de abertura política e econômica e à consequiente consolidação do neoliberalismo no País, bem como sua influência no noticiário. Para a pesquisa, a amostra escolhida foi formada por dois dos principais jornais gerais do Brasil, O Estado de S.Paulo e Folha de S. Paulo. São dois jornais paulistanos, de penetração nacional, cuja escolha levou em conta o fato de 
ambos terem cadernos de economia. $O$ Globo, embora de circulação nacional, não entrou na pesquisa porque suas informações de economia não são veiculadas em caderno exclusivo.

Para a análise de $O$ Estado, a pesquisa observou as edições do dia 10 de cada mês do primeiro semestre dos anos ímpares 1989, 1991, 1993, 1995, 1997, 1999 e 2001 do caderno de economia. A opção pelo dia 10 de cada mês foi aleatória, mas não a escolha dos semestres. A opção pelo primeiro e não pelo segundo semestre de cada ano foi feita na tentativa de tirar da análise a influência das eleições no noticiário. O mercado financeiro se posiciona claramente a favor de um ou outro candidato, e essa preferência fica ainda mais evidente no período mais próximo às eleições (segundos semestres). Para tentar escapar de eventuais distorções no levantamento, escolheu-se trabalhar com amostras da primeira metade de cada ano.

Cada edição do caderno de economia do Estado tem em média oito páginas de notícias, com quatro matérias em cada uma. Assim, foram avaliadas 32 notícias por edição ou 192 matérias por semestre. Como foram sete semestres, a amostra analisada foi de cerca de 1.340 noticias.

Para análise da Folha, foram observadas as edições do dia 10 de cada mês do primeiro semestre dos anos pares 1990, 1992, 1994, 1996, 1998, 2000 e 2002, complementando os 14 anos de abrangência do trabalho. Cada edição da Folha tem em média seis páginas de notícias, com média de quatro matérias em cada uma. Assim, foram avaliadas 24 notícias 
por edição do caderno, o que significa 144 matérias por semestre, gerando uma amostra de cerca de 1.000 matérias em sete anos.

Não se trata de pesquisa comparativa entre os jornais. A escolha de anos pares para um veículo e ímpares para outro também foi aleatória, buscando-se apenas analisar por amostragem 14 anos de produção jornalística englobando os dois periódicos.

Para o levantamento quantitativo do noticiário, cada matéria foi classificada em uma ficha contendo informações que servem tanto para a pesquisa 1 - VERIFICAÇÃO DE FONTES DO NOTICIÁRIO ECONÔMICO quanto para a pesquisa 2 - VERIFICAÇÃO DE TEMAS, NÚMERO E CATEGORIAS DE FONTES DAS MATÉRIAS-MANCHETES. Foram levantados os seguintes dados:

-Nome do jornal

-Data da publicação

-Número da página

-Título da matéria

-Palavras-chave do título

-Tema da reportagem ${ }^{51}$

-Número de fontes ${ }^{52}$

-Natureza/procedência de fontes, conforme as seguintes categorias:

51 Detalhamento desse item será realizado no tópico 4.3.1.1 COMENTÁRIOS da VERIFICAÇÃO DE TEMAS, NÚMERO E CATEGORIAS DE FONTES DAS MATÉRIAS-MANCHETES.

52 Detalhamento desse item será realizado no tópico 4.3.1.1 COMENTÁRIOS da VERIFICAÇÃO DE TEMAS, NÚMERO E CATEGORIAS DE FONTES DAS MATÉRIAS-MANCHETES. 
a) Governo (presidente da República, ministros de Estado, assessores e quaisquer funcionários de órgãos governamentais das esferas federal, estaduais e municipais);

b) Mercado financeiro/bancos/consultorias (economistas e analistas de bancos, operadores do mercado de capitais, presidentes, diretores e gerentes de bancos, economistas de consultorias, funcionários das bolsas de valores e entidades multilaterais, como Fundo Monetário Internacional, Banco Mundial, Banco Interamericano de Desenvolvimento, Banco de Compensações Internacionais, Instituto de Finanças Internacionais);

c) Empresários (da indústria, do comércio, de serviços e produtores rurais, exceto banqueiros, que entram na categoria acima);

d) Trabalhadores e sindicalistas;

e) Institutos de pesquisa (especificamente os que divulgam índices de inflação, como IBGE, FGV, Fipe e Dieese) $)^{53}$;

f) Outros (parlamentares, tribunais federais e regionais, acadêmicos, instituições multilaterais não-financeiras, como Organização das Nações Unidas, Organização Mundial do Comércio - OMC, associações de inquilinos, de consórcios, advogados e todos os profissionais que não se enquadram nos grupos anteriores).

-Transparência das fontes:

a) Se estão bem identificadas, com nome, cargo e instituição em que trabalham;

b) Se são identificadas apenas pela instituição à qual estão ligadas, sem publicação do nome do entrevistado;

\footnotetext{
${ }^{53}$ IBGE (Instituto Brasileiro de Geografia e Estatística); FGV (Fundação Getúlio Vargas), Fipe (Fundação Instituto de Pesquisas Econômicas); Dieese (Departamento Intersindical de Estatísticas e Estudos Socioeconômicos).
} 
c) Se é fonte não-identificada, como por exemplo "assessores do Ministério da Fazenda" ou "fontes próximas ao ministro" ou "fontes do mercado financeiro" ou "economistas", o que caracteriza o "off-the-record" parcial;

d) Se a matéria não tem fonte alguma ("off-the-record" total);

e) Se trata-se de identificação enganosa, ou seja, aparece como ex-autoridade, mas no momento da pesquisa representava interesses do setor privado. Exemplo: "o ex-diretor do Banco Central Gustavo Loyola afirmou..." Na verdade, Loyola é dono de uma das maiores consultorias econômicas do Brasil. Mas qualificá-lo como ex-autoridade dá credibilidade à matéria.

Não entraram na pesquisa as colunas assinadas por jornalistas porque, como já foi dito, o trabalho avalia a produção da notícia feita por repórteres. 
Nome: O Estado de S.Paulo

Data da publicação: 10 de março de 1995

Página: 1

Título da matéria: "Duelo entre BC e mercado testa fôlego do real"

Palavras-chave: Banco Central, mercado

Tema da reportagem: Atuação do Banco Central no mercado de câmbio, comprando moeda para segurar a cotação, enquanto os operadores vendem o real

Fontes: Não cita

Transparência: Nenhuma - fontes não identificadas

Figura 8. Exemplo de ficha de levantamento com O Estado de S.Paulo.

Nome: Folha de S.Paulo

Data da publicação: 10 de fevereiro de 1992

Página: 4

Título da matéria: "Cai ritmo de reajustes nos supermercados"

Palavras-chave: Reajuste, supermercados

Tema da reportagem: Inflação nos supermercados

Número de fontes: 1

Fontes: Instituto de Pesquisa Datafolha

Transparência: Fonte é a pesquisa em si, mas não há pesquisador comentando. É transparente

Figura 9. Exemplo de ficha de levantamento com Folha de S.Paulo. 
Nesta primeira pesquisa o foco foi a natureza/procedência das fontes, classificando-as nas categorias descritas acima. Por exemplo: "assessores do Ministério da Fazenda" entraram como fontes do governo; "operadores da Bolsa", foram categorizados como mercado financeiro. Matérias sem fontes não foram contabilizadas nesta etapa, porque o grau de transparência será avaliado em 4.3 PESQUISAS QUANTITATIVAS - ANÁLISE DOCUMENTAL - VERIFICAÇÃO DE TEMAS, NÚMERO E CATEGORIAS DE FONTES DAS MATÉRIAS-MANCHETES.

\subsubsection{TABULAÇÃO DA ANÁLISE DOCUMENTAL - VERIFICAÇÃO DE FONTES DO NOTICIÁRIO ECONÔMICO $^{54}$}

\section{O Estado de S.Paulo}

\section{Primeiro semestre de 1989}

Esse foi um semestre com greves, demissões e algum aumento do consumo, mas os sindicalistas participaram esporadicamente no noticiário como fontes. Em junho, o jornal já aparece com o nome do caderno mudado para Economia \& Negócios.

\footnotetext{
54 Antes do resultado de cada levantamento, há um pequeno texto com os principais acontecimentos econômicos do semestre em análise, para ajudar na contextualização dos dados.
} 


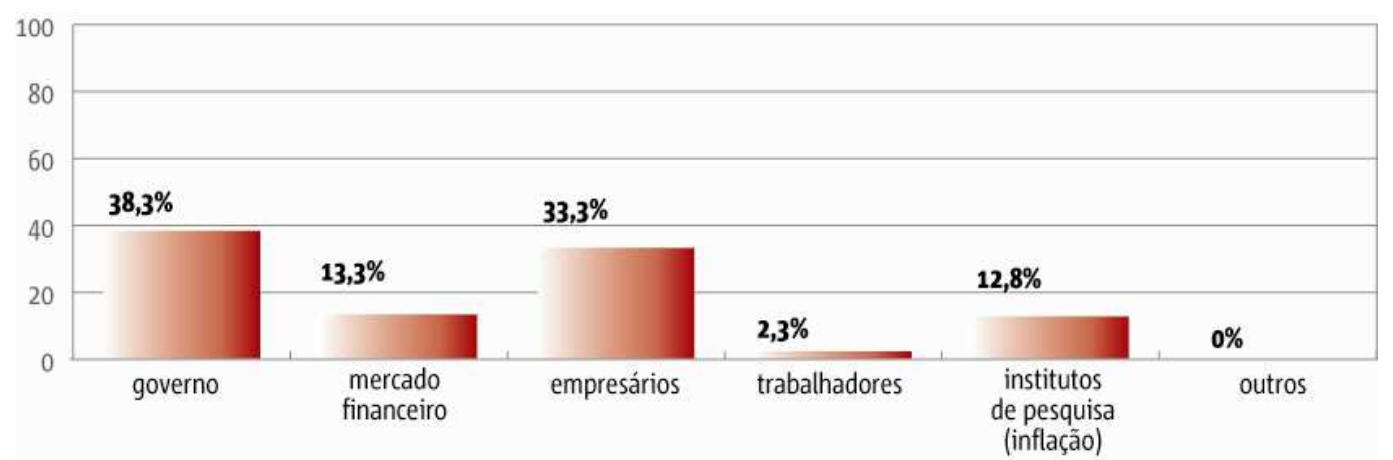

Figura 10. Procedência de fontes, 1o. semestre de 1989.

\section{Primeiro semestre de 1991}

Período marcado por Plano Collor II, Guerra do Golfo, renegociação de dívida externa com o Fundo Monetário Nacional (FMI), substituição de Zélia Cardoso de Mello no Ministério da Fazenda, crise de combustíveis e novos fundos de investimento. Também ocorrem discussões sobre a política salarial em um ambiente de congelamento de preços e inflação em alta. Em março, o governo informa que quer vender oito estatais até junho. O Banco Mundial envia carta à Comissão Diretora de privatizações elogiando o programa, mas faz também uma série de críticas. O ex-ministro da França Edouard Balladur vem ao Brasil com uma espécie de cartilha para ensinar como se faz um programa de privatizações. $\mathrm{O}$ FMI diz que as metas de estabilização econômica são fundamentais para se chegar a um acordo sobre a dívida e para haver acesso ao mercado internacional de capitais. No período, o jornal publicou duas vezes entrevistas com Jeffrey Sachs, da Universiade de Columbia (EUA), pedindo mudanças na economia brasileira, com abertura comercial, fim dos 
subsídios à indústria e privatizações. Sachs foi conselheiro de governos da América Latina, do Leste Europeu, da extinta União Soviética, Ásia e África

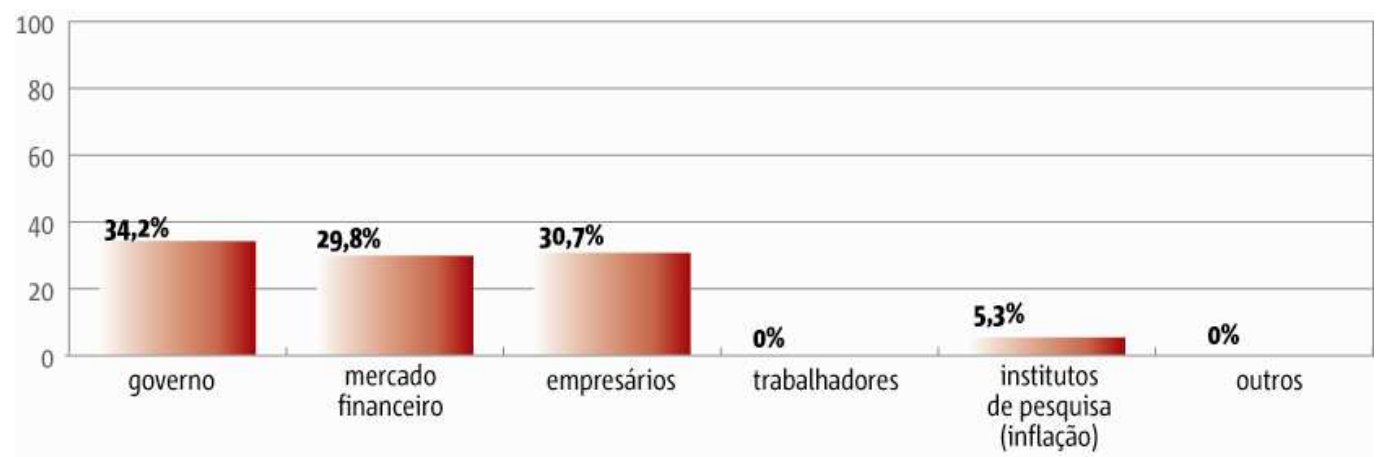

Figura 11. Procedência de fontes, 10. semestre de 1991.

\section{Primeiro semestre de 1993}

Já com Itamar Franco na Presidência, os temas centrais do noticiário continuam a ser inflação, fundos de investimentos e as primeiras pinceladas da montagem sigilosa do então chamado "Plano FHC", que viria a ser o Plano Real. Começam a aparecer mais sistematicamente notícias sobre comportamento das bolsas de valores no Brasil e no mundo, além das primeiras discussões sobre privatizações e ações do Banco Central no mercado de câmbio. 


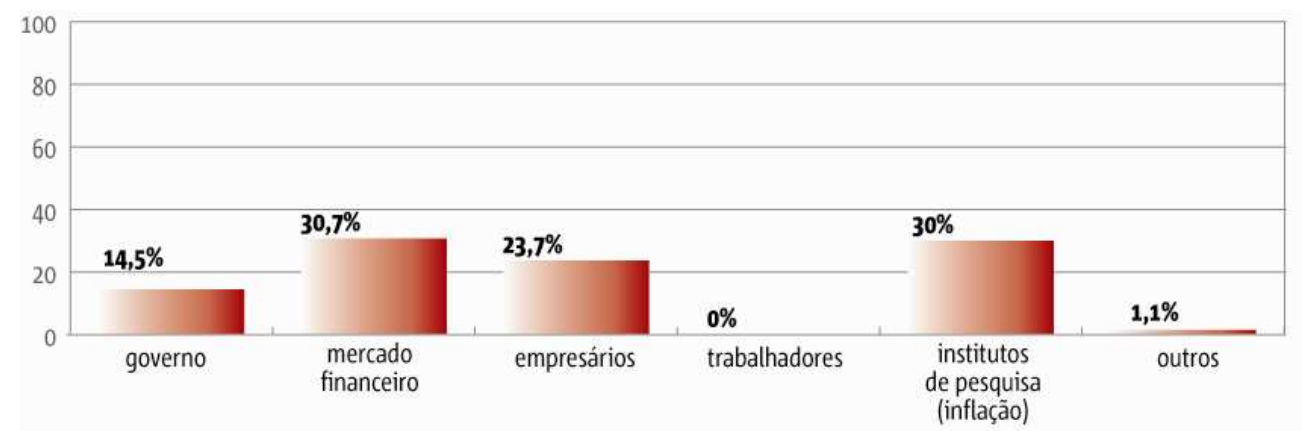

Figura 12. Procedência de fontes, 1o. semestre de 1993.

\section{Primeiro semestre de 1995}

Repercussões da crise especulativa no México nos mercados de câmbio e de capitais, problemas econômicos na Argentina, privatizações, inflação, negociação salarial e reforma da previdência dominam o noticiário. Já lançado o Plano Real, as ações do Banco Central no mercado de câmbio e o comportamento das bolsas passam a estar diariamente no noticiário com destaque. Também estreia coluna de análise diária do mercado financeiro pela jornalista Angela Bittencourt. 


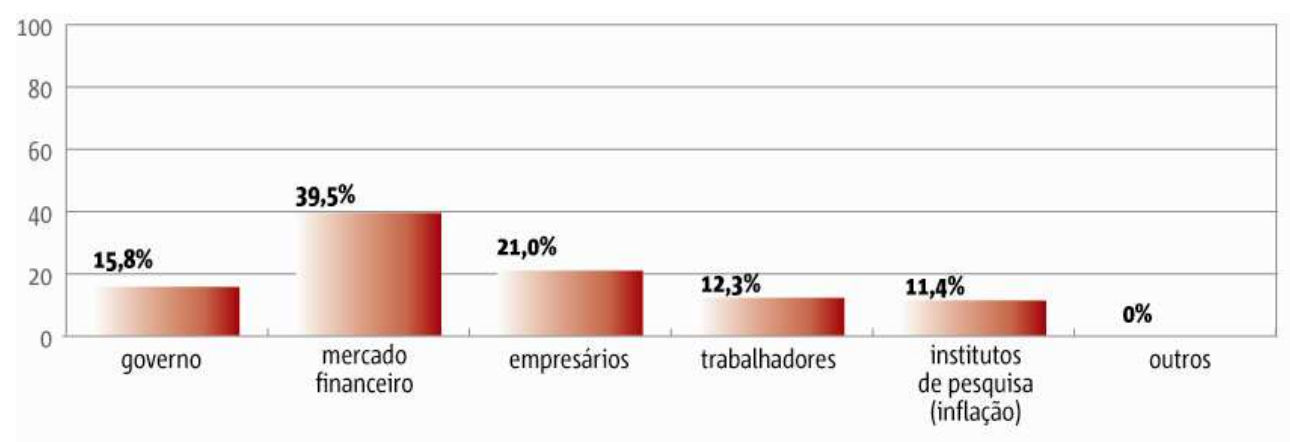

Figura 13. Procedência de fontes, 1o. semestre de 1995.

\section{Primeiro semestre de 1997}

Nesse período que antecedeu à crise da Ásia, os temas centrais do noticiário econômico são privatizações, sobretudo Vale e Telebrás, além medidas para estabilização da economia, aumento dos investimentos e emissão de títulos públicos para obtenção das necessidades de financiamento do Estado.

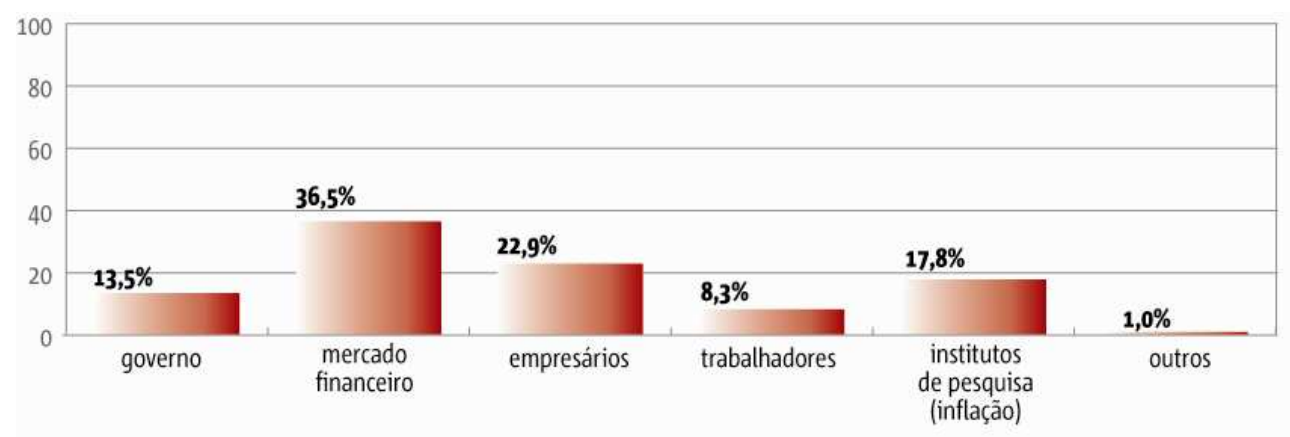

Figura 14. Procedência de fontes, 1o. semestre de 1997. 


\section{Primeiro semestre de 1999}

É o semestre do fim do sistema de bandas cambiais e da flutuação da moeda, com repercussões nos mercados de juros, bolsa e câmbio. Muito material escrito pelo $A E$ News, noticiário para o mercado financeiro da Agência Estado. Aparecem ainda matérias sobre contenciosos do Brasil na OMC e de defesa do corte de gastos públicos.

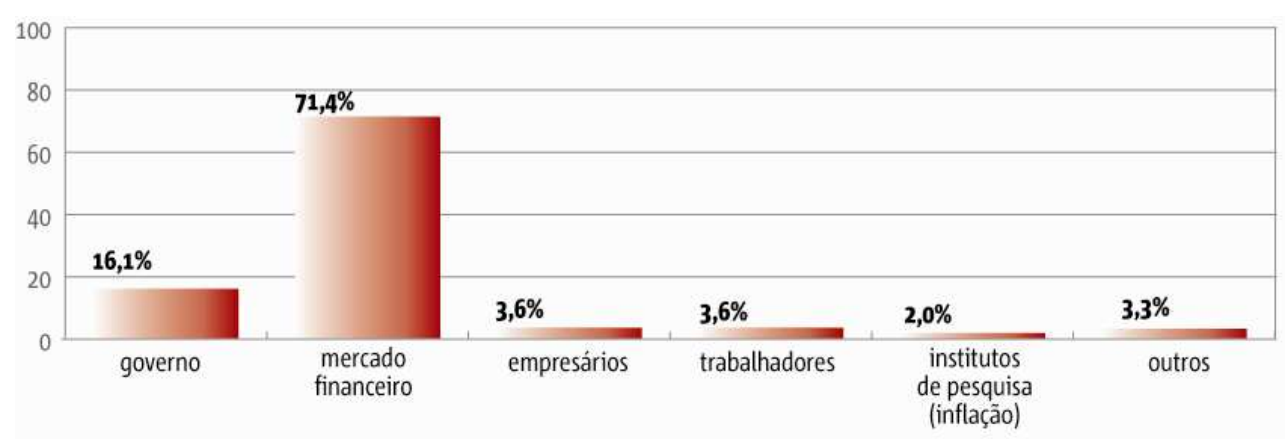

Figura 15. Procedência de fontes, 1o. semestre de 1999.

Primeiro semestre de 2001

Ainda há muitas matérias de temas do mercado financeiro, como empréstimos do governo por meio de oferta de títulos do Tesouro, contenciosos do Brasil na Organização Mundial do Comércio (OMC), contas públicas, mas com avanço forte dos temas de eletricidade por conta do racionamento ao qual todo o país foi submetido (apagão). Ao mesmo tempo, estoura a bolha das empresas de internet nos Estados Unidos, as apelidadas de pontocom. Usa-se bolha como uma figura de linguagem para um processo de crescimento 
inconsistente, sem produção real, vazio, que vai se ampliando até estourar. As bolsas de valores despencam no mundo todo.

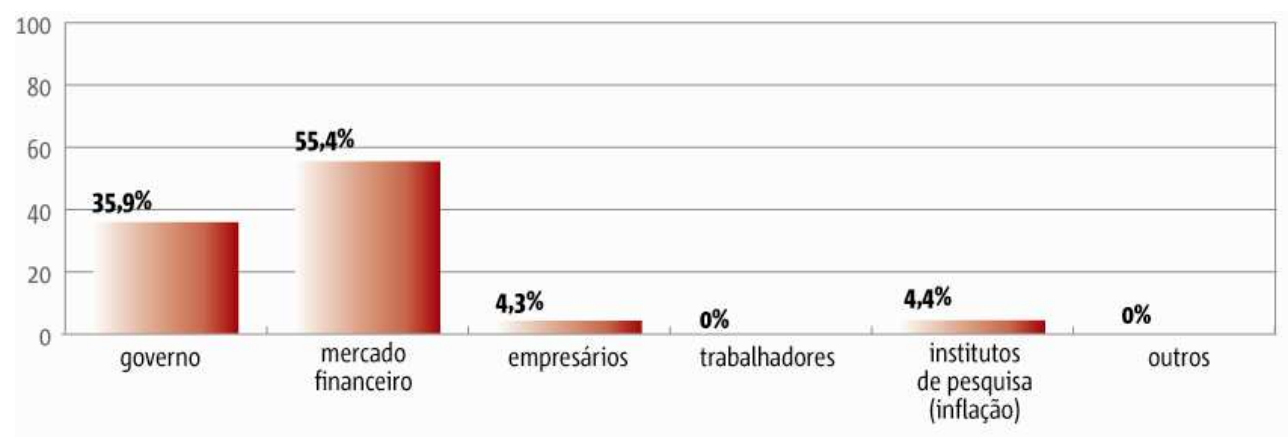

Figura 16. Procedência de fontes, 10. semestre de 2001.

\section{Folha de S.Paulo}

\section{Primeiro semestre de 1990}

O Plano Collor, o confisco da poupança, a inflação e as aplicações financeiras como proteção contra a alta dos preços, além de negociações salariais são o destaque no período. A Folha já adota o chapéu "mercado financeiro" acima das matérias para identificar o tema a que se refere o título da reportagem. O jornal também publica matéria diária de análise do comportamento do mercado financeiro no dia anterior. É assinada apenas com as iniciais do jornalista que a produz, publicada em itálico e nunca cita fontes. 


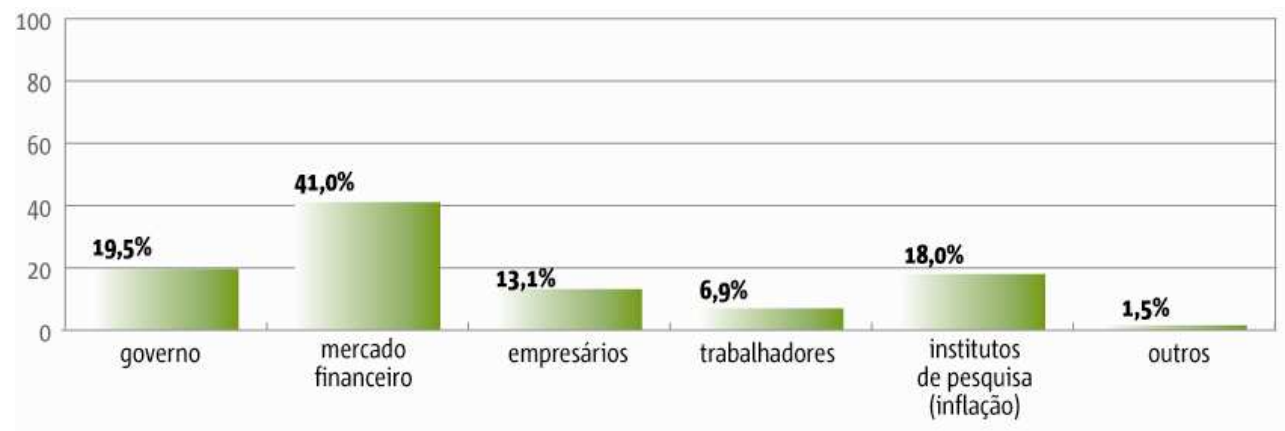

Figura 17. Procedência de fontes, 1o. semestre de 1990.

Primeiro semestre de 1992

Noticiário dominado por inflação, comportamento do mercado financeiro, aumento dos juros, investimentos, greves e demissões, além do chamado ajuste fiscal, que é o corte nas despesas do governo. Com reforma gráfica, Folha lança o caderno Dinheiro.

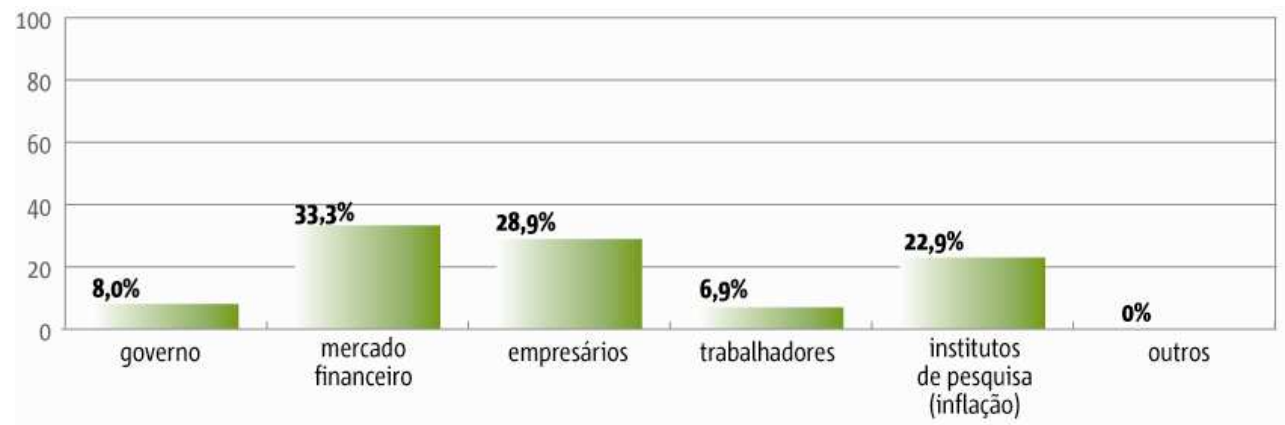

Figura 18. Procedência de fontes, 1o. semestre de 1992. 


\section{Primeiro semestre de 1994}

Inflação continua em alta no noticiário. Em fevereiro, a Folha passa a oferecer o Folha Informações, serviço com as cotações do dólar por CR \$ 540 o minuto. A manchete do jornal de 10 de fevereiro é "Real chega em julho com deflator", com repercussões do plano anti-inflação do então ministro Fernando Henrique Cardoso nos investimentos. Em maio o jornal publica caderno especial de seis páginas sobre o Plano FHC-Real, só com fontes oficiais. O jornal usa o chapéu "Indisciplina" em matéria sobre os gastos das estatais que estouram o orçamento, introduzindo um sentido negativo para gastos públicos. Fernando Henrique deixa a Fazenda para se candidatar ao Planalto. Seu sucessor, Rubens Ricupero, promove uma nova onda de corte nas tarifas de importação, ampliando a abertura do Brasil ao Exterior.

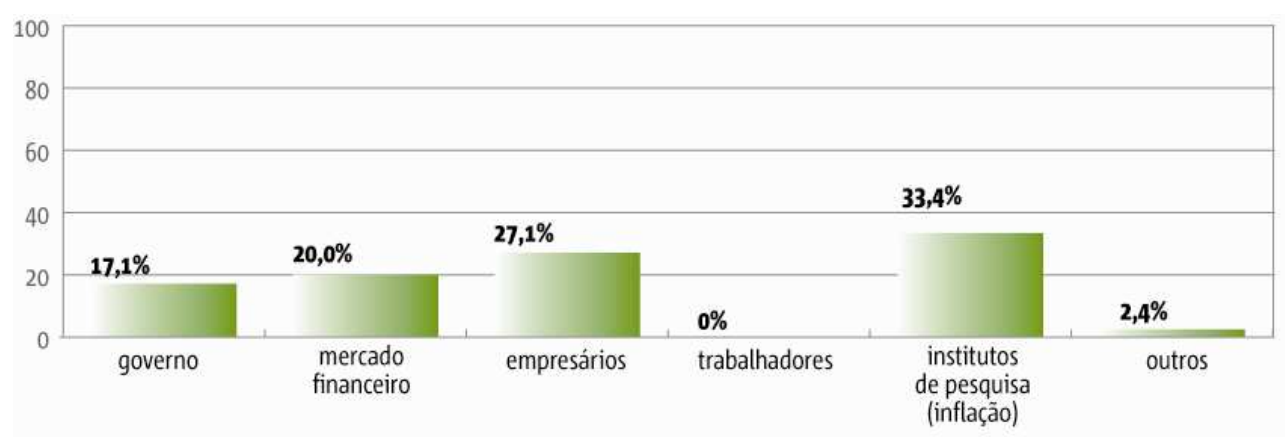

Figura 19. Procedência de fontes, 1o. semestre de 1994. 


\section{Primeiro semestre de 1996}

Neste período, são retomadas mais intensamente propostas do governo para a reforma do sistema previdenciário. Noticiário é dominado por temas relacionados a contas públicas e necessidade de cortes nos gastos do governo. Nos Estados Unidos, o Federal Reserve (equivalente ao Banco Central daquele país) eleva as taxas básicas de juros. O mercado acionário mundial despenca. Aqui, bancos são suspeitos de alterar balanços; dentro de um processo de fraudes bancárias, cogita-se a abertura de uma Comissão Parlamentar de Inquérito (CPI) para investigá-los. $\mathrm{O}$ setor se mobiliza contra a ação, dizendo que prejudicaria o País em várias frentes, incluindo captação de recursos (empréstimos) internos e externos. O noticiário mostra que Fernando Henrique se coloca ao lado dos bancos, temendo repercussões na imagem do País. Estrangeiros criticam a suposta lentidão das reformas e colocam-nas como a condição para o País crescer.

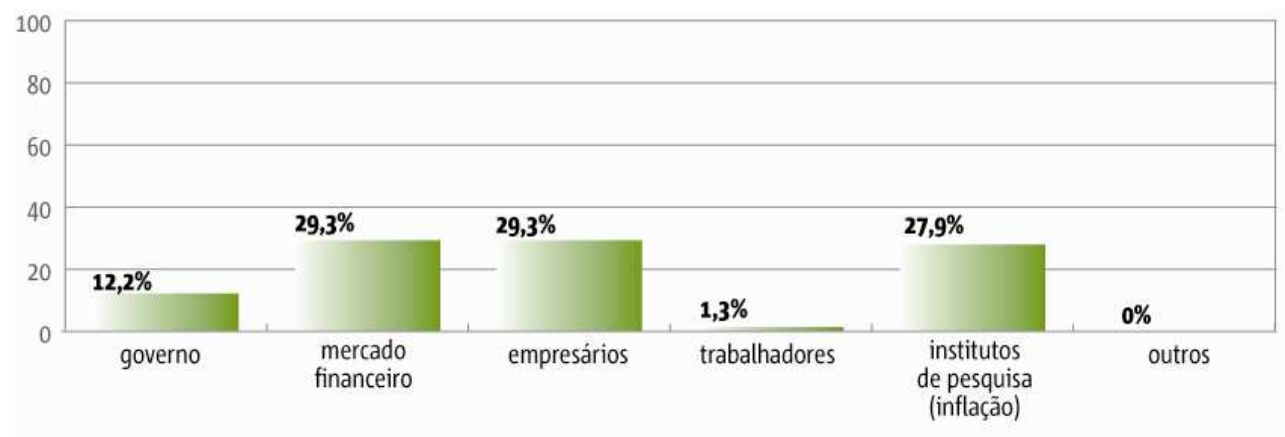

Figura 20. Procedência de fontes, 1o. semestre de 1996. 


\section{Primeiro semestre de 1998}

Estoura pela Indonésia a crise da Ásia com fuga em massa de capitais financeiros dos países a caminho da industrialização, então chamados de Tigres Asiáticos. Dependente do capital especulativo estrangeiro, o Brasil escorrega na mesma esteira. Aqui, o noticiário é dominado por temas de socorro financeiro, juros, câmbio e bolsas de valores. Os juros sobem para conter a fuga de capitais, a moeda local se desvaloriza e cresce o espaço para as opiniões de operadores e analistas do mercado financeiro no noticiário. Matérias sobre o andamento das reformas também continuam constantes. O governo revela que os recursos das privatizações vão abater dívida pública.

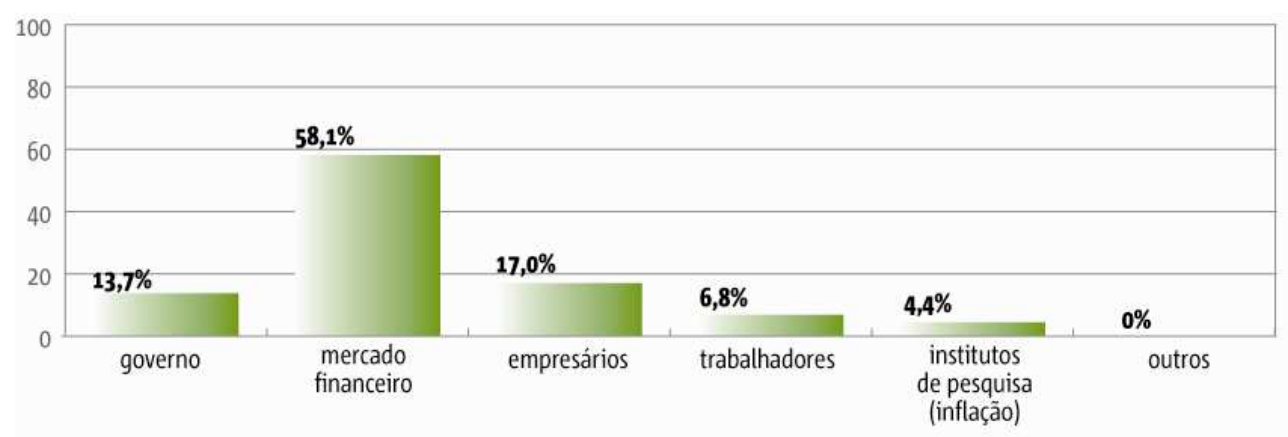

Figura 21. Procedência de fontes, 1o. semestre de 1998.

Primeiro semestre de 2000

O noticiário continua a repercutir as crises econômicas. Mas analistas dizem que o mercado de ações aqui voltou a ser atraente, porque as ações ficaram muito baratas. Estoura o 
escândalo dos bancos Marka e Fonte Cindam, que com suposta conivência do Banco Central ganharam dinheiro em operações em prejuízo aos cofres públicos.

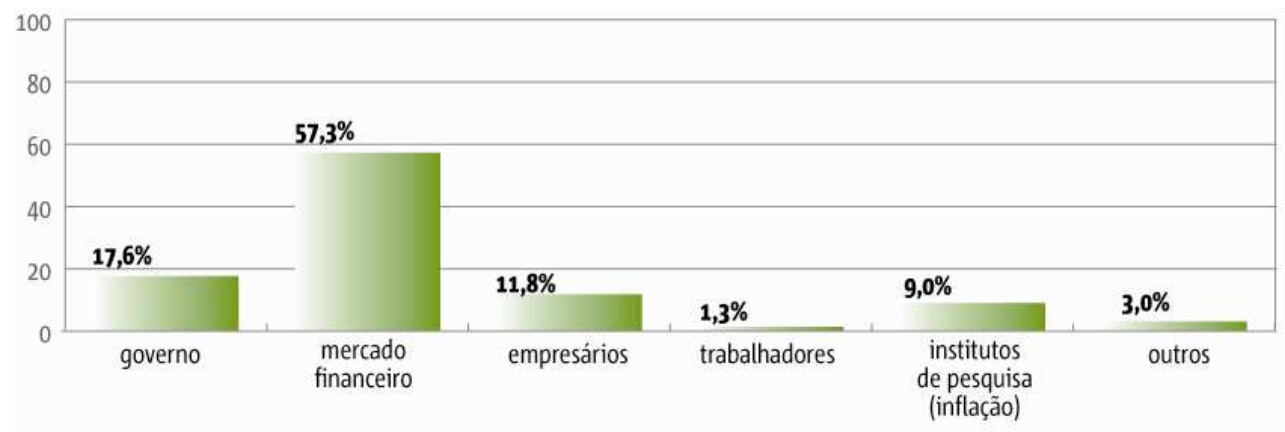

Figura 22. Procedência de fontes, 10. semestre de 2000.

Primeiro semestre de 2002

Os meses que antecederam à eleição de Luiz Inácio Lula da Silva, do PT, à Presidência da República registram um forte movimento especulativo no mercado de capitais. Havia temores de que, se eleito, Lula alteraria os rumos da política de estabilização econômica. O País vive uma espécie de crise cambial por conta de especuladores, que usam a incerteza política para especular com o real, levando o dólar a valer quase quatro reais. Esse foi o tema que prevaleceu no noticiário. O FMI vem a público dizer que apesar das reformas, a América Latina não cresceu, porque as mudanças não foram feitas de acordo com o receituário, e pede que o Brasil gaste menos e exporte mais. 


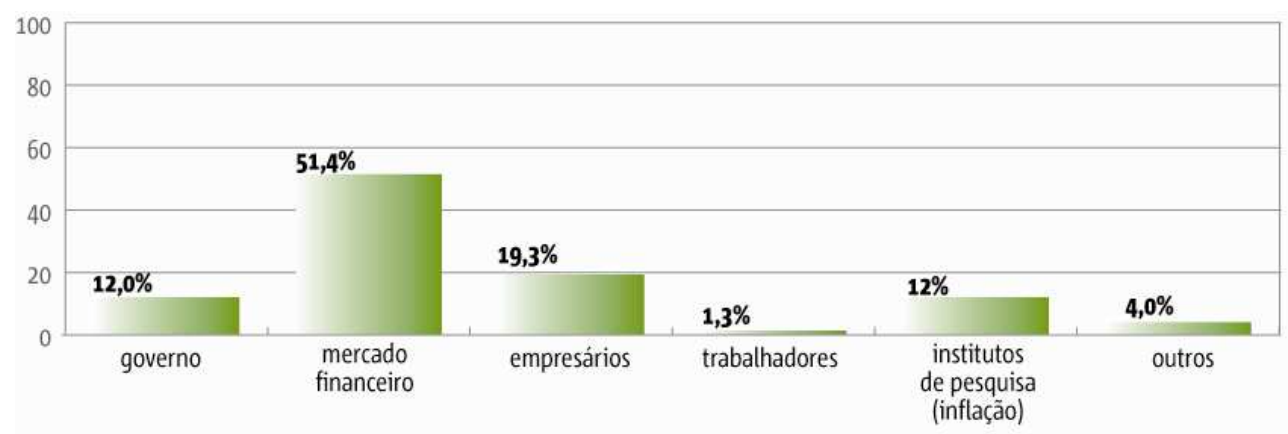

Figura 23. Procedência de fontes, 1o. semestre de 2002.

\subsubsection{COMENTÁRIOS}

A análise da amostra de 14 anos mostrou que as fontes do mercado financeiro apareceram mais do que quaisquer outras no noticiário econômico. A afirmação é verdadeira tanto para o Estado quanto para a Folha, embora o objetivo do trabalho não tenha sido comparar o comportamento entre os dois jornais.

Em 1989, as fontes do governo e os empresários ainda prevaleceram sobre as outras. Mas já em 1990 a predominância de fontes do mercado no noticiário começou de forma bastante visível. Foi a partir daquele ano que os economistas do mercado financeiro começaram a ser ouvidos para explicar os instrumentos que os bancos ofereciam para proteger o dinheiro dos brasileiros da corrosão inflacionária. Em meio à crise do confisco da poupança promovido pelo governo Collor, a Folha passou a trazer análise diária do comportamento dos mercados de ações, câmbio e juros. 
A pesquisa mostrou que em 1992 houve uma importante mudança no noticiário. A partir daquele ano os profissionais do mercado financeiro deixaram de aparecer exclusivamente em matérias sobre investimentos e passaram a repercutir ações do governo, sobretudo as ligadas às reformas recomendadas pelo "Consenso de Washington", conquistando assim um espaço na opinião de temas de política econômica que até hoje não foi perdido.

De 1990 a 2002, segundo a pesquisa, única exceção ao predomínio das fontes do mercado financeiro sobre outras categorias foi verificada em 1994, no governo Itamar Franco, quando os institutos de pesquisa de preços prevaleceram sobre quaisquer outras fontes, por conta de mais um período de descontrole de preços.

\subsection{PESQUISAS QUANTITATIVAS - ANÁLISE DOCUMENTAL - VERIFICAÇÃO DE TEMAS, NÚMERO E CATEGORIAS DE FONTES DAS MATÉRIAS-MANCHETES}

Diferente da primeira pesquisa que qualificou e quantificou as fontes de todas as matérias da amostra, esta segunda pesquisa focou apenas nas matérias que os editores consideram as mais importantes de cada página, as manchetes, também chamadas abres-de-páginas. O objetivo foi aprofundar e complementar a investigação anterior, porque matérias que estão no alto das páginas têm elementos diferenciadores em relação ao noticiário total, sugerindo sentidos de leitura para o restante da página. Por princípio, o que está no alto é o que o editor considera que seu leitor deva e queira saber. 
A pesquisa procurou identificar:

-Assunto das matérias abres-de-páginas. $\mathrm{O}$ intuito foi mapear que temas predominaram no noticiário, e se eles estavam ou não relacionados a questões do neoliberalismo financeiro. Por semestre, foram identificados os cinco assuntos de maior prevalência no noticiário. Quando o percentual de presença se repetiu para dois ou mais assuntos, todos os assuntos com o mesmo número de aparições foram analisados - quer dizer, houve períodos em que mais de cinco temas apareceram na pesquisa.

-Procedência/categoria: governo, empresários, mercado financeiro, trabalhadores, institutos de pesquisas e outros, conforme já descrito no item 4.2 PESQUISAS QUANTITATIVAS ANÁLISE DOCUMENTAL - VERIFICAÇÃO DE FONTES DO NOTICIÁRIO ECONÔMICO. Quando a fonte é descrita apenas como "fontes" ou "assessores", ela é qualificada como não-identificada (não-id).

-Número de fontes: uma, duas, três ou mais, sem fontes. Em teoria, quanto mais fontes são ouvidas em uma matéria, maior pluralidade de pensamentos ela exprime, com críticas favoráveis e desfavoráveis de diferentes grupos ideológicos sobre o tema em questão. Na prática pode acontecer de uma reportagem trazer mais de uma fonte, porém ou da mesma procedência ou do mesmo grupo ideológico. Feito esse aparte, a análise do número de fontes fornece uma visão sobre se houve ou não decisão editorial de promover um debate de ideias, ouvindo os vários interesses afetados pelas notícias. Deparamo-nos com diversas matérias sem fontes, as apurações "off-the-record". O jornalista escreve, mas não fornece qualquer indício de quem é a fonte de informação. Nesse caso, a pluralidade é considerada zero. 
A análise desses dados em conjunto fornece um panorama sobre o grau de transparência e de pluralidade do noticiário. Em tese, quanto mais transparentes as matérias, de maior credibilidade elas desfrutam e menos interesses elas ocultam.

Para a análise do noticiário, foi utilizada a mesma pesquisa nos jornais mostrada em 4.2, porém com foco apenas nas matérias do alto de cada página. Em O Estado de S.Paulo foram escolhidas as matérias-manchetes das páginas do caderno de economia das edições do dia 10 de cada mês do primeiro semestre dos anos ímpares 1989, 1991, 1993, 1995, 1997, 1999 e 2001. Os critérios de definição já foram descritos em 4.2. Cada edição tem em média oito páginas, o que significa que nesta pesquisa foram avaliadas em média oito notícias por edição, gerando uma amostra ao redor de 330 notícias.

Para análise da Folha de S.Paulo, foram observadas as edições do dia 10 de cada mês do primeiro semestre dos anos pares 1990, 1992, 1994, 1996, 1998, 2000 e 2002. Como cada edição tem em média seis páginas de notícias, foram avaliadas cerca de 250 notícias.

\subsubsection{TABULAÇÃO DA ANÁLISE DOCUMENTAL - VERIFICAÇÃO DE TEMAS, NÚMERO E CATEGORIAS DE FONTES DAS MATÉRIAS-MANCHETES}

Cada semestre desta pesquisa teve no mínimo onze análises. Na abertura de cada semestre,

o primeiro quadro a aparecer é o que mostra os temas de maior predominância no 
noticiário. Em seguida, cada tema é destrinchado em dois outros quadros, o primeiro com a procedência de fontes por categoria e o segundo com o número de fontes do material analisado - com o objetivo de revelar pluralidade e transparência.

\section{O ESTADO DE S.PAULO}

a) Principais temas da amostra do noticiário do primeiro semestre de 1989

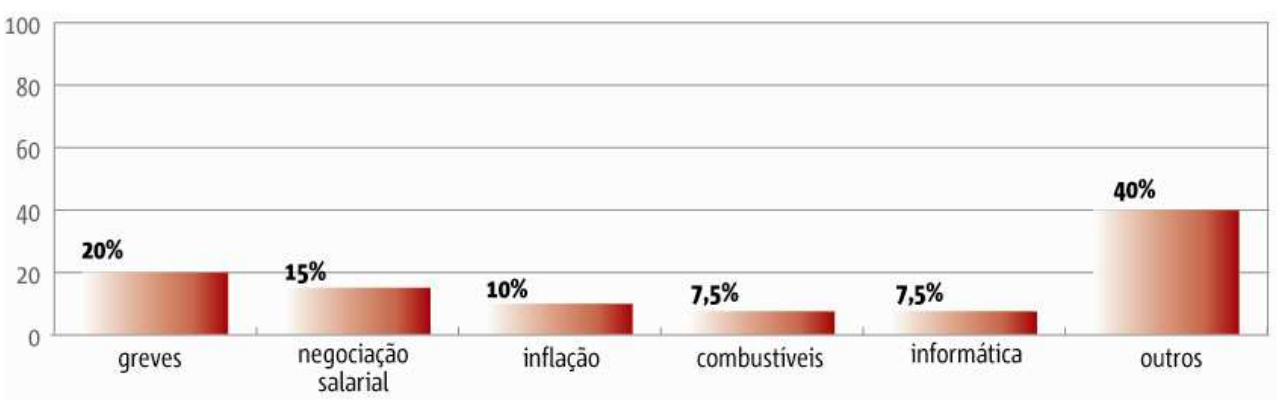

Figura 24. Temas de predomínio no noticiário, 1o. semestre de 1989.

b) Análise dos temas da amostragem do primeiro semestre de 1989

Notícias sobre greves/1989

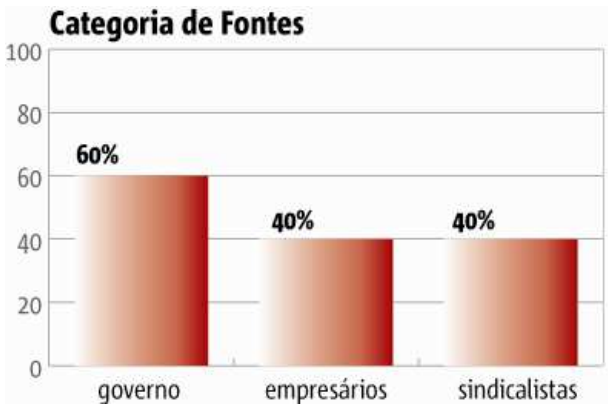

Figura 25. (a) Predominância por origem.

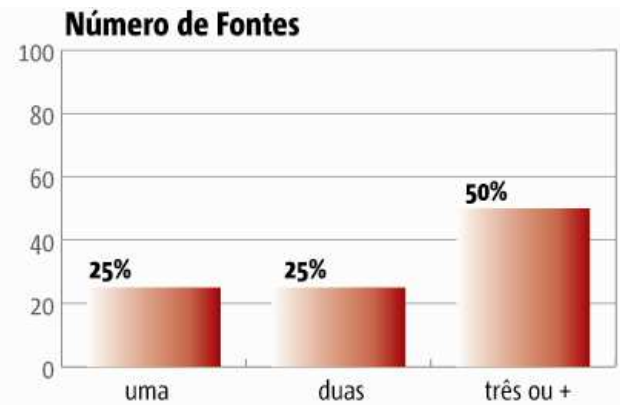

25 (b) Quantidade de fontes nas matérias. 
Notícias sobre negociação salarial/1989

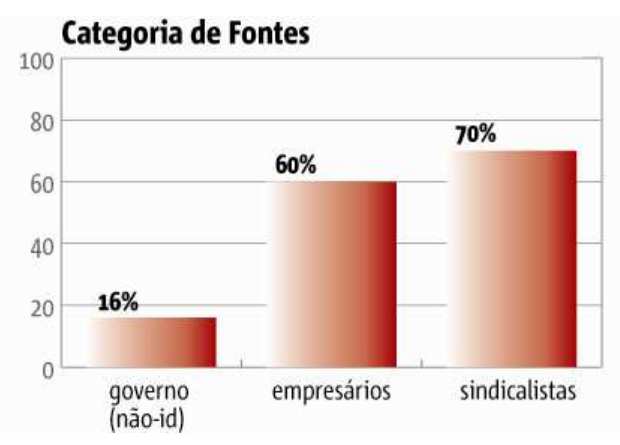

Figura 26. (a) Predominância por origem.

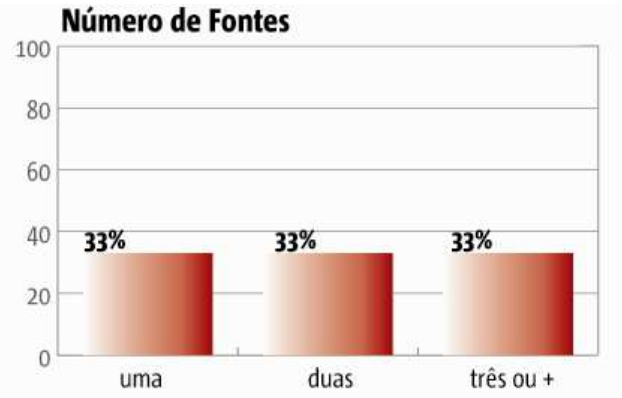

26 (b) Quantidade de fontes nas matérias.

Notícias sobre inflação/1989

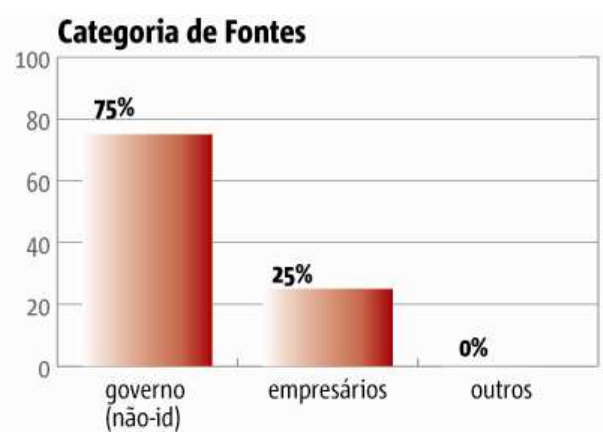

Figura 27. (a) Predominância por origem.

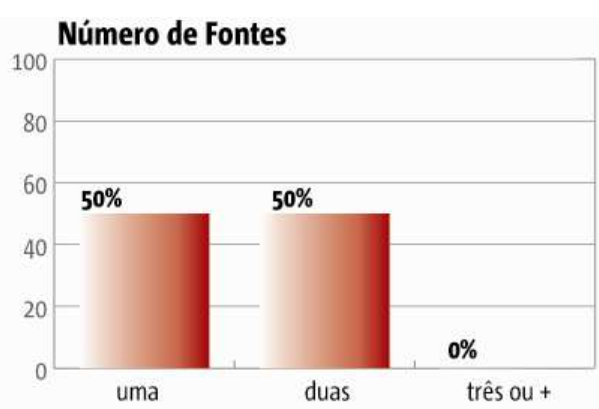

27 (b) Quantidade de fontes nas matérias.

Notícias sobre combustíveis/1989

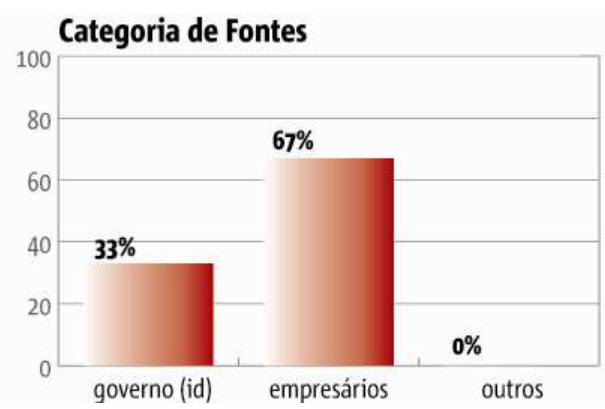

Figura 28. (a) Predominância por origem.

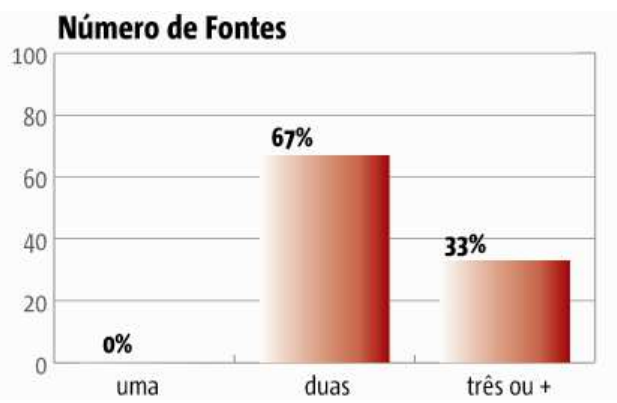

28 (b) Quantidade de fontes nas matérias. 
Notícias sobre informática/1989

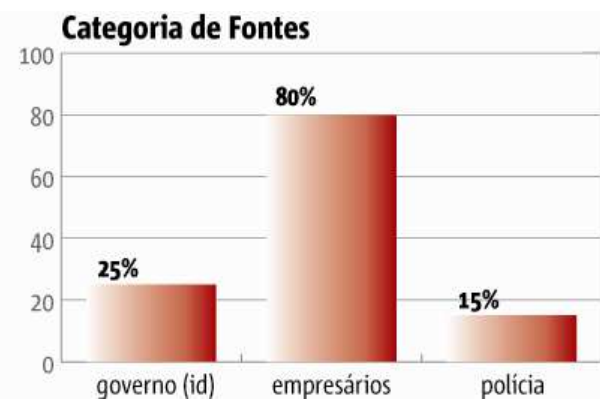

Figura 29. (a) Predominância por origem.

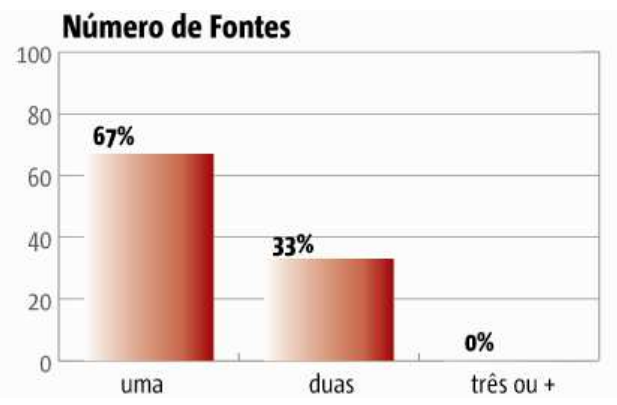

29 (b) Quantidade de fontes nas matérias.

a) Principais temas da amostra do noticiário do primeiro semestre de 1991

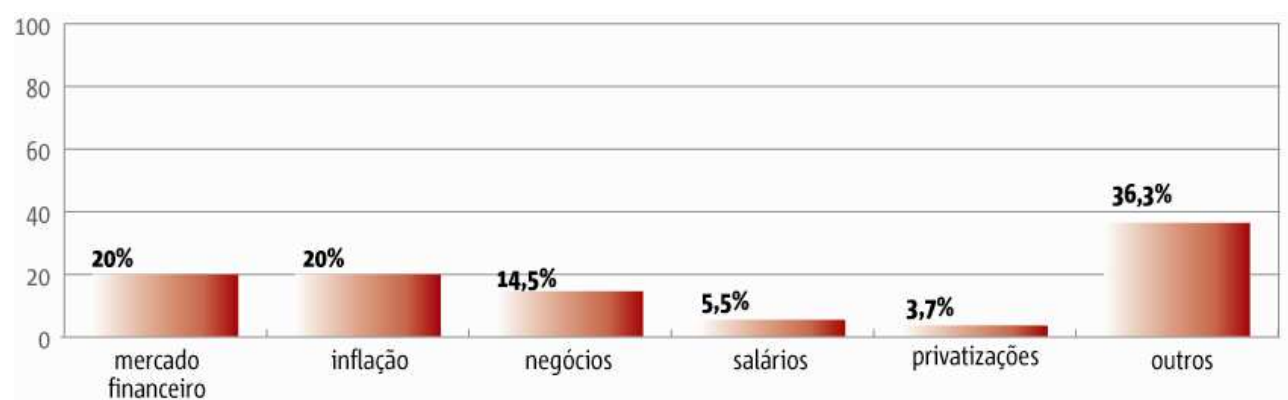

Figura 30. Temas de predomínio no noticiário, 1o. semestre de 1991.

b) Análise dos temas da amostragem do primeiro semestre de 1991

Notícias sobre mercado financeiro/1991

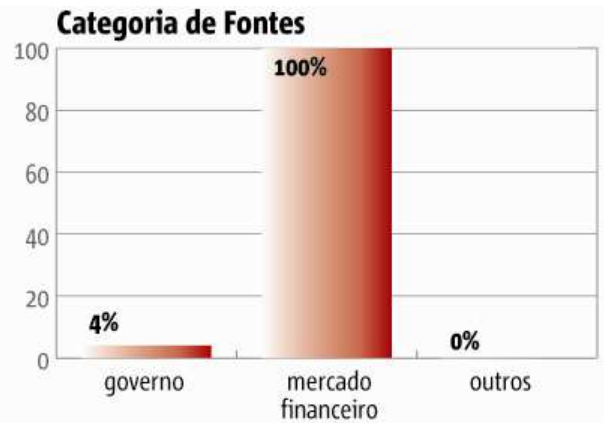

Figura 31. (a) Predominância por origem.

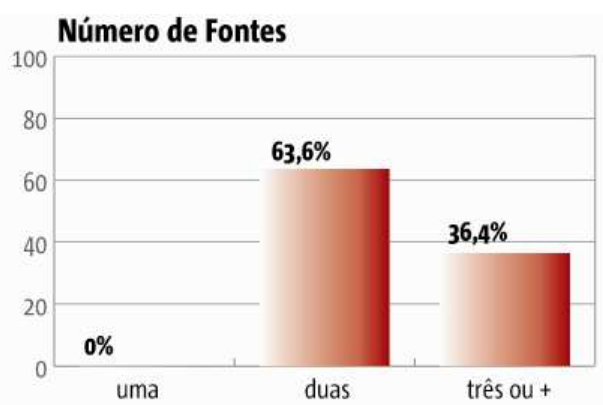

31 (b) Quantidade de fontes nas matérias. 
Notícias sobre inflação/1991

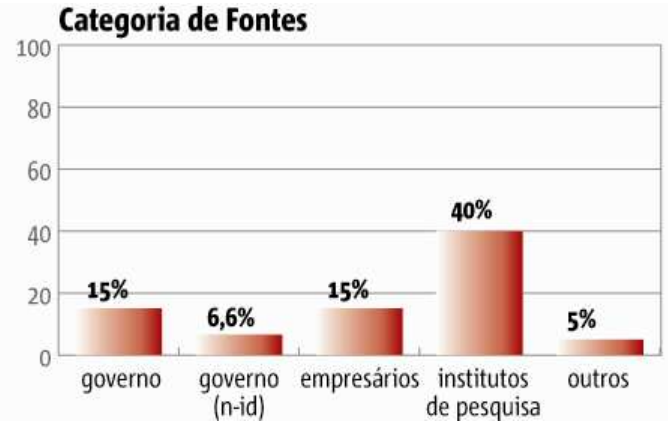

Figura 32. (a) Predominância por origem.

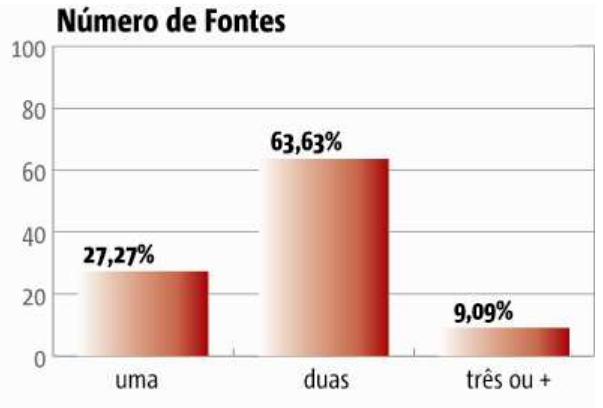

32 (b) Quantidade de fontes nas matérias.

Notícias sobre negócios/1991
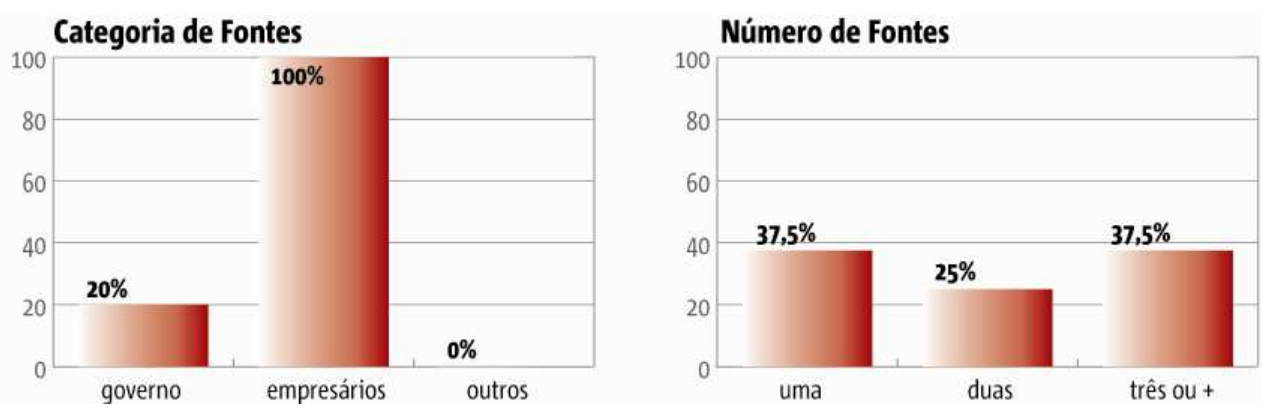

Figura 33. (a) Predominância por origem.

33 (b) Quantidade de fontes nas matérias.

Notícias sobre salários/1991
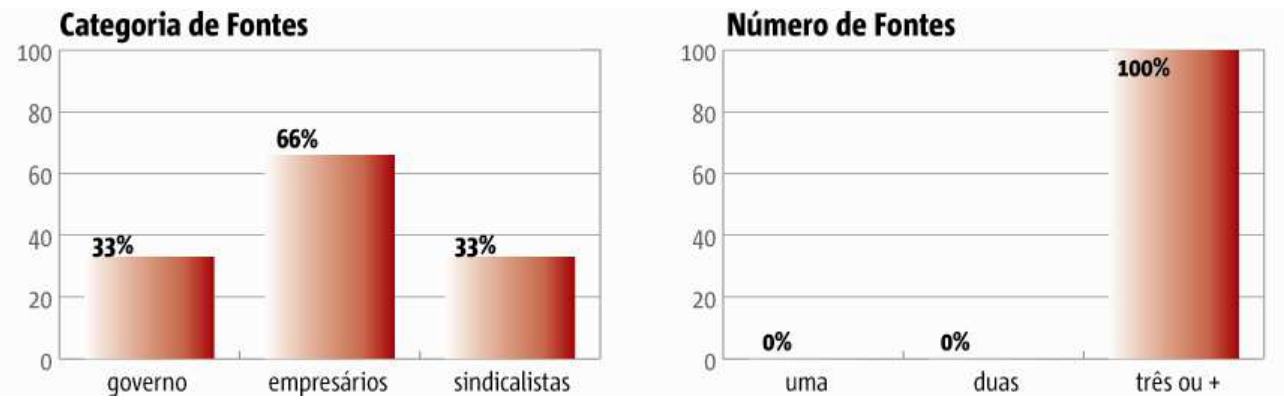

Figura 34. (a) Predominância por origem. 
Notícias sobre privatizações/1991

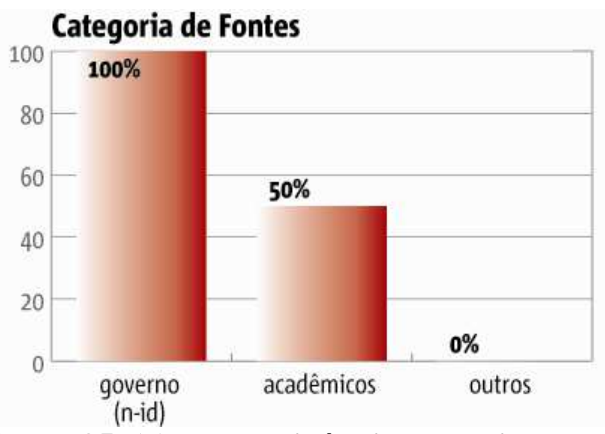

Figura 35. (a) Predominância por origem.

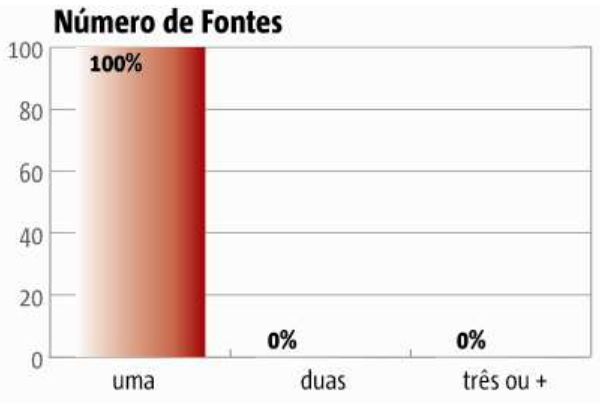

35 (b) Quantidade de fontes nas matérias.

a) Principais temas da amostra do noticiário do primeiro semestre de 1993

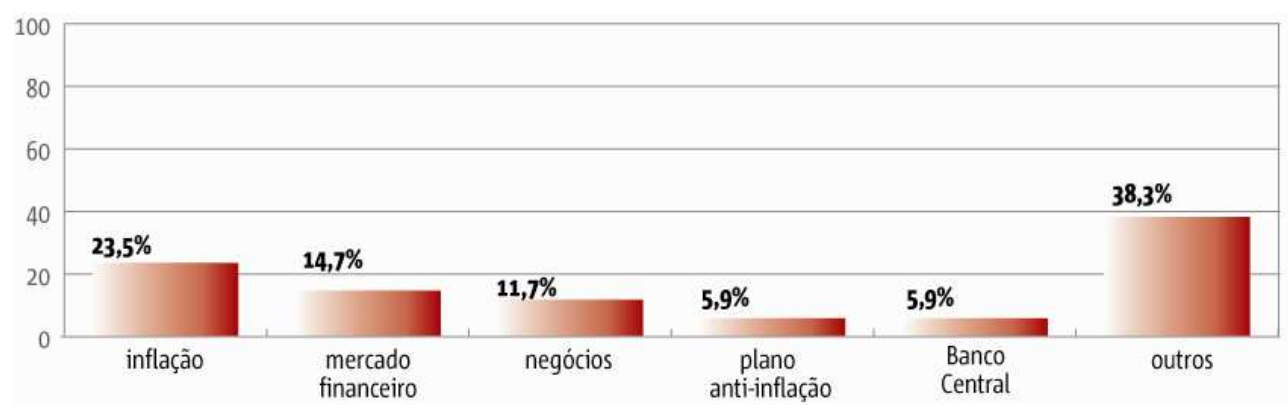

Figura 36. Temas de predomínio no noticiário, 1o. semestre de 1993.

b) Análise dos temas da amostragem do primeiro semestre de 1993

Notícias sobre inflação/1993

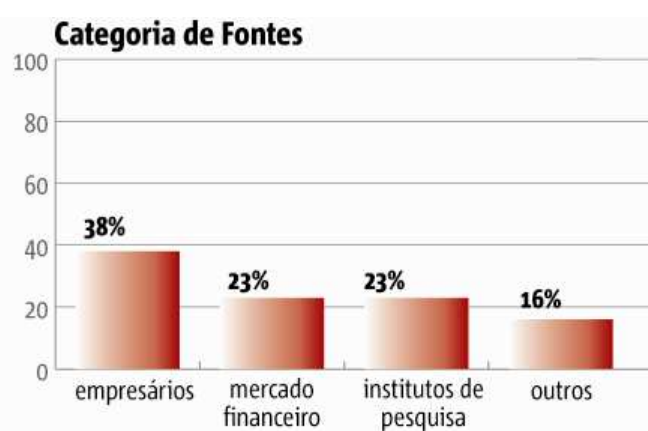

Figura 37. (a) Predominância por origem.

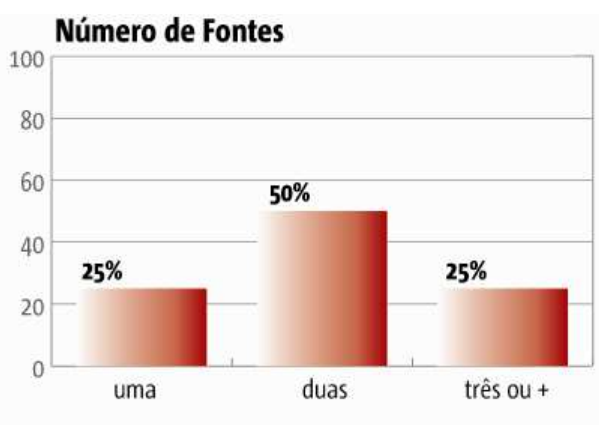

37 (b) Quantidade de fontes nas matérias. 
Notícias sobre mercado financeiro/1993

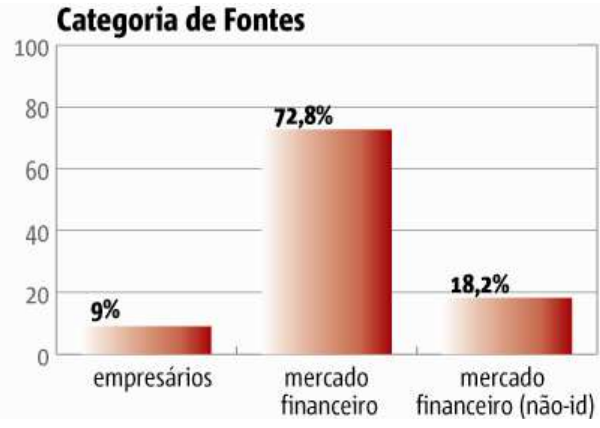

Figura 38. (a) Predominância por origem.

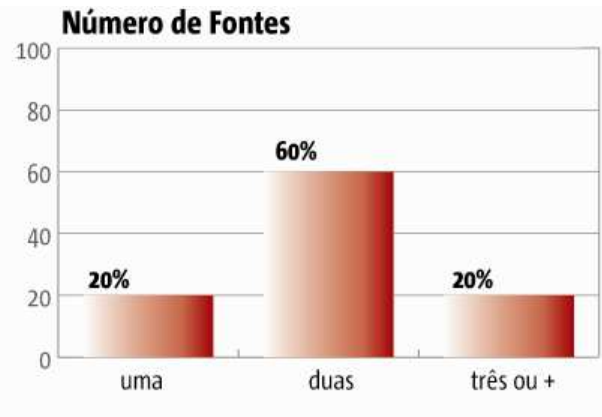

38 (b) Quantidade de fontes nas matérias.

Notícias sobre negócios/1993

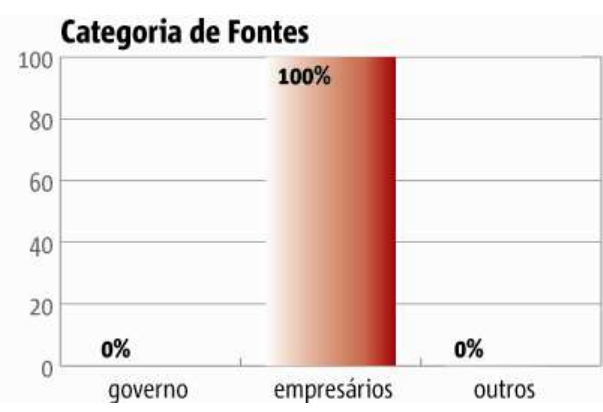

Figura 39. (a) Predominância por origem.

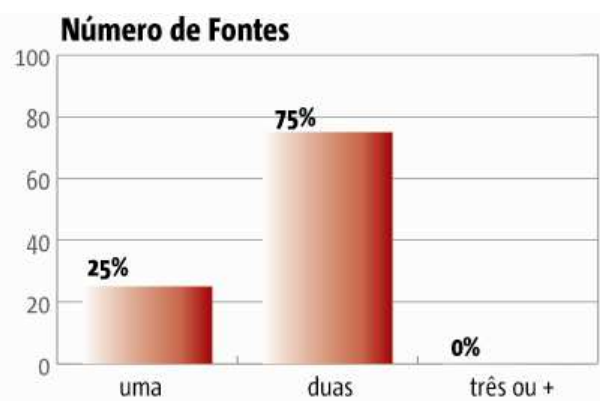

39 (b) Quantidade de fontes nas matérias.

Notícias sobre plano antiinflação/1993

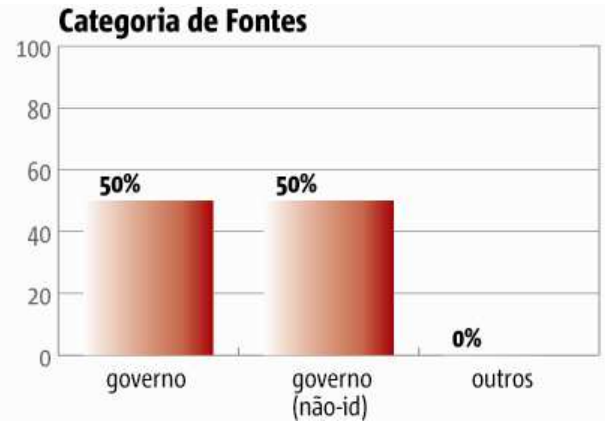

Figura 40. (a) Predominância por origem.

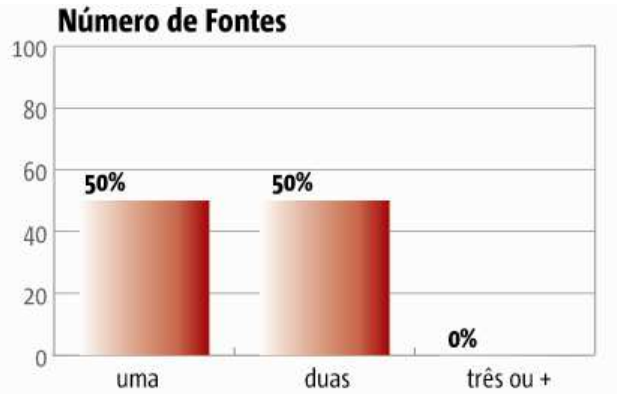

40 (b) Quantidade de fontes nas matérias. 
Notícias sobre Banco Central/1993

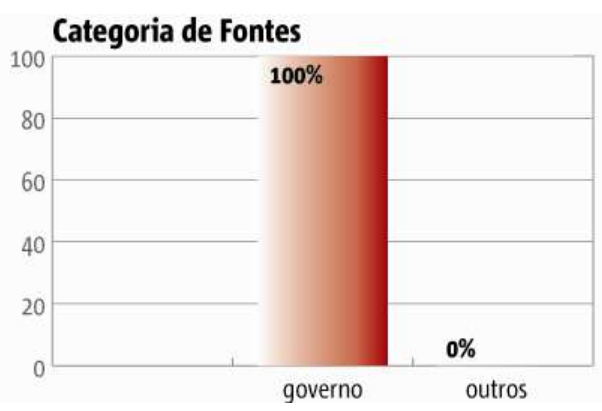

Figura 41. (a) Predominância por origem.

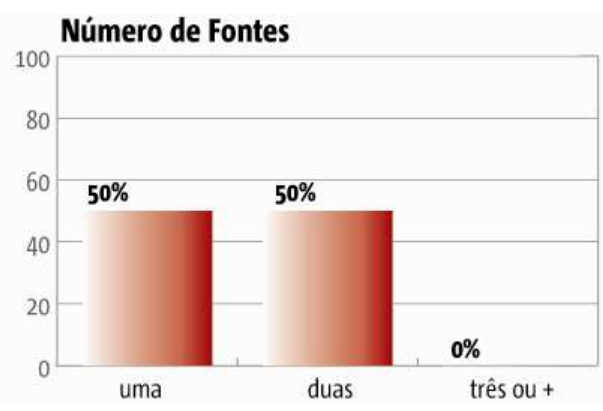

41 (b) Quantidade de fontes nas matérias.

a) Principais temas da amostra do noticiário do primeiro semestre de 1995

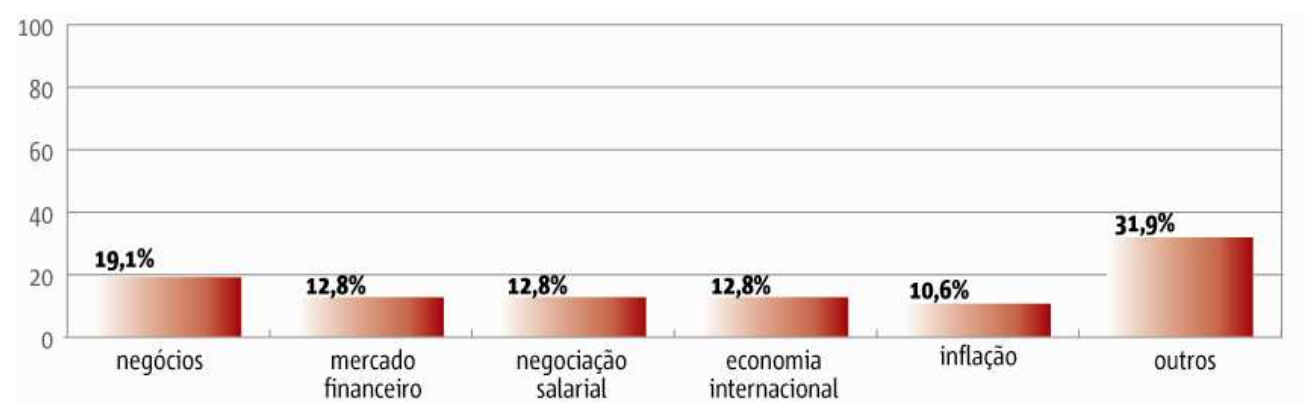

Figura 42. Temas de predomínio no noticiário, 1o. semestre de 1995. 
b) Análise dos temas da amostragem do primeiro semestre de 1995

Notícias sobre negócios/1995

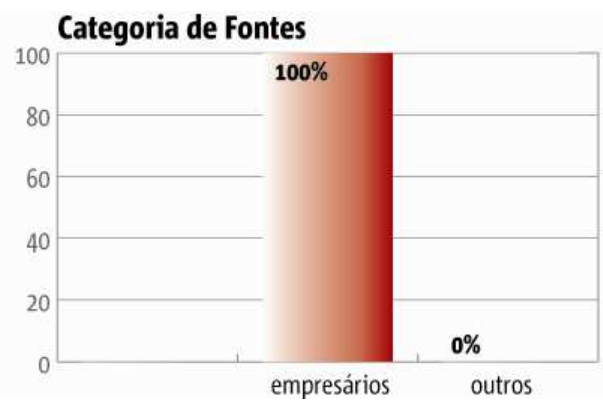

Figura 43. (a) Predominância por origem.

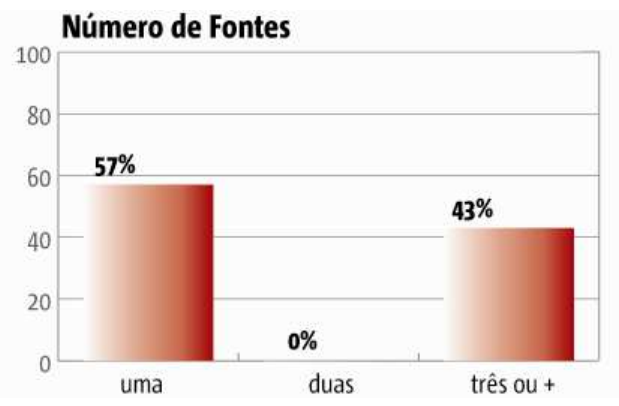

43 (b) Quantidade de fontes nas matérias.

Notícias sobre mercado financeiro/1995

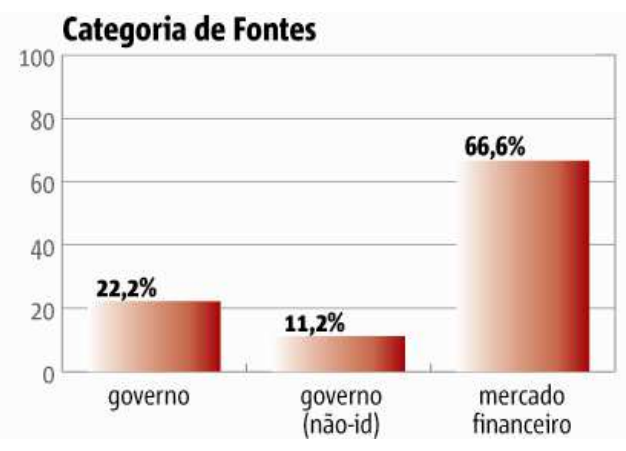

Figura 44. (a) Predominância por origem.

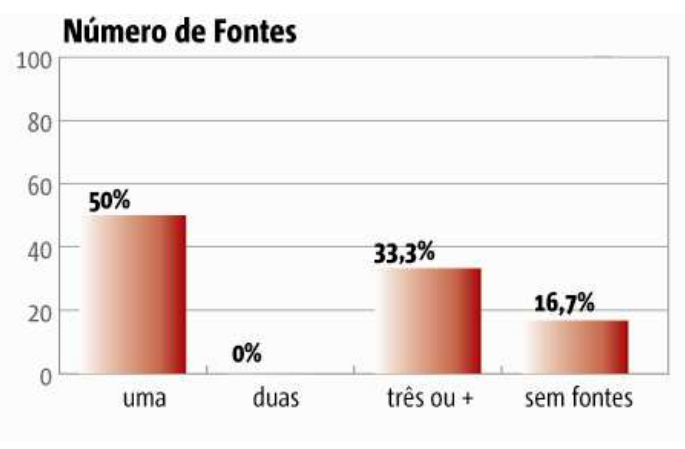

44 (b) Quantidade de fontes nas matérias.

Notícias sobre negociação salarial/1995

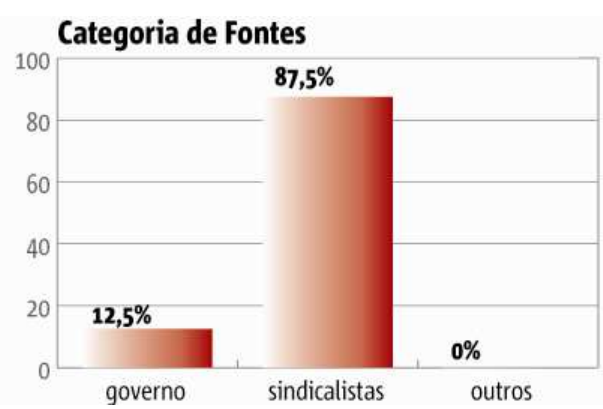

Figura 45. (a) Predominância por origem.

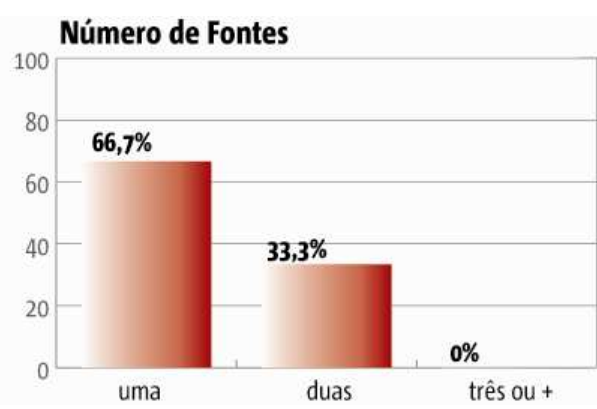

45 (b) Quantidade de fontes nas matérias. 
Notícias sobre economia internacional/1995

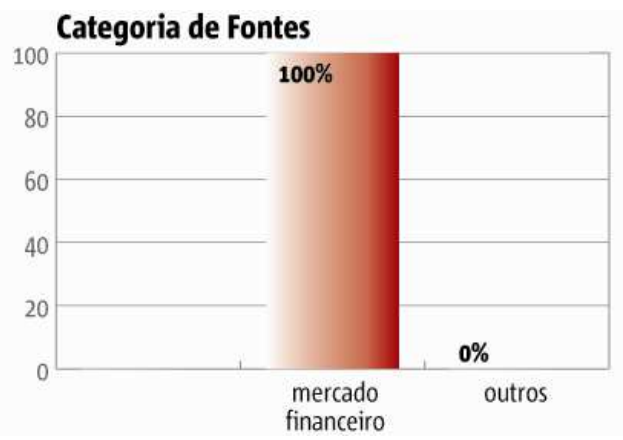

Figura 46. (a) Predominância por origem.

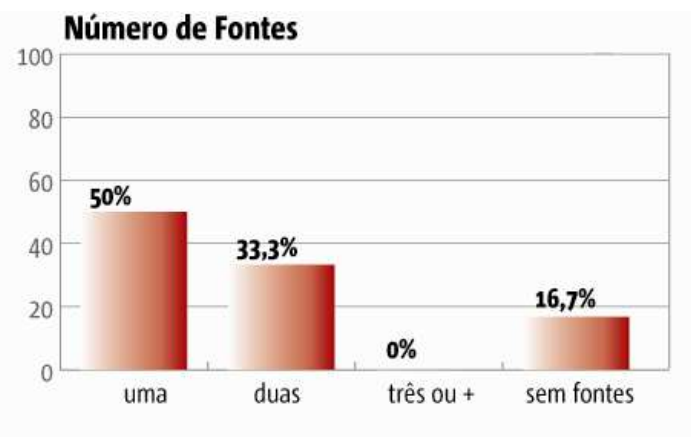

46 (b) Quantidade de fontes nas matérias.

Notícias sobre inflação/1995

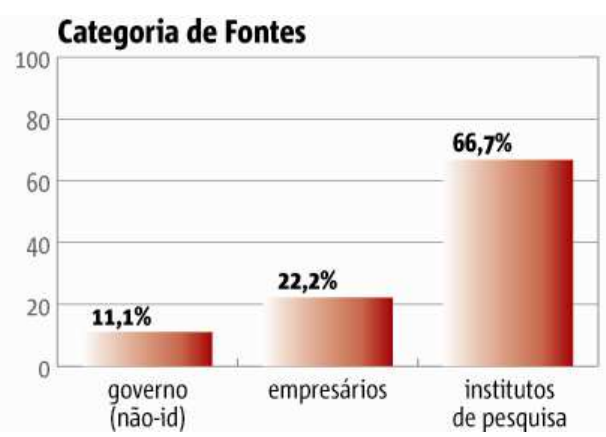

Figura 47. (a) Predominância por origem.

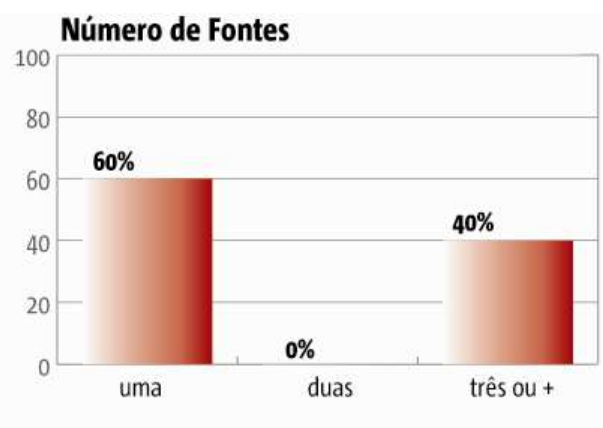

47 (b) Quantidade de fontes nas matérias.

\section{a) Principais temas da amostra do noticiário do primeiro semestre de 1997}

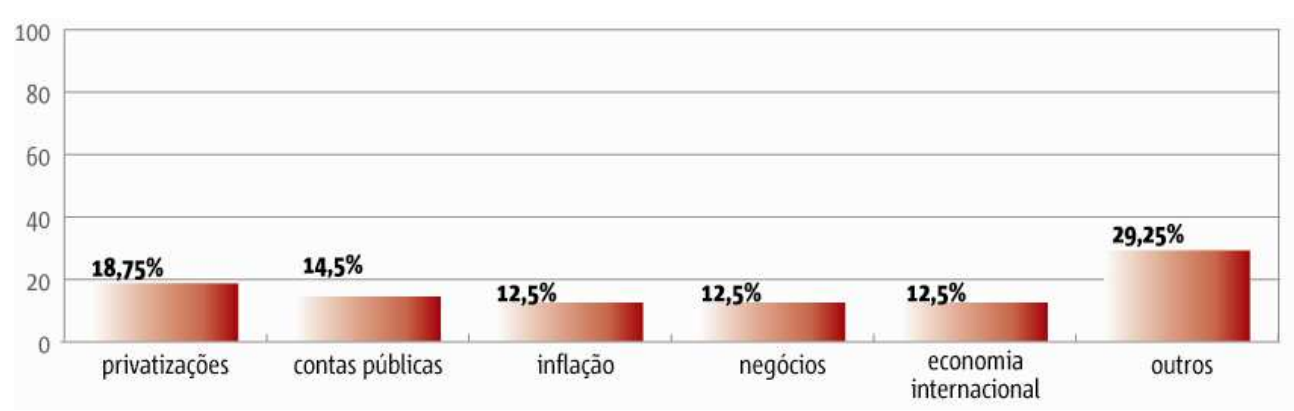

Figura 48. Temas de predomínio no noticiário, 1o. semestre de 1997. 
b) Análise dos temas da amostragem do primeiro semestre de 1997

Notícias sobre privatizações/1997

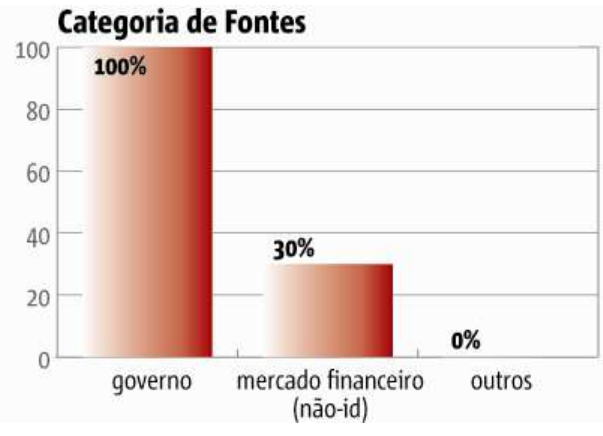

Figura 49. (a) Predominância por origem.

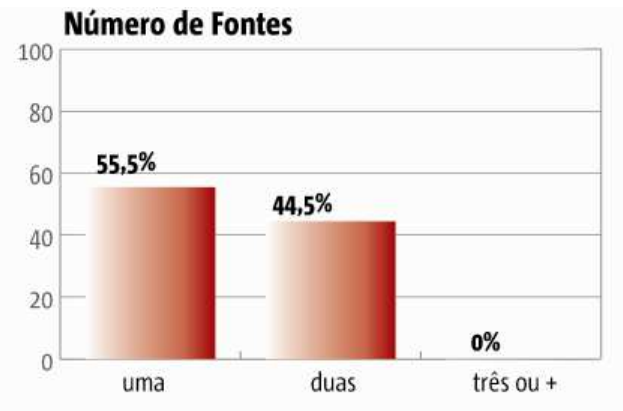

49 (b) Quantidade de fontes nas matérias.

Notícias sobre contas públicas/1997

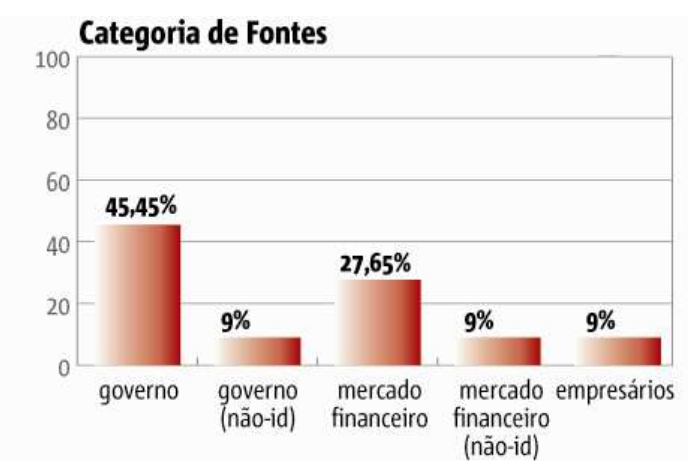

Figura 50. (a) Predominância por origem.

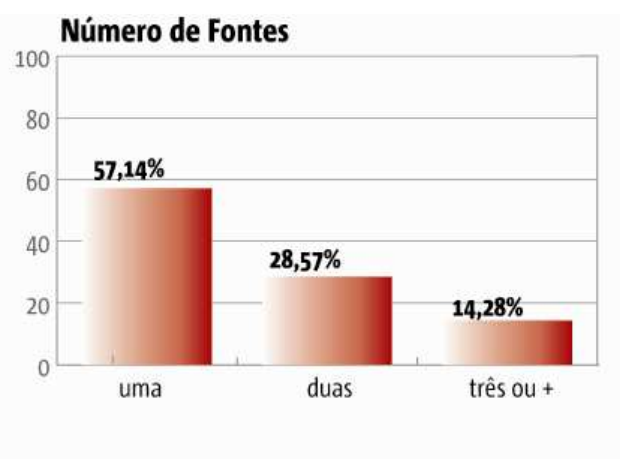

50 (b) Quantidade de fontes nas matérias.

Notícias sobre inflação/1997

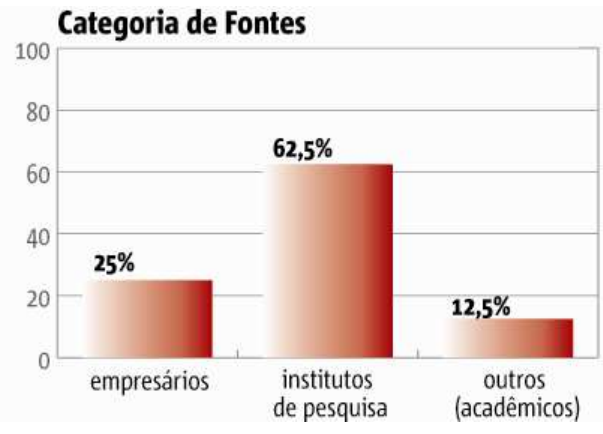

Figura 51. (a) Predominância por origem.

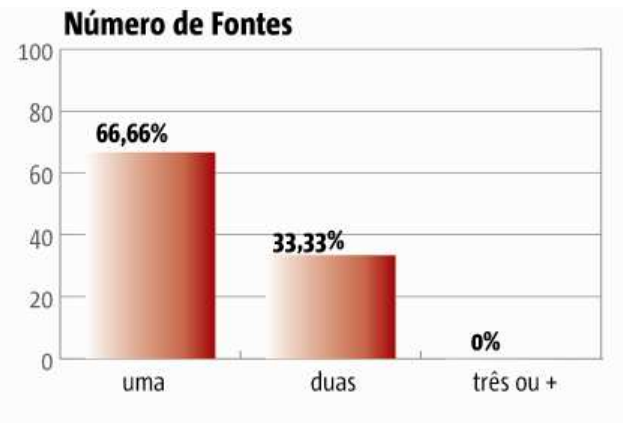

51 (b) Quantidade de fontes nas matérias. 
Notícias sobre economia internacional/1997

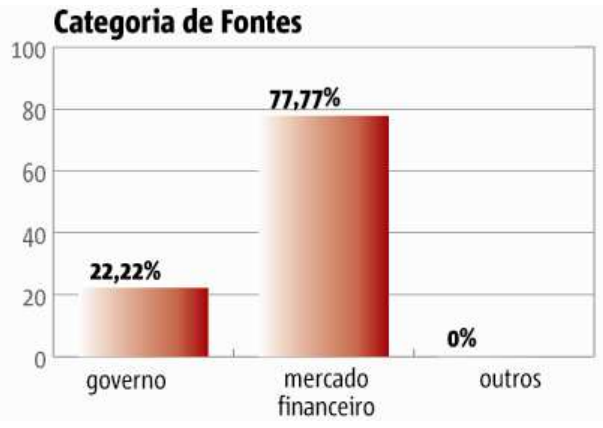

Figura 52. (a) Predominância por origem.

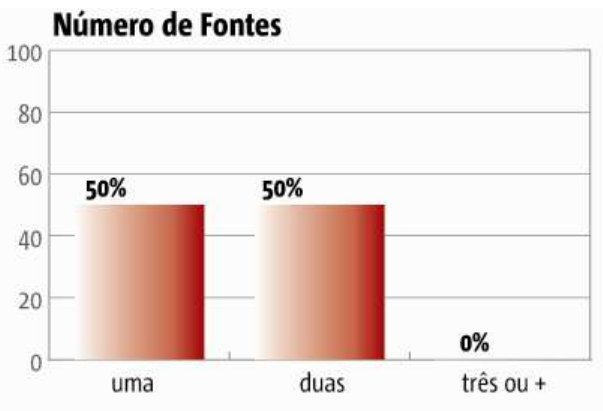

52 (b) Quantidade de fontes nas matérias.

Notícias sobre negócios/1997

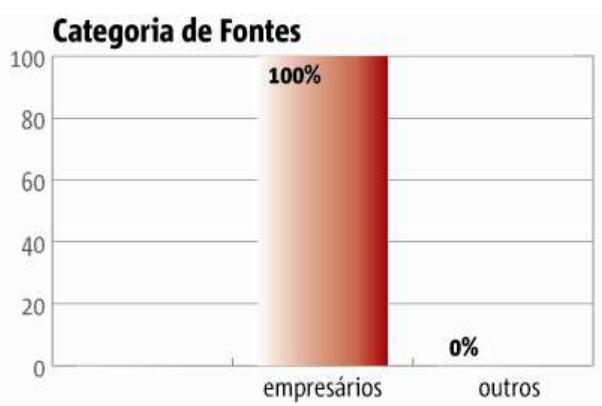

Figura 53. (a) Predominância por origem.

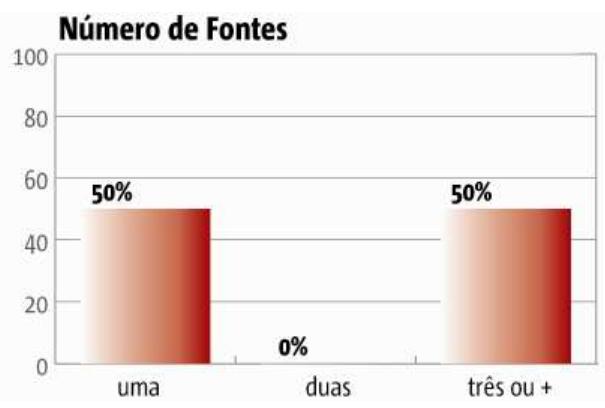

53 (b) Quantidade de fontes nas matérias.

a) Principais temas da amostra do noticiário do primeiro semestre de 1999

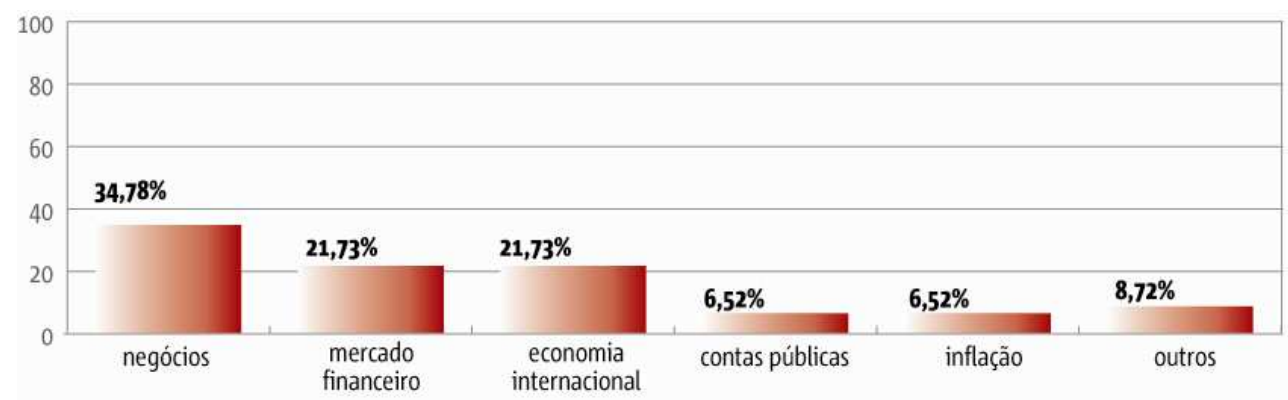

Figura 54. Temas de predomínio no noticiário, 1o. semestre de 1999. 
b) Análise dos temas da amostragem do primeiro semestre de 1999

Notícias sobre negócios/1999

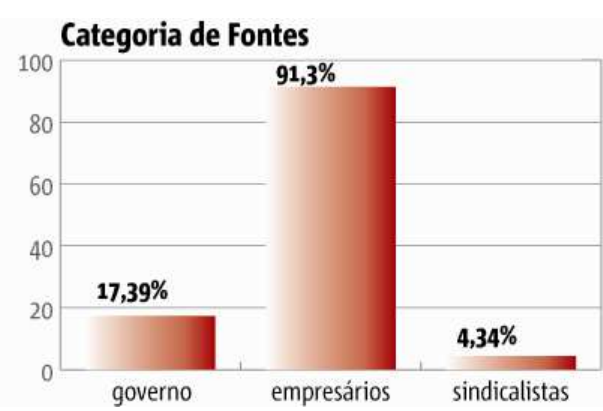

Figura 55. (a) Predominância por origem.

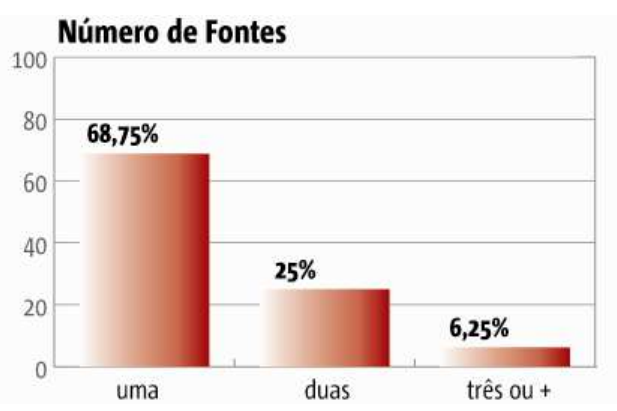

55 (b) Quantidade de fontes nas matérias.

Notícias sobre mercado financeiro/1999
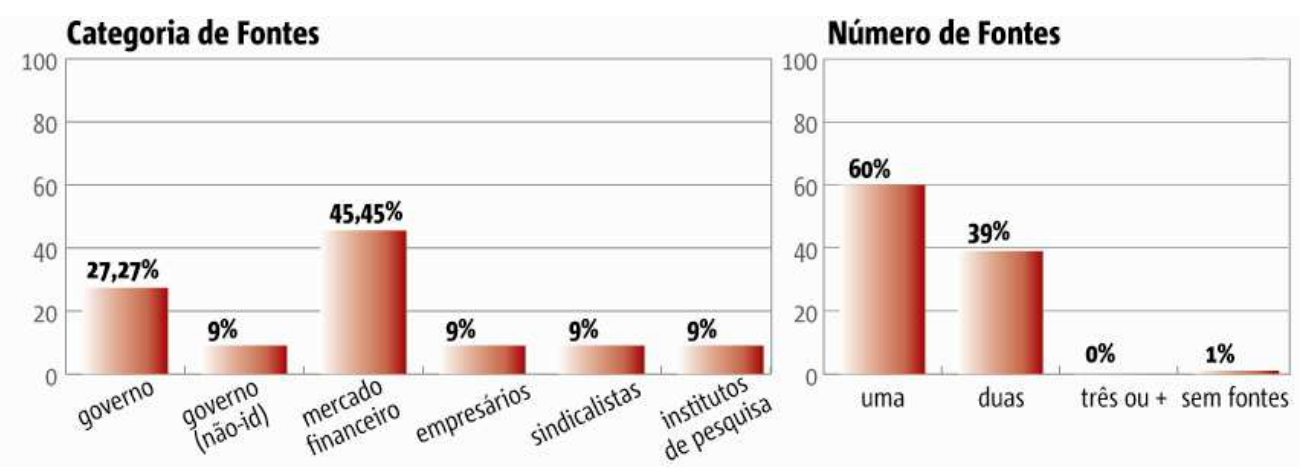

Figura 56. (a) Predominância por origem.

56 (b) Quantidade de fontes nas matérias.

Notícias sobre economia internacional/1999

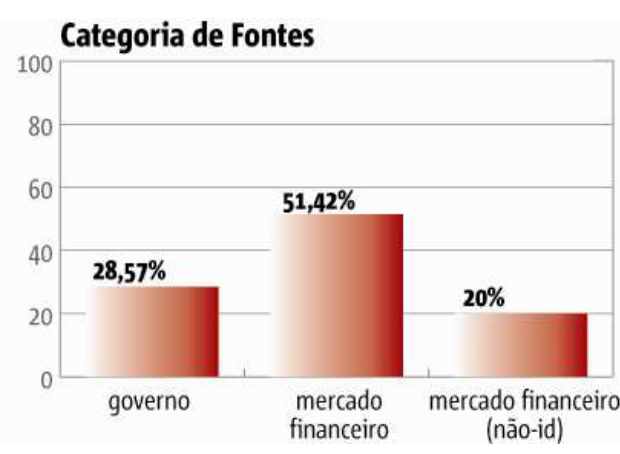

Figura 57. (a) Predominância por origem.

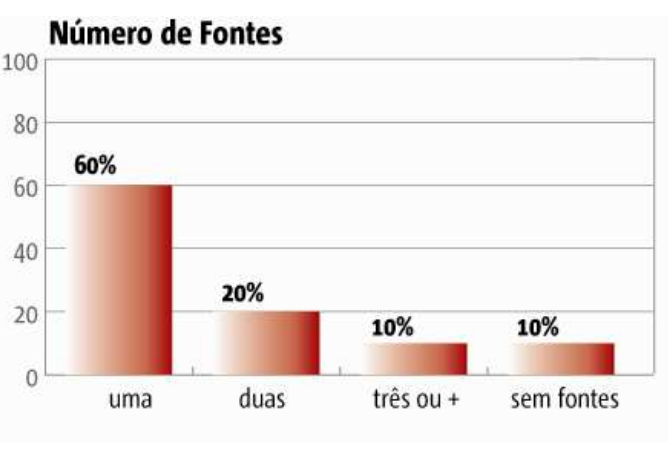

57 (b) Quantidade de fontes nas matérias. 149 
Notícias sobre contas públicas/1999

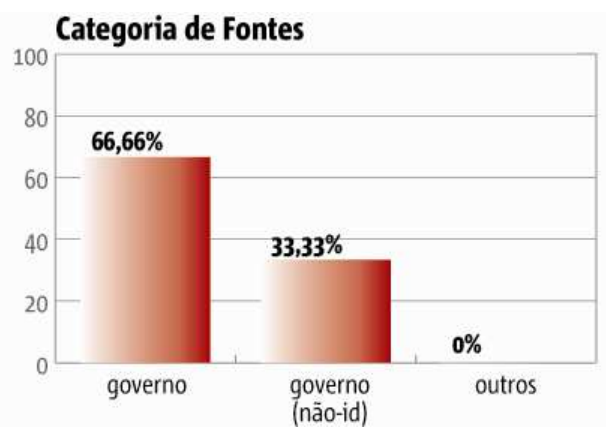

Figura 58 (a) Predominância por origem.

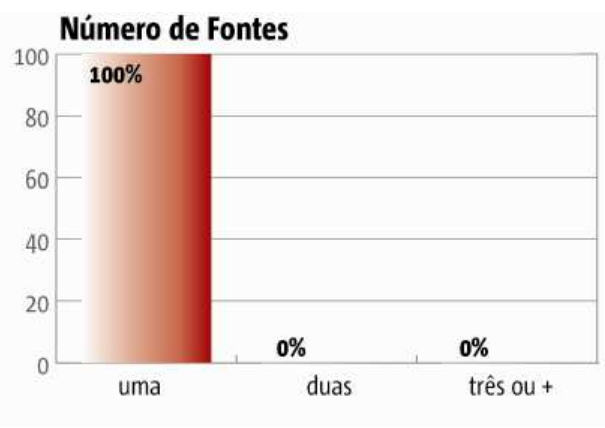

58 (b) Quantidade de fontes nas matérias.

Notícias sobre inflação/1999

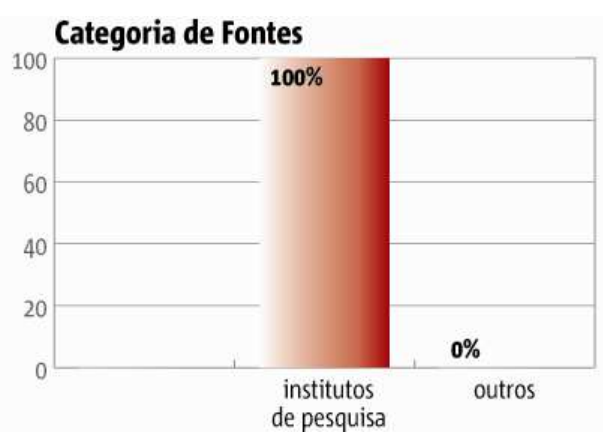

Figura 59. (a) Predominância por origem.

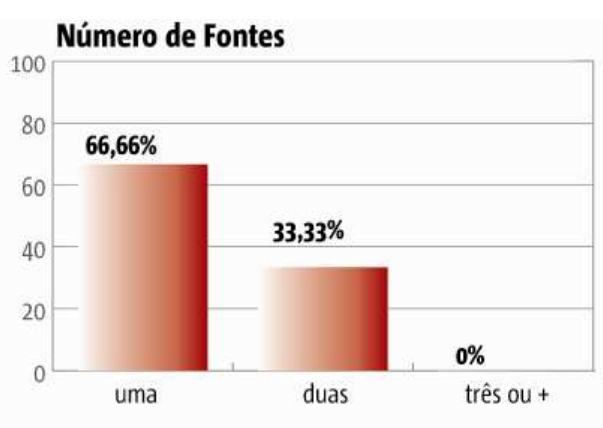

59 (b) Quantidade de fontes nas matérias.

a) Principais temas da amostra do noticiário do primeiro semestre de 2001

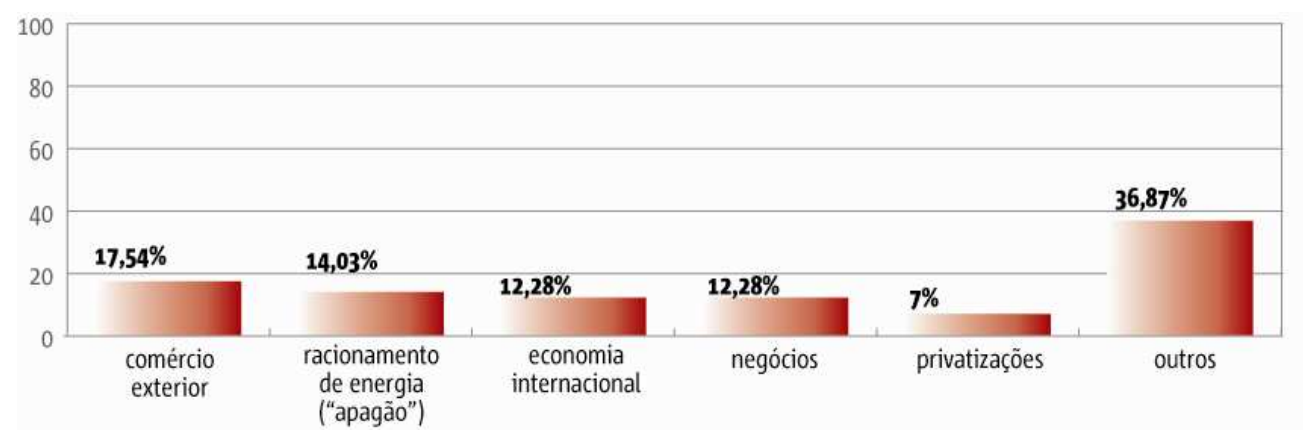

Figura 60. Temas de predomínio no noticiário, 1o. semestre de 2001. 
b) Análise dos temas da amostragem do primeiro semestre de 2001

Notícias sobre comércio exterior/2001
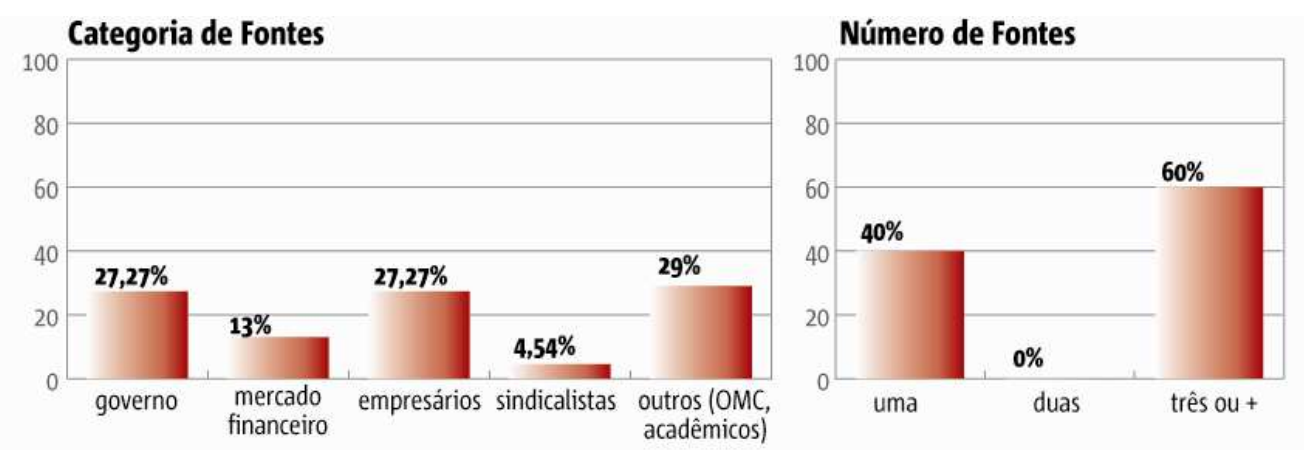

Figura 61. (a) Predominância por origem.

61 (b) Quantidade de fontes nas matérias.

Notícias sobre racionamento de energia/2001
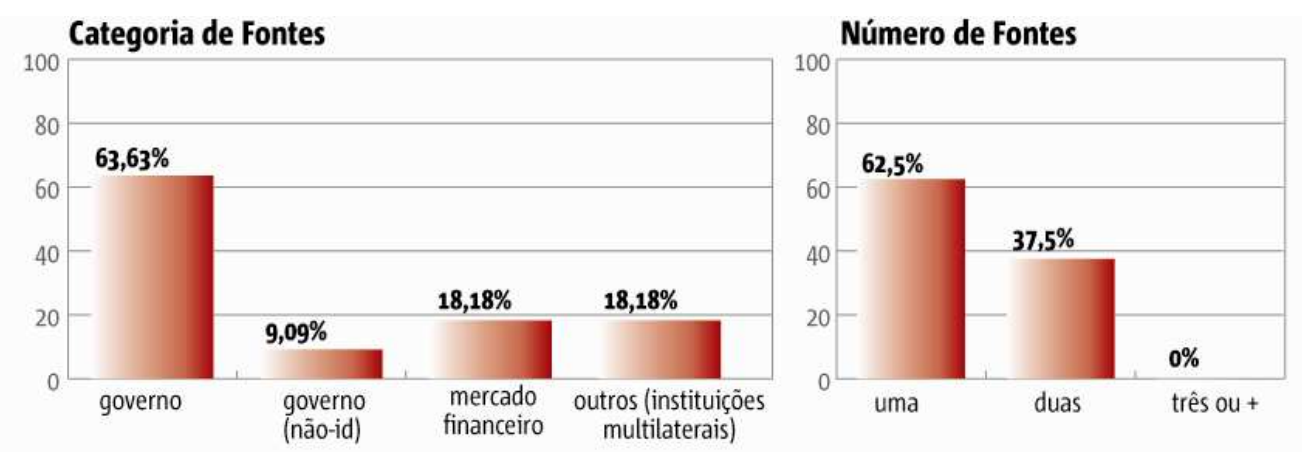

Figura 62. (a) Predominância por origem.

62 (b) Quantidade de fontes nas matérias.

Notícias sobre economia internacional/2001
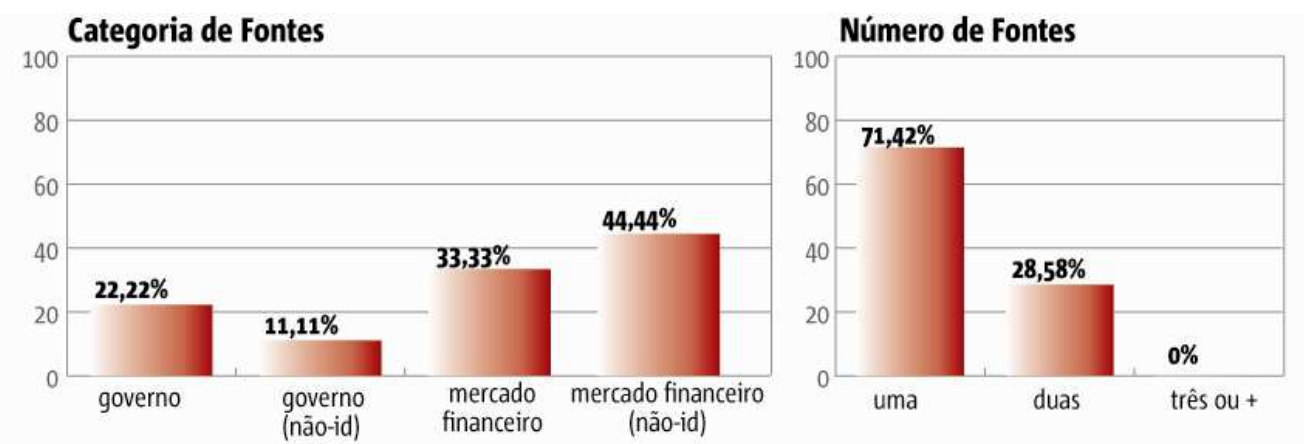

Figura 63. (a) Predominância por origem.

63 (b) Quantidade de fontes nas matérias. 
Notícias sobre negócios/2001

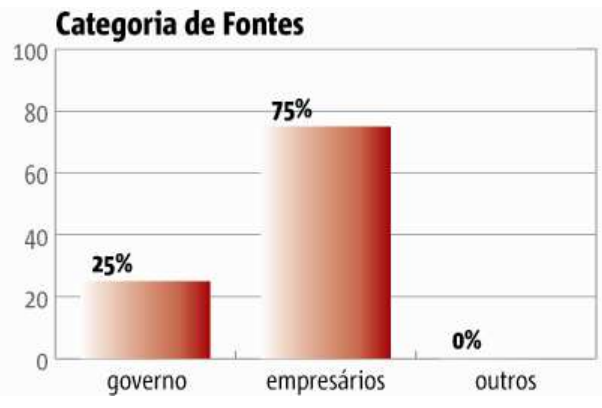

Figura 64. (a) Predominância por origem.

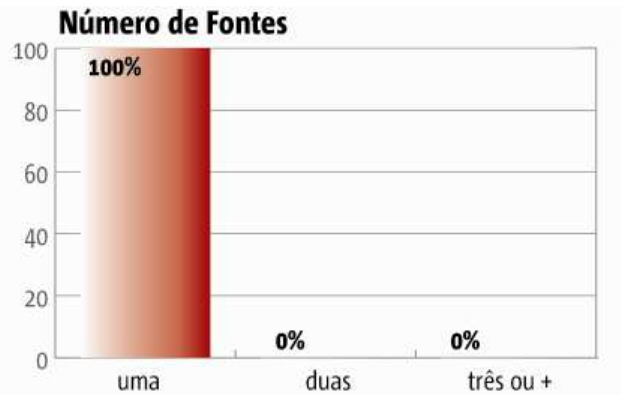

64 (b) Quantidade de fontes nas matérias.

Notícias sobre privatizações/2001
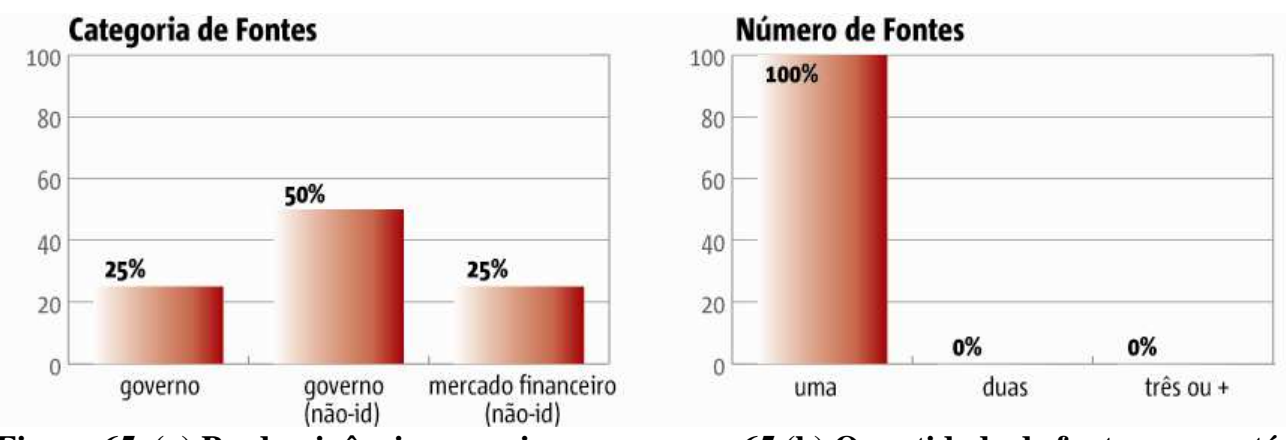

Figura 65. (a) Predominância por origem.

65 (b) Quantidade de fontes nas matérias. 


\section{Folha de S.Paulo}

a) Principais temas da amostra do noticiário do primeiro semestre de 1990

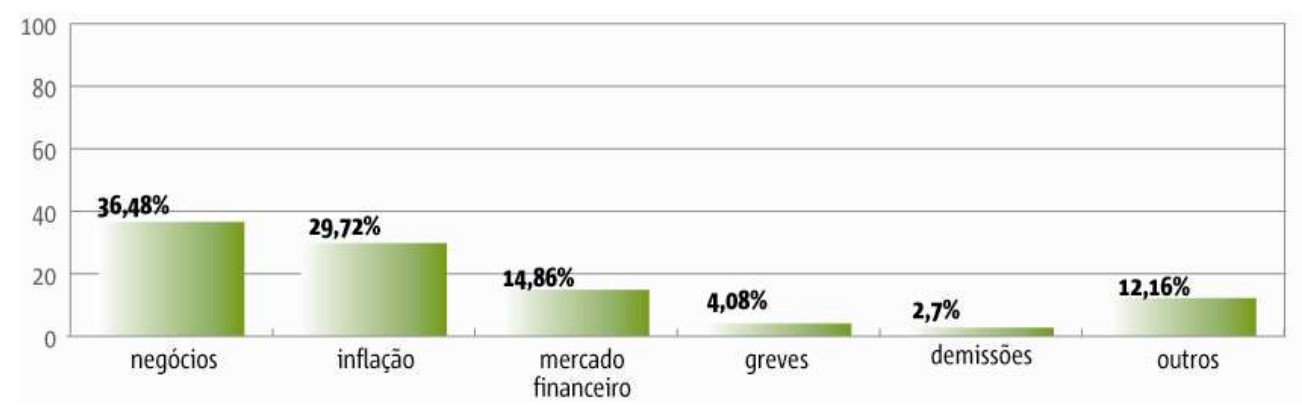

Figura 66. Temas de predomínio no noticiário, 1o. semestre de 1990.

b) Análise dos temas da amostragem do primeiro semestre de 1990

Notícias sobre negócios/1990

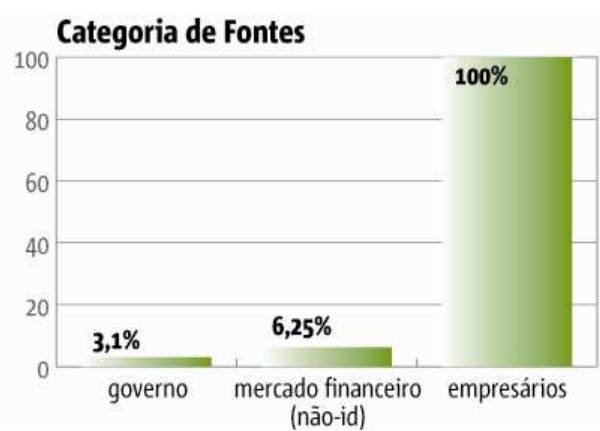

Figura 67. (a) Predominância por origem.

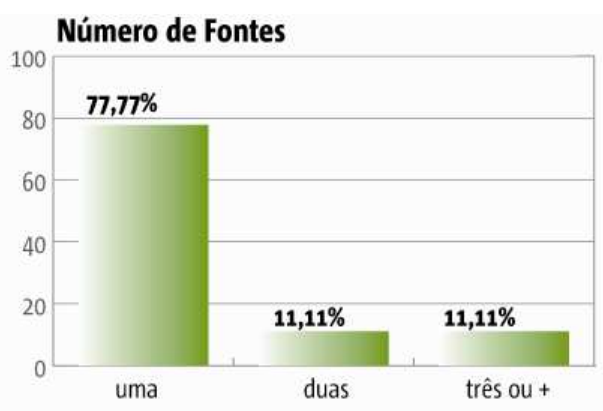

67 (b) Quantidade de fontes nas matérias.

Notícias sobre inflação/1990

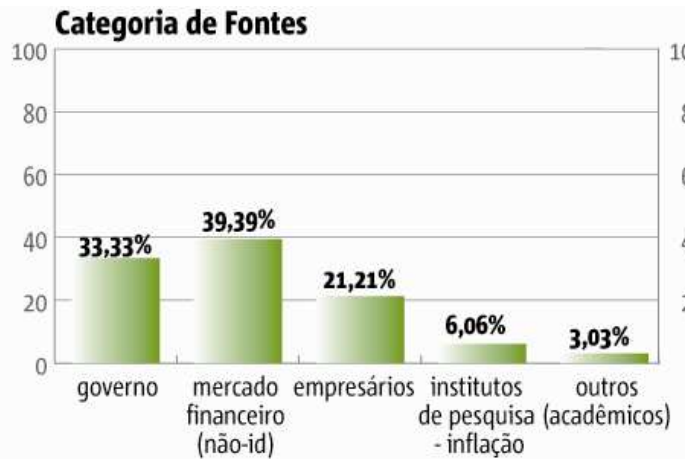

Figura 68. (a) Predominância por origem.

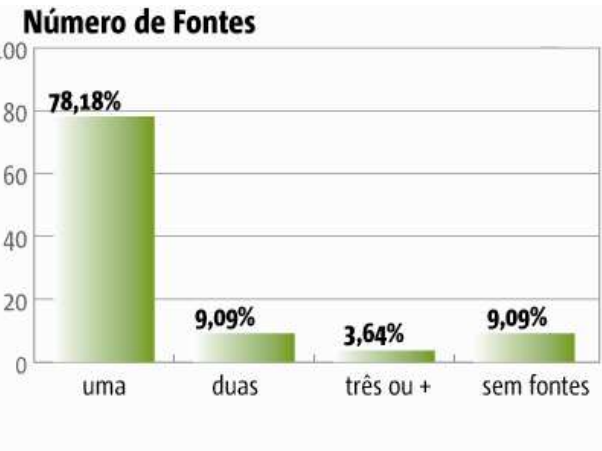

68 (b) Quantidade de fontes nas matérias. 
Notícias sobre mercado financeiro/1990

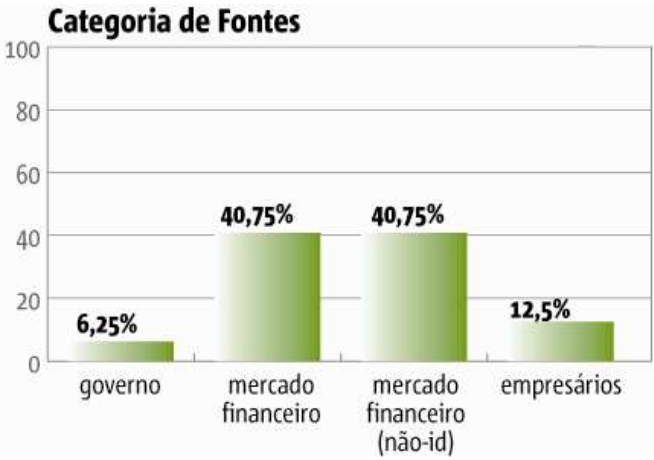

Figura 69. (a) Predominância por origem.

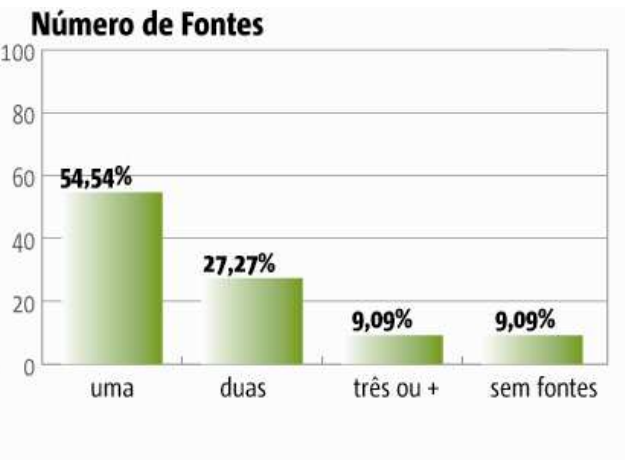

69 (b) Quantidade de fontes nas matérias.

Notícias sobre greves/1990

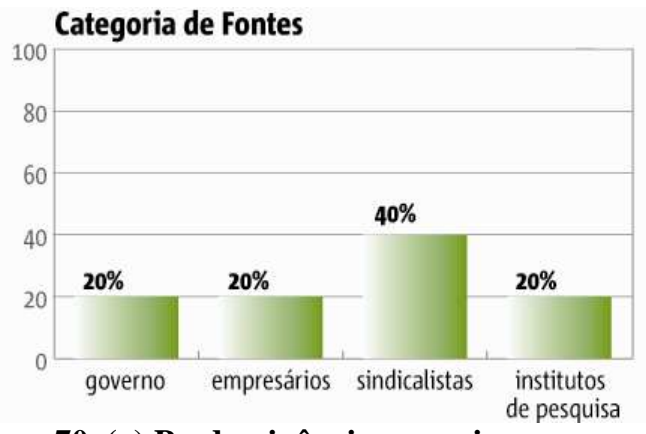

Figura 70. (a) Predominância por origem.

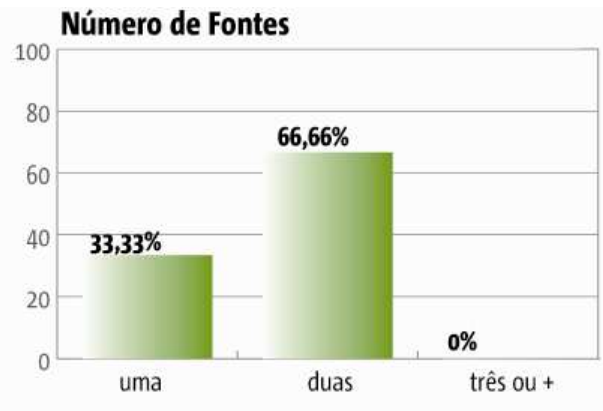

70 (b) Quantidade de fontes nas matérias.

Notícias sobre demissões/nível de emprego/1990

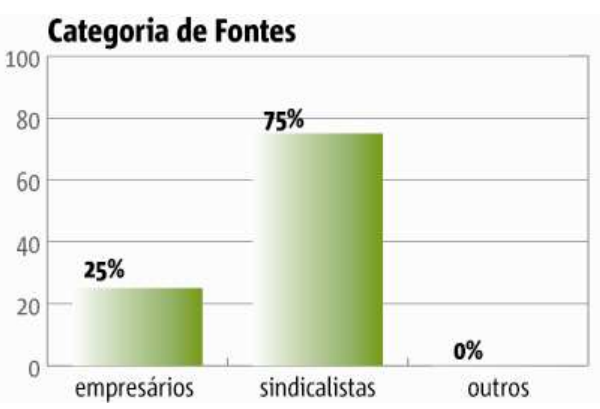

Figura 71. (a) Predominância por origem.

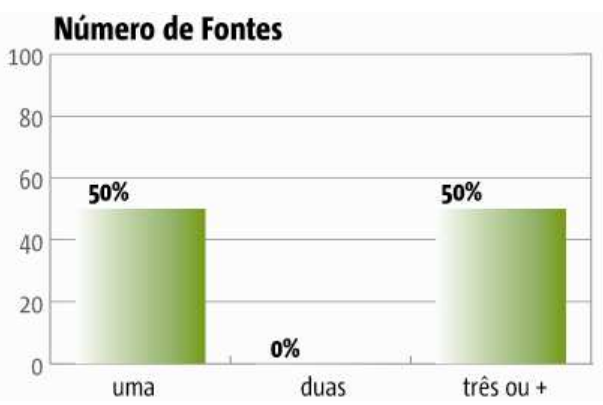

71 (b) Quantidade de fontes nas matérias. 
a) Principais temas da amostra do noticiário do primeiro semestre de 1992

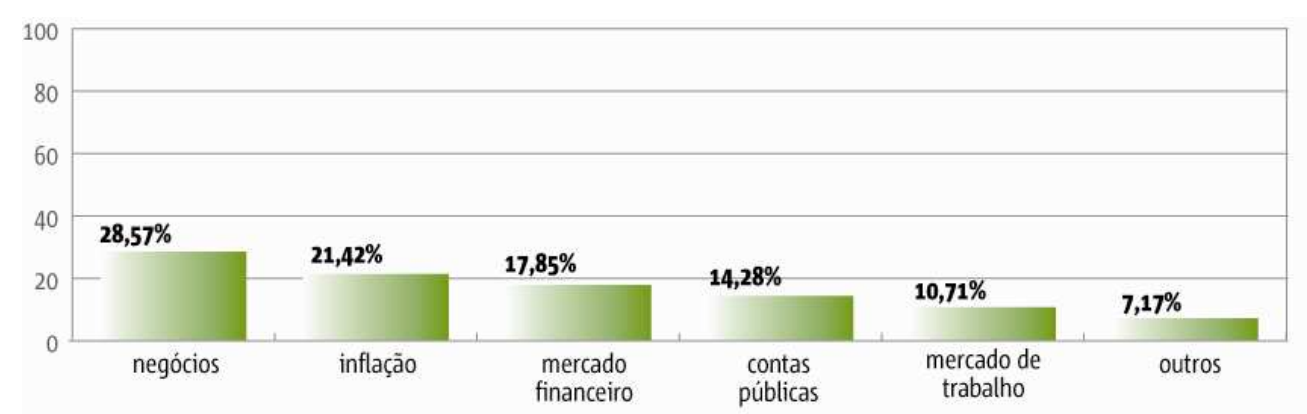

Figura 72. Temas de predomínio no noticiário, 1o. semestre de 1992.

b) Análise dos temas da amostragem do primeiro semestre de 1992

Notícias sobre negócios/1992

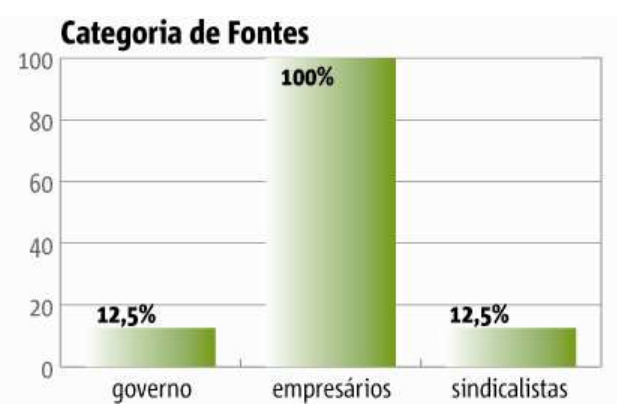

Figura 73. (a) Predominância por origem.

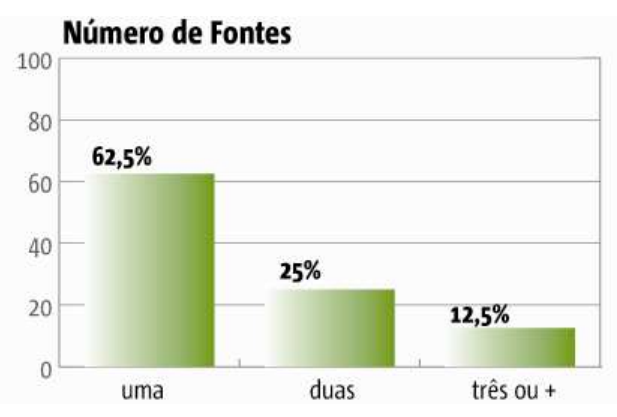

73 (b) Quantidade de fontes nas matérias. 
Notícias sobre inflação/preços/1992

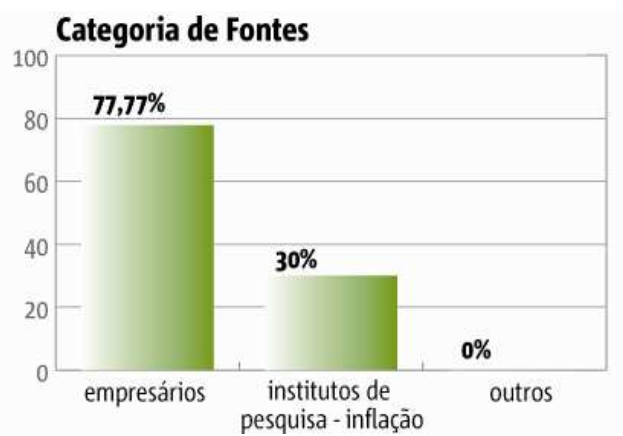

Figura 74. (a) Predominância por origem.

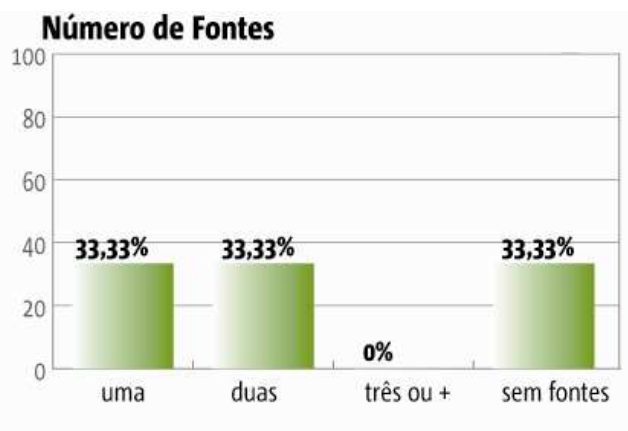

74 (b) Quantidade de fontes nas matérias.

Notícias sobre mercado financeiro/1992

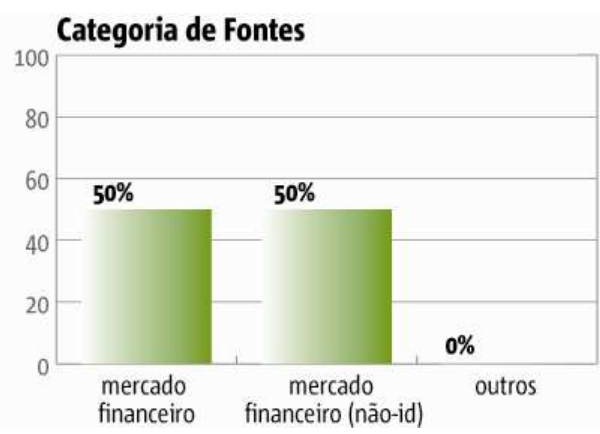

Figura 75. (a) Predominância por origem.

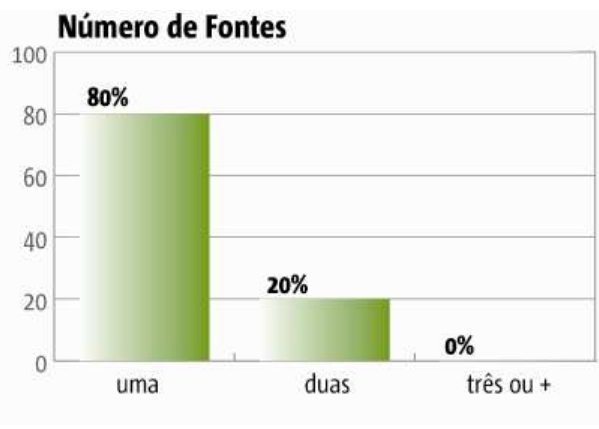

75 (b) Quantidade de fontes nas matérias.

Notícias sobre contas públicas/1992

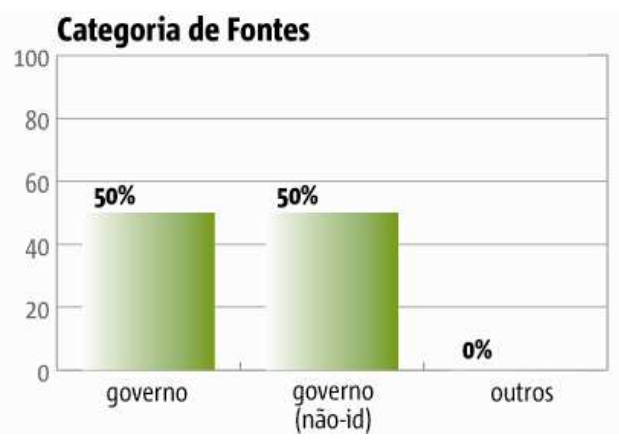

Figura 76. (a) Predominância por origem.

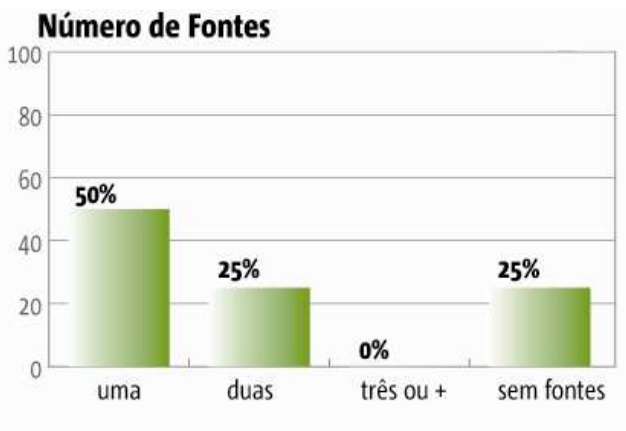

76 (b) Quantidade de fontes nas matérias. 
Notícias sobre mercado de trabalho/1992

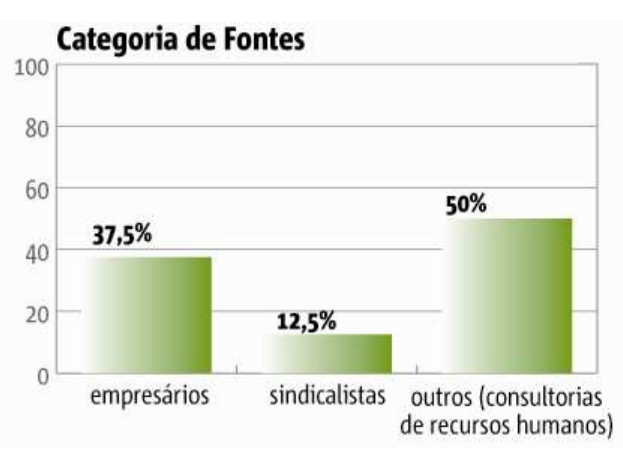

Figura 77. (a) Predominância por origem.

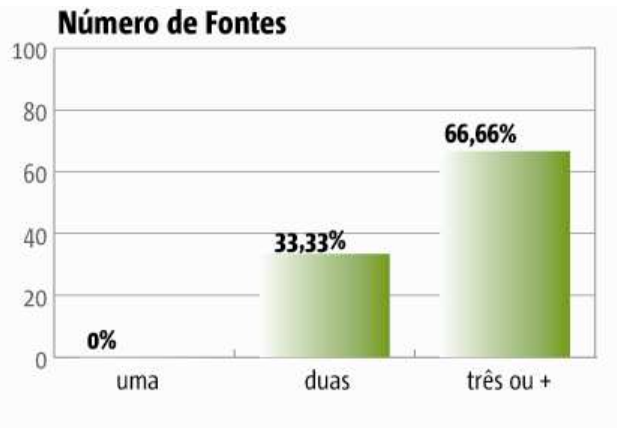

77 (b) Quantidade de fontes nas matérias.

a) Principais temas da amostra do noticiário do primeiro semestre de 1994

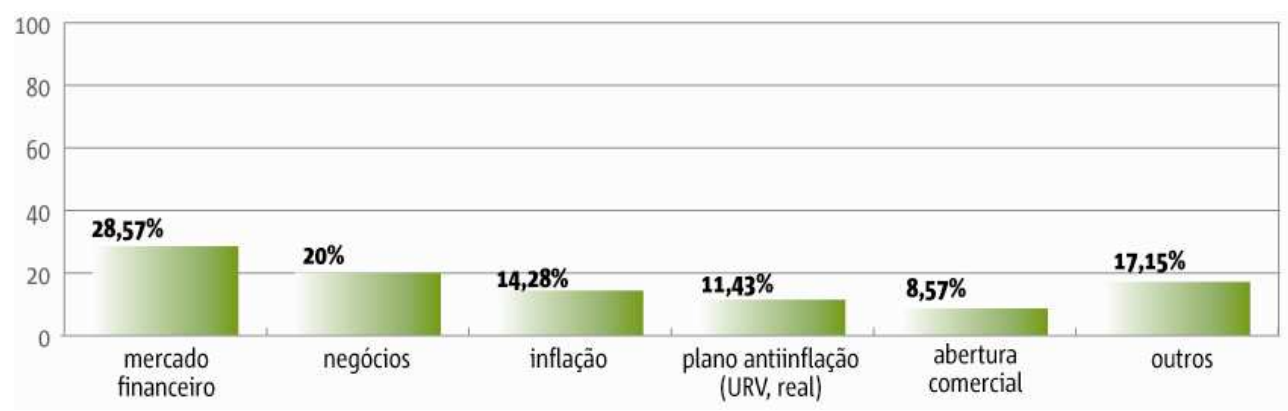

Figura 78. Temas de predomínio no noticiário, 1o. semestre de 1994.

b) Análise dos temas da amostragem do primeiro semestre de 1994

Notícias sobre mercado financeiro/1994

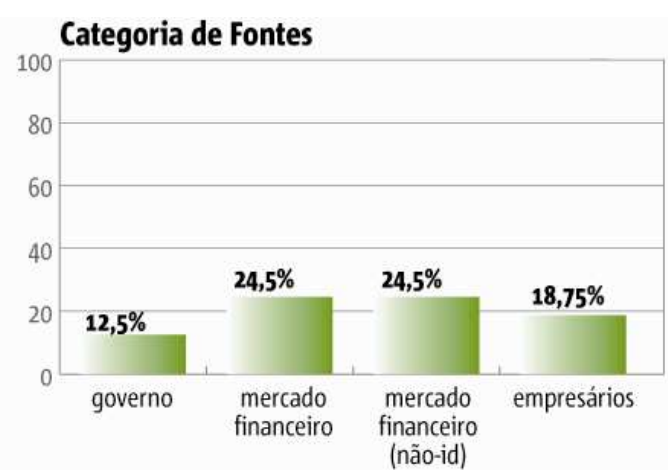

Figura 79. (a) Predominância por origem.

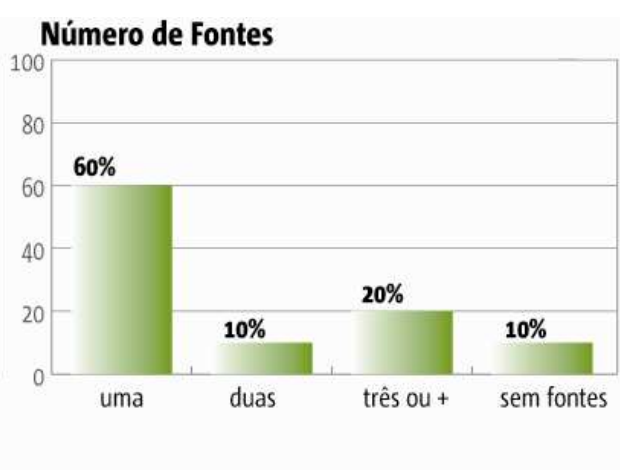

79 (b) Quantidade de fontes nas matérias. 
Notícias sobre negócios/1994

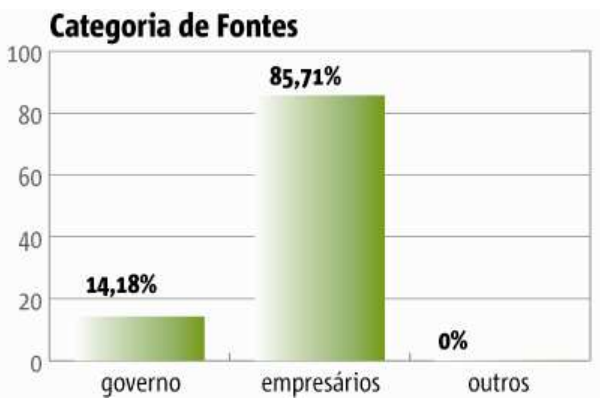

Figura 80. (a) Predominância por origem.

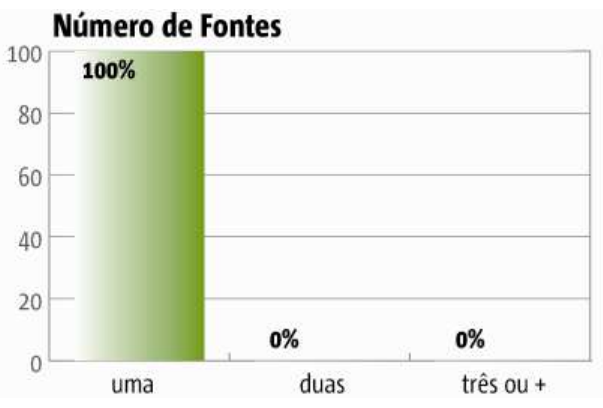

80 (b) Quantidade de fontes nas matérias.

Notícias sobre inflação/1994

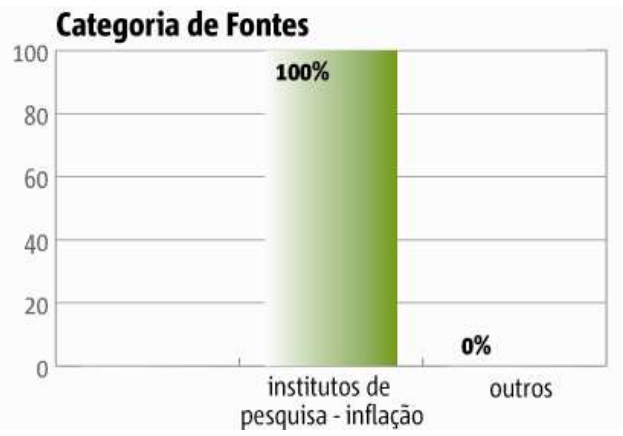

Figura 81. (a) Predominância por origem.

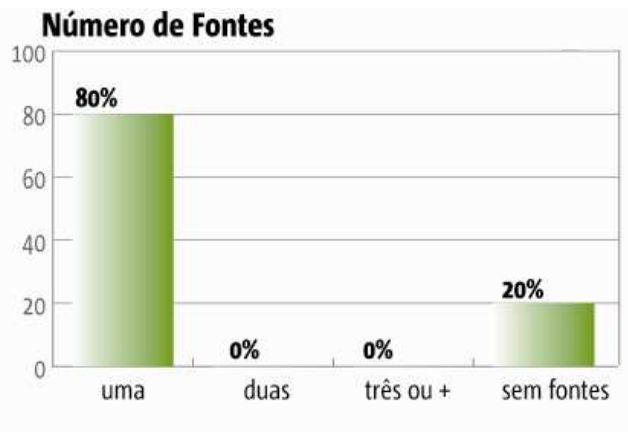

81 (b) Quantidade de fontes nas matérias.

Notícias sobre URV/Plano Real/ 1994

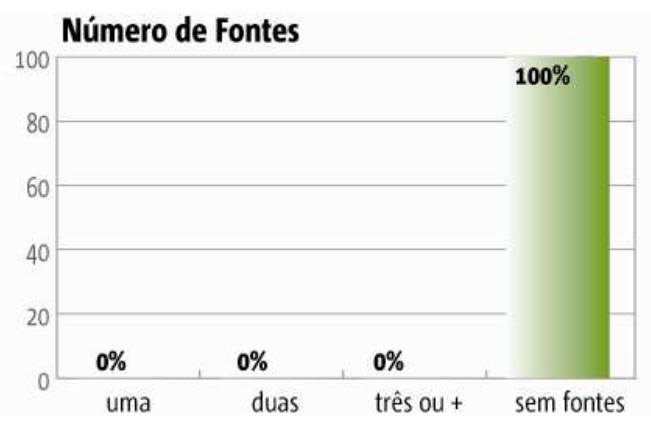

Figura 82. Quantidade de fontes nas matérias.

Como as matérias não tinham fontes, não foi possível categorizá-las 
Notícias sobre abertura comercial/1994

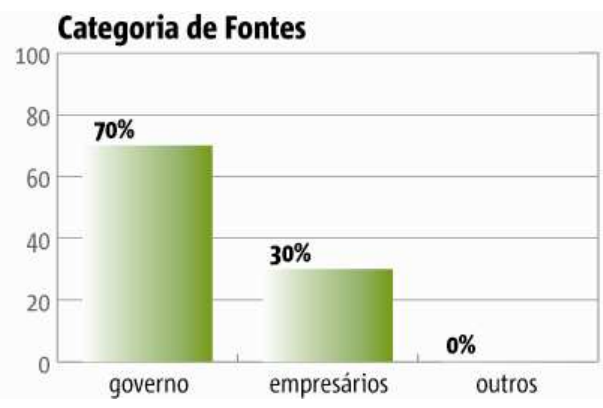

Figura 83. (a) Predominância por origem.

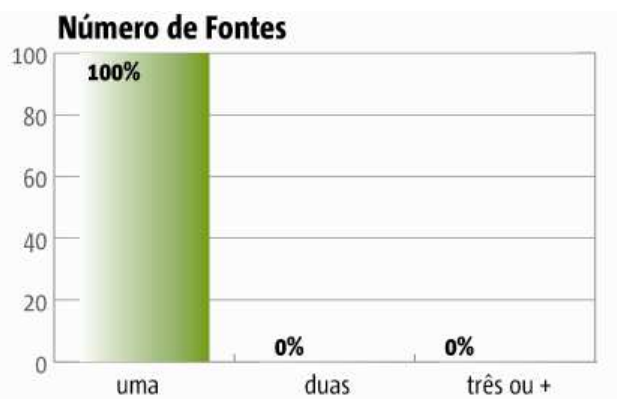

83 (b) Quantidade de fontes nas matérias.

a) Principais temas da amostra do noticiário do primeiro semestre de 1996

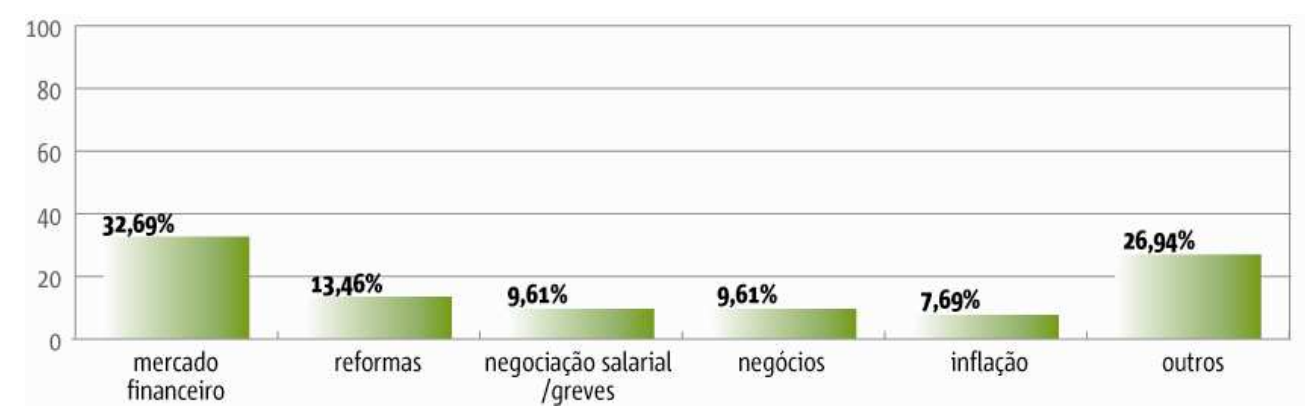

Figura 84. Temas de predomínio no noticiário, 1o. semestre de 1996.

b) Análise dos temas da amostragem do primeiro semestre de 1996

Notícias sobre mercado financeiro/1996

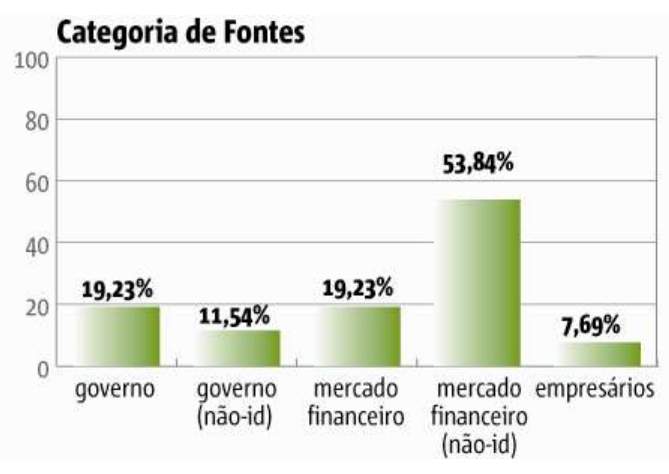

Figura 85. (a) Predominância por origem.

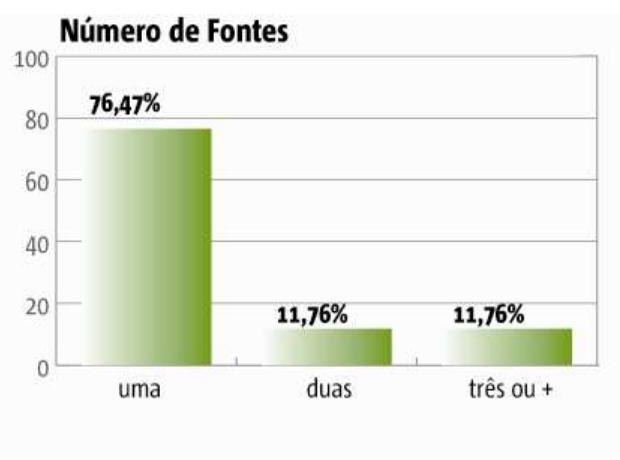

85 (b) Quantidade de fontes nas matérias. 
Notícias sobre reformas/1996

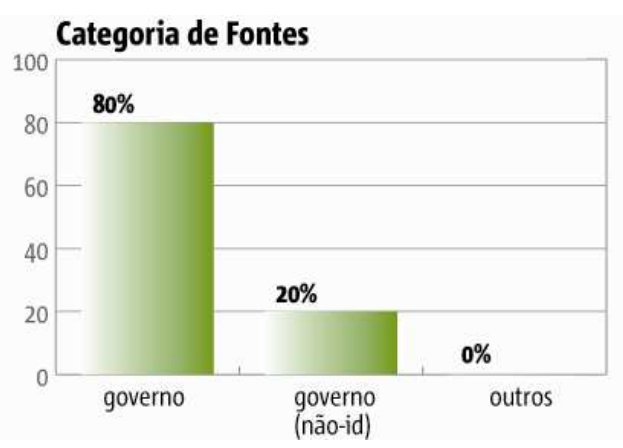

Figura 86. (a) Predominância por origem.

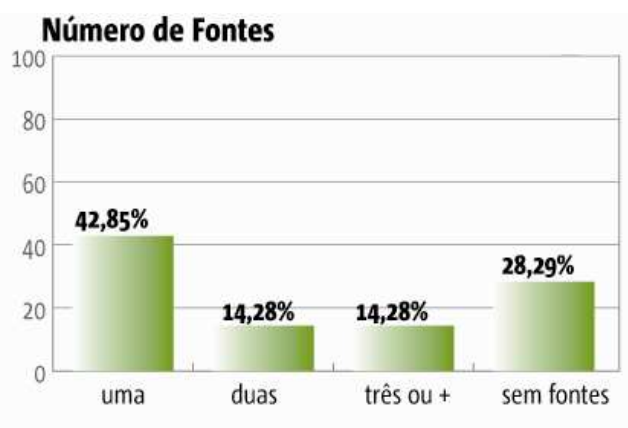

86 (b) Quantidade de fontes nas matérias.

Notícias sobre negociação salarial/1996

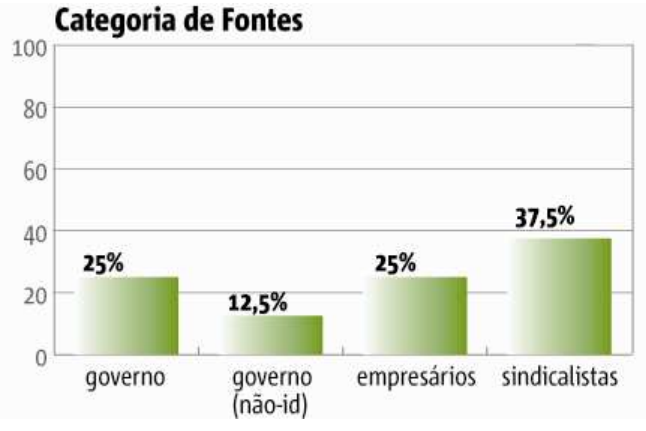

Figura 87. (a) Predominância por origem.

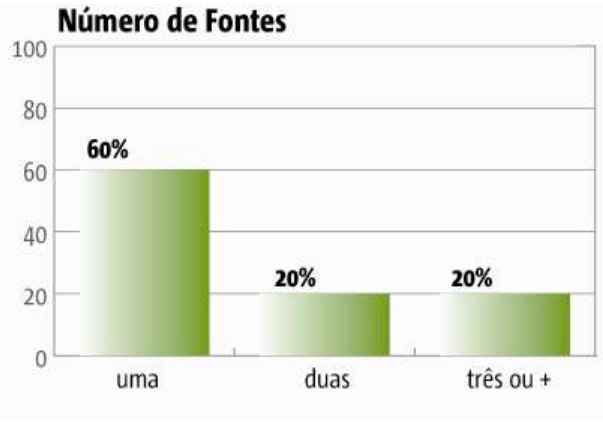

87 (b) Quantidade de fontes nas matérias.

Notícias sobre negócios/1996

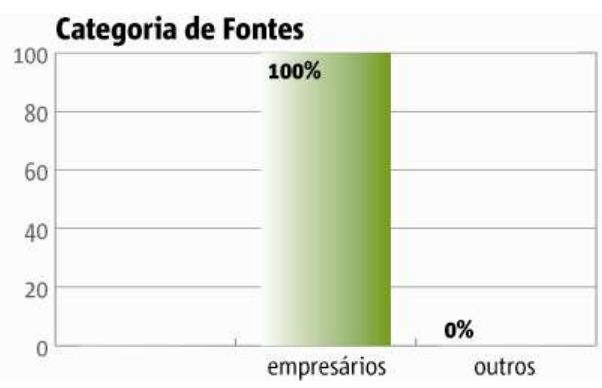

Figura 88. (a) Predominância por origem.

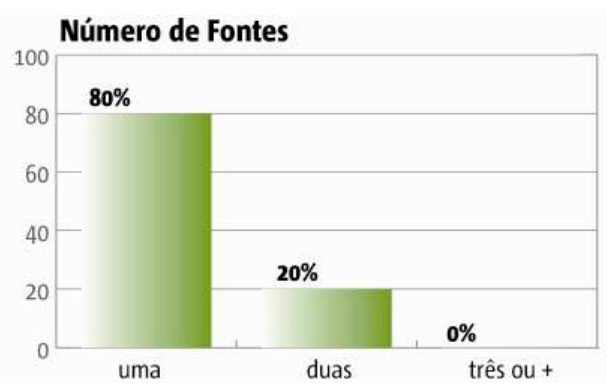

88 (b) Quantidade de fontes nas matérias. 
Notícias sobre inflação/1996
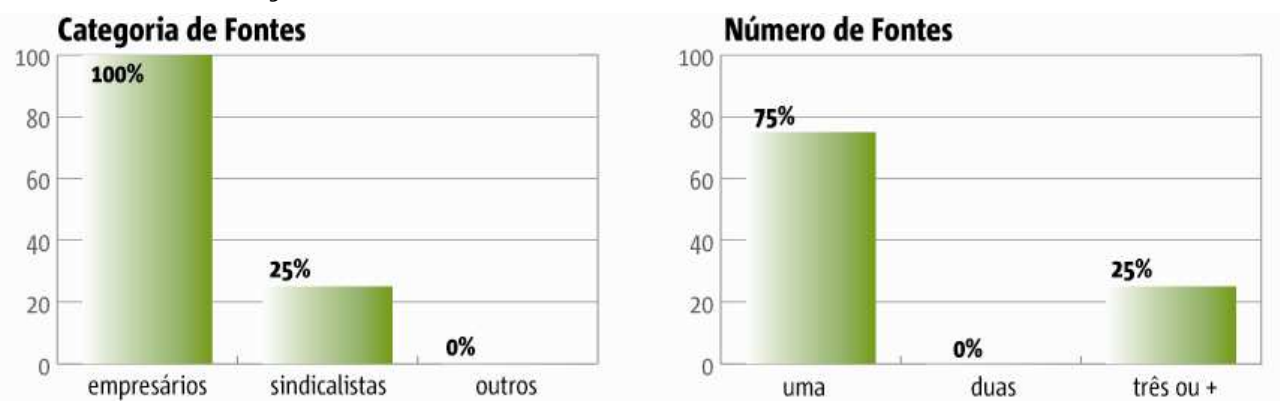

Figura 89. (a) Predominância por origem.

89 (b) Quantidade de fontes nas matérias.

a) Principais temas da amostra do noticiário do primeiro semestre de 1998

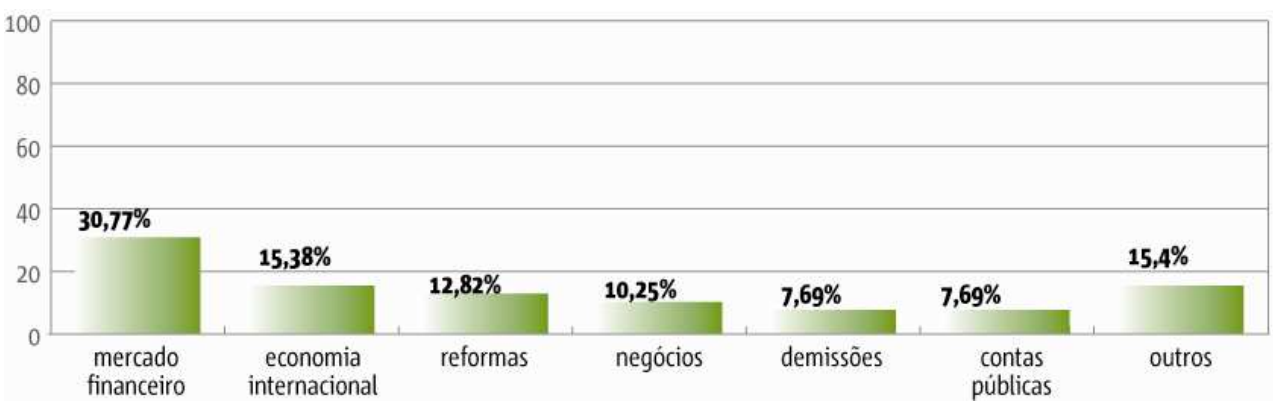

Figura 90. Temas de predomínio no noticiário, 1o. semestre de 1998.

b) Análise dos temas da amostragem do primeiro semestre de 1998

Notícias sobre mercado financeiro/1998

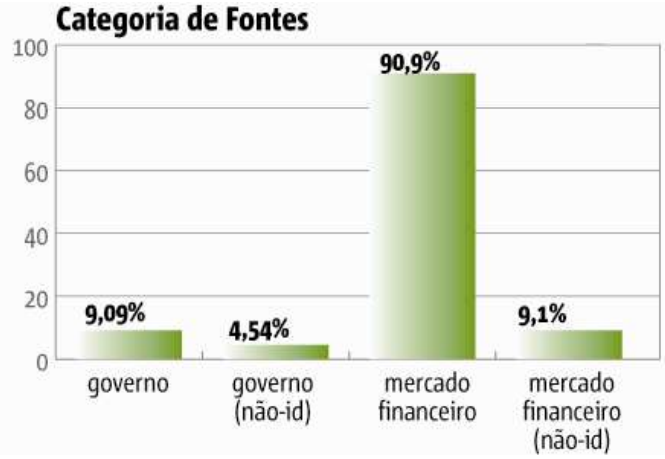

Figura 91. (a) Predominância por origem.

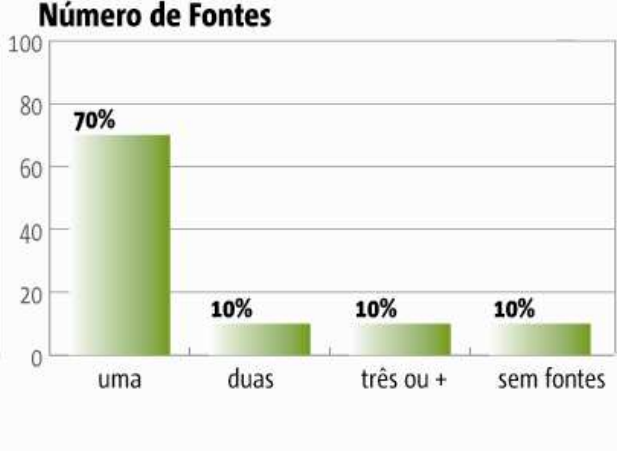

91 (b) Quantidade de fontes nas matérias. 
Notícias sobre economia internacional/1998

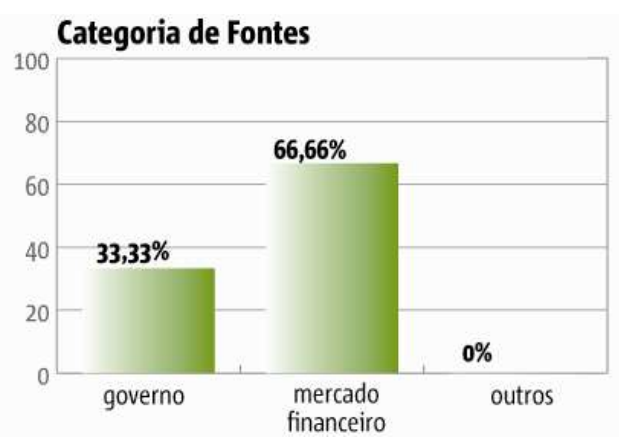

Figura 92. (a) Predominância por origem.

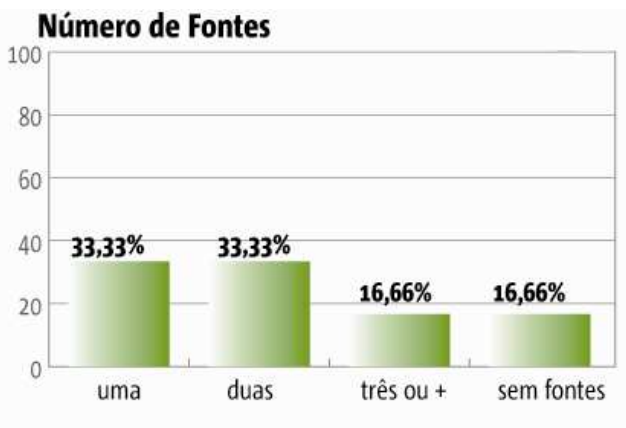

92 (b) Quantidade de fontes nas matérias.

Notícias sobre reformas/1998

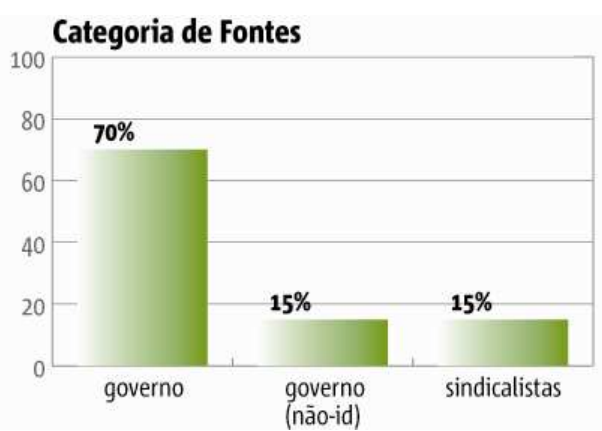

Figura 93. (a) Predominância por origem.

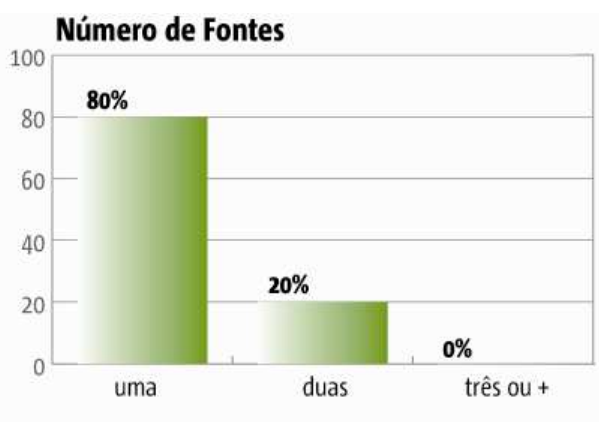

93 (b) Quantidade de fontes nas matérias. 
Notícias sobre negócios/1998

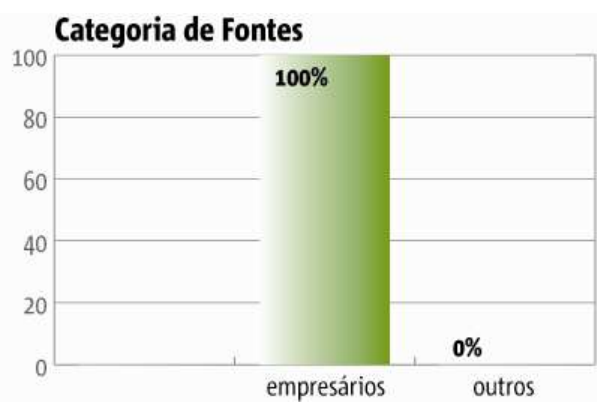

Figura 94. (a) Predominância por origem.

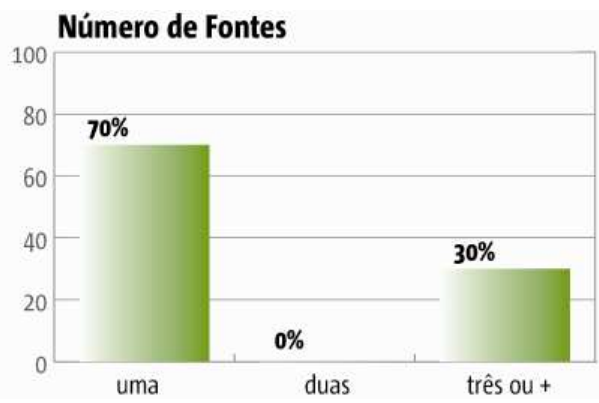

94 (b) Quantidade de fontes nas matérias.

Notícias sobre demissões/1998

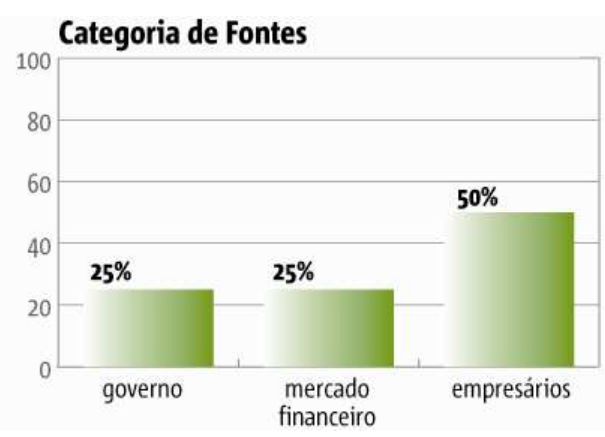

Figura 95. (a) Predominância por origem.

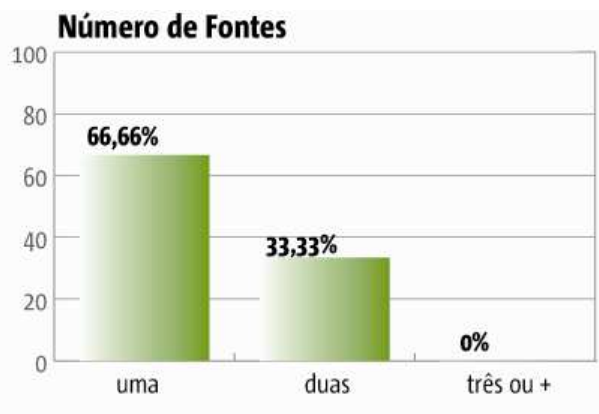

95 (b) Quantidade de fontes nas matérias.

Notícias sobre contas públicas/1998

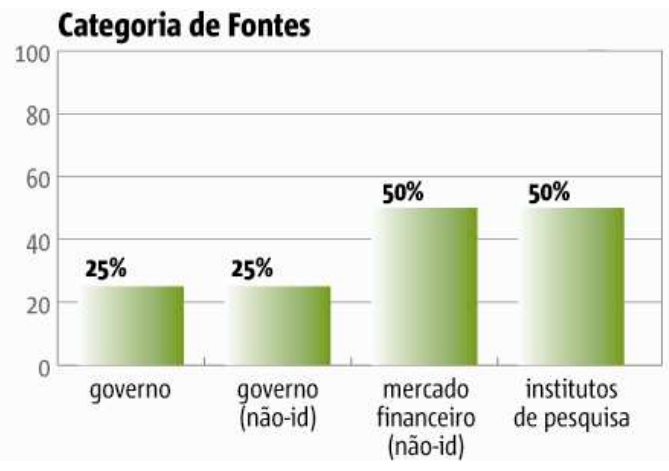

Figura 96. (a) Predominância por origem.

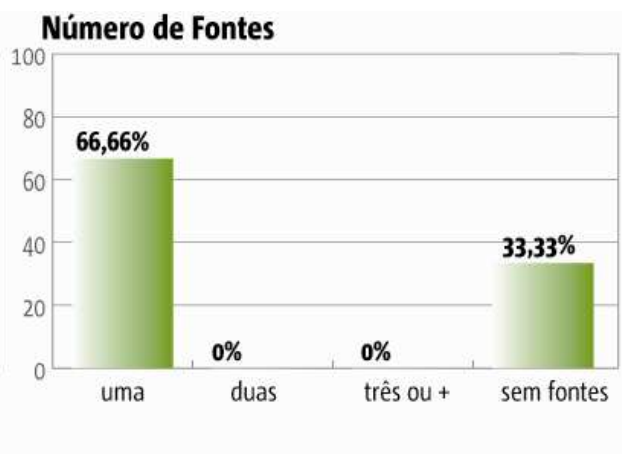

96 (b) Quantidade de fontes nas matérias. 
a) Principais temas da amostra do noticiário do primeiro semestre de 2000

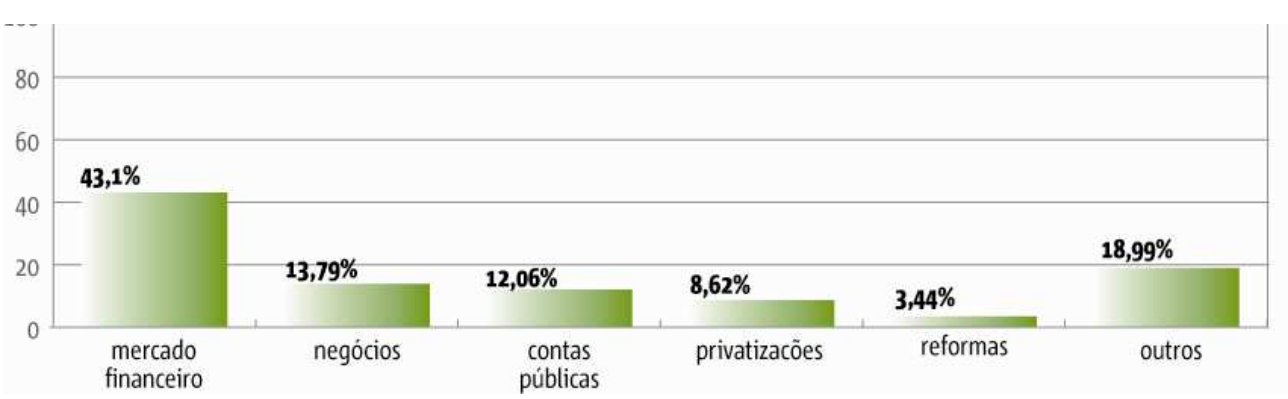

Figura 97. Temas de predomínio no noticiário, 10. semestre de 2000.

b) Análise dos temas da amostragem do primeiro semestre de 2000

Notícias sobre mercado financeiro/2000
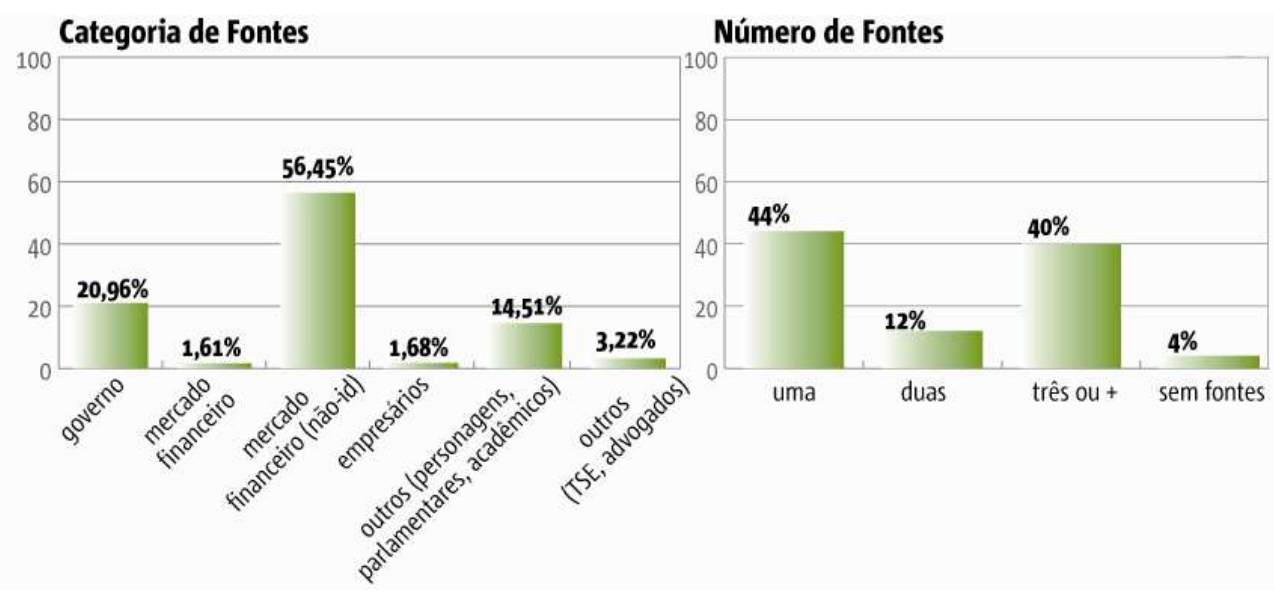

Figura 98. (a) Predominância por origem.

98 (b) Quantidade de fontes nas matérias. 
Notícias sobre negócios/2000

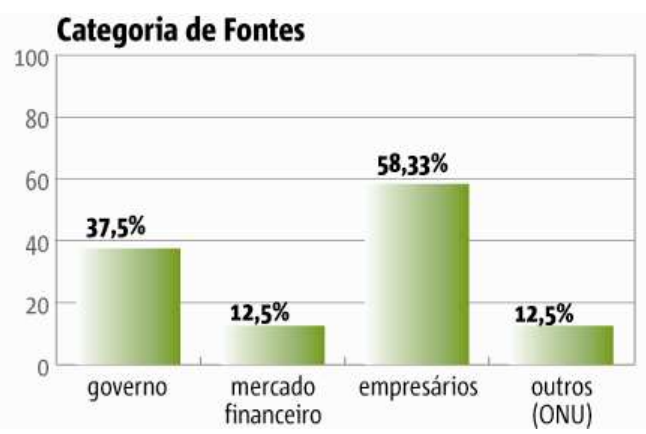

Figura 99. (a) Predominância por origem.

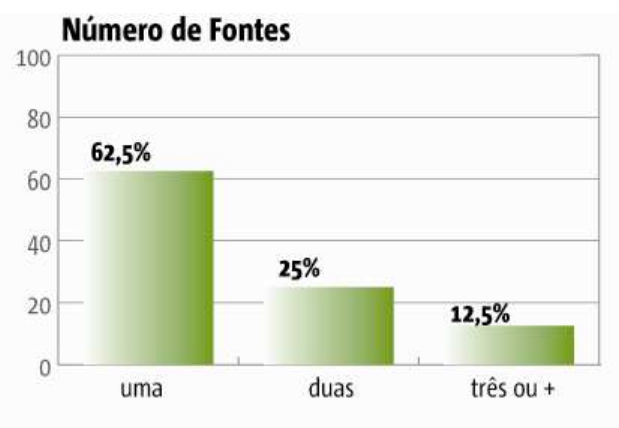

99 (b) Quantidade de fontes nas matérias.

Notícias sobre contas públicas/2000

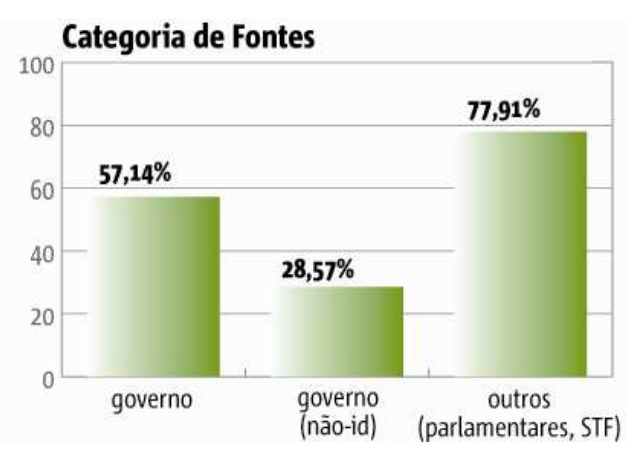

Figura 100. (a) Predominância por origem.

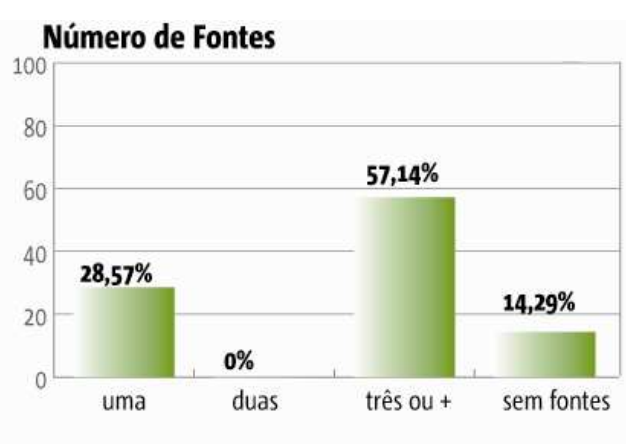

100 (b) Quantidade de fontes nas matérias.

Notícias sobre privatizações/2000

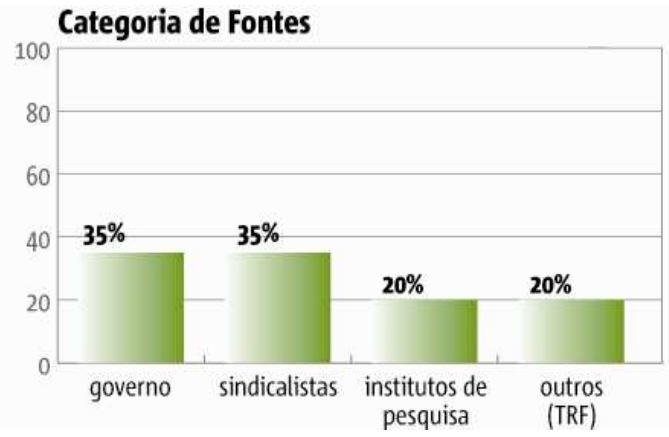

Figura 101. (a) Predominância por origem.

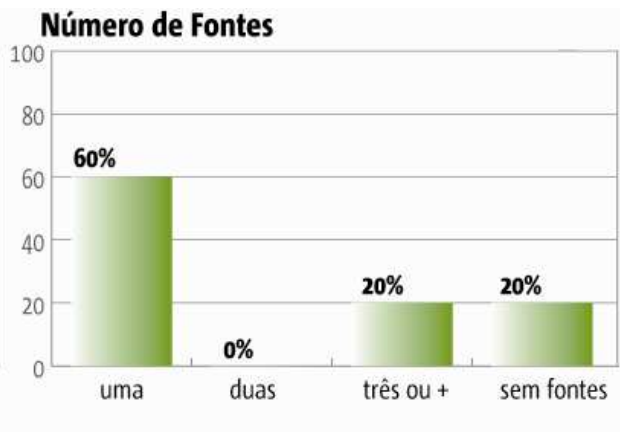

101 (b) Quantidade de fontes nas matérias. 
Notícias sobre reformas/2000
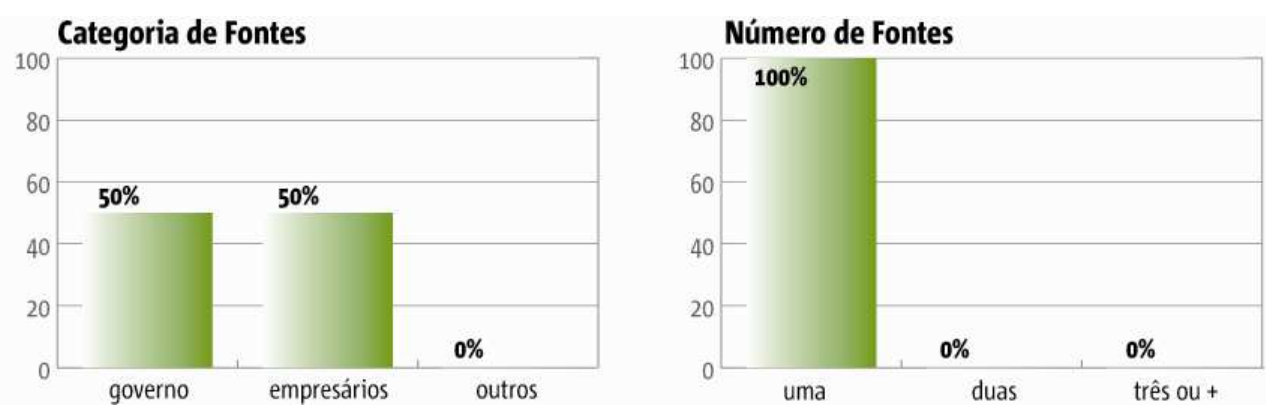

Figura 102. (a) Predominância por origem.

102 (b) Quantidade de fontes nas matérias.

a) Principais temas da amostra do noticiário do primeiro semestre de 2002

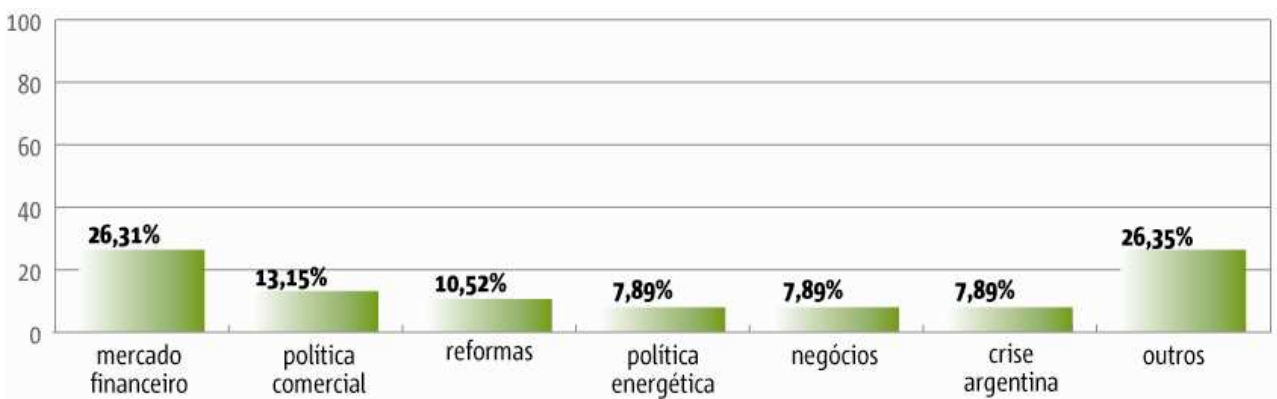

Figura 103. Temas de predomínio no noticiário, 1o. semestre de 2002.

b) Análise dos temas da amostragem do primeiro semestre de 2002

Notícias sobre mercado financeiro/2002

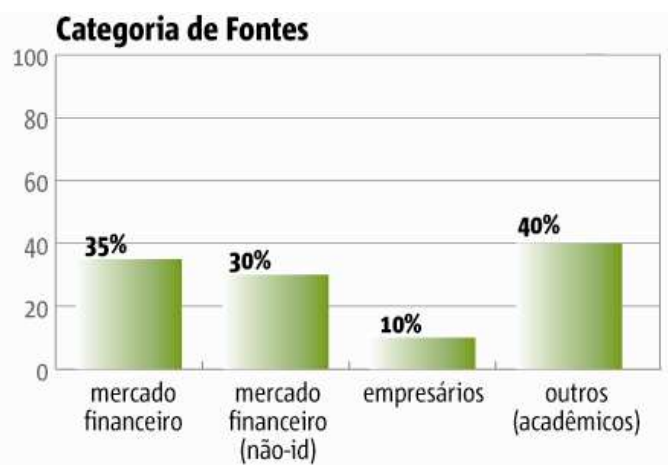

Figura 104. (a) Predominância por origem.

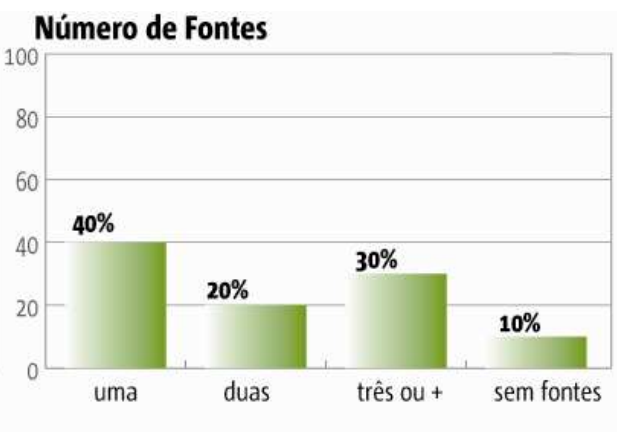

104 (b) Quantidade de fontes nas matérias. 
Notícias sobre política comercial/2002

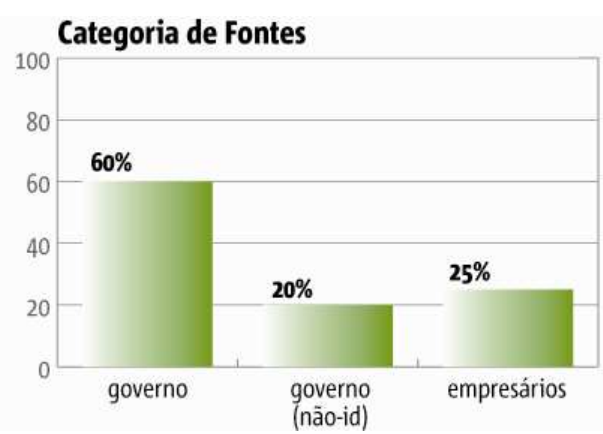

Figura 105. (a) Predominância por origem.

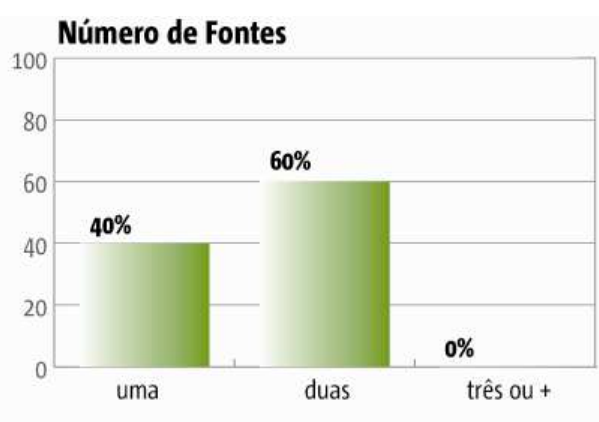

105 (b) Quantidade de fontes nas matérias.

Notícias sobre reformas/2002

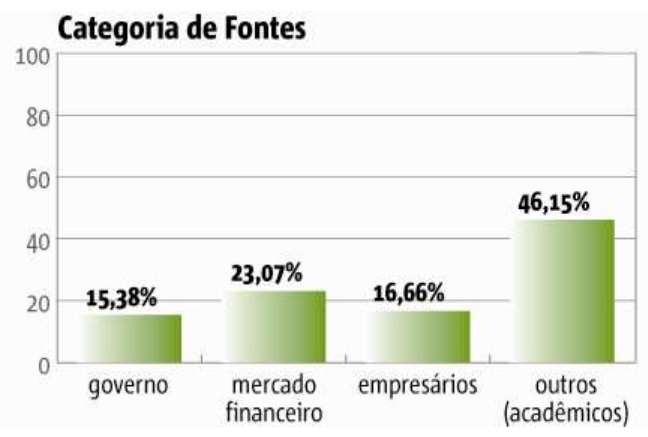

Figura 106. (a) Predominância por origem.

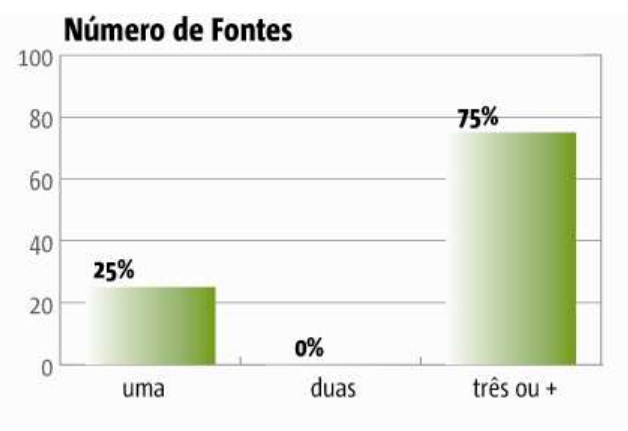

106 (b) Quantidade de fontes nas matérias.

Notícias sobre política energética/2002

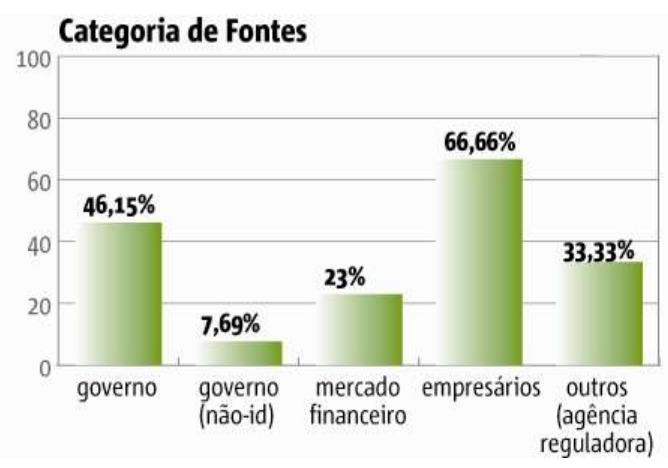

Figura 107. (a) Predominância por origem.

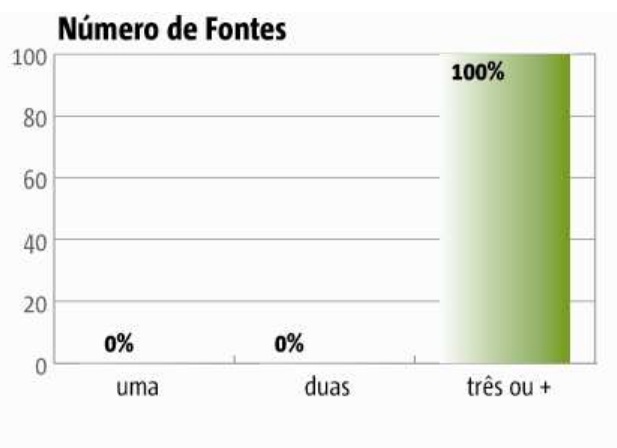

107 (b) Quantidade de fontes nas matérias. 
Notícias sobre negócios/2002

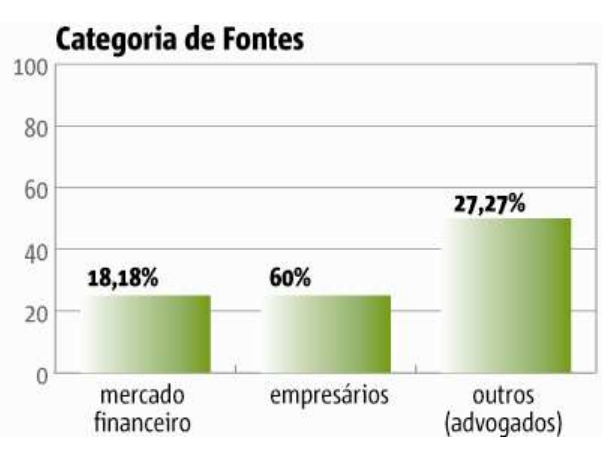

Figura 108. (a) Predominância por origem.

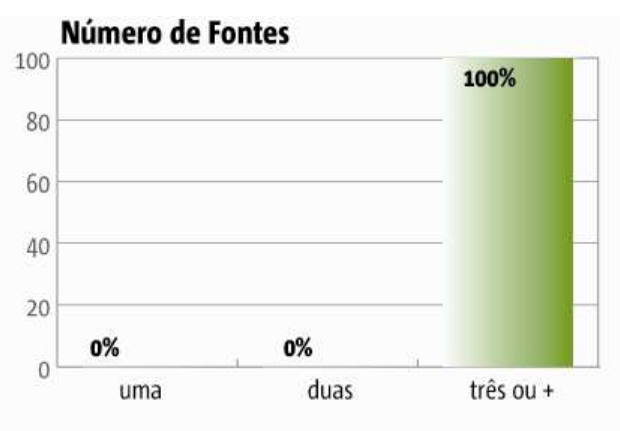

108 (b) Quantidade de fontes nas matérias.

Notícias sobre crise argentina/2002

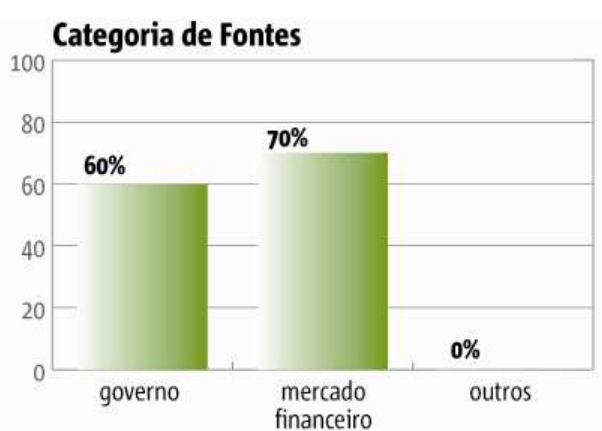

Figura109. (a) Predominância por origem.

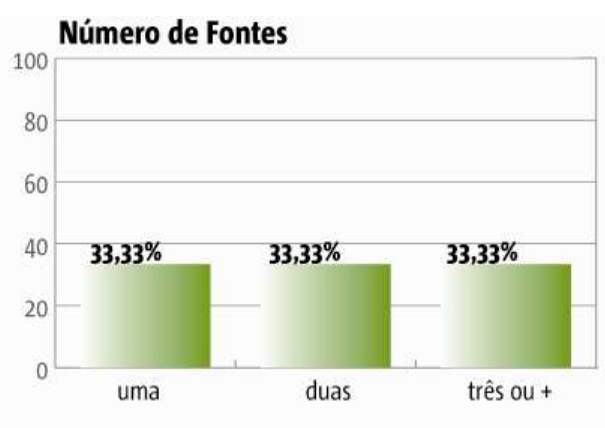

109 (b) Quantidade de fontes nas matérias.

\subsubsection{COMENTÁRIOS}

TEMAS: 
A amostra de 14 semestres mostrou que temas do mercado financeiro só não apareceram entre os cinco de maior prevalência nas matérias-manchetes em 1989. Naquele ano, o noticiário econômico foi dominado por greves e negociação salarial dos trabalhadores, inflação e preço dos combustíveis, além de lei de informática.

Nos outros 13 semestres, o mercado financeiro sempre esteve presente entre os temas de maior prevalência nas matérias de alto de página. Entendem-se como temas do mercado financeiro a) comportamento dos mercados de ações, câmbio e juros; b) quaisquer tipos de investimentos de pessoas físicas ou jurídicas realizados dentro do sistema financeiro; c) medidas do Banco Central que afetam o funcionamento do mercado de capitais, como compra ou venda de moedas estrangeiras, decisões sobre taxas de juros, cobrança de impostos sobre aplicações financeiras; além de questões ideológicas de todo poder ao mercado para o bem geral de todos, como d) privatizações; e) reformas tributária e do Estado; f) contas públicas e rigidez fiscal; g) abertura comercial, financeira e de serviços. Em 1991, 1994, 1996, 1998, 2000 e 2002, matérias sobre esses assuntos foram as que mais apareceram no noticiário. Em 1993, 1995 e 1999, ocuparam o segundo lugar entre os assuntos mais noticiados. Em 1990 e 1992, foram o terceiro tema mais presente.

No período pesquisado, o tema contas públicas apareceu pela primeira vez em 1992, como o quarto tema de maior prevalência no alto das páginas, atrás de negócios, inflação e mercado financeiro. Em 1996, reformas apareceram pela primeira vez, já como o segundo de maior predomínio, atrás apenas de mercado financeiro. Em 1997, assuntos ligados às privatizações dominaram o noticiário, seguidos por contas públicas, inflação, negócios e economia internacional. Em 1998, reformas apareceram em terceiro lugar, enquanto contas 
públicas foram o quinto assunto de maior prevalência. Em 1999, contas públicas apareceram em terceiro lugar. Já no ano 2000, o noticiário foi tomado por assuntos do mercado financeiro ou de interesse desse setor. Somados aos assuntos de bolsas e mercados de câmbio e juros, apareceram contas públicas, privatizações e reformas. Já no primeiro semestre de 2001, os jornais se concentraram em temas de abertura comercial e do racionamento de energia, com um pouco de economia internacional e de privatizações, voltando a tocar de forma mais consistente no assunto reformas em 2002.

Em resumo, de 1989 a 1994, as oscilações do mercado financeiro dividiam a predominância no noticiário com inflação, greves e negociações salariais. Depois disso, somaram-se aos temas de bolsas, dólar e juros os assuntos de reformas, privatizações e contas públicas.

Duas constatações chamaram especial atenção na análise de temas foi o contraste entre a presença constante de assuntos como câmbio, juros, bolsa de valores, reformas, privatizações, impostos, gastos públicos, arrecadação, superávits, déficits, que sucederam ao tema inflação, e a ausência de assuntos que bem poderiam entrar no noticiário econômico, como investimentos em saneamento básico, infraestrutura, transportes públicos, saúde e habitação. Esses temas não apareceram uma única vez na amostragem das matérias de alto de página.

\section{NÚMERO E CATEGORIAS DE FONTES:}


O objetivo de se mapear o número de fontes foi avaliar a pluralidade do noticiário. Já a categorização das fontes de acordo com sua procedência ajudou a traçar um quadro sobre a predominância de algum grupo dentro do noticiário. O cruzamento entre as pesquisas de número e de categorização de fontes reforçou a percepção sobre a financeirização das notícias. No comentário abaixo, analisamos o número e procedência/categorias de fontes, começando pelas matérias menos plurais.

a) Matérias sem fontes: de todas as matérias analisadas, as menos plurais (e menos transparentes) foram as referentes ao Plano Real de 1994. Na amostra, todas as matérias que apareceram sobre o tema não trouxeram fonte, nem sequer "fontes próximas ao tema" ou "assessores" não-identificados. Nada. A ausência de fontes revela uma prática bastante comum no jornalismo, que é o "off-the-record" total ou parcial. No caso do Plano Real, as autoridades forneciam aos jornalistas, na condição de anonimato, pedaços do que viria a ser a nova política econômica, com o intuito de testar a reação de diferentes lados da opinião pública a determinada proposta. O jornalista, em troca, conseguia o "furo" de reportagem, jargão jornalístico para matéria exclusiva.

Exceto por esse episódio, não houve qualquer outro período em que as matérias sem fontes predominaram sobre as outras. Embora não tenham prevalecido, houve matérias sem fontes também nas seguintes situações: em 1990, em notícias sobre inflação e mercado financeiro; em 1992 em reportagens sobre inflação e contas públicas; também em 1994, mas em assuntos do mercado financeiro; em 1995, mercado financeiro; em 1996, reformas; em 1998, mercado financeiro, contas 
públicas e economia internacional; em 1999, mercado e economia internacional; no ano 2000, mercado financeiro, contas públicas e privatizações; e em 2002, nas matérias do mercado financeiro.

b) Matérias com apenas uma fonte: em 1991, todas as matérias sobre privatização só trouxeram uma fonte: ou funcionários do governo não-identificados ou acadêmicos. Em 1994, foram as matérias de negócios que trouxeram ou uma fonte empresarial ou uma fonte do governo. No mesmo ano, aparecem também as reportagens de abertura comercial, ou com fonte do governo ou exportadores. Em 1999, foram as matérias de contas públicas, cujas fontes foram igualmente divididas em governo e governo não-identificado. No ano 2000, as matérias de reformas trouxeram ou uma fonte do governo ou uma fonte do mundo empresarial. Em 2001, as matérias de negócios analisadas só trouxeram uma fonte cada, todas empresariais. No mesmo ano, as reportagens sobre privatizações novamente só trouxeram uma fonte, divididas nas categorias governo, governo não-identificado e mercado financeiro.

$\mathrm{Na}$ amostragem de 14 semestres, apareceram 72 temas (incluindo as repetições). Foram cinco a cada semestre, sendo que duas vezes o percentual de aparição foi igual para dois assuntos. Do total, em 36 predominaram matérias com uma única fonte. A prevalência de matérias com uma fonte aconteceu nos temas negócios, mercado financeiro e economia internacional, com fontes provenientes do setor empresarial no primeiro caso, e de bancos e instituições financeiras no segundo e terceiro casos. Das 16 vezes em que aparecem os temas privatizações, reformas, abertura comercial e contas públicas, houve predomínio de matérias com uma fonte, 
sendo que todas vieram do governo (ainda que a fonte não fosse identificada). Nas matérias em que houve mais de uma fonte, o governo dividiu espaço primeiramente com o mercado financeiro e em seguida com os empresários. Os sindicalistas aparecerem citados apenas em duas aparições temáticas (uma vez em reformas e outra em privatizações).

Mesmo no tema inflação, que esteve presente em oito das 72 aparições temáticas, parte considerável das matérias teve apenas uma fonte, com predominância de institutos de pesquisas.

c) Apesar do predomínio das matérias com uma fonte, houve matérias com três fontes ou mais. Em 1991, todas as matérias sobre salários trouxeram mais de uma fonte, sendo empresários, governo e sindicalistas. O mesmo ocorreu em 2002, quando nas matérias sobre política energética apareceram governo, mercado financeiro, acadêmicos e institutos de pesquisa, e nas matérias de negócios foram citados empresários e outros. Também se viu que quando houve predominância de três ou mais fontes, isso aconteceu principalmente nas matérias de negócios, com predomínio de depoimentos de vários empresários, seguido por membros do governo. Em 1989, as matérias com três fontes predominaram sobre as demais nos assuntos greves, negociação salarial e combustíveis. No caso de greves, as fontes vieram de governo, empresários e sindicatos; em negociação salarial, a procedência foi igual a greves. No caso dos combustíveis, as fontes vieram do governo e do setor empresarial. 
d) Matérias com duas fontes prevaleceram sobre outras nas seguintes ocasiões: em 1990, nas matérias de greves, com fontes provenientes de governo, setor empresarial e sindicatos; em 1991, nos temas mercado financeiro (com predominância de fontes do mercado financeiro e, em menor escala, do governo), e inflação (com fontes de governo, institutos de pesquisas e do setor empresarial); 1993, em inflação (empresários, mercado financeiro e institutos de pesquisas), mercado financeiro (com fontes apenas do próprio setor), e negócios (fontes empresariais); e em 1997, nas matérias de economia internacional (fontes de governos e mercado financeiro).

O levantamento mostrou que o governo predominou como fonte de matérias em todo o período analisado, seguido por mercado financeiro e empresários - estes últimos com foco no interesse de seus acionistas.

O que mais chamou a atenção - algo que na verdade surpreendeu - foi fato de o próprio governo brasileiro ter se tornado o grande porta-voz e agente dos interesses do capital financeiro. Foram as autoridades que introduziram e defenderam no noticiário assuntos como reformas (Previdência, do funcionalismo, tributária, trabalhista, sindical), abertura para a entrada de capitais externos, privatizações e enxugamento das contas públicas, justificando que apenas a adoção desse receituário levaria o País ao desenvolvimento sustentado. O governo assumiu como sua a agenda do neoliberalismo-financeiro. Refletindo as condições dos planos de combate à inflação, a predominância no noticiário diário passou a ser de medidas do Banco Central e do Ministério da Fazenda, além das propostas do Executivo para a reforma do Estado e do sistema tributário. 
A análise das matérias-manchetes mostrou que, além do governo, o Fundo Monetário Internacional (FMI), o Banco Mundial (Bird), Banco de Compensações Internacionais (BIS) e Instituto de Finanças Internacionais (IIF, na sigla em inglês), órgão que representa os grandes bancos mundiais, também tiveram amplo espaço para defender suas propostas.

Nos abres-de-páginas, os economistas de bancos apareceram cobrando reformas do governo, mas em escala muito menor do que as instituições multilaterais. O primeiro exemplo captado pela pesquisa, porém, apareceu no primeiro semestre de 1996, quando pela primeira vez uma matéria-manchete trouxe a crítica dos grandes bancos estrangeiros à suposta lentidão das reformas por conta da resistência do Congresso brasileiro em votá-las. A matéria chamou esses economistas de "a nata de brasilianistas da City e de Wall Street", referindo aos bairros financeiros de Londres e de Nova York. 

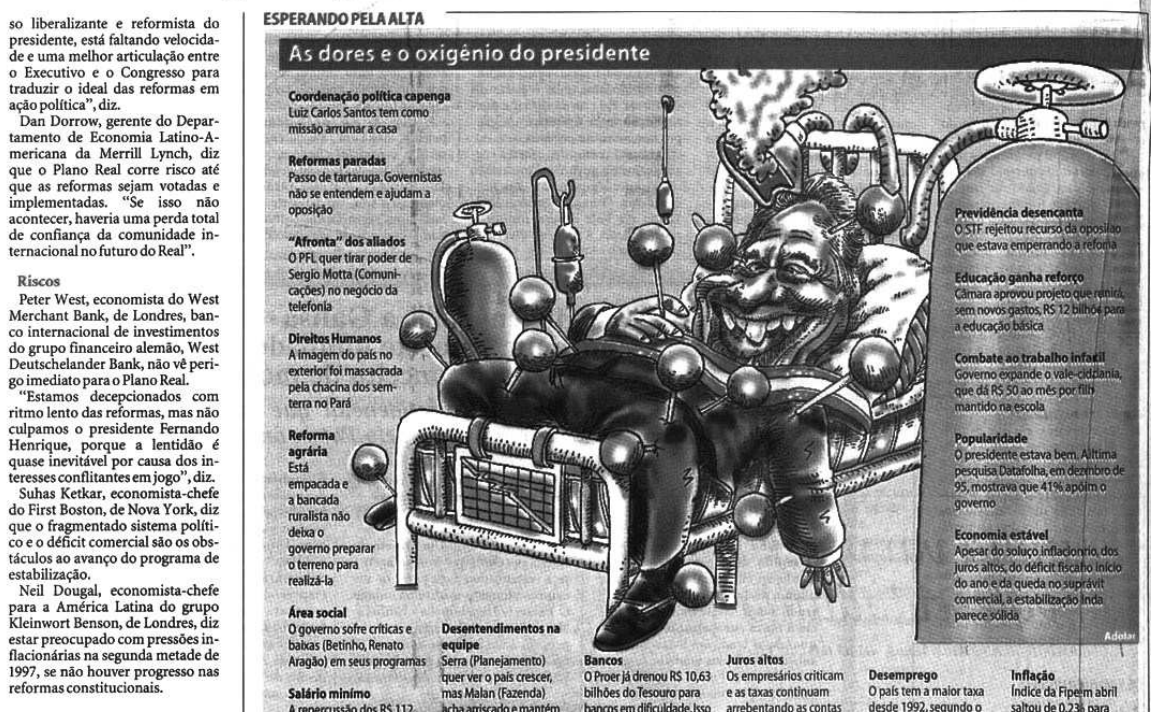

Figura 110. Matéria traz "a nata" do mercado financeiro internacional criticando o País (FSP, 10/5/1996). Reprodução fotográfica pelo Acervo do Estado de São Paulo.

\section{TRANSPARÊNCIA DAS FONTES:}

Em teoria, o maior grau de transparência se dá quando a fonte da reportagem é bem identificada, com nome, cargo e instituição em que trabalha. A identificação confere credibilidade à matéria, pois ajuda a revelar o jogo de forças político-ideológicas que domina o debate midiático, conferindo transparência ao noticiário.

Entre as fontes que mais predominaram nas matérias-manchetes - governo, mercado financeiro, empresários, sindicalistas e institutos de pesquisa de inflação - o governo foi o menos transparente. Cerca de $10 \%$ dos assuntos que vieram a público tendo o governo como fonte não tiveram qualquer identificação, enquanto em outros $20 \%$ houve fontes 
não-identificadas, como "assessores" e "fontes próximas".

Nas matérias relacionadas a mercado financeiro, 25\% não identificaram fontes. Já as matérias mais transparentes foram as que tiveram os sindicalistas como fonte, sempre bem identificados. Também nas matérias de negócios da amostra foi raro encontrar matérias de baixa transparência. 


\section{CAPÍTULO 5}

\section{A FINANCEIRIZAÇÃO DO JORNALISMO ECONÔMICO NO BRASIL - 3 \\ PESQUISAS - 2}

Os levantamentos quantitativos forneceram parte de um quadro que só se completaria com a realização de entrevistas. Em Pesquisas - 1, quantificaram-se fontes, temas, predominância no noticiário e transparência. Nesta parte do trabalho, os depoimentos com personagens da financeirização estabeleceram a relação entre o os dados obtidos e o comportamento das organizações. Foram realizados dois tipos de entrevistas. As dirigidas, apresentadas neste capítulo, e as abertas, no seguinte. Só com as entrevistas o estudo conseguiu alcançar o sentido social que o levantamento quantitativo sozinho não conseguiu.

\subsection{ENTREVISTAS DIRIGIDAS}

As entrevistas dirigidas foram realizadas com pauta pré-determinada e fechada, por telefone, com analistas econômicos. A amostra foi formada por 34 de um total das 50 
maiores instituições entre bancos e consultorias que em $2004^{55}$ fizeram parte da pesquisa Focus do Banco Central do Brasil, já citada na página 106. A Focus é um dos principais laços entre o Banco Central e o mercado financeiro e é onde se revela mais claramente a influência do mercado no noticiário. Além da pesquisa semanal, diretores do BC se reúnem trimestralmente com economistas das instituições que participam da Focus, geralmente na última semana do mês que antecede o da divulgação do Relatório Trimestral de Inflação (RTI). As reuniões costumam acontecer no final de fevereiro, maio, agosto e novembro e ocorrem no prédio do BC no Rio e em São Paulo. Às vezes, é primeiro em uma cidade, às vezes em outra, mas pelo menos três encontros acontecem na capital paulista, enquanto apenas um é no Rio. O objetivo oficial é dar elementos para o Banco Central confeccionar o RTI, conhecendo o que os analistas estão pensando sobre conjuntura. O encontro é dividido em economia internacional, inflação e atividade econômica nacional ${ }^{56}$.

Escolhidas as instituições (Focus) a serem entrevistadas nesta parte do trabalho e justificada a sua importância, a etapa seguinte foi definir as perguntas a serem feitas aos entrevistados. O objetivo desta pesquisa foi verificar quais instituições tinham departamentos de economia, quando esses departamentos foram criados, quais instituições tinham assessorias de imprensa e quais delas ofereciam treinamento para falar com os jornalistas ("media

\footnotetext{
${ }^{55}$ Ano em que foi realizado o levantamento, já como parte do projeto de pesquisa que originou este trabalho.

${ }^{56}$ Outro laço ainda mais forte da autoridade monetária com o mercado financeiro seria a reunião secreta que os diretores do Banco Central têm com alguns economistas selecionados, para saber o que eles pensam sobre a economia brasileira. Ficou conhecido como grupo de Fátima, em alusão ao terceiro segredo. Desde que a repórter da Folha Sheila D'Amorim, setorista do BC em Brasília, trouxe o caso à tona, as reuniões supostamente acabaram. Há boatos, no entanto, de que já teriam sido retomadas. Um dos organizadores desses encontros foi entrevistado para este trabalho, mas só aceitou falar na condição de anonimato e sem entrevista gravada. Essas reuniões não são divulgadas para a imprensa, não acontecem sempre no mesmo lugar (às vezes em Brasília, às vezes no Rio de Janeiro e às vezes em São Paulo) e seus participantes são orientados pela autoridade monetária a não divulgar o teor das conversas aos jornalistas que eventualmente venham a procurá-los.
} 
training"), todas ações comunicacionais que denotam interesse de inserção na imprensa. Considerando-se o que já foi desenvolvido no Capítulo 2 sobre o papel das assessorias de imprensa e dos departamentos de economia na relação com os jornalistas, passa-se agora ao detalhamento da entrevista dirigida.

As instituições ouvidas foram:

Unibanco

Deutsche Bank

Banco Santander

Ático Asset Management

Hedging-Griffo

Mellon Global Investment

Convenção Corretora

Fator Corretora

MB Associados

Global Station

GRC Visão

Global Invest

Concórdia Corretora

Banco Votorantin

MCM

Tendências Consultoria

Banco Cruzeiro do Sul

West LB

BNP Paribas 
Banco Fibra

Banco Safra

JP Morgan

Planner Corretora

Gap Asset Management Recomendações

Banco Espírito Santo

ABN Real

Banco Schahin

Banco Pátria

Nossa Caixa

Citibank

Banco Rendimento

Itaú

Bradesco

Bic Banco

As perguntas feitas foram:

-A sua instituição tem departamento econômico?

-Se sim, desde quando?

-Qual a função do departamento de economia?

-O material produzido pelo departamento de economia é enviado a jornalistas?

-O banco em que o senhor (a) trabalha tem assessoria de imprensa?

-Desde quando?

-Como atua a assessoria de imprensa em relação a seu trabalho? 
-O senhor (a) recebeu treinamento para falar com a imprensa?

-Qual a sua formação profissional?

\subsubsection{TABULAÇÃO DOS RESULTADOS - ENTREVISTAS DIRIGIDAS}

-Sua instituição tem departamento econômico?

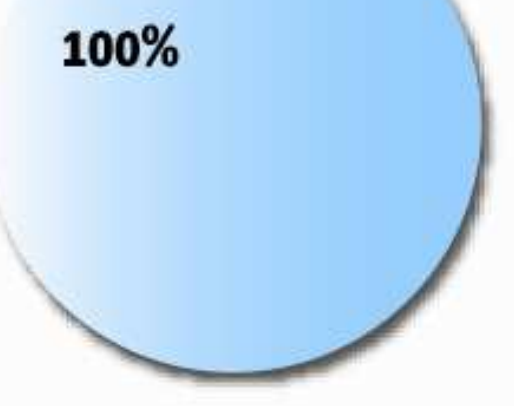

Sim

1 Não

Figura 111. Total de instituições com departamentos econômicos. 
-Se sim, desde quando?

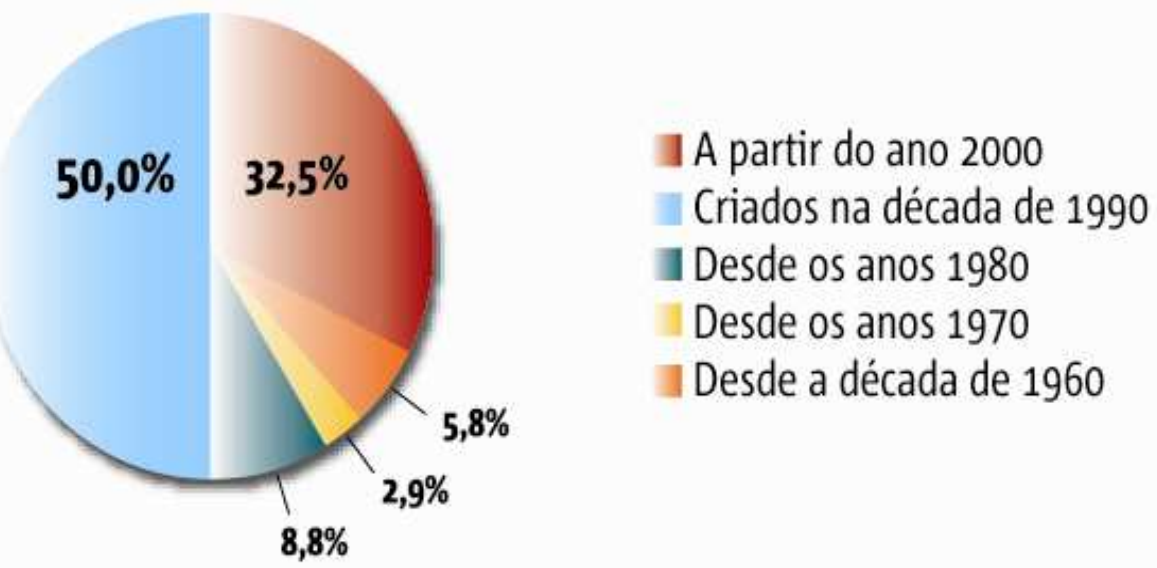

Figura 112. Início dos departamentos econômicos.

-Qual a função do departamento de economia?

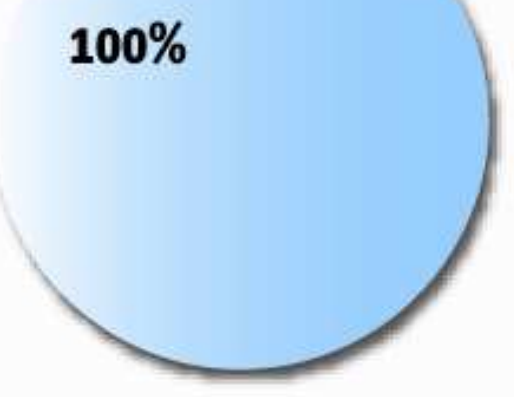

Realização de pesquisas e relatórios

1 Outras funções

Figura 113. Funções dos departamentos econômicos. 
-O material produzido pelo departamento de economia de sua instituição é enviado a jornalistas?

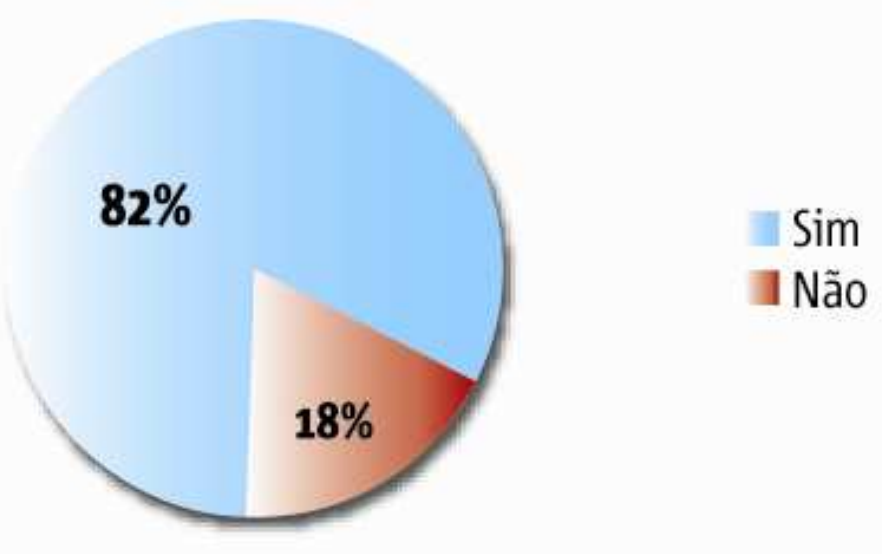

Figura 114. No. de instituições que enviam material de departamentos econômicos para jornalistas.

-A instituição em que o senhor (a) trabalha tem assessoria de imprensa?

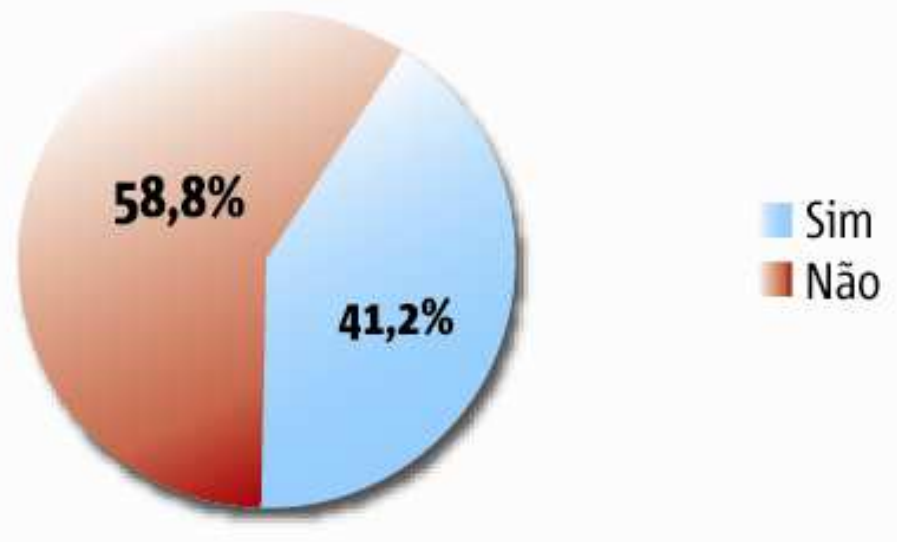

Figura 115. Instituições que têm assessoria de imprensa. 
-Como atua a assessoria de imprensa em relação a seu trabalho?

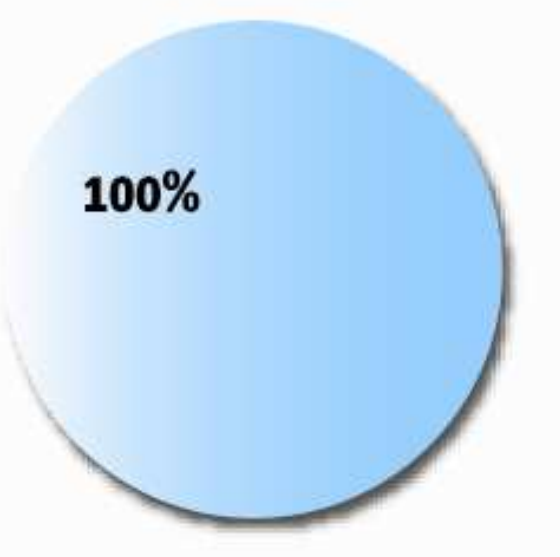

\section{Media-training e contato com jornalistas}

Figura 116. Papel das assessorias de imprensa.

-O senhor (a) recebeu treinamento para falar com a imprensa?

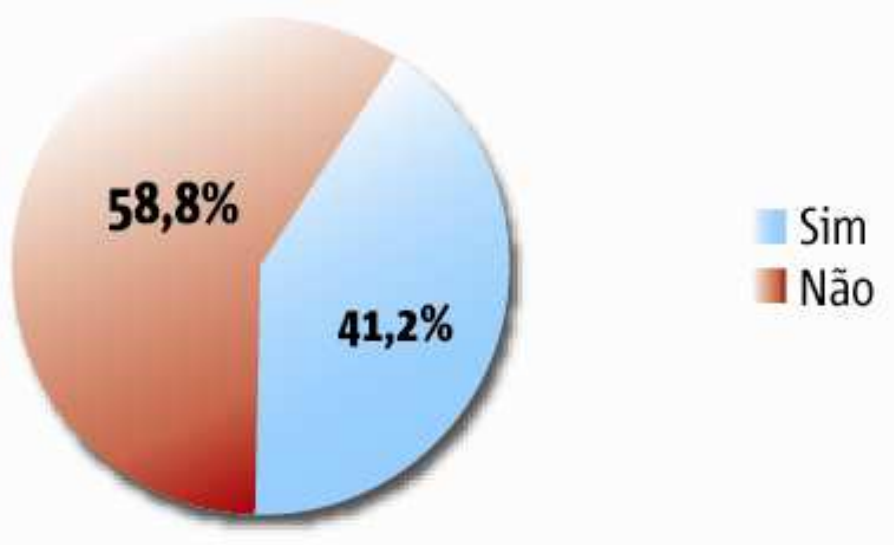

Figura 117. Quantos receberam treinamento para falar com a imprensa. 


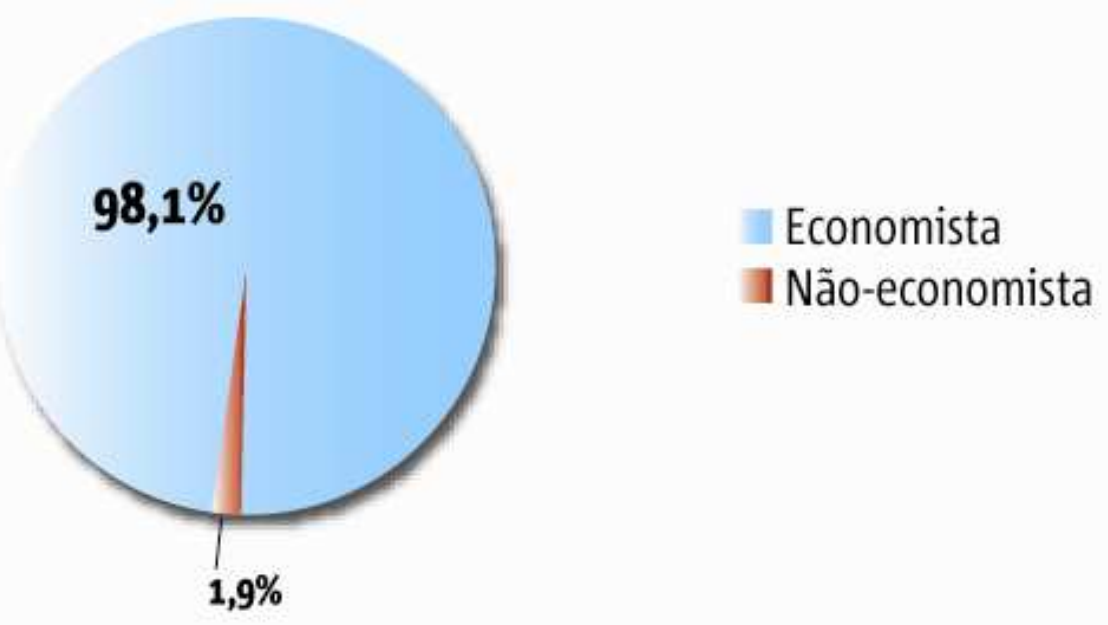

Figura 118. Perfil de graduação dos analistas/estrategistas de bancos.

\subsubsection{COMENTÁRIOS}

As respostas geraram dados que revelaram uma intencionalidade comunicacional do sistema financeiro, ainda que para os entrevistados isso possa não ser evidente. Analisandose primeiramente as respostas sobre departamentos econômicos, verifica-se que, apesar de a função declarada dessas áreas ser a elaboração de análises para clientes pagantes, $82 \%$ dos departamentos de economia enviam esse mesmo material gratuitamente para os jornalistas. Se há envio de material, há intenção de contato. 
Outro dado da pesquisa que igualmente revelou estratégias de comunicação é que quatro em cada dez instituições financeiras têm assessoria de imprensa e oferecem treinamento para seus economistas falarem com os jornalistas. $\mathrm{O}$ fato de $60 \%$ das instituições financeiras não terem assessorias de imprensa no período da pesquisa não significa que não tenham estratégias de comunicação. Oito em cada dez departamentos econômicos enviam seus estudos e comentário para os jornalistas, como já foi mostrado, sendo que em muitos casos os próprios economistas fazem as vezes do assessor de imprensa, enviando material com suas opiniões, trocando emails e oferecendo aos jornalistas os telefones de suas mesas e os celulares.

\subsection{ENTREVISTAS ABERTAS}

Relembrando: a opção por realizar entrevistas abertas com personagens da financeirização do noticiário resultou da necessidade de relacionar os resultados numéricos de conteúdo editorial com o processo social que precipitou e consolidou a financeirização. Esta parte final do trabalho traz a transcrição das dez entrevistas semi-estruturadas, pessoais e gravadas, que permitiram o diálogo entre entrevistado e entrevistador. Sete entrevistas foram gravadas em fita cassete, duas em gravador digital e outra foi anotada, conforme pedido do entrevistado.

As perguntas não foram iguais para todos os entrevistados, até porque suas experiências e as áreas de atuação são diferentes: foram ouvidos jornalistas, economistas, acadêmicos, assessores de imprensa e banqueiros. Todos foram escolhidos porque tiveram, de uma ou 
outra forma, alguma relação com o processo de financeirização em estudo. Outra justificativa pela opção metodológica de entrevistas pessoais foi o fato de permitirem o contato pessoal, o que dificulta dissimulação ou respostas falsas.

Entre todos os contatos feitos, houve muitas negativas, bem como profissionais que só quiseram falar na condição absoluta de anonimato - o que foi aceito em comum acordo com o orientador. Todas as entrevistas foram transcritas abaixo.

\subsubsection{A ESCOLHA DOS ENTREVISTADOS}

Foram tomados entrevistados a) jornalistas de redação, b) jornalistas de assessoria de imprensa, c) profissionais do sistema financeiro, d) acadêmicos.

a) Jornalistas de redação: os critérios de escolha dos profissionais foram a experiência em noticiário econômico-financeiro e o fato de todos terem testemunhado a construção do discurso financeiro na mídia impressa. Sete foram contatados, mas apenas cinco quiseram falar:

Francisco Carlos de Assis;

Neusa Ramos;

Pedro Cafardo;

Marco Antonio Rocha;

Luís Nassif. 
b) Jornalistas de assessoria de imprensa: o trabalho buscou assessores de imprensa de instituições financeiras para verificar como traçam a estratégia de comunicação de seus clientes. Foram contatados sete profissionais. Todos se recusaram prontamente a conversar com a pesquisadora, alegando que não seria ético falar sobre sua relação com os clientes. A solução foi tentar ex-assessores de imprensa, mas apenas um aceitou falar, na condição total de anonimato, tanto de seu nome quanto da instituição em que trabalhou. Depois de discutir o problema com o orientador, ficou decidido que seria melhor um depoimento anônimo, porém substancial, do que depoimento nenhum sobre questão tão importante.

c) Profissionais do sistema financeiro: outro desafio foi conseguir o depoimento de economistas do mercado financeiro para falar sobre seu relacionamento com a imprensa. Foram contatados sete profissionais, sendo que dois deles - Alexandre Schwarstsman, atual economista-chefe do Santander para a América Latina e na época, do ABN Amro, e Boris Tabacof, ex-presidente dos Bancos Safra e Banespa, aceitaram ser entrevistados "on-the-record". O diretor da área de pesquisas econômicas de um dos maiores bancos brasileiros aceitou falar, mas na condição total de anonimato, exigência que foi aceita em acordo com o orientador. Tabacof não atua mais no mercado financeiro, mas é conhecedor do sistema e testemunhou o processo de financeirização do noticiário econômico.

d) Entre os acadêmicos, Antonio Corrêa de Lacerda de Economia, professor do Departamento de Economia da Pontifícia Universidade Católica de São Paulo (PUC-SãoPaulo), foi contatado porque dá uma aula específica sobre financeirização 
do noticiário econômico no curso de pós-graduação de economia para jornalistas da escola.

\subsubsection{AS ENTREVISTAS TRANSCRITAS}

a) O trabalho começa pelo grupo jornalistas, seguindo a ordem cronológica de realização das entrevistas.

1) Francisco Carlos de Assis, jornalista há 17 anos, sendo 15 deles na área econômica. Trabalhou na Folha de S. Paulo e em O Globo. Atualmente trabalha na Agência Estado. Como repórter de economia há 15 anos, acompanhou a construção e a consolidação das fontes do mercado financeiro na imprensa. A entrevista semiestruturada levou em conta, sobretudo, a experiência diária do jornalista com os economistas, os departamentos econômicos e as assessorias de imprensa. Entrevista concedida em abril de 2008.

Pesquisadora: Como o senhor começou a ter contato com fontes do mercado financeiro? Como se chegava aos economistas do mercado financeiro?

Francisco Carlos de Assis: Os bancos criaram os departamentos de economia justamente para ser a ponte entre a instituição e a imprensa. O que eu acho que aconteceu é que o setor financeiro é o mais organizado, você encontra problema para encontrar economista de qualquer entidade representativa de outros setores que não o financeiro. Você vai 
conversar com indústria hoje, você não consegue falar com economista, um cara especializado em economia trabalhando do lado da indústria. Do comércio é a mesma coisa. Você vai falar com os diretores fica aquela coisa muito política e a coisa técnica fica de lado. Já o setor financeiro como um todo deu prioridade para essa abertura de procurar, entre aspas, buscar transparência e através da imprensa é que se faz isso, e os bancos, as corretoras, assets (gerenciadoras de ativos), eles começaram a criar os departamentos de economia exatamente por isso.

Do Plano Real pra cá, percepção minha, algumas vezes, mesmo trabalhando em outras áreas, você tentar falar com banco era uma coisa muito difícil. E depois da estabilidade da economia, acabou aquela coisa de o banco querer esconder a informação, isso ficou mais aberto. As assessorias começaram a procurar a gente pra falar, mas tem um pouco também da empresa e local em que você trabalha. Eu trabalhei na Folha e no Globo, mas percebo que aqui na Agência Estado, principalmente na Broadcast, é mais fácil conversar com alguns economistas de banco, de corretoras e de consultorias do que com outros veículos. Porque você presta informações bem especializadas, isso é um ganho. Eu tenho uma agenda hoje bem ampla de fontes, mas muitos eu consegui aqui. Depois que comecei a trabalhar aqui e comecei a falar com bancos, eles começaram a ligar, mandar e-mails e a falar com a gente cada vez mais facilmente.

\section{P: O pessoal liga para o senhor para ser ouvido?}

FCA: Nossa!, Quando eu comecei a fazer o AE Projeções, então, eu ficava o tempo todo recebendo ligações de banco não só daqui do Brasil, mas de fora também. Os correspondentes João Fabio Caminoto, de Londres, e o Fábio Alves, de Nova York, ligavam - Francisco, os economistas querem participar do trabalho, tal. Porque depois do 
Plano Real, com a estabilidade da economia, se tornou mais fácil as pessoas preverem o futuro, fazerem projeções, e os economistas querem fazer isso, eles querem mostrar isso.

\section{P: O que é o AE Projeções?}

FCA: É um produto noticioso da Agência Estado que tem como principal função afinar o discurso dos analistas de mercado. Afinar é o seguinte... a gente tem divulgações de um indicador, como o INA (Indicador do Nível de Atividade da Federação das Indústrias do Estado de São Paulo - Fiesp), aí uma determinada instituição esperava um resultado, outra esperava outra, aí você não tinha essas expectativas compiladas em um único produto. Isso existe muito nos Estados Unidos, porque lá você trabalha com expectativa para tudo, até pra campeonato de cuspe à distância. No Brasil, depois dessa estabilização da economia, passaram a ser demandado projeções, as pessoas começam a planejar seu futuro, as suas

decisões de compra e venda, suas operações financeiras. É em cima dessas expectativas que o $\mathrm{BC}$ toma suas decisões. $\mathrm{O} \mathrm{BC}$ trabalha com dois cenários, o de referência dele, que considera taxa de câmbio e Selic estáveis, mas trabalha com o do mercado, e uma das principais funções do $\mathrm{BC}$ é gerenciar expectativas, e nisso que entra o $A E$ Projeções. $\mathrm{O} A E$ Projeções acaba colocando numa única planilha projeções importantes do mercado financeiro, e isso acaba ajudando tanto as instituições especificamente, como também é acompanhado pelo BC.

\section{P: O senhor acha que os economistas de banco querem de alguma forma influenciar decisões do governo?}

FCA: Sim, um banco não ia criar um departamento econômico porque ele é bonzinho e está mais preocupado com a situação do País do que com a dele própria. 


\section{P: O que o departamento econômico faz?}

FCA: Ele analisa todas as variáveis econômicas. Dali eles fazem suas projeções e elas são passadas para as tesourarias, demais departamentos do banco, clientes, e é em cima dessas expectativas que o banco toma algumas decisões de investimento, ou de segurar investimento.

\section{P: Como o departamento econômico chega ao jornalista?}

FCA: Relatório de economia, o economista do banco conhecendo o repórter ele liga...

\section{P: Como o economista conheceria o repórter?}

FCA: Da mesma forma que a gente liga para uma instituição nova "-Olha, quem é o cara que cuida do departamento econômico?", o economista liga para nós "-Olha, quem é o jornalista que cuida de fundos? Quem é o jornalista que cuida de macroeconomia, câmbio e juros?". Você perguntou se as instituições financeiras, quando elas divulgam suas projeções, se elas querem dizer alguma coisa para o BC. Elas querem dizer alguma coisa pra o BC sim, “-Olha, nós estamos esperando isso porque estamos vendo em algum setor da economia um problema. A gente está vendo uma demanda agregada muito aquecida enquanto a indústria não está produzindo o suficiente para essa demanda, isso vai acabar implicando importações, em aumento de dólar, isso acaba indo para a inflação e prejudicando a camada mais pobre”. É óbvio que o banco não está muito preocupado com isso, ele está preocupado em chamar cliente, em mostrar que ele acerta, que as projeções dele são mais próximas da realidade. O economista fala "-Olha, o nosso fundo X rendeu tanto, porque nós trabalhamos em cima de algumas premissas que nós levantamos aqui no 
banco e nossa expectativa ficou muito próxima, quem investiu com a gente não perdeu dinheiro, se não ganhou muito, não perdeu, se perdeu, perdeu menos que os outros, mas a gente vai afinar isso aqui e no próximo vai recuperar".

Agora, o BC acompanha todo esse movimento, porque há alguns momentos em que existe uma briga, uma queda-de-braço, um cabo-de-guerra. É cada um querendo defender a sua. Muitas vezes o BC não entra na dos economistas e acaba não sancionando o que eles estão pedindo.

\section{P: Acontece isso?}

FCA: Acontece. Hoje em dia você vê menos isso. Hoje o BC está desempenhando bem o papel dele de gerenciar as expectativas. No processo de estabilização da economia, você teve um processo também de fortalecimento das instituições financeiras, e hoje eles conversam melhor. Hoje, o BC fala "-Se você não fizer isso eu vou agir", e reage a qualquer ação do mercado, e vice-versa, porque às vezes também o mercado dá uns tombos no BC, mas a ideia é essa, a de um estar monitorando o que o outro faz.

P: O senhor citou que os bancos fazem essas projeções e têm esses estudos porque estão vendo um problema lá na frente...

FCA: É, nem sempre eles acertam.

P: Esses problemas são de fato reais? Os bancos, quando fazem essas projeções, estão de fato vendo que um problema vai acontecer ou eles estão tentando induzir a opinião pública de que há um problema iminente?

FCA: Inventam... o mercado é irracional. 


\section{P: O senhor se lembra de algum exemplo de fato criado...}

FCA: Sim, às vezes o mercado quer manipular, ele não é santinho, não é mesmo. A regra do mercado é ganhar dinheiro. E aí entra o papel do BC de controlar esses ímpetos, esses exageros. Há exageros sim.

\section{P: Mas o mercado usa a mídia para criar o fato?}

FCA: Usa a mídia, a mídia usa o mercado... no nosso caso a gente usa o mercado e o mercado usa a mídia. É uma relação meio promíscua.

\section{P: Como a imprensa usa o mercado?}

FCA: Porque a gente precisa de notícia para realimentar o próprio mercado. Fica esse ciclo aí.

\section{P: Como, por exemplo, “a inflação vai sair do controle”?}

FCA: É mais para colocar medo. Você pediu em exemplo de manipulação... quando se soube que o Lula (Luiz Inácio Lula da Silva) tinha chances de ser presidente e ganhar a eleição (2002), o mercado operou pesado, à beira do caos. O mercado falava que tudo o que tinha se conseguido com o Fernando Henrique Cardoso -- estabilização, lei de responsabilidade fiscal -- ia ser jogado fora, jogado na lata do lixo, porque o Lula tinha um discurso que não era verdadeiro, o Lula era inimigo de banqueiro, o Lula era a favor da inflação. Com esse discurso de distribuir renda, de querer gerar emprego, gastar muito, que a lei de responsabilidade fiscal não ia ser respeitada, daí você teve o dólar batendo em $\mathrm{R} \$ 4$, era irreal. Aquilo não era racional. $\mathrm{O}$ mercado faz esse tipo de coisa. $\mathrm{O}$ mercado opera, $\mathrm{o}$ mercado quer eleger presidente, o mercado quer tirar presidente, um monte de coisa. 
Daí você precisa ter um BC forte para tomar algumas medidas. Eu me lembro que na época que você teve aumento de compulsório (dos bancos) $)^{57}$, aumento de juros e aquela coisa toda. Quando se tem uma disparada do dólar a inflação vem mesmo porque muito do que a gente consome aqui, produtos de limpeza, higiene, componentes para veículos, é tudo importado. Naquela época você era muito dependente do mercado externo e o mercado financeiro ele joga pra isso mesmo. Para bater na televisão, no jornal impresso, para amedrontar aquele consumidor que diz "-Não, não vou votar no Lula. Ele vai acabar com a economia, ele vai detonar com a CLT, ele vai acabar com férias, $13^{\circ}$ ". O mercado faz esse tipo de coisa mesmo, joga pesado quando interessa a ele.

E essa briga que um BC sério tem que apartar... do financeiro com a economia real. Porque quando o mercado financeiro planta uma notícia e cria um fato e isso é difundido, acaba batendo na economia real. O cara que vai comprar uma televisão, ele pensa duas vezes. “Vi um economista fulano de tal falando que vai ter uma crise, que vai todo mundo perder o emprego". Ele para e fica esperando o que vai acontecer. Aí, um BC sério tem que agir para equilibrar essa relação. Porque o mercado quer o seguinte: se ele está investindo em aumento de taxa de juros, como isso bate no consumidor final? Porque o empresário, o cara que produz, ele tem que pegar dinheiro em algum lugar emprestado, e ele vai pegar onde?

\footnotetext{
57 O depósito compulsório é um dos instrumentos que o Banco Central usa para controlar a quantidade de dinheiro que circula na economia. O mecanismo influencia o crédito disponível e as taxas de juros cobradas. Por meio do depósito compulsório, o Banco Central obriga os bancos a depositar em uma conta no próprio BC parte dos recursos captados dos seus clientes nos depósitos à vista, a prazo ou poupança. Quando reduz o compulsório, o BC dá aos bancos mais dinheiro para emprestar aos seus clientes. Isso pode ajudar a reduzir os juros bancários ou, em momentos de mais escassez de dinheiro, como agora, impedir que sequem as fontes de crédito para o consumidor e para empresas.
} 
Na mão desse sujeito, o banco. E o banco está operando juros justamente para ganhar, entendeu? E isso encarece a produção.

P: O temor dos bancos de aparecer diminuiu. Houve uma necessidade de aparecer porque o mercado de capitais começou a se consolidar e ele viu a possibilidade de ter clientes para aplicações?

FCA: É isso mesmo. Até os grandes bancos precisaram aparecer. Um exemplo é o Bradesco. Até uns quatro anos atrás ele não tinha um departamentos econômico consolidado. Tinha um monte de senhores que começaram como office boys, viravam diretores e depois estavam do departamentos econômico. O Bradesco só acabou formando um departamento bastante técnico com a compra do BBVA. Ele levou essa equipe do Otávio de Barros para lá. Porque com esse processo de globalização da economia, os bancos precisam conversar com os economistas lá fora. Não tem jeito, hoje está tudo amarrado. E você precisa de especialistas, precisa mostrar confiança, credibilidade, e o departamentos econômico tem esse papel.

Quando o Bradesco comprou o BBVA, ele estava eliminando um concorrente estrangeiro. Ele estava querendo demonstrar que tem capacidade. Tudo isso é a arma, um arsenal que as instituições mostram para os investidores lá fora, para empresas, investidores institucionais, que vêm para investir no País.

\section{P: O senhor acha que as assessorias de imprensa foram importantes para os bancos?}

FCA: Foram pelo seguinte: quando as instituições financeiras, o mercado financeiro como um todo, começou a ver a necessidade de exteriorizar suas ações, seus procedimentos, eles começaram a ir às redações e contratar os jornalistas que cobriam aquelas áreas. Aí foi 
muito legal, era uma fila de diretores de bancos acompanhando jornalistas que já conheciam as redações para apresentar, se colocar a disposição para falar. Eu vi isso. Muitos amigos meus iam para ganhar um bom dinheiro. Hoje não, hoje as assessorias querem vender para você algumas coisas que não são interessantes. Quando você pergunta se o mercado financeiro usa, manipula, manipula! Usa a mídia? Usa. Mas a mídia também usa. É uma troca, e aí você fala “-Peraí, eu não quero saber o quanto o banco investiu em não sei onde, eu não quero saber se o banco abriu uma agência em Osasco, se o banco está investindo na planta de uma fábrica, num condomínio, entendeu?" E a assessoria de imprensa meio que quer empurrar algumas coisas, fundos... para mim determinados fundos de banco não interessam. Interessa para mim, saber a projeção do cara para a inflação, porque eu sei que isso acaba interferindo na economia real de uma maneira ou de outra.

\section{P: O senhor pode ligar para a mesa de um economista diretamente? Tem o celular dele?}

FCA: Tenho.

\section{P: Da casa?}

FCA: Sim. Hoje você não pode ficar dependendo de assessoria de imprensa. Porque o economista sai para almoçar, mas você precisa escrever sua matéria o mais cedo possível. Então, hoje a gente tem telefone celular dos economistas, a gente tem de alguns da casa, a gente está fora do trabalho, eles ligam também. O pessoal se vende também, é um negócio meio posado, porque o economista-chefe de determinado banco ele quer aparecer porque isso também valoriza o passe dele. Para o Itaú, é muito bacana ter o economista dele estampado na página do jornal, do Estadão, do Valor. 
P: Para o Itaú é melhor ter o economista dele do que os donos, porque os donos ainda são mais fechados... O (presidente) Setúbal não gosta muito de falar com a mídia...

FCA: Não gostam, daí eles investem um dinheiro em profissionais para falar, exatamente.

\section{P: E esse "investe dinheiro" inclui media training?}

FCA: Inclui.

P: O pessoal comenta com o senhor se foi treinado para falar com a imprensa ou não é uma coisa que eles não comentam?

FCA: Não, eles comentam. Você acaba criando.... não uma amizade, que eu procuro evitar muito isso, mas vou a alguns almoços, em alguns cafés da manhã, por necessidade mesmo. Eu procuro manter sempre uma distância. Então, não posso dizer que são amigos, mas você acaba falando com o cara sempre, você acaba pegando uma intimidade com ele. É uma questão da gente, tenho que falar algumas coisas, mas dentro do que é estabelecido, e esses treinamentos feitos por jornalistas são bastante frequentes.

2) Neusa Pereira Ramos, jornalista há 19 anos, sempre na área de economia. Começou na TV Record, sendo toda a sua carreira voltada para economia, passou por Gazeta Mercantil, Invest News, O Estado de S.Paulo. Trabalha na Agência Estado, onde tem contato diário com o mercado financeiro. Acompanhou a construção e a consolidação das fontes do mercado financeiro na imprensa. Entrevista concedida em fevereiro de 2008. 
Pesquisadora: A senhora acompanhou in loco o período 1989/2002, do qual trata este trabalho. Como chegou às fontes do mercado financeiro para fazer seu trabalho?

Neusa Pereira Ramos: No começo da minha carreira, encontrávamos os economistas mais famosos nas coletivas da Anbid (Associação Nacional dos Bancos de Investimento), na Febraban (Federação Brasileira de Bancos) e nas coletivas de alguns bancos. Naquela época, falávamos menos com economistas de banco e mais com pessoal mais renomado, ex-diretores do Banco Central.

P: Antes de os economistas de mercado terem uma participação mais forte no noticiário, quem eram as fontes de economia?

NPR: Eram os economistas das instituições de classe, como do Dieese (Departamentos Intersindical de Estatísticas e Estudos Socioeconômicos). Mas os grandes porta-vozes eram o presidente da Fiesp (Federação das Indústrias do Estado de São Paulo) e, quando conseguia, alguns diretores ou presidentes de bancos.

\section{P: Mas era fácil falar com um presidente de banco?}

NPR: Durante um período foi até mais fácil, mas só depois que você tinha um nome no mercado e se trabalhasse num veículo que realmente tivesse peso. Se fosse no Jornal da Tarde ou na Folha da Tarde, você não era atendido. Mas se você trabalhasse num veículo mais conhecido e ele te conhecesse das coletivas, ele acabava te atendendo. Havia a divulgação do balanço do banco, e quem falava era o presidente. Também não tinha muitas questões de projeções econômicas. Na época da inflação os temas macro eram mais importantes. 
P: A senhora consegue identificar quando aconteceu essa mudança de você passar a falar mais com os economistas dos bancos?

NPR: Na minha memória, houve uma avalanche de economistas de bancos falando, querendo falar, e sendo ouvidos na época em que começou a internet (meados dos anos 1990). Você começa a receber e-mail de assessoria de imprensa oferecendo pessoa como porta-voz. Os economistas estavam sendo treinados para serem porta-vozes de bancos. Você deixa de ouvir tanto o presidente da Fiesp. Você acaba buscando novos temas da economia.

\section{P: Por que a senhora acha que a figura do economista começou a ganhar projeção?}

NPR: Na verdade você queria saber se foi uma imposição do mercado...

\section{P: Ou se o jornalismo mudou e levou essa necessidade para o mercado ser reestruturado?}

NPR: Eu acho que junta algumas coisas, inclusive os jornalistas buscando novas fontes. Eu lembro que o meu editor sempre queria ouvir o (ex-ministro) Delfim Netto, o (Marcel) Solimeo da Federação do Comércio, que também era economista. Mas você quer novas fontes, novas visões de um assunto, e os economistas de banco tinham muito mais dados, eles acompanhavam o mercado interno e externo, eles saíram um pouco do discurso político. Passava pra gente a impressão de uma opinião mais isenta, não ficava aquela coisa de "chororô" do empresário. Era "-O juro não caiu porque a inflação está assim”... parecia que era uma coisa mais profissional.

\section{P: A senhora recebia telefonemas de assessoria oferecendo economistas para falar?}


NPR: Até hoje eu recebo muito! No passado, dois bancos sempre falavam com a imprensa, e eram os dois únicos bancos estrangeiros que tinham um processo de atender a imprensa: o Citi e o Boston. Toda a vez que a gente queria uma repercussão internacional, não tinha essa cultura de ligar no exterior e falar com uma corretora do exterior como hoje. O Odair Abate, que era do Bank Boston, é um bom exemplo. Cada vez mais a assessoria de imprensa foi canalizando para você falar com o ele. Então, o Abate acabou sendo um grande porta-voz da visão internacional sobre Brasil, por parte dos bancos.

\section{P: A senhora acha que o (economista) Odair Abate foi preparado para ser o porta- voz?}

NPR: Com certeza ele já passou por media training, a gente já conversou sobre isso. Um dia, conversando comigo, ele disse que havia sumido do mapa (noticiário) por um tempo. $\mathrm{O}$ próprio banco chegou à conclusão que ele estava muito exposto... "-Hoje ele não vai dar entrevista, esse assunto, não"... Porque teve uma época que você abria o jornal, Folha, Estadão, Gazeta Mercantil, todo mundo tinha num pedacinho a declaração do Odair Abate.

O Hugo Penteado, que é do ABN (banco holandês comprado pelo Santander em meados de 2008), hoje é muito ouvido. É um economista que na verdade se especializou nessa questão da sustentabilidade, então, quando você pensa em sustentabilidade e mercado financeiro, uma das suas fontes vai ser ele. Mas no começo era uma pessoa completamente desconhecida. Eu lembro que acontecia no Estadão, numa época, você chegava, fazia a matéria do dia, aí umas seis da tarde o editor falava "-Muda tudo, porque o risco Brasil disparou, o abre do jornal amanhã é esse”. Aí você tinha uma hora para apurar uma matéria que ia ser abre do caderno, editar e despachar com foto e tudo. Aí você abria a caixa postal e estava "-Hugo Penteado fala sobre a Selic", então era a salvação da lavoura... 


\section{P: Ele supria sua necessidade de rapidez...}

NPR: “-Todo mundo que eu conheço foi embora, o que eu vou fazer? São oito horas". Às vezes, sete e meia o jornal decidia fazer a capa sobre outro assunto. Eu não tinha celular de muita gente. Aí você começa a ouvir o Hugo Penteado, sai no Estadão, aí a Folha fala “Nossa, ele falou uma coisa legal”, aí você começa a ver o cara aparecendo, se o que ele fala tem consistência.

\section{P: A senhora acha que o Hugo Penteado também teve algum preparo para lidar com a mídia?}

NPR: Acho que sim, no caso do Abate eu tenho certeza porque conversei sobre isso, mas no caso do Hugo eu não sei.

P: Os economistas-chefes foram substituindo os grandes executivos de bancos como porta vozes...

NPR: Se você tentar fazer uma matéria que não seja muito específica, que não seja muito de interesse do banco, o banqueiro não vai falar com você. Ele vai te encaminhar para o economista. Os bancos estão muito mais fechados. Todo o lobby dos bancos é feito via Febraban. Quando presidente de banco fala é alguma coisa muito específica do balanço. Ou, por exemplo, se o Itaú comprou um banco, ele vai falar sobre isso, ter um discurso meio político. Mas no dia-a-dia, presidente de banco não fala mais. Outra coisa, qualquer economista que tenha uma opinião contrária à do BC pede para não ser citado.

\section{P: Ele pode entrar na matéria apenas como fonte...}


NPR: Muitos. Se alguém acha, por exemplo, que o Ministro da Fazenda fez uma grande burrada, eles não querem se indispor com o BC nem com o Ministério.

\section{P: Em sua opinião os departamentos econômicos foram pensados para falar com a imprensa?}

NPR: Não, acho que eles foram criados por uma situação específica do sistema financeiro. Mas como a maioria das pautas era ligada ao tema de economia, o pessoal deve ter percebido essa vertente a acabou se canalizando pra isso.

P: A senhora acha que mesmo que o economista do banco fale sobre questões mais macroeconômicas, o banco considera importante ter seu nome citado junto com o do economista?

NPR: Quando é legal, sim. Acho que o banco precisa disso até para que seus clientes saibam da expertise que ele tem. Funciona como propaganda, porque as empresas querem consultoria financeira, e o banco quer mostrar seu conhecimento. Eu percebo que os analistas disputam ranking de quem acerta mais, para ser um dos Top Five do BC. Tanto que eles têm preocupações como “-Não esquece que o nome do banco se escreve assim"... Engraçado, você vê um economista que saiu de um banco estrangeiro ou brasileiro e foi para o outro e ainda não se adequou à cultura do banco, ele é proibido de dar entrevista. Fica em quarentena. Ele não foi ainda preparado como porta-voz para aquela instituição.

\section{P: Então há um preparo?}

NPR: E tem essa preocupação de que o banco seja citado. 
P: O senhor acredita que o Plano Real teve a ver com toda essa mudança, quer dizer, colocou mais os economistas de mercado financeiro na pauta?

NPR: Eu acredito que sim. Antigamente, as matérias de economia, tirando os veículos muito específicos, eram sempre ligadas à inflação. Contas públicas, externas, a inflação, então eram números macroeconômicos. Hoje você tem uma necessidade de informação, de opinião das pessoas sobre o que pode acontecer para antecipar fatos. A gente tem um horizonte de previsibilidade. Então, você tenta traçar cenários, e isso só é possível com a inflação estável.

P: Ao dar a sua previsão, o mercado acaba dando um recado para o Banco Central, o Ministério da Fazenda e os formuladores de política econômica?

NPR: Hoje, as pesquisas de opinião de mercado estão induzindo as autoridades. É muito mais importante hoje você traçar um cenário, ouvir os economistas, ouvir as opiniões... com certeza os economistas ganharam força com a estabilização de preço.

P: Além dos economistas de banco, a senhora percebe que há outras instituições tentando retomar espaço na imprensa?

NPR: Nossa! Hoje eu recebo quase todo dia email oferecendo um tal de Crivelato, um professor, todo dia. Eu recebo umas quatro ou cinco vezes por semana sugestões de economistas para serem ouvidos. A Escola de Negócios Trevisan também manda email oferecendo professores para falar diariamente. O Ibmec também conseguiu ser hoje bastante ouvido. 
3) Marco Antonio Rocha é jornalista há 50 anos. Começou em 1958, no Última Hora, de Samuel Weiner, cursou dois anos de economia na Universidade de São Paulo, mas não terminou. Trabalhou nas revistas Realidade e Visão, na Gazeta Mercantil e na TV Record. Pelo tempo de carreira, Rocha pôde ajudar a delinear o processo de mudanças no noticiário econômico desde antes da financeirização. Atualmente é editorialista do jornal O Estado de S.Paulo. Entrevista concedida em abril de 2007.

\section{Pesquisadora: O senhor percebeu uma grande mudança no conteúdo do jornalismo econômico entre as décadas de 1970, 1980 e 1990?}

Marco Antonio Rocha: Foi nos anos 70 de fato que eu comecei a trabalhar com economia, na revista Visão, em que eu era editor de economia. A diferença foi o seguinte, são basicamente três períodos. Nesse começo meu nos anos 70, você tinha uma necessidade muito grande de explicação. O jornalismo econômico era explicativo, de serviço, tudo tinha que ser explicadinho para o leitor, detalhado, problemas de juros, de alugueis, salários, enfim, era um tipo de jornalismo didático, mesmo na revista. Isso começou a ser tornar necessário talvez quando começou a crise do petróleo, no início dos anos 70, primeira crise do petróleo, os juros internacionais começaram a aumentar muito, o Brasil começou a acumular dívida externa, o público começou a ficar meio voltado pra isso, porque batia violentamente no bolso de todo mundo. Antes, o noticiário era dedicado ao café, preço do café, comércio do café, importação e exportação de café...

\section{P: Nessa época quem eram as fontes? Quem falava com os jornalistas?}


MAR: A gente ia às empresas, conversar com o presidente da Fiesp, da Federação do Comércio, alguns banqueiros como o pessoal do Comind, que depois faliu, o pessoal do Bradesco, não o Amador Aguiar, que era o dono do Bradesco, mas os diretores.

\section{P: Havia assessorias de imprensa?}

MAR: Tinha, mas não na área de economia.

\section{P: Mas e se o senhor quisesse falar com o diretor do Bradesco?}

MAR: Ia direto. Ligava pra secretária, marcava com a secretária e ia lá. Não tinha uma assessoria de imprensa que procurasse a gente para oferecer assuntos ou o palpite do seu cliente. Era uma época em que o jornalismo econômico estava se formando.

\section{P: O que mudou dos anos 1970 para os anos 1980 ?}

MAR: Por causa da crise do petróleo, do endividamento do Brasil, a inflação começou a crescer extraordinariamente e a dívida externa do Brasil começou a ficar um problema muito sério. Cresceu muito no período de 1973 a 1980. Quando chegou em 1980, 1981 houve aquela questão dos juros internacionais que subiram, e o Brasil já estava endividado e daí virou uma maçaroca. Aí a coisa ficou feia. Veio inflação atropelando tudo, e ainda teve a questão do fim do regime militar nesse período. Paradoxalmente, o jornalismo econômico se beneficiou da ditadura, quando as notícias políticas perderam espaço. Na década de 1980, quando começou a redemocratização, o noticiário político voltou a crescer em detrimento um pouco do noticiário econômico. Mas só que aí já tinha o problema da inflação e da dívida externa. 
P: Nesse período da inflação, quem eram as fontes do repórter e do colunista de economia?

MAR: Começou a ter muita gente do governo, por causa da dívida externa e da inflação. O pessoal do Banco Central, do Ministério da Fazenda, do Ipea (Instituto de Pesquisas Econômicas Aplicadas, do governo federal). Era muito fácil o acesso ao governo. A gente chegava e dava um recado para a secretária, o chefe de gabinete, "-Olha, a gente está aqui, viemos falar com o ministro". Dali a pouco, 10 minutos, 15 minutos, “-Manda entrar". Mas naquela época, a gente precisava também ir a Brasília, não tinha esse negócio de ter um cara plantado no gabinete a semana inteira. O governo passou a ser a fonte principal do noticiário econômico, ainda hoje é assim.

P: O senhor percebe que houve a entrada de fontes do mercado financeiro no noticiário econômico?

MAR: Percebo nitidamente. O mercado financeiro se tornou muito mais dinâmico, ele era uma coisa parada, sem interesse, era um autômato, que funcionava sozinho. A partir da disparada da inflação, o mercado financeiro teve que dar conta deste problema. Teve que criar instrumentos de defesa contra a inflação, de investimento. A partir desse período, se formou uma porção de instituições não-bancárias: corretoras, corretoras de valores, financeiras, instituições de poupança e empréstimo, uma porção de interlocutores entraram nesse mercado, ou ao redor dos bancos ou autonomamente.

\section{P: Como esse pessoal chegou aos jornalistas, como eles se tornaram fontes?}

MAR: Porque eles eram muito ativos. Era uma gente muito jovem, que não tinha medo de falar as coisas, não tinha porque não falar, não era como os banqueiros, figuras reservadas, 
misteriosas, discretas, silenciosas, banqueiros têm a fama de não falar até hoje. Não dão entrevistas, como o Amador Aguiar (Bradesco). Esses yuppies, como se dizia na época, do mercado financeiro, viviam nos bares que os jornalistas frequentavam, na noite, viviam indo em coisas de jornalistas, viviam chamando os jornalistas para conversas, para papo, para café da manhã... então, tinham muito mais condições de se tornarem fontes da imprensa. Eles eram bastante acessíveis, queriam aparecer. Ao mesmo tempo, as instituições contrataram assessorias de imprensa.

\section{P: Então houve uma estratégia de comunicação...}

MAR: Sim. Essas estratégias de comunicação das instituições começaram a ser montadas a partir da redemocratização, de 1985, 1986. Eu mesmo montei uma empresa de comunicação nessa época, a XYZ.

\section{P: E o senhor trabalhava com pessoal do mercado financeiro?}

MAR: Do mercado. Nosso primeiro freguês foi a Bolsa de Mercadorias, não existia a BM\&F, era a chamada Bolsinha, do Nei Castro Alves. Quando ele soube que eu estava montando minha empresa de comunicação, ele falou que tinha interesse e fizemos um contrato. As empresas de comunicação estavam começando e o mercado financeiro estava interessado em se comunicar.

\section{P: o senhor acha que em algum momento houve um predomínio dos assuntos de interesse do mercado financeiro no noticiário econômico?}

MAR: Houve. Não proposital, mas impulsionado pelo problema da inflação. A inflação é que ditava isso. Uma inflação que chegava a $80 \%$ ao ano... é claro que o mercado 
financeiro ou era vítima ou era personagem principal da situação. Eram eles que ditavam as regras de como escapar dessa armadilha ou de como lidar com esse problema, era o pessoal do mercado financeiro quem tinha as receitas. Os planos econômicos criaram uma bagunça: tablitas, sequestros de contas bancárias, confiscos, impostos extraordinários... aqueles planos que não deram certo exacerbaram o papel que o mercado financeiro tinha na imprensa, deram mais destaque ainda.

\section{P: E quando a inflação começou a ser controlada, o que mudou em termos de fontes, de discurso econômico?}

MAR: A partir do Plano Real, com a relativa estabilização da moeda, a valorização e tudo mais, começou-se a discutir política econômica, a estratégia de desenvolvimento, política fiscal, investimentos, não-investimentos, emprego...

\section{P: O senhor acha que as fontes do mercado financeiro perderam um pouco de espaço nesse contexto?}

MAR: Não é mais tão importante saber quanto está rendendo a caderneta de poupança, um DI, CDI, qual a rentabilidade do dinheiro. É importante, mais não tem a importância que tinha há 10, 15 anos. Agora, o assunto de dois, quatro anos pra cá são ações, investimentos também ligados ao mercado financeiro, mas também ao desenvolvimento da economia. $\mathrm{O}$ problema anterior era de proteger o dinheiro contra a inflação. Agora, o problema é de como aplicar o dinheiro.

4) Pedro Cafardo é jornalista de economia desde que iniciou a carreira na Folha de S.Paulo, em 1971. Foi editor na Folha, na Gazeta Mercantil, revista Afinal, no 
Estado de S.Paulo e no Valor Econômico, onde é editor-executivo. Entrevista concedida em junho de 2008.

\section{Pesquisadora: Que mudanças o senhor mais percebe no noticiário econômico brasileiro?}

Pedro Cafardo: O jornalismo de economia é muito recente no País. Antes do fechamento político, em 1968, a economia ocupava pouco espaço na imprensa escrita e menos ainda nos outros meios, como rádio e televisão. No Estado de S.Paulo, por exemplo, a seção de economia ficava lá no fim do jornal, depois do Esporte e do Turfe. Era um noticiário muito técnico feito por alguns jornalistas especializados, como Frederico Heller e Robert Appy. Na Folha, havia o Mario Mazzei Guimarães.

Com o fechamento político, os jornais tiveram de encolher suas seções de política e, ao mesmo tempo, veio o boom econômico dos anos 1970, comandado por Delfim Netto. A máquina oficial bombardeava os jornais com notícias positivas sobre o crescimento da economia, dos investimentos, da bolsa de valores - que, aliás, bombou em 1971 e quebrou muita gente - etc. Era muito tranquilo fazer essa cobertura econômica, porque era prógoverno e raramente sofria censura. Portanto, os jornais de todo o País engordaram suas equipes de economia e emagreceram as de política.

\section{P: Quem eram as fontes do noticiário econômico naquele período?}

PC: Havia três tipos de fontes. As oficiais, ministros e outras autoridades do governo, eram sem dúvida as mais importantes. O ministro Delfim Netto, por exemplo, tinha o hábito de receber toda segunda-feira, bem cedo, os principais editores para conversas reservadas no 
ministério, na Avenida Prestes Maia, em São Paulo, antes de voar para Brasília. Esses encontros eram muito importantes para balizar a cobertura de economia, saber das medidas que viriam e até para sentir a temperatura da política. Eu era repórter nessa época e nunca consegui entrar numa dessas reuniões matinais das segundas-feiras. Eram frequentadores dessas reuniões o Rolf Kuntz, Robert Appy, Roberto Muller, José Roberto Guzzo e outros. O segundo bloco de fontes eram os empresários. Imbuídos do espírito oficial, eles também davam informações positivas e rasgavam elogios à política econômica do governo. Só por volta de 1978 é que começou a se formar um grupo de empresário que, apesar de apoiar a política econômica, pedia abertura política. Eram Antonio Ermírio de Moraes, Cláudio Bardella, José Mindlin e outros, reunidos em um fórum da Gazeta Mercantil. Pela primeira vez desde 1964, empresários tinham coragem de falar em abertura. Eles passaram então a ser importante fonte para o noticiário econômico.

O terceiro bloco de fontes eram os economistas. Nesse bloco só havia lugar para os que contestavam a política econômica. Era gente de muita coragem. A principal crítica que eles faziam era sobre a distribuição de renda. Apesar do crescimento da economia, isso estava ocorrendo sem a necessária distribuição. E tinham razão, como se pôde constatar nas décadas seguintes. Entre esses economistas estavam Celso Furtado, o maior de todos os críticos da política econômica do regime militar, Luiz Carlos Bresser-Pereira, José Serra, Eduardo Suplicy, João Sayad, Pedro Malan. Todos, sem exceção, eram da academia.

\section{P: Não se ouvia pessoal de banco?}

PC: Não havia nessa época nenhum economista de banco com espaço entre as fontes dos jornais, por razões óbvias: o governo não admitiria que um economista de um grande banco fizesse crítica à política econômica. Se fizesse, estaria demitido. Os banqueiros eram 
fechados com o governo. Então, só professores tinham coragem e independência para fazer críticas.

Lembro que naquela época, meados dos anos 1970, Octávio Frias de Oliveira, inteligentemente chamou para a Folha, como conselheiros e articulistas, alguns desses economistas da oposição, entre eles Serra e Suplicy. A atuação desses economistas foi um tremendo diferencial para a Folha, porque até então só havia reportagens e artigos favoráveis à política econômica nos jornais. Nessa época, a Folha, por exemplo, havia suprimido até seu editorial. Acredite: a Folha não tinha editorial. Espertamente, Frias usava a opinião de terceiros para criticar o governo, com a ressalva de que a Folha não se responsabilizava pela opinião dos articulistas.

\section{P: Quando, então, os economistas de bancos passaram a ser fontes:}

PC: Feitas essas observações, dá para imaginar quando os economistas de bancos passaram a se tornar fontes importantes do jornal: quando começou a abertura política, em meados dos anos 1980. Ainda havia o regime militar, mas estava muito debilitado no governo João Figueiredo (1979-1985).

Nos anos 1980, surgiram com grande ênfase seções do tipo "Seu dinheiro", voltadas para a classe média que sonhava com a casa própria e começava a fazer aplicações financeiras num momento em que a inflação corroia qualquer dinheiro deixado na conta corrente. Tudo o que entrasse na conta, mesmo que fosse permanecer apenas alguns dias, tinha de ser aplicado. Era a época do "overnight". Predominava o jornalismo de serviço financeiro em oposição ao macroeconômico que dominou os anos de chumbo da ditadura militar. 
P: Correto, mas hoje vemos a predominância do pensamento financeiro no noticiário macroeconômico, que lida com os grandes temas da política econômica e não apenas com o mercado financeiro...

PC: Primeiro, ainda lá atrás, as direções dos jornais e das seções de economia começaram a perceber que suas velhas fontes, os economistas das universidades, eram exageradamente teóricas e fortemente engajadas politicamente, portanto com viés ideológico muito marcante. Queriam informações de gente que estava mais envolvida com o dia a dia do crescente mercado financeiro. Então, ganharam espaço os economistas dos bancos.

Mas esse tipo de jornalismo de serviço financeiro entrou em declínio depois do Plano Real, em 1994, por razões óbvias: com a inflação baixa, ficou muito menos importante saber como proteger o dinheiro.

\section{P: Mas desde então eles mantêm espaço como fontes. Por quê?}

PC: Eles nunca mais perderiam sua importância pela simples razão de que o setor financeiro passou a predominar na economia desde então. Nos anos 1990, o Brasil foi um fracasso produtivo. O crescimento do PIB do País foi um dos mais baixos entre os emergentes, porque predominou o neoliberalismo, a política de juros altos e houve total ausência de preocupação com planos de desenvolvimento. A ideia era a de que o mercado promoveria o desenvolvimento. Então, toda a força ao mercado. O governo deveria ser cada vez mais enxuto e manter política fiscal e monetária austera.

\section{P: Mas o senhor não considera que houve exageros por aqui?}

PC: Nesse ambiente, o setor financeiro se agigantou. Quando tropeçou, e os bancos foram ameaçados de quebra, no primeiro governo Fernando Henrique Cardoso, houve o Proer 
(Programa de Estímulo à Reestruturação e ao Fortalecimento do Sistema Financeiro Nacional), o macroprograma de ajuda com dinheiro público.

Hoje, os economistas de bancos ainda são valorizados como fontes, até porque o setor financeiro continua dando cartas. A política de juros ainda proporciona elevados lucros na intermediação financeira, embora no governo Luiz Inácio Lula da Silva se tenha olhado com mais cuidado para o investimento produtivo. Mas a opinião dessas fontes do setor financeiro já começa a ser vista com muita desconfiança. Elas tendem naturalmente a defender políticas que beneficiem o setor. Por exemplo: jamais serão críticos da política de juros altos e jamais indicarão os erros cometidos pelo Banco Central nos últimos anos, quando poderia ter reduzido mais os juros e nao o fez. Tudo é muito simples: quanto mais altos os juros, melhor será o resultado dos bancos. Se um economista de banco disser que isso está errado, obviamente, estará demitido. Eles são, portanto, fontes duvidosas.

Do Plano Real para cá, começou a crescer o jornalismo financeiro de negócios. Na época o regime militar, Empresas e Negócios eram tratados apenas em algumas colunas. Jamais se fazia matéria com empresas na grande imprensa. O nome de uma empresa em um título? Raramente. Lembro-me que certa vez, nos anos 1970, tivemos a ideia de fazer algumas tabelas para comparar os preços dos supermercados. Ao saber da iniciativa, o dono da Folha Carlos Caldeira (sócio de Octávio Frias) disse o seguinte: “-Não quero essa tabela. Se os supermercados quiserem, que paguem anúncio no jornal.”

O jornalismo financeiro de negócios passa a ser ainda mais importante quando um grande número de empresas passa a abrir capital e lançar ações no mercado, porque naturalmente os acionistas minoritários têm o interesse de acompanhar as atividades da empresa. Os balanços das companhias têm chamadas nas primeiras páginas, assim como fusões e aquisições. O jornalismo de negócios então se mistura com o acompanhamento do mercado 
financeiro. No Valor de hoje, por exemplo, a seção de Companhias Abertas foi incluída no mesmo caderno que trata de investimentos financeiros. São faces da mesma moeda.

5) Luís Nassif é jornalista de economia desde o início da década de 1970, quando começou a trabalhar na Veja. Trabalhou no Jornal da Tarde, na Folha de S. Paulo e no projeto do instituto Datafolha de pesquisa. Em 1985, criou o programa Dinheiro Vivo, na TV Gazeta de São Paulo. Em 1987, fundou a Agência Dinheiro Vivo, de informações em tempo real. Entre os jornalistas, Nassif é o que mais abertamente critica a "inconsistência e ideologização" do noticiário econômico, promovidas pela predominância de fontes e temas do mercado financeiro. Discutiu essas questões em pelo menos dois de seus livros: O Jornalismo dos Anos 90, de 2003, e Os Cabeçasde-planilha, de 2007, em que revela jogadas especulativas no mercado futuro de câmbio. Depoimento concedido em maio de 2009.

\section{Pesquisadora: Considerando que o senhor é uma pessoa que vivenciou as transformações do jornalismo nas últimas décadas, poderia dizer se e como ocorreu o predomínio do pensamento neoliberal na imprensa?}

Luís Nassif: As fontes da cobertura estão ligadas a um modelo econômico. Até os anos 80, esse modelo econômico era baseado muito em reservas de mercado. A principal fonte econômica era a Fiesp, depois tinha Abimaq, Abdib, você tinha uma cobertura muito fraca 
da Febraban ${ }^{58}$, e não tinha a figura dos bancos de investimento ainda. A cobertura em si era muito pequena, tanto que fui talvez o primeiro a cobrir mais especificamente mercado com o meu programa, o Dinheiro Vivo, na TV Gazeta. A gente cobria mercado, o que ocorria com esses novos agentes aí, bancos de investimento que estavam surgindo, Garantia, Pactual, que trabalhavam muito com informações privilegiadas. Em 89 quando eu montei a (agência de informações) Dinheiro Vivo a gente montou um padrão de cobertura de mercado que foi mantido pela Agência Estado. Quando a Agência Estado comprou a Broadcast ela contratou a equipe minha. Até um tempo atrás estava todo mundo lá. Entram em cena os novos agentes da opinião pública: primeiro os economistas do (plano) Cruzado, depois os do Real e a partir de 90, com a privatização, eles ganham muita força econômica e política.

\section{P: Na sua avaliação, como a mídia foi conquistada pelo pessoal do mercado?}

LN: Foi conquistada pelo seguinte... Você tem um modelo que vem lá...Você pega o The Wall Stree Journal (Estados Unidos), aí você pega o Citi Group (Estados Unidos) que nos ano 40 começa a produzir uma carta econômica que tem alguma repercussão. No final dos anos 80 você já tinha essa visão do mercado financeiro, do mercado se internacionalizando, os primeiros bancos começam a ir para o Exterior, as análises de conjuntura começam a se formar em torno do Banco Central no conceito de "open market". Você tem que definir taxa de juros. Aquela inflação alta faz com que a taxa de juros da semana seguinte fosse algo disputado a tapa. Se você errasse a taxa de juros da semana seguinte, você perdia dinheiro. Então começa a ter uma análise de conjuntura. Os bancos não tinham ainda

\footnotetext{
${ }^{58}$ Fiesp, Federação das Indústrias do Estado de São Paulo; Abdib, Associação Brasileira das Indústrias de Base e Infraestutura; Abimaq, Associação Brasileira da Indústria de Máquinas e Equipamentos; Febraban, Federação Brasileira de Bancos.
} 
estrutura de departamento econômico. Tanto que a primeira carta de conjuntura que saiu aí foi Análise, que era do Arlindo, depois o Guia Financeiro, que era da Dinheiro Vivo. Daí nós compramos a Análise.

\section{P: Isso antes da proliferação dos departamentos econômicos?}

LN: Antes. Havia toda uma ideologia por trás disso: o Estado era corrupto, o Estado emperrava todo desenvolvimento, impedia a livre iniciativa, você tinha aquele exemplo da reserva de mercado (informática) que tinha atrasado muito o País, então você tinha um longo caminho, que é você cuidar dos fundamentos da economia e liberar o mercado. Liberar o mercado significa você criar as condições para que venham fluxos de capitais aqui que ajudem a injetar dinheiro na economia e desenvolver o País, essa aí era a habilidade ideológica. E no dia a dia, quando começam as avaliações econômicas, você tinha um modelo que vinha lá dos Estados Unidos. Para o capital circular, era preciso que houvesse o mesmo padrão de análise, o que é uma maluquice, porque cada país tem suas características bem específicas. Então essa uniformização, com os mercados internacionais se integrando, o grande capital brasileiro passa também a ser afetado pelo que acontece lá fora. Então a cobertura passa a se dar em cima dessa análise. Então você tem Wall Street. Os bancos americanos geravam análises, essas análises iam para as empresas americanas e depois vinham para as filiais dos bancos estrangeiros aqui.

\section{P: Mas essas análises são análises para clientes. Por que elas iam para a imprensa?}

LN: Porque a imprensa tinha que dar ... se o cliente lia... quem passou a ser o leitor de notícia econômica? Se no âmbito do governo você não tinha política industrial... você não tinha mais a bandeira da defesa da produção interna, você não tinha mais a bandeira do 
emprego... quer dizer, se o próprio governo definia como única bandeira a criação de condições no mercado, e o mercado passou a gerar um volume de informação monumental - muita masturbação mas gerava um grande número de informações - a cobertura econômica foi para onde achava que era o novo modelo.

\section{P: Sem crítica alguma?}

LN: Sem crítica alguma.

\section{P: E o fato de a imprensa nunca ter criticado o modelo é um problema para o senhor?}

LN: Total, total. Quando comecei, nos anos 70, 80, a preponderância da parte econômica repetia slogans, termos, conceitos fechados no economês para dar impressão de conhecimento. Então, esse tipo de subeconomia que se aprendia, que a imprensa reprisava, não era uma economia aprofundada, o cara não é um economista, não estudou, grande parte dos economistas também ficava na superfícial. Você passava a ser um analista econômico, você pega um (Carlos Alberto) Sardenberg e outros aí, você é um analista econômico em cima de chavões. "-Se ele tem que aumentar o gasto público, tem que elevar juros...” . A economia é muito mais que isso, você tem que ter relação de causalidades, causa e efeito. Por que se aumentar os gastos públicos você tem que aumentar a taxa de juros? Ora, o jornalismo tinha de ter questionado isso, chegar no economista e falar "-qual a correlação?”. Às vezes tem a ver, as vezes não tem. A correlação, o economista vai mostrar se ele conhece ou se ele está repetindo... e esse exercício foi feito por pouquíssimos jornalistas econômicos. 
P: Será que isso nunca foi feito porque o jornalista se sente despreparado para lidar com o saber científico do economista? Não estou falando de colunista, estou falando do repórter, daquele cara que faz o trabalho "braçal"...

LN: Você tem economistas que fizeram nome aí sendo abastecidos diariamente pela Tendências Consultoria ${ }^{59}$. E daí o seguinte, para você chegar no leitor, não é análise profunda, é o chavão que interessa. Se você pegar o nível de conversa de alguns colegas meus do rádio e pegar um bom leitor de jornal em um bar, o nível é o mesmo. É chavão. “Você não pode questionar os juros.” “-Todo gasto público é por definição ruim).” “Políticas sociais não criam países competitivos.” É tudo o contrário do que...

\section{P: Mas isso tudo está vestido com o manto da cientificidade, não é? O próprio jornalista se sente intimidado em questionar...}

LN: O que acontece, nós estamos falando do repórter. Acima do repórter tem o redator que nunca conhece muita coisa. E tem o editor de uma primeira página que não conhece economia. Então você não ousa divulgar notícias ou enfoques novos. Para se sentir seguro você tem que divulgar o enfoque do que foi feito ontem, antes de ontem. Então, chega uma avaliação da Maria da Conceição Tavares sobre economia. Só que o editor usa o mesmo sistema da coluna social. Saiu numa coluna porque saiu em outra antes. Então, a imagem dela é de atrasada, dinossaura, dos anos 80, então não entra. Mailson, que é um cretino, Mailson é o cara mais primário que se tem em matéria de analise econômica. Saiu ontem, saiu antes de ontem, saiu antes de anteontem. Então não tem risco. Publica o Mailson. E

\footnotetext{
${ }^{59}$ Uma das maiores do Brasil, pertencente ao ex-ministro da Fazenda Mailson da Nóbrega, ao ex-presidente do Banco Central Gustavo Loyola e ao investidor Natan Blanche.
} 
como também não há um interesse de fazer aquela coisa mais aprofundada, então você repete o chavão.

\section{P: E o que o senhor acha que isso pode trazer para o leitor? O que o leitor perde com esse noticiário enviesado?}

LN: Uma parte dos jornalistas percebia essa maluquice... questionava. Outra parte não questionava. O jornalista trabalha por sinais que vêm da chefia, que veem dos leitores. Então, se eu falo isso, o meu editor, o meu diretor vai considerar que eu estou anacrônico, que eu faço parte do time atrasado. Então você vai pela onda. Esse efeito manada, por exemplo, ocorre no mercado. No mercado você tem antes da crise cambial de janeiro de 99, em dezembro, 13 de um total de 15 departamentos econômicos dizendo que o câmbio ia ficar o mesmo. Só que estava explodindo o País. Então, se o cara de banco, o economista tem esse receio de inovar, de dar uma opinião diferente, o jornalista mais ainda, porque o jornalista não tem o conhecimento adequado pra poder questionar isso. A economia não é uma ciência exata. Então, a possibilidade de embromação é muito grande. Primeiro, porque as relações entre o fato e a consequência são muito longas. Uma besteira que você comete com o câmbio aqui muitas vezes vai explodir um ano depois. Depois, uma das características desse tipo de jornalismo "fast food" é que qualquer medida tem prós e contras. O grande conhecedor, ele sabe separar, fazer a conta final. Esses economistas de mercado passam para imprensa... eles pegam aqueles aspectos que, digamos, se ele quer pegar aquela análise com aquela informação, e dá os pontos negativos, toda análise econômica tem pontos positivos e negativos. Para o cara saber qual avaliação econômica é boa ele tem que ter uma visão de longo prazo que o estudo básico da economia te passa. 
Mas essa embromação que veio dessa financeirização, os caras deturparam até conceitos básicos.

\section{P: Explique o que o senhor chama de embromação.}

LN: Vamos pegar um caso aqui... se você aprecia o câmbio, você tira a competitividade dos produtos brasileiros. A médio prazo, tirando a competitividade, você reduz o emprego e o desenvolvimento do País. Dependendo do nível de apreciação, você cria uma crise externa, como já aconteceu em 94, 99, 2002 e quase acontece agora se não tivesse vindo a crise (que depreciou um pouco o real ante o dólar). Só que quando você vai entrevistar o economista, o que ele fala? "-Graças a essa apreciação, melhorou o poder aquisitivo do brasileiro. Melhorando o poder aquisitivo do brasileiro vai melhorar o mercado de consumo, você vai ter mais consumo e mais desenvolvimento". Ou seja, se você cria um modelo que não é sustentável, que vai resultar numa crise mais à frente, que não resulte em desenvolvimento industrial, que não resulta em aprimoramento tecnológico, que não resulta em geração de emprego, ele vai melar mais adiante. Mas o cara salienta aspectos positivos que não são mais relevantes para fazer a análise do modelo. Isso vale pra tudo.

\section{P: Mas o senhor acha que isso também tem a ver com falta de conhecimento do economista que está conversando com o jornalista?}

LN: Tem, tem a ver com manipulação de uma parte, outra parte é que tem um segundo time de economistas que repete o que vem de cima. Mas é manipulação, evidente. Você pega uma semana antes de estourar o câmbio, o Mailson e o Natan Blanche diziam que quem era a favor da mudança de câmbio era do arco do atraso. Então você ideologiza isso e divide entre bons e maus, quem fala isso é atrasado...Isso é embromação. Embromação é essa 
ideia de que se você fizer a lição de casa você ganha o investment grade (grau de investimento conferido pelas agências de classificação de risco, que supostamente medem a capacidade de um país saldar suas dívidas), e se você ganha $o$ investment grade você ganha a felicidade eterna.

\section{P: E por que o senhor acha que isso é embromação?}

LN: Veja bem, o que é o "investment grade"? O "investment grade" (grau de investimento) analisa a capacidade de pagamento de um país. Se para garantir essa capacidade de pagamento eu jogo a taxa de juros lá em cima sem necessidade, corto investimentos em infraestrutura, corto gastos em educação, em inovação. Para manter a capacidade de pagamento eu não estou desenvolvendo. Esse capital que é analisado pelas agências de risco é um capital que entra e sai e não traz desenvolvimento, como não trouxe.

P: Como o senhor acha que o jornalista, que o repórter, gente que está lá na redação, no dia a dia dos jornais, pode se preparar para enfrentar esse discurso?

LN: A crise está se incumbindo disso.

\section{P: Mas as fontes continuam as mesmas...}

LN: Você pega o espaço que tem hoje um Delfim (Netto), um (Luiz Gonzaga) Belluzzo, o pessoal da Universidade Federal do Rio de Janeiro, o espaço é maior do que antes. Esse (economista de banco, com grande visibilidade, entrevistado mais abaixo) Alexandre Schwartsman era visto como um gênio, mas é um cretino.

\section{P: Ele é muito acessível, você liga pra mesa dele...}


LN: ...está em permanente disponibilidade. Você pega o Mailson. O Mailson não engana ninguém mais. Pega o Octavio de Barros (economista e diretor do Bradesco), ele é muito meticuloso, mas a capacidade de análise macro dele é zero. O (Fábio) Giambiagi, esses caras desapareceram. Raul Velloso. Esse é um cara que conhece contas públicas, de repente virou macroeconomista. Você pega o Eduardo Giannetti, é um filósofo, é um ótimo filósofo...virou macroeconomista. Essa falta de discernimento, isso aí surge a partir do despreparo das redações.

\section{P: Como dá para se preparar? O senhor já refletiu sobre isso?}

LN: Sei lá, ué. Dentro do modelo atual você não tinha competição entre os jornais, você tinha o discurso único...Quero dizer, a partir de 2002, 2003, 2004, com a crise econômica, eles fizeram um pacto entre eles de um discurso único, e esse discurso único matou a competição. A Folha faz um jornalismo econômico ruim, mas é o mesmo que o Estado faz, é o mesmo que $O$ Globo faz. Então, com a abertura da internet para outras formas de questionamento, eles vão ter que mudar.

\section{P: O senhor acha?}

LN: Acho. Ah, vão. Nós estamos passando por uma fase agora de mudança estrutural na economia, na política, na vida brasileira.

\section{P: Eu queria que o senhor falasse do surgimento da sua reflexão sobre os "cabeças- de-planilha", de onde veio essa sua percepção?}

LN: Eu estive em 2002 no banco Santander, na Espanha, em um seminário do qual participaram o (Enrique) Iglesias (ex-Banco Mundial), jornalistas da imprensa econômica 
espanhola, El País e outros, e também as multinacionais espanholas que estavam vindo para cá. Para quem estava de fora, era nítido que a vinda para a América Latina, para o Brasil, salvou a Espanha, porque as empresas seriam devoradas pelas multinacionais alemãs, francesas. Você pega a discussão dos jornalistas econômicos lá, então eles falavam das empresas corruptas da América Latina gastando dinheiro das velhinhas deles.

E para mim ficou claro isso, desde 2001, 2002. Eles pegavam uma situação momentânea de queda e projetavam por anos. No momento anterior, quando a economia estava bem, eles pegavam um momento bom e projetavam por anos. Então, não havia nenhum conhecimento sobre as características específicas da economia. Em 1982 eu estava no Jornal da Tarde, fui cobrir uma reunião da Anpec (Associação Nacional dos Centros de Pós-Graduação em Economia) em Olinda. E foi a primeira vez que eu vi a apresentação dos modelitos. Então o cara conta um modelo de economia para defender determinada tese.

\section{P: É planilha Excel?}

LN: Não, eu digo o modelo ainda sem a matemática. Nesse modelo você monta o que é o país: as relações entre câmbio, produção, isso e aquilo. O cara contava o modelo para justificar uma tese. Daí na hora de a mesa questionar, “-Ah, mas você não colocou o trabalho tal aí, como é que fica?” O cara colocava o trabalho. “-Ah, mas você não colocou agricultura." Aí o cara colocava agricultura. Aí, à medida que ele ia colocando os elementos, o modelo dele deixava de funcionar. No Brasil, o que aconteceu com essa questão dos "cabeças-de-planilha" é que foi em cima da planilha do Ilan Goldfajn (ex-BC). Todo o mercado, quando ia fazer a pesquisa Focus (do BC), eles não queriam saber qual era a estimativa deles para a inflação. Eles tentavam adivinhar o que o Banco Central pensava sobre inflação. Se eles estivessem certos e o Banco Central errado, e eles apostassem no 
que eles achavam certo, havia ganho. A planilha do Ilan é uma coisa que todo mundo queria reproduzir.

\section{P: Quando foi isso, mais ou menos?}

LN: Em 2002.

\section{P:Ele (Ilan Goldfajn) estava no Banco Central?}

LN: Estava no Banco Central.

\section{P: A utilização da planilha é vendida como algo absolutamente matemático, um} modelo limpo, livre de influências políticas, científico. Isso é muito sedutor, não é?

LN: Vou te dar um exemplo que ocorreu em 1994. O governo abre a economia, amplia aquela apreciação do Real, as contas externas indo para o vinagre... O governo desesperado porque achava que as exportações não estavam dando...Lembro que escrevi uma coluna dizendo "-Olha, cotação leva um tempo até que os importadores aprendam a importar, e quando aprenderem vai ver uma enxurrada de cotações que vai sufocar a economia". O (José) Serra era ministro do Planejamento, no segundo semestre de 1994, ligou para mim: “-Você está acompanhando os últimos estudos do Paul Krugman?” Eu falei “-Não”. Eu nem sabia quem era o Paul Krugman. Ele disse “-Porque nas teses dele ele está justamente discutindo essa defasagem..." Eu fui a Uberlândia dar uma palestra para uns atacadistas lá, perguntei a eles por que não estavam importando e eles disseram que leva um tempo até aprender. Ou seja, esse contato com o mundo real os caras não tinham. Eles montavam uma planilha, a planilha dizia o seguinte: "-Vai ter uma depreciação de cambio de x, mas se a economia tiver um ganho de produtividade y, compensa". Para saber se a economia vai 
ter aquele ganho de produtividade, você precisa conhecer, você tem de ter uma noção de grandes números, qual a capacidade de o empresário ter esse ganho de produtividade, qual a rapidez com que o Executivo consegue fazer reformas, qual a resistência que o Congresso vai impor a reformas, ou seja, um conjunto de fatores que interfere na economia, que esse modelo ignora.

\section{P: Mas ainda hoje há muita oferta de estudos de consultorias, de bancos. Muitos estudos que são baseados nesses estudos de planilha...}

LN: O que eu digo é o seguinte: você tem o estrategista e o calculista. O estrategista é aquele cara experiente, criativo, ele tem a visão de conjunto. É que nem o jogador de xadrez. Tem uma entrevista com o (Garry) Kasparov na Veja muito interessante. No xadrez, as probabilidades são infinitas. Então você tem que saber qual o caminho correto e isso você só consegue com a intuição. Então você pega um economista experiente, um Delfim, pega um Guilherme da Silva Dias. Pega o (Yoshiaki) Nakano. Eles têm noções muito claras das grandes linhas, do quê influencia o quê. A partir do momento que você tem essa noção, você pega um Alexandre Schwartsman e fala “-Faz um cálculo aí pra mim sobre a influência do câmbio no saldo comercial", uma coisa assim. O problema é que esses caras do cálculo são técnicos, eles não são os criadores. Eles não são os estrategistas, eles são os economistas menores, eles são os economistas que fazem as contas. Esses caras, em cima de modelitos que trouxeram de fora, acharam que tinham conhecimento, mas não sabem pensam fora do modelo.

\section{P: Mas a ideia de que o modelo é científico e por isso funciona passado para a sociedade via imprensa?}


LN: Foi, foi. Aí quando você pega o próprio Alexandre, o Octavio, não é nem o modelo econométrico, que o jornalista não estava em condição de analisar. Mas a segurança com que ele fala besteira. Eles são taxativos. Se o cara erra você não cobra. O Mailson e o pessoal da Tendências, eles erraram todos os grandes fatos econômicos que aconteceram de 1994 a 2003. Todos. Eles não previram a crise do México em janeiro de 94/95, não previram a crise brasileira, não previram a explosão do câmbio em 99, não previram a quebra da Argentina, não previram a explosão do câmbio em 2002...

P: Mas é uma empresa que deve ter um número muito grande de clientes...

LN: Porque a imprensa dá essa retaguarda.

P: O fato de uma consultoria, banco ou administradora de ativos aparecer na imprensa aumenta sua base de clientes?

LN: Claro.

P: O senhor acha que a instituição quer aparecer na mídia também por conta disso?

LN: Claro. Interessa por vários motivos. O primeiro é esse negócio, se ele é consultoria atrai clientes, se ele é ligado ao banco, ele dá visibilidade para o banco. E outra coisa é o seguinte, em momentos de turbulência, o que ele fala influencia o mercado. Então ele fala amarrado com o que o operador do banco dele está fazendo. Eles ganham espaço na mídia não por terem modelitos, mas pelas afirmações taxativas que passam uma segurança que não existe.

P: Mas afirmações taxativas que estariam embasadas pela ciência econômica... 
LN: Não tem ciência econômica...

\section{P: Mas é um discurso embasado em uma ciência, e é isso que o jornalista acaba comprando...}

LN: Isso... vou te dar um exemplo da inflação da jabuticaba do (economista e um dos pais do Plano Real) Pérsio Arida. O Pérsio, que é um cara brilhante, mas parou de pensar economia há muitos anos... Daí ele ganha um prêmio de economista do ano, da Ordem dos Economistas, que foi uma manipulação...

\section{P: Faz pouco tempo, não faz?}

LN: Quatro anos... mas se ele ganhasse pelo conjunto da obra tudo bem, mas pelo que ele fez naquele ano, ele não fez nada, e ele precisava de uma coisa nova... então ele vem com a tal da inflação da jabuticaba. Se no Brasil a taxa de juros real, juros menos inflação, fica abaixo de 8\%, dá inflação. Eu fiz uma coluna caçoando dele. Ele ficou ofendido, eu falei “Pérsio, vamos almoçar aí você me explica isso aî”. No almoço eu falei: “-Pérsio, eu queria que você me explicasse, não do ponto de vista teórico, mas que você me explicasse o que se passa na cabeça do cara que marca preço para justificar essa correlação que você faz.”. “Numa economia cartelizada, o produtor olha a perspectiva de inflação futura, compara com a taxa de juros e, se for abaixo de $8 \%$, ele reajusta preço". Falei: "-Se você me apresentar um cara que proceda assim na economia real, você ganha o Nobel”. Ora, as pessoas marcam preço assim, se acha de tem mercado, sobe o preço. Se você quer conquistar "market share", diminui o preço. Se há competição e choque de custo, ele assimila, absorve esse choque de preço. Isso aí são princípios básicos da economia que esses caras erradicaram. Erradicaram para quê? Para poder justificar essas posições... é por isso que 
todo jornalista, se ele fosse entrevistar um economista, tinha que fazer pergunta básica. “Por quê? Explique a correlação?”.

\section{P: Só "por que” já seria suficiente?}

LN: A correlação. Ele tem que saber fazer pergunta. Eu lembro uma vez, o Octavio... em 2002... ele falou "-Se não tiver ajuste fiscal, o gasto público não leva ao crescimento, tem que aumentar juros”. Dei um cacete nele. Marcamos de almoçar. Eu falei: “-Octavio, deixa eu te falar uma coisa: por que o ajuste fiscal leva a crescimento?" Tem razões, mas eu queria saber da cabeça dele. "-Não, porque daí você tem um gasto virtuoso". “-Octavio, imagine o seguinte: eu tenho $\mathrm{R} \$ 1$ milhão por mês, sou o prefeito de uma cidade. Eu tenho duas alternativas: pagar juro elevado ou pagar funcionário relapso. $\mathrm{O}$ que é que impacta mais a economia? Funcionário relapso. Quando ele vai comprar a geladeira dele, o cara não vai perguntar se o dinheiro é virtuoso ou não.” Você já não tinha nenhuma relação causal. É evidente que ele não pode desperdiçar com funcionário relapso, são outros quinhentos, você vai discutir, mas discutir macroeconomicamente, dizer que o dinheiro gasto... você pega o dinheiro do funcionalismo. O dinheiro do Bolsa-Família... É anticíclico. Vai gastar esse dinheiro. Esse dinheiro vai pra onde? Para o setor privado. Então como é que você vai dizer que o aumento do salário mínimo, o aumento do Bolsa-Família, o aumento do funcionalismo vão comprometer o crescimento da economia? Essas relações aí é que o jornalista tem vergonha de perguntar.

\section{P: Tem vergonha?}

LN: Tem. E os caras têm defesas, né? A defesa deles é fazer um ar superior: "-Nossa, é tão óbvio isso". 


\section{P: O apelido do Octavio de Barros é “God” nas redações, de tão superior que ele é.}

LN: Ele? Um pouquinho antes de estourar a crise internacional ele fez uma apresentação da Fiesp (Federação das Indústrias do Estado de São Paulo) que foi a coisa mais vexaminosa. Eu faço parte do Conselho de Economia lá. Ele até me chamou, no fim de semana anterior, me convidou pra tomar um chope, discutimos economia. Eu falei: “-Octavio já até sei por que você me convidou para um chope, você quer fazer "hedge" de crítica, você não quer que eu critique nada”. "-Isso mesmo, eu não gosto de bater boca, prefiro discutir aqui...”. Ele fez uma apresentação cretina, dizendo que o mundo era aquele mesmo, que o Brasil tinha que se conformar com o câmbio baixo... Provou por A mais B que a situação mundial era irreversível. Mas deu um quebra pau, porque o pessoal tem uma noção mínima de economia. Daí eu saio da reunião "Ô, Octavio, quer dizer que aquele paraíso seu já estourou?" "-Ué, até o (ex-assessor do Tesouro dos Estados Unidos e renomado professor de economia Nouriel) Roubini erra, por que eu não posso errar?" O problema é que esse erros aí ...você joga o erro agora... Quer dizer, esses erros aí, o cara fala um negócio errado agora, você só vai poder comprovar daqui um ano. Como é que faz? Eu, em 95, tive uma baita discussão, dizendo que aquela taxa de juros ia levar à maior inadimplência da história. Três meses levando pancada. A sorte minha é que estava um negócio tão violento que depois de três meses caiu a ficha e o próprio Fernando Henrique admitiu que vinha uma crise brava pela frente. Crítica de quem? Do (jornalista) Gilberto Dimenstein. Ele estava em Brasília, o (Pedro) Malan alimentava ele de respostas. Daí ele mais o Marcio Moreira Alves me acusando de ser lobista da Fiesp, lobista do (investidor-especulador do mercado financeiro) Naji Nahas. Foram criando esse tipo de desqualificação. Só que pra toda cidade do interior que eu ia, estava tudo quebrado. Então você olhava: “-Se todo o lugar que eu 
vou está quebrado, vai chegar uma hora que vai chegar na capital”. Nós fomos numa reunião em maio na Folha, eu falei: “-Seu Frias, vem uma quebradeira sem tamanho...”“ “Não, o PIB ao invés de crescer 6\%, o Malan me disse, vai crescer só 5\%”. “-Pega o mapa do Brasil e escolhe dez cidades do interior. Liga e pergunta como está lá..." À noite ele me ligou, eu estava em Nova Iguaçu. “-Tá feia a situação, tá tensa...” Mas como você tem uma cobertura da mídia só paulista, Rio, de mercado financeiro, e Brasília, então esses sinais que vêm da economia você não recebe. Os departamentos econômicos dos bancos, que têm uma enxurrada de dados, não têm essas percepções. Trazem a explicação que mais interessa aos bancos.

\section{P: A imprensa reflete essa análise que vem dos departamentos econômicos, mas o governo também a compra...}

LN: Compra, o governo pode até não acreditar, mas acaba se curvando a essa questão. Se o mercado fica nervoso e o câmbio começa a variar, você cria instabilidade em todo o sistema econômico e político brasileiro, então você ficou refém disso aí, pô. Se o câmbio subir, a inflação volta, voltaremos aos anos 80. Mas explode o câmbio três meses depois, a inflação continua sob controle e o País, crescendo.

\section{P: O senhor foi muito procurado por economistas de bancos, por assessores de imprensa? Como é que a sua relação com eles aconteceu?}

LN: Em 90, 91, 92, 93, a minha posição nunca foi de defesa do modelo dos anos 80, achei que cumpriu uma função e tínhamos que partir para um outro modelo... tinha de haver privatização, dentro de uma outra lógica, não dessa lógica que foi empregada aí... Agora, a minha relação com departamentos econômicos... Eu tive uma guerra muito pesada com o 
pessoal do governo na gestão do Gustavo Franco, no Banco Central (primeiro mandato de Fernando Henrique Cardoso). Se você pegar minhas colunas do Plano Real até 99, eram de críticas pesadas, mas eles respeitavam. Tinha argumentos, eles não me viam como incendiário... Você tem uma geração mais recente, de 2002 em diante, que são esses “cabeças-de-planilha” que pegaram um modelito para uma economia em equilíbrio, essa geração Alexandre já é muito mais despreparada do ponto de vista de visão histórica, do ponto de vista de visão sociológica, aquela geração do Real, o André (Lara Resende) e outros... meu livro mostra que aquela depreciação do Real foi para jogadas em mercado futuro de câmbio. Era um outro padrão. Era um pessoal com uma visão histórica, uma cultura muito mais ampla do que os meros modelos matemáticos. Então essa arrogância que é muito mais desse pessoal do segundo time, que chega em 2002, 2003, mas uma parte só. Nós tínhamos reuniões periódicas aqui com pessoal de mercado e da economia real. Era uma discussão respeitosa. Não tinha esse assédio. Quem fazia essa ideologia, esse assédio era o Natan (Blanche). Ele é um grande cara, ele ficou de mal de mim depois que bati muito no Mailson. A Tendências era manipuladora mesmo, e algumas pessoas que surgiram no mercado surgiam muito mais individualmente. Você tinha essa ideologia difusa que dizia o seguinte: “-Quem fala isso é atrasado, não conhece nada de economia, quem fala isso conhece". Não teve esse assédio...

\section{P: O senhor vê banalização na análise econômica que aparece na imprensa?}

LN: A banalização é você fazer a projeção em cima do momento atual. Você olha para cima, está sol, você fala “-Vai fazer sol hoje”. O noticiário está totalmente banalizado. Pega o noticiário com a apreciação do câmbio, pega a maneira como o pessoal analisava a apreciação do câmbio. De dezembro de 2007 até meados de 2008, você pega as próprias 
análises do Banco Central, é aquilo que eu falo de falta de visão de conjunto. O Banco Central fala o seguinte: está tendo uma tendência de aumento de déficit externo que vai exigir financiamento. Você tem lá o departamento econômico levantando todos os pontos e depois você tem lá o Copom, o pessoal lá do departamento de Metas Inflacionárias analisando conjunto. Então, o Banco Central diria numa parte lá: “-O Brasil vai precisar cada vez mais de financiamento externo" e depois dizia o seguinte: "-Segundo semestre a tendência é piorarem as condições de financiamento externo". Pô, você juntava as duas partes e tinha uma crise, daí quando você tem as conclusões lá eles ignoravam os dois fatos. A situação está tranquila, a apreciação do câmbio está sendo boa para a inflação, ou seja, há incapacidade da imprensa de pegar no próprio relatório do Banco Central os elementos para comprovar que a conclusão era errada.

b) A entrevista a seguir foi realizada com ex-assessor de imprensa de um grande banco brasileiro privado (instituição identificada como Y), objetivando mostrar como atua a área de comunicação de bancos em relação aos jornalistas. O profissional preferiu falar na condição de anonimato, alegando questões éticas, embora tenha permitido a gravação da entrevista. O profissional foi identificado pela letra X. Depois de trabalhar anos em redação na área de economia (Estadão, revista Exame e Folha), X tornou-se gerente de comunicação do banco Y em 1993, onde ficou até 1998, e implantou o departamento de assuntos corporativos. Também atuou em uma instituição menor, coordenando um site de finanças pessoas. Atualmente, com 16 
anos de profissão, tem a própria empresa de assessoria, que atende majoritariamente associações empresariais. Depoimento concedido em agosto de 2008.

\section{Pesquisadora: Quais os critérios para um profissional de imprensa trabalhar como assessor de comunicação de um banco?}

X: Eu acho que cada banco é um banco e cada um tem culturas diferentes. Um Bradesco é uma cultura, um Unibanco é outra, um Itaú é outra, um tem uma agressividade maior que o outro no discurso, na forma de lidar com a imprensa. No Y, os diretores são muito reservados, não fazem questão de mostrar que trabalham em um banco poderoso. E também acho que em função dessas culturas diferentes, as exigências que os bancos fazem quando colocam um profissional lá dentro também é muito diferente. No banco onde eu trabalhei tinha muito de falar uma coisa assim "-Esse jornalista é confiável, esse não é", então você dividia o jornalista em duas classes...

\section{P: Mas o que define se o jornalista é confiável ou não?}

X: O jornalista confiável em geral era mais maduro profissionalmente, que não ficava lançando coisas que poderiam mexer com o mercado de alguma maneira, com bolsa, com ação. Era o jornalista que tinha cuidado com a informação que ele leva a público. $\mathrm{O}$ jornalista não confiável é o jornalista que gosta do furo a qualquer preço. Eu entendia que era essa a distinção que eles faziam.

\section{P: E quem definia o jornalista confiável?}


$\mathbf{X}$ : Você fica cinco anos num banco, você sabe. A direção acompanha, eles conhecem os jornalistas. Você pega um banco grande, são poucos os jornalistas que cobrem isso, que conseguem falar com a direção. $\mathrm{O}$ banco onde eu trabalhava recebia duas mil ligações por mês, mas tudo parava na assessoria, me passavam e pouquíssimos jornalistas tinham acesso à direção. São sempre os mesmos.

P: O Y tem departamentos de economia. Os jornalistas falavam com os economistas dessa área?

$\mathbf{X}$ : Raramente esses analistas eram autorizados a falar com a imprensa. Quem falava era o vice-presidente.

\section{P: Por que um banco grande só deixava a vice-presidência falar? Não dava para fazer um media training com outras áreas?}

X: Não, era muito centralizado. Ninguém falava lá sem falar com a assessoria. Abaixo do vice-presidente você tinha uns quatro diretores executivos, que eram autorizados a falar. Estes mesmos eles preferiam passar para o vice-presidente. Porque lá, eu acho que no Itaú também é assim, eles não gostam de aparecer em nenhuma situação. Tem umas coisas bem curiosas, eu lembro muito disso, que você tem a impressão que o banco engana o jornalista. "-Ah, desviou o cara da notícia". Eles têm uma ética própria e que é muito interessante de você sacar. Eu fiquei cinco anos no Y e eu nunca menti para um jornalista. Mas você tinha códigos com a executiva.

\section{P: Em que mentiria para jornalistas?}


X: Por exemplo, jornalista ligou lá e falou assim: "-X, eu estou com uma informação aqui que o banco vai comprar tantos por cento de participação na Vale (maior mineradora brasileira, antes chamada de Companhia Vale do Rio Doce), você pode ver isso pra mim?" E alguns jornalistas já tinham esse código comigo. Eu ligava para a direção e a direção falava "Isso é verdade, mas a gente não pode confirmar, mas também não vai mentir". Era um código que você estabelecia com o jornalista que você conhecia melhor. O cara já sabia, se eu falava assim "-O banco não confirma". Eles falavam assim "-Mas desmente?" "-Não". Aí eles publicavam. Porque era um código, a gente não podia confirmar que a coisa era verdade, mas a gente não mentia. Eu posso ter omitido alguma coisa, mas nunca falei "Imagina, isso não procede". A própria diretoria fazia essa distinção entre o jornalista confiável e o não confiável.

\section{P: O que é esse departamento de assuntos corporativos que o senhor criou?}

$\mathbf{X}$ : Na época que eu entrei lá, eles não tinham política nenhuma de relacionamento com a imprensa, não atendiam, era uma coisa horrível. Eu fui para melhorar a imagem deles com a imprensa. Era esse o objetivo deles.

\section{P: Se o banco era tão fechado, por que queria melhorar a imagem com a imprensa?}

X: Queria melhorar, mas não queria se abrir mais não. A ideia era assim, na cabeça deles, se eles tivessem uma pessoa que fosse jornalista e que pensasse como jornalista, essa pessoa ia conseguir administrar esse relacionamento com a imprensa. Eles não precisavam se expor mais, só o fato de ter um jornalista que falasse a mesma linguagem do outro jornalista, isso já acabava criando um ambiente favorável para que diminuísse essa resistência. A relação com a imprensa era péssima, subordinada ao marketing. $\mathrm{O}$ cara falava 
“-quero falar com o presidente sobre não sei qual assunto", até isso chegar ao presidente, se chegasse... O próprio marketing avaliava se valia a pena ou não, daí chegava o dia seguinte, saia uma merda no jornal. O departamento que criei começou a cuidar da comunicação como um todo e deu um direcionamento ao trabalho dos jornalistas. Eles ligavam para o banco, passava pra mim, mais tarde para a equipe, mas aí a gente atendia, levava o assunto, agilizava, estava ali praquilo.

\section{P: Como se fazia a filtragem das demandas, era entre o confiável e o não confiável?}

X: Todos os assuntos eram levados para o vice-presidente, que cuidava da área de crédito, do mercado imobiliário, mas muitas vezes eu já levava com a solução. "-Olha, a agência não sei de onde foi assaltada, eu orientei o gerente a fazer tal coisa, tudo bem? Tem outra orientação?" Na verdade eu influenciava muito na decisão de falar ou não. Eu tinha uma influência grande nesse momento. Porque eu não posso pegar 500 pedidos de entrevista por dia porque senão o cara não vai trabalhar, vai ficar atendendo jornalista, o trabalho dele vai ser esse, só. Então eu fazia uma triagem. No começo eu me reportava ao diretor de marketing. Depois, quando eles foram confiando, o diretor de marketing foi saindo e eu fui subindo.

\section{P: A assessoria deixava jornalista sem resposta?}

X: Nunca. Essa era uma orientação que eu tive, desde o começo. Jornalista não pode ficar sem resposta. Ele liga lá e fala assim "-Eu queria fazer uma matéria sobre redução de crédito, juros..." Aí eu atendia, olhava, voltava, e dizia “-Não vai rolar porque o diretor da área não pode falar.” Isso eu considero respondido. 


\section{P: Havia um filtro?}

X: Tinha coisa que a gente filtrava também. Diário Popular... Interessava falar sobre esse assunto? Não interessa, então vamos priorizar outro jornal. Aí chegava no final do ano, caderneta de poupança, $13^{\circ}$, alguma coisa assim, tinha uma meta de que aumentasse o depósito lá, daí eu ia no Diário Popular. Eu priorizava aquilo como um veículo dentro da estratégia de aumentar captação de poupança.

\section{P: A assessoria divulgava dados, como projeção de PIB? O Y tem hoje o boletim de análise que eles mandam para os clientes e que soltam para jornalistas também?}

$\mathbf{X}$ : Não fazia, naquela época nem tinha interesse em fazer isso, uma coisa que eles não queriam de jeito nenhum era fazer projeção de nada.

\section{P: Quantos jornalistas estavam na lista dos confiáveis? Ou também se media o confiável pelo veículo que estava ligando?}

X: Esse negócio de jornalista confiável e não confiável é assim, você pega os grandes jornais de São Paulo e Rio, jornal de São Paulo você tem no máximo três jornais grandes, uma pessoa em cada jornal, três, quatro jornalistas em São Paulo e quatro no Rio. Brasília era menos, são caras mais agressivos, que gostavam de dar furo, de manchetar. Em geral você tem duas categorias de jornalistas, que eu não consigo dizer se são erradas, o confiável e o não-confiável. Como jornalista, eu jamais ia admitir essa divisão, porque o jornalista tem de trabalhar. Mas eu entendia o que os diretores falavam. É o cara que tem a responsabilidade no trato da informação e o cara que não tem. $\mathrm{O}$ cara que vai porque a ambição dele em aparecer é maior... Entendeu? Aí você fala assim “-Bom, então vamos discutir essa responsabilidade no trato da informação". Realmente, aí você entra numa coisa 
subjetiva. O que é essa responsabilidade? Essa responsabilidade é pra não colocar o banco numa fria? Pode ser. Daí se você coloca o banco numa fria, o efeito é sistêmico.

Por exemplo, você sabe que um banco está quebrando. E aí? Você vai dar essa notícia ou não vai dar? É uma decisão complicada, tem consequências graves até para os cotistas. É desse jeito que é colocado, nisso eu acho mesmo, acho que tem um grupo de jornalistas bem informado, quanto mais informado ele é, mais maduro ele é nesse aspecto do tratamento da informação. Agora, a neutralidade fica comprometida, tem um envolvimento, acho que o jornalista que cobre a área de finanças, eu sentia isso às vezes, eles eram seduzidos.

\section{P: Pelo quê?}

$\mathbf{X}$ : Pelo poder dos bancos. Conseguir falar com um presidente do banco, com o vicepresidente, é uma coisa assim de status, eles se deixavam muito seduzir pela coisa do poder. Eu acho que os bancos percebem isso, os executivos dos bancos têm muita clareza sobre isso.

P: E isso permite algum tipo de troca entre essas partes? Eu te dou a entrevista, mas eu falo o que eu quero... Tudo muito implicitamente, nunca falado...

$\mathbf{X}$ : Isso existe, não só no setor financeiro, isso existe mesmo, tipo eu te dou uma informação hoje, e daqui a um tempo, “-Mas eu passei aquela informação legal pro cara, tenta vender isso pra ele porque eu acho que ele vai dar em agradecimento”. Isso tem muito.

\section{P: Quando trabalhava no banco, dava media training (orientação de executivos para} falar com a imprensa)? 
X: Para o pessoal do banco, não, mas eu orientava entrevista. Pegava a pauta, em todos os casos, por telefone também, eu sempre dava todas as indicações, e lá tinha muito o que a gente chamava de armadilha, a pessoa chegava lá: “-É uma matéria sobre não sei o quê", quando ia ver, colocava o cara numa fria desgraçada. Aí é que você vai aprendendo quem é quem. Não quem é quem no sentido de ser ruim. Assim, “-Com a Paula é preciso tomar cuidado, porque ela fala que é uma coisa, vai lá e é outra, ela só fala que é aquela coisa pra conseguir chegar". Você vai pegando a malandragem. Eu chegava pro vice-presidente, falava "-Fulano ligou", eles tinham que saber tudo, mesmo que fosse um diretor que falasse. “-É a Paula, ela está falando que vai fazer uma matéria sobre tal assunto, eu acho que não é sobre esse assunto, acho que ela vai falar sobre tal assunto, que está usando isso como pretexto porque ela vai entrar naquele assunto do precatório porque ela está acompanhando esse assunto todos os dias, o senhor quer falar?"

\section{P: E media training, o senhor dá para os clientes de sua assessoria?}

X: Super comum. Eu fiz um orçamento para um dia inteiro de media training para dez pessoas, esse não é o melhor media training, mas saiu por $\mathrm{R} \$ 15$ mil. Em geral, um jornalista que vai dar o treinamento tem que ter um carisma, não é qualquer um, eu não sou uma pessoa própria pra fazer isso. A pessoa tem de falar a linguagem do executivo, brincar, vir com a própria equipe. Os meus clientes, acho que todos já fizeram. Porque eu trabalho com muita associação, e os empresários vêem da iniciativa privada, grandes empresas, onde recebem treinamento. 
c) Entrevistas em economistas de bancos e banqueiros sobre financeirização e relacionamento com a imprensa.

1) Boris Tabacof foi presidente dos bancos Safra (1970 a 1975) e Banespa (1989) e dirigiu a Anbid (Associação Brasileira de Bancos de Investimento) no fim dos anos 1970. Entrevista concedida em novembro de 2006.

\section{Pesquisadora: Como vê a comunicação do setor financeiro?}

Boris Tabacof: $\mathrm{O}$ setor financeiro não se comunica institucionalmente ou sobre políticas via cada banco individualmente. Você vê que rarissimamente os banqueiros quando falam de política, falam pessoalmente. O Olavo Setúbal (Itaú), uma figura muito importante nesse processo político, tomava o cuidado de nunca falar em nome do banco dele. Um exemplo mais recente é o Banco Votorantim, criado há muito pouco tempo. Hoje, é um dos bancos mais importantes do País, e o principal acionista dele, Antonio Ermírio de Moraes, continua numa posição como se nada tivesse a ver com o setor, embora boa parte dos bons resultados do Grupo Votorantim, que é predominantemente um grupo industrial, se dê pelo desempenho do banco. Os bancos hoje fazem seus lobbies via Febraban (Federação Brasileira de Bancos). O (então) atual presidente, Fabio Barbosa (na época presidente do ABN Amro no Brasil), é uma figura muito conhecida, de líder empresarial, um executivo e não um herdeiro familiar.

Outro exemplo é a Anbid. Essa entidade tinha uma atuação muito forte. Eu diria que o setor bancário lembraria um iceberg. A parte visível, a parte pública, que tem a ver com a 
comunicação, é a parte acima da linha d’água. Abaixo disso, os icebergs têm uma massa enorme, que no caso seria uma ação política muito intensa.

\section{P: ... que é o que a Febraban e a própria Anbid fazem?}

BT: Não, o que eu estou chamando de informal é um diálogo permanente. Tem a comunicação institucional, visível, que tem cada vez mais a ver com a participação de economistas da melhor qualidade que eles recrutam, e esses representantes aparecem muito na mídia. Tem as instituições, e tem toda a parte que eu diria comunicação informal política.

\section{P: Como é essa comunicação informal política?}

BT: A comunicação política informal é um diálogo intenso e constante com o setor financeiro regulador, basicamente o Banco Central e o Ministério da Fazenda. Observe que não considero que haja uma ligação menos nobre, coisas secretas, misteriosas, não é isso, não. Pelo que eu sei, o sistema bancário tem um diálogo dinâmico e muito constante, e muito competente, e aí eu acho que é comunicação. Eles estão constantemente se falando, dialogando, propondo ideias. A representante dos bancos é a Febraban, e é ela que prepara todos os trabalhos, estudos, que obviamente são alimentados pelos próprios bancos. A Febraban tem uma estrutura profissional forte, como tem a Anbid (Associação Nacional dos Bancos de Investimento), como tem a Apimec (Associação dos Analistas e Profissionais de Investimento do Mercado de Capitais). Enfim, a capacidade do sistema bancário de promover legitimamente os seus interesses é muito forte.

\section{P: Como o senhor acha que os bancos dominaram o discurso econômico nos jornais?}


BT: Depois do Plano Real, esses economistas que são muito competentes, que são chamados de "pais do Real", conquistaram vários postos no governo, no BC, Ministério da Fazenda e entidades correlatas, como Banco do Brasil e BNDES. Como são pessoas muito competentes, transformaram reivindicações de estrito interesse de um determinado segmento, em assunto do maior interesse nacional...

\section{P: Como eles fizeram isso?}

BT: É um instrumento da ideologia. O que existe é uma crença total de que o mercado tudo resolve. Se alguém achar que pode haver um grau de intervenção maior no sistema financeiro ou no sistema industrial, é execrado. Aí entram também os interesses do sistema financeiro, que trabalha para ter cada vez menos regulação. E esses economistas do livre mercado estão uma hora no governo, hora no setor bancário, você pode identificá-los, eu não quero dizer o nome. É só ver os que estavam no sistema bancário e estiveram na área pública e que hoje estão em um negócio que cresceu muito, que não são entidades financeiras, mas empresas de gestão de fundos. Pega-se dinheiro barato em dólar, repassase para o mercado financeiro com juros e receitas altíssimos, fazendo arbitragem. Isso, fazem até hoje.

Eu não gostaria de dar minhas palavras como palavras de suspeita ou de dúvida, todos agiram estritamente de modo legal, eles aproveitaram condições sistêmicas, legais, e de acesso à informação. Mas essa gente toda, o período foi exatamente o período do Plano Real. E continua com o Lula. De onde vem a raiz ideológica do pensamento único? Muitos deles estudaram, são muito fortes em pós-graduação, na Universidade de Chicago (EUA). É o centro mundial do pensamento único de que o mercado resolve tudo. O sistema financeiro, quanto menos regulação melhor, por conta do crescimento das bolsas de 
valores, dos mercados de câmbio, juros, as operações arriscadas de derivativos. Pra entender, eu aconselharia você a pensar não só no sistema bancário. Abra a sua ideia em todo o sistema financeiro, aos Goldman Sachs da vida, todos esses bancos de investimento, o JP Morgan tem banco comercial e tem banco de investimento. No Brasil, o sistema financeiro continua concentrado nos "bancões comerciais". Mas no mundo, há muitos bancos só de gestão de investimentos, que também aportaram no Brasil.

Veja um exemplo interessante: a Lei de Falências. O pessoal do sistema bancário/financeiro conseguiu transformar a Lei de Falências, que beneficia a eles como credores, numa lei do maior interesse da sociedade brasileira. Essa lei que foi aprovada facilita a execução das dívidas. Aqui nesta mesa, nesta mesa (numa sala da Federação das Indústrias do Estado de São Paulo - Fiesp), veio o presidente da Febraban pedir apoio da indústria para a Lei de Falência. Mas eles foram tão enfáticos, que eu disse "-Ô, fulano, aqui é a casa dos devedores, não é a casa dos credores”. Eles têm teses complexas, a que está hoje é: redução dos compulsórios. Virou uma causa nacional. E tudo isso é feito de uma maneira competente, é isso que os difere dos outros setores da sociedade. A competência técnica, profissional dos que se comunicam pelo sistema bancário, seja publicamente, seja institucionalmente. Eles conseguem pegar temas de interesse dos bancos e transformar em causas nacionais.

São altamente profissionais, dispõem de enormes recursos. A primeira leva de profissionais de bancos, que foi a minha (o entrevistado tem perto de 70 anos) e veio do sistema público, ficou para trás. O momento da mudança tem a ver mais exatamente com o Plano Real, com a estabilidade, com o poder cada vez maior do Banco Central.

Você sabe que a Bovespa (Bolsa de Valores de São Paulo) e a BM\&F (Bolsa Mercantil \& de Futuros - ambas foram fundidas em 2008, formando a BM\&FBovespa) são entidades 
riquíssimas. O (ex-presidente da Bovespa Raymundo) Magliano anda na praia fazendo propaganda da Bolsa, da bolsa popular, quer dizer, eles dão uma prioridade enorme à comunicação. Quem defende as teses do sistema financeiro são economistas do mais alto nível, pessoas que têm uma penetração social e intelectual forte, inclusive na academia, e dispõem obviamente de um prestígio nobre com a mídia, até porque os bancos são grandes anunciantes.

\section{P: Que teses são essas?}

BT: A política principal do pensamento hegemônico coincide com o poderio crescente do sistema financeiro formal. Com essa massa enorme de recursos que transitam aí pelo planeta e que fora objetos de montagem de instrumentos como derivativos, hedges - e que os bancos brasileiros não chegaram a entrar muito nisso, aqui isso é muito incipiente, mas nos Estados Unidos, na Europa, é coisa gigante. Todo pensamento gira em torno da desregulamentação, do poder do mercado em regular todos os setores da sociedade sozinho. Um dia eu analisava a relação entre as receitas dos bancos e as teses políticas deles. Era pegar a demonstração de resultados que eles tinham que publicar e separar, por exemplo, receitas de juros...então você poderia ver, por exemplo, operações de tesouraria, essas precisam de arbitragem de juros Selic, é o rendimento mínimo de boa parte: comprar títulos do governo. Você podia examinar participação de tarifas, receita de câmbio, receitas de operações financeiras.

\section{P: Como o senhor vê o papel dos departamentos econômico dos bancos?}

BT: Isso é um bom exemplo. É departamento de pesquisas e estudos econômicos. Todos têm isso. Serve internamente para orientação dos negócios do banco. Por exemplo, 
identifica tendências de setores que estão crescendo e atividades que estão melhorando mais. Vejamos o segmento imobiliário, esses estudos deles têm a parte macro do setor, mas vão também a análises mais detalhadas de segmentos do mercado que representam oportunidades de negócios. Isso aqui é distribuído para um mailing interno e externo, de clientes. Os jornalistas recebem. O (economista) Otávio de Barros (ex-BBA e atual Bradesco) foi um dos profissionais que mais desenvolveu o papel dos departamentos econômicos, com grandes equipes e inúmeras pesquisas e projeções.

Esses economistas conseguem fazer uma convergência de teses. Quero dizer, têm uma posição olímpica, de querer o bem do Brasil, o que faz com que tornem suas teses de interesse de toda a sociedade.

Toda a história dos bancos se mostrarem acima dessa história de juros, eles chegam ao cúmulo até de criticar, mas eles é que se beneficiem dos juros altos. De novo a Lei de Falências: nos últimos anos eles a usam para justificar o juro alto, o spread, que é o verdadeiro problema para o tomador de crédito, mas do qual o banco se beneficia muito. $\mathrm{O}$ problema é que eles conseguem desviar a atenção do verdadeiro problema do custo do dinheiro, que é o spread que eles cobram. Então eles atacam a Selic, mas o problema não é a Selic, mas o spread. Eles dizem: “-O spread resulta da inadimplência, então a Lei da Falência vai melhorar muito isso, nós vamos conseguir cobrar melhor as dívidas dos inadimplentes”. A nova Lei de Falências está aí, mas o spread não diminuiu nadinha...E tem outras coisas do interesse deles que eles fazem parecer de interesse nacional: o tal crédito positivo que eles estão defendendo agora, redução ao mínimo do depósito compulsório, a tese dos créditos direcionados...No meu tempo de banqueiro no Safra, sabe quanto era o spread? O banco Safra era um banco careiro, que estava começando, o spread 
era $6 \%$. Nos grandes bancos, emprestavam dinheiro a 4,5\% de spread entre o que ele pagava na captação e aplicava para os clientes.

2) A pesquisadora solicitou entrevista com o economista $Z$ porque ele foi um dos primeiros profissionais de bancos a aparecer na imprensa para falar de assuntos de macroeconomia, logo no início dos anos 1990. Suas entrevistas foram ainda mais frequentes após o Plano Real, de 1994. Z tem mestrado pela Universidade de Paris I-Sorbonne e doutoramento pela Universidade de Paris X. Foi assessor duas vezes do Ministério da Fazenda e professor de Economia Internacional da Universidade de Campinas, além de participar como assessor de uma série de instituições, entre elas a UNCTAD (Conferência das Nações Unidas para o Comércio e o Desenvolvimento). Quando economista-chefe de um banco estrangeiro no Brasil, criou um departamento econômico expressivo, com forte trabalho na área de projeções. Por conta da divulgação desse trabalho e de sua disponibilidade, $Z$ passou a aparecer cada vez mais no noticiário, inclusive no televisivo. Quando em janeiro de 2003 esse banco estrangeiro foi comprado por um grande banco brasileiro (aqui chamado de $\mathrm{K}$ ), $\mathrm{Z}$ deu novo papel ao departamento econômico incipiente do banco $\mathrm{K}$, produzindo, inclusive, boletins diários de análises para clientes pagantes. Esses boletins chegam diariamente à imprensa. $\mathrm{Z}$ faz parte da diretoria do banco, mas já não fala tanto com os jornalistas. Aceitou dar entrevista sobre seu relacionamento com a imprensa, mas para surpresa da pesquisadora, na hora do depoimento ele disse que não queria falar nada gravado e nem anotado por 
completo. Aceitou apenas que fosse anotado e reproduzido no trabalho algumas respostas. Depoimento concedido em março de 2007:

\section{P: Por que o senhor não quer gravar entrevista?}

Z: Porque sou uma pessoa muito conhecida, e o banco em que trabalho não gosta de ver seu nome ou de seus funcionários publicados.

\section{P: Mas só gostaríamos de saber como é seu relacionamento com a imprensa? \\ Z: Entendo, mas como falei tenho de respeitar as normas do banco.}

P: Então, me comprometo a não publicar seu nome nem do banco ...

$\mathbf{Z}$ : Certo, mas não quero gravar entrevista

\section{P: Estou anotando...}

Z: Estou vendo, mas só vou deixar você anotar algumas coisas.

\section{P: Conte como foi sua inserção na imprensa}

$\mathbf{Z}$ : Os jornalistas começaram a me procurar porque eu era um dos dirigentes da Sobeet (Sociedade Brasileira de Estudos de Empresas Transnacionais e da Globalização Econômica, fundada em 1994) e falava de investimentos estrangeiros no Brasil, um assunto que sempre rendia matéria para os jornalistas. A Sobeet soltava boletins mensais comentando o tema, esses boletins chegavam aos jornalistas, e eu era procurado. Eu já 
trabalhava em um banco estrangeiro importante e também tinha uma carreira acadêmica. Foi $\operatorname{assim} .$.

\section{P: A Sobeet tinha assessoria de imprensa?}

Z: Não que eu me lembre, sempre foi a secretária que cuidou da lista de mailing. A entidade ficou conhecida porque tinha um trabalho importante de análise de investimento direto estrangeiro.

P: Mas, como o senhor mesmo disse, a imprensa recebia esses boletins. Significa que havia um trabalho de divulgação...

$\mathbf{Z}$ : Sim, era um trabalho de divulgação que chegava aos jornalistas, mas sem assessoria.

P: Quando trabalhava no banco estrangeiro, mais ou menos na época em que estava na direção da Sobeet, o senhor atendia aos jornalistas também como economista-chefe do banco. O banco tinha assessoria? Ela encaminhava entrevistas?

Z: O banco tinha assessoria, sim. Mas nunca precisei dela para me apresentar a nenhum jornalista. Eu já era conhecido. Às vezes a área de imprensa encaminhava alguma demanda e eu avaliava se daria ou não entrevista, mas eles nunca interferiram no meu trabalho.

P: O senhor já fez media training?

Z: Nunca precisei fazer

P: Os boletins de análise econômica de sua equipe no banco $K$ chegam à imprensa ao mesmo tempo em que chegam para os clientes. $O$ senhor não acha que mandar para a 
imprensa um material que seria exclusivo de clientes é uma forma de ajudar na pauta do noticiário, afinal o banco K é um dos mais importantes do Brasil e o que ele pensa tem peso?

Z: Não vejo qualquer problema nisso, não sou eu quem mando. Talvez a assessoria mande...

P: Mas os boletins mostram aos jornalistas a opinião do banco K sobre fundamentos e medidas econômicas. Isso tem repercussão...

Z: Sem dúvidas, mas minha equipe não fala com os jornalistas, eles não dão entrevistas. A não ser que a assessoria de imprensa autorize, mas ela é muito rigorosa. Eu já dei muita entrevista, mas hoje só falo com alguns pouquíssimos jornalistas.

\section{P: Quais?}

Z: Falo com o Fernando Dantas, do Estadão (sucursal do Rio de Janeiro), com o (André) Palhano, ex-Agência Estado, um pouco com o Guilherme Barros, colunista da Folha.

P: O senhor se considera um economista influente. O que fala reflete em Brasília?

Z: Sem dúvidas. Com muita frequência, sou convidado para reuniões com o governo ou para discutir coisas que eu falei via imprensa ou boletim ou para opinar sobre assuntos macroeconômicos.

P: Então o senhor é um economista de banco que influi na pauta do governo?

Z: Sem dúvida. 
P: Mas o senhor não vai lá (Brasília) defender os interesses do banco?

$\mathbf{Z}$ : Não, vou como economista que tem profundo conhecimento de economia. Mas é claro que minha visão é a mesma do banco, caso contrário eu seria um dos diretores. Sequer trabalharia lá.

P: O senhor é a favor do livre mercado, da total desregulamentação da economia, do estado mínimo?

Z: Totalmente defensor.

P: O professor e ex-ministro Delfim Netto é um crítico feroz dos economistas de bancos, porque, segundo ele, eles trabalham basicamente com projeções numéricas. Os boletins de seu banco trazem muitas projeções desse tipo. Como o senhor encara as críticas à pesquisa econômica baseada em cálculo.

Z: O professor Delfim é um mestre, o maior economista do Brasil, e eu respeito tudo o que ele fala. Não vou entrar em polêmica, mas quem critica a econometria não conhece direito essa ciência, não sabe o que fala. São instrumentos de previsibilidade importantes, necessários para qualquer empresa e até o governo fazer seus planejamentos.

3) Alexandre Schwartsman iniciou a carreira no Unibanco, no departamento econômico, mas falou com a imprensa pela primeira vez quando foi ser economista do Pão de Açúcar, 22 anos atrás, ao jornalista Fabio Paim (hoje no Estadão), sobre o plano de reestruturação da empresa. Voltou a trabalhar em bancos, de onde tira sua experiência de contato com a imprensa. Trabalhou nos bancos Indossuez, no 
BBA, foi diretor do Banco Central na gestão Henrique Meirelles do primeiro mandato do governo Luiz Inácio Lula da Silva, voltou para o setor privado no ABN-Amro e atualmente é economista-chefe do Santander para a América Latina. Entrevista concedida em março de 2007.

\section{Pesquisadora: Colocaram o senhor para falar com a imprensa logo no inicio da carreira?}

Alexandre Schwartsman: Sim, eu era totalmente júnior na equipe, mas nunca tive muita dificuldade pra me expressar e me colocaram para falar com jornalista.

\section{P: O senhor foi professor?}

AS: Fui. Não dou mais aula. Na época eu já dava aula, o primeiro curso que dei foi em 1987. Formei-me pela FGV (Fundação Getúlio Vargas) como administrador em 1984, como economista em 1986. Em 1987 eu estava começando o mestrado e no segundo semestre de 1987 eu fui dar aula na PUC, levado pelo Celso Daniel (ex-prefeito de Santo André, ex-membro da executiva nacional do Partido dos Trabalhadores, morto em 2002).

\section{P: Como foi sua passagem para o mercado financeiro?}

AS: Quando me formei, comecei trabalhando no Unibanco já no departamento econômico, recomendado pelo meu professor Geraldo Gardenalli, e fiquei lá até meados de 1986. Era época do Plano Cruzado, e o Unibanco, bem como uma série de outros bancos, estava reduzindo o tamanho do pessoal. O meu chefe na época, o Walter Brasil, sabia que o 
Gardenalli procurava alguém para trabalhar com ele no Pão de Açúcar, e eu fui. Mas eu comecei trabalhando do mercado financeiro.

P: Quando os jornalistas começaram a lhe procurar, tirando essa parte do Pão de Açúcar?

AS: Foi bem depois, foi quando eu voltei do doutorado em 1996 e fui trabalhar no banco de investimentos Indossuez, até 2001. Antes disso só me lembro de ter publicado um artigo no Estadão e dar uma entrevista para alguém na Gazeta Mercantil.

\section{P: O senhor lembra se o Indossuez tinha assessoria de imprensa?}

AS: Não logo que eu entrei, só mais tarde, mas não era para os economistas, era para o pessoal da direção do banco.

P: Independente de ter assessoria, o senhor fez media training no Indossuez?

AS: Não, fiz só quando estive no BBA, onde trabalhei de julho de 2001 a dezembro de 2002.

P: Como não tinha assessoria de imprensa, lembra-se mais ou menos como as pessoas chegavam até ao senhor? Tinham amizade, faziam encontros...

AS: Não, não tinha nada disso. Na verdade eu acho que comecei a ter uma exposição maior ainda na imprensa via Agência Estado, pela jornalista Andreia Lago, editora do $A E$ Mercado (coluna diária sobre os principais fatos que impactam o mercado financeiro, exclusiva para assinantes e distribuída pelo terminal do AE News/Broadcast, já mencionado na primeira parte deste trabalho). Eu li alguma coisa, escrevi para ela contestando uma 
informação, aí começamos a conversar mais. Apareci na Agência Estado, depois Estadão, Folha, lá por volta de 1999.

P: Que importância o senhor dá para a mídia hoje no seu trabalho? O senhor fala bastante com a imprensa. Gosta?

AS: Às vezes eu não gosto, mas faz parte do trabalho. Porque a gente trabalha numa instituição financeira de varejo, é importante manter a projeção do banco como uma instituição que tem economistas que falam, que têm o que falar. Espero que melhore a imagem do banco. Algumas coisas são temas que me interessam, porque eu não concordei com uma determinada afirmação, eu acho que ela precisa ser corrigida, aí às vezes eu tomo a iniciativa de escrever. E dessa forma eu eventualmente participo do debate público.

\section{P: O senhor disse que no BBA passou por media training... Além disso, a assessoria de imprensa lidava com o senhor?}

AS: Relativamente pouco. Eu não me lembro nem do nome da assessora de imprensa. Mas eu me lembro de ter feito lá o media training. Do BBA, voltei para o Unibanco, que é muito mais fechado para a imprensa. Apesar disso, não havia qualquer restrição. Ao contrário. A assessoria de imprensa (Unibanco) sempre trazia coisas. Uma revista em particular para quem eu não falo é a Carta Capital, por uma série de motivos, e eu me lembro que a assessora vivia insistindo para eu falar com eles. “-Com esses caras eu não falo de jeito nenhum". Mas eu me lembro de ter ido almoçar na Veja, por iniciativa deles. Vi gente da Folha, como o Márcio Aith, que foi lá no banco para conversar, enfim, não tinha nenhuma restrição. Essa minha segunda passagem pelo Unibanco foi bem curtinha. Eu fiquei de janeiro e setembro de 2003. Em setembro eu saí do Unibanco, e em novembro eu comecei 
no Banco Central. Fiquei até abril de 2006. Depois de um mês de quarentena, eu vim para cá (ABN Amro).

\section{P: A assessoria de imprensa aqui (ABN Amro) é ativa no trabalho de vocês?}

AS: Bastante, é a GWA. É terceirizada, mas de todas, é a mais ativa em termos de trazer respostas. $\mathrm{Na}$ verdade, eu tive de aprender um pouco a trabalhar com eles, porque já tinha muita gente que me ligava direto, na minha mesa. Mas eles pedem para os jornalistas passarem antes por eles, da assessoria.

\section{P: Mas o pessoal da Agência Estado geralmente liga direto...}

AS: Liga direto... Mesmo assim eu entendo que a assessoria quer falar antes com o jornalista mais no sentido de saber com quem se está falando, eles também fazem um controle...

\section{P: Mais ou menos quantas vezes por mês o senhor fala com os jornalistas?}

AS: Nossa, eu não sei. Mais de dez vezes, certamente. Depende muito da época. Tem coisas associadas ao Banco Central que saem e aí sou capaz de falar com três, quatro jornalistas no mesmo dia. A nota que saiu há duas semanas sobre a transformação do Brasil em grau de investimento foi assim. Folha, Estado, Valor, Gazeta Mercantil, um monte de gente. Na verdade tem assunto que você vai falar, repetir quatro vezes a mesma história. Às vezes me enche, mas já que você falou com um, fica um negócio meio grosso não querer falar com os outros. Mas às vezes complica mesmo, tenho de focar mais no meu trabalho, mas ao mesmo tempo tenho de atender à imprensa. 


\section{P: Atender aos jornalistas chega a atrapalhar seu trabalho?}

AS: Chega. Quando é uma vez no dia, sem problemas. Mas quando tem um negócio importante, e você está lá tentando pensar a respeito - muitas vezes eu escrevo, solto nota para os clientes... O que eu mando para cliente, mando para a imprensa. Aí, telefone tocando... você reconhece... “-Alguém puxa aí pra mim? Segura, desvia porque não tenho condição de falar agora”.

\section{P: Muitos jornalistas têm o seu celular?}

AS: Meu celular, acho que ninguém. O telefone de casa muita gente tem, porque por complicação de horário muitas vezes eu acabo passando. Mas, como regra, tem o telefone do banco, é livre, alguns ligam para a secretária, alguns perguntam "-Você pode falar agora?”. Se tenho condição de dar entrevista eu falo que tudo bem, mas alguns já saem perguntando (risos).

P: O senhor avalia que os jornalistas reproduzem fielmente o que o senhor fala? Costuma ter problemas?

AS: Muito pouco problema, não consigo lembrar agora de cabeça de uma grande distorção. Teve até um episódio, obviamente que fui eu mesmo que falei, estava ainda no BBA, eu não lembro o nome jornalista, o cara era gringo, ele perguntou alguma coisa, eu fiz uma piadinha qualquer e ele botou. Eu nem posso culpar o cara, porque fui eu que falei.

\footnotetext{
P: Em que medida os jornais são importantes para o seu trabalho? O senhor acha que de alguma forma interfere nas ações ou na agenda do governo, o que o senhor fala bate em Brasília de alguma forma?
} 
AS: Bem que eu gostaria de interferir na agenda, mas eu acho que não. O que eu falo acho que não tem muita importância do ponto de vista de formulação de política.

\section{P: E o que o senhor fala costuma refletir no próprio mercado?}

AS: Dizem que algumas vezes sim, por causa da minha experiência de Banco Central... Por exemplo, ano passado eu conversei com a Célia Froufe (Agência Estado), a gente fez uma entrevista para o Broadcast, saiu uma coisa, isso era setembro ou outubro do ano passado (2007). “-Pode subir taxa de juros em 2008?” “-Sim, há uma possibilidade.” Isso teve uma repercussão enorme, quando eu disse que iria subir, existe uma chance concreta de isso acontecer, e teve essa repercussão.

\section{P: Essa repercussão é mais no mercado de juros ou bolsa?}

AS: Mais no mercado de juros.

\section{P: Avalie de "muito produtivo" a "improdutivo" o seu contato com a imprensa.}

AS: Em geral é produtivo. Tem esse custo de enquanto eu estou dando entrevista, eu não estou pesquisando no meu trabalho. Eu não tenho grandes reclamações, não tenho caso de distorção de uma coisa que eu tenha falado. Quando eu estava no Banco Central houve distorções mais indiretamente, eu não tinha falado com jornalista, mas outra pessoa falou e aí outras repercussões, mas na minha experiência como economista de mercado, não, em geral é muito produtivo. 
d) O economista Antonio Corrêa de Lacerda, professor da Pontifícia Universidade Católica de São Paulo (PUC-SãoPaulo), é consultor de várias entidades empresariais, como a Associação Brasileira da Indústria Elétrica e Eletrônica (Abinee). No curso de pós-graduação Latu Sensu de Economia para Jornalistas da PUC-SP, Lacerda dá uma aula sobre a financeirização do noticiário econômico. Entrevista concedida em agosto de 2006.

\section{Pesquisadora: O noticiário brasileiro é financeirizado? Desde quando?}

Antonio Corrêa de Lacerda: A financeirização é um fenômeno não só brasileiro, mas mundial. O caso brasileiro tem particularidades. A gente tem um movimento na economia mundial que é forte nos anos 80, que a gente chama de financeirização da economia. Ou seja, o setor financeiro, que surgiu como um anexo do setor produtivo, financiando-o, ganhou uma dimensão própria, porque a tecnologia permitiu a integração dos mercados, o mercado financeiro se sofisticou com derivativos, com o mercado de capitais, os fundos de hedge, então isso deu uma diversificação muito grande.

\section{P: E foi a tecnologia que permitiu essa mudança?}

ACL: A tecnologia ligou os mercados online, então eles ganharam uma dimensão própria e descolada da produção. E o mercado financeiro permitiu realizar lucros muito mais rapidamente do que na atividade produtiva. Então, pós anos 1970, 1980, final do século $\mathrm{XX}$, a grande atenção se voltou para o mercado financeiro, inclusive a atenção da mídia. E no Brasil, isso também se fez presente, de uma forma muito intensa. Ao mesmo tempo em que a informação econômica se democratizou nas páginas de economia dos jornais, espaço 
na televisão, no rádio, por outro lado, o discurso financeiro dominou o debate econômico. Tudo gira em torno das finanças.

\section{P: Esse foi um movimento que partiu da mídia ou partiu do próprio mercado? Quem chegou em quem?}

ACL: As duas coisas. O mercado se sofisticou, e para se sofisticar, ele sofisticou a análise. Então os bancos, as corretoras, os fundos, montaram equipes de economistas inteiramente dispostos a atender a mídia, provocando a mídia até com relatórios diários. Ficou cômodo para a mídia receber essas informações. A meu ver, essas informações são fortemente carregadas do discurso financeiro. Dessa forma, a decisão econômica é totalmente distorcida, desproporcional. Então você abre os jornais, você vê televisão, ouve rádio, falou de economia, está associado a finanças. Naturalmente, na defesa de interesses muito próprios. Mas isso é óbvio, é uma tendência natural. Quem está no setor produtivo vai ter um viés para a produção, quem está no sindicato, vai ter um viés para o trabalhador. $\mathrm{O}$ problema que aponto é o predomínio fantástico. Esse poder para o mercado financeiro junto com a corrente mainstream da análise econômica, que é muito pró-mercado, criou o pensamento único.

\section{P: Mainstream?}

ACL: Academia. Os recursos para pesquisas, análises, publicação, consultoria etc. na área financeira é muito maior do que em outras áreas. Assim, muita gente que aparentemente é um acadêmico teoricamente isento, na verdade reflete muito dessa visão financeira. Porque geralmente, além de acadêmico, ele é um consultor que basicamente atende ao mercado

financeiro. É impossível ele não associar uma coisa a outra, e isso distorce a meu ver a análise econômica. 


\section{P: Como o senhor analisa o noticiário?}

ACL: O leitor está recebendo uma informação aparentemente isenta, mas que está carregada de informações. Eu vejo que os jornais, pelo menos, falam assim: “-Tal análise, do economista tal, economista do banco X”. Então pelo menos fica mais claro. Na televisão eu acho pior ainda, porque soltam uma medida do governo, e o telejornal vai e ouve um economista. Para o cara que está ouvindo é um economista isento, e o cara trabalha num banco. Só que não sei por que eles não colocam o nome do banco. Só que é claro que a análise daquele cara é a visão do banco sobre aquela medida.

\section{P: Aponte alguma distorção...}

ACL: O noticiário diz: "-A bolsa caiu 5\%", como se fosse algo relevante, o fim do mundo, mas não é tão relevante, é um movimento diário de compra e venda. Tem coisa muito mais importante acontecendo no ambiente econômico, mas se dá as costas para outras coisas. A bolsa cai hoje, sobe amanhã. A distorção é que a imprensa brasileira repete o padrão da imprensa norte-americana. É claro que a bolsa está crescendo no Brasil. Mas, evidentemente, mesmo descontado a proporção do tamanho da economia norte-americana para a brasileira, o papel da bolsa nos Estados Unidos é muito diferente do papel da bolsa no Brasil. É desproporcional relativamente ao tamanho da economia. Então, o que acontece, a bolsa nos Estados Unidos realmente tende a refletir o estado de ânimo da economia um pouco mais facilmente. No Brasil, como a mídia repete, vai tentar explicar. “A bolsa hoje caiu 2\%". Isso muitas vezes não tem nada a ver com o movimento econômico. E aí a mídia vai ouvir os analistas. E os analistas, é óbvio, vão vender o peixe deles: “-A bolsa caiu porque o Hezbollah atacou não sei o quê". "-Porque o presidente do Fed falou 
que...”, “-Porque a Heloísa Helena subiu na pesquisa”. Na verdade muitas vezes não tem nada a ver.

\section{P: Então para que essas explicações? Para justificar o movimento especulativo?}

ACL: Não para justificar, mas para dar uma ideia de que o processo tem uma lógica. E não tem tanta lógica, porque eu seu pegar os movimentos de longo prazo tem uma lógica, claro, mas os movimentos de curto prazo, diários ou semanais, não seguem lógica. Essas são algumas das críticas que eu faço à abordagem da mídia em relação à economia. Você vê o debate de juros, por exemplo, todos os jornais repetem isso, parece que vocês combinam (risos). "-Vamos ouvir os economistas", mas é tão engraçado, que eles fazem aquela tabelinha e colocam "economista tal", aí você olha, "Banco Bradesco, economista tal", aí a conclusão da matéria: “-O consenso é que realmente (a taxa de juros referencial da economia brasileira, a Selic) vai cair 0,5 ponto percentual". E isso é uma relação incestuosa porque é o seguinte: $\mathrm{O}$ BC faz o boletim Focus (já descrito), ele vai e ouve o mercado. Aquilo lá é banco, mas o BC diz que ouve todo mundo, na verdade ele ouve os bancos. Aí, os bancos falam assim: “-Olha, os juros vão cair 0,5”, aí aquilo vira consenso, e depois quando o Copom segue o consenso, a mídia vai dizer: “-Copom ouve as expectativas”.

$\mathrm{Na}$ verdade, isso acontece porque o governo é refém do mercado. Primeiro, porque ele tem uma dívida de um trilhão, financiada via mercado, e segundo porque o mercado é o formador de opinião, então ele quer estar bem com o formador de opinião. Então o mercado tem uma grande influência sobre o governo e sobre a mídia.

\section{P: Mas quando toda essa financeirização começou por aqui?}


ACL: O Plano Real responde ao movimento financeiro mundial na medida em que atrela sua moeda ao dólar num primeiro momento e perpetua a questão do juro alto. Porque o juro alto no Brasil, no passado, sempre foi associado à expectativa de inflação. Então, você dominou a inflação, mas o juro continuou alto...

Até os anos 1970 e todo o período de industrialização, o Brasil seguiu um caminho próprio, com os seus erros e acertos. Ele ousou desenvolver o seu próprio modelo. Tem um livro curto do Celso Furtado que ele trata disso, chama "Construção interrompida". Ele diz que existia um modelo com todos os seus acertos e erros e esse modelo foi perdido e substituído pelo pensamento único.

\section{P: Mas a manutenção do juro alto não é por causa da memória inflacionária...}

ACL: Você pode encontrar uma série de justificativas, tem a tese da incerteza jurisdicional, que a meu ver é algo que reflete muito dessa distorção de análise, mas o fato é que você prevalece com o juro elevado. Veja que a nossa mídia ela é muito voltada para o aspecto financeiro, e isso é sintomático, porque a Folha de S. Paulo, o caderno dela era chamado Economia, e hoje ele chama Dinheiro. Então ela assume que aquilo é realmente um caderno de finanças.

\section{P: O senhor percebe um jornal mais financeirizado que outro?}

ACL: Eu acho que em geral todos eles são financeirizados. Talvez alguns se preocupem mais em ter status divididos, mas eu diria que a tendência é prevalecer finanças mesmo. $\mathrm{O}$ relevante é que ao assumir uma única visão, a mídia ajuda a limitar as alternativas de desenvolvimento, de crescimento do País. É claro que não existe política econômica neutra. Ao adotar um pensamento único, uma política econômica única, você cria transferências de 
renda. Atualmente, quem é que se beneficia dessa transferência no Brasil nos últimos 20, 30 anos? São os rentistas. Eu poderia dizer "o mercado financeiro", mas em alguns casos o mercado financeiro é apenas agente. Todos nós que aplicamos no mercado financeiro recebemos parte dessa renda. Então, a nossa política econômica financeirizada é perversa porque ela premia quem tem capital. O capitalismo, por natureza, é assim. No caso brasileiro, você vai ver muitos empresários que venderam as suas operações para viver dessa renda obtida com operações do mercado financeiro...

\section{P: Como o senhor avalia os departamentos econômicos dos bancos?}

ACL: Essa ideia vem da economia norte-americana e da própria necessidade do mercado. $\mathrm{Na}$ verdade, os bancos precisam desses profissionais, porque o mercado se sofisticou demais, e a demanda dos clientes para essas análises também cresceu. Aí, eles transformaram as análises em um produto, ou é vendido ou oferecido gratuitamente aos cientes. Pelo status que têm, no mundo inteiro desfrutam de bom espaço na imprensa. No caso brasileiro, o espaço é maior, porque pelas especificidades da nossa economia, com inflação, indexação, todos aqueles processos, surgiu um profissional bom de análise, bom de comunicação, e os bancos disputam, você já percebeu isso, quem sai na frente.

\section{P: O que o senhor acha da predominância dos métodos econométricos nas análises dos bancos, na projeção que eles fazem do futuro econômico do País?}

ACL: Na verdade, a economia é um produto que tem uma série de fatores que você precisa levar em conta e que não são neutros. Então para uma análise econômica completa, você teria que usar o apoio desses instrumentos econométricos, mas também a experiência, o feeling, olhares de experiências internacionais e aprender com elas, porque isso diminuiria 
seu risco. Mas isso tem a ver muito com objetivo. Objetivo da política econômica. E tem um fator político por trás, por exemplo, se você imaginar “-Por que o FHC1 (refere-se ao primeiro mandato de Fernando Henrique Cardoso na presidência) errou no câmbio, corrigiu e vem o (presidente Luiz Inácio Lula da Silva, sucessor de FHC) Lula e repete o erro do FHC1?" Se você for ver, os motivadores provavelmente são os mesmos. O FHC1 errou no câmbio porque aquilo lhe favorecia eleitoralmente, o FHC2 (segundo mandato) não pôde fazer a mágica porque ele já tinha gastado todo o seu capital no FHC1. No FHC2, ele teve que cair na realidade. O Lula pegou o câmbio ajustado e percebeu que tinha chance de provocar uma deflação no País, uma desinflação valorizando o câmbio, com todos os efeitos perversos que pode ter sobre a produção nacional. Toda a equipe sabe disso. Mas, predomina o interesse político, que também favorece determinados grupos rentistas, porque essa política é uma maravilha para quem arbitra. Mas traz efeitos perversos para a economia, investimento cai, exportação, produção, mas provavelmente para quem especulou foi um muito bom negócio. A econometria não leva nada disso em conta.

\section{P: O senhor acha que a mídia no geral sofre a influência do mercado financeiro em parte porque está endividada?}

ACL: Pode ou não, essa é uma hipótese, teria que ser investigado. Já ouvi falar, mas não saberia te dar elementos que confirmam ou não essa hipótese. Além disso, o mercado financeiro também é um forte anunciante, o governo também é forte anunciante. Então eu acho que existe uma influência nisso, pelo menos sobre esse aspecto.

\subsubsection{COMENTÁRIOS}


As pesquisas de conteúdo editorial e as entrevistas dirigidas forneceram uma dimensão quantitativa da financeirização. Os depoimentos a seguir foram além do discurso manifesto no noticiário para mostrar o processo social da financeirização editorial. Foram essas entrevistas que revelaram as estratégias comunicacionais que o sistema financeiro utilizou para se tornar o porta-voz do saber econômico na mídia. Mostraram o papel das assessorias de imprensa, dos departamentos econômicos e da disponibilidade dos economistas do mercado na construção do noticiário, e sobretudo a questão ideológica por trás da aproximação entre financistas e jornalistas. As entrevistas permitiram inclusive que se delineasse o processo histórico da financeirização do noticiário, destacando que no regime militar a equipe de Delfim Netto, na Fazenda (fim dos anos 1960) já começava a bombardear os jornalistas com informações econômicas, até para tirar o foco da política.

Naquela época, os bancos ainda não entravam no noticiário. Mas logo que começou a abertura política foram conseguindo espaço. Primeiro, contou Pedro Cafardo, porque seus economistas eram menos teóricos e menos engajados politicamente do que os acadêmicos. Depois, e principalmente, eles quiseram estar no noticiário para vender seus produtos financeiros dentro de um ambiente de corrosão da renda pela inflação. No início dos anos 1980, os economistas de bancos viviam nos bares de jornalistas, fazendo amizade, disse Marco Antonio Rocha. Era o período em que o mundo das finanças tornava-se mais dinâmico. Começaram a surgir as assessorias de imprensa voltadas para o segmento de bancos, corretoras e consultorias, ao mesmo tempo em que os departamentos econômicos passaram a ser utilizados dentro das estratégias de comunicação do sistema financeiro. Com o Plano Real, lançado em 1994, os economistas de bancos passaram também a falar de 
macroeconomia, já que o Brasil adotara o modelo econômico neoliberal. O mercado de capitais impulsionou o jornalismo de negócios, antes visto como propaganda pura das empresas.

As entrevistas mostraram que o sistema financeiro é provavelmente o grupo mais bem organizado da sociedade na defesa de seus interesses. Além de dispor de enormes recursos, os bancos têm representantes altamente profissionais. Quem defende as teses do sistema financeiro são economistas do mais alto nível, com inserção social e intelectual forte, inclusive na academia, e que dispõem obviamente de prestígio na mídia. Nessa linha, Boris Tabacof citou os "pais do Plano Real", que ora estão no sistema financeiro, ora no governo, ora de volta aos bancos. Isso faz com que o próprio governo, representado por esses profissionais, defenda perante à sociedade ideias de um determinado grupo como sendo de interesse nacional. Além de cada banco isoladamente, o setor é representado também pela Febraban (Federação Brasileira de Bancos), a Anbid (associação dos bancos de investimento) e Apimec (associação dos analistas do mercado de capitais).

O economista Alexandre Schwartsman afirmou que dar entrevistas faz parte de seu trabalho, uma atividade estimulada pelo próprio banco em que trabalha. Ao mesmo tempo em que o banco passa uma imagem de qualidade técnica para os leitores, participa do debate econômico público. Diretor de um grande banco, $\mathrm{Z}$ contou que é constantemente chamado a Brasília para reuniões com autoridades econômicas. Tais reuniões fazem parte de uma política de bastidor muito intensa que os bancos executam, conversando secretamente com o Banco Central e o Ministério da Fazenda.

Quando se fala em competência organizacional, deve-se destacar a relevância dos 268 
departamentos de economia. O avanço tecnológico sofisticou o mercado financeiro, e a sofisticação chegou à análise econômica. Bancos, corretoras e fundos de investimentos montaram ou consolidaram equipes para fornecer análises a clientes e a eles próprios. As instituições perceberam que o, ao mesmo tempo, o trabalho desses departamentos poderia também fazer parte de estratégias comunicacionais. As equipes ganharam economistas dispostos a atender à mídia, provocando- a com relatórios diários e informações obviamente carregadas do discurso financeiro. Para os jornalistas, ficou cômodo receber essas informações, ainda mais que sempre vinham acompanhadas dos contatos dos economistas. Era ler o relatório, ter ideia de matéria e ligar para o economista.

Assis contou que nos últimos anos a forma mais comum de contato entre o jornalista e a instituição financeira tem mesmo sido o departamento econômico. Mais até do que a assessoria de imprensa. Geralmente após os primeiros contatos, o jornalista já tem os telefones mais pessoais do economista, parte de uma disponibilidade de comunicação que não existe, por exemplo, no mundo empresarial. Schwartsman lembrou que alguns jornalistas têm até o telefone da casa dele, para o caso de precisarem telefonar em um horário mais apertado de fechamento. Outra forma também comum de abordagem é a que vem dos economistas. Muitos ligam para as redações perguntando qual o profissional que cuida de determinada área e se oferecem para comentar ou sugerir ideia de matéria. Isso acontece até mesmo em instituições que têm assessoria de imprensa. Nassif ressaltou que os economistas de mercado praticam um discurso altamente convincente e assertivo, sobre o qual qualquer pensamento discordante é desqualificado. Os repórteres, por sua vez, sentem-se inseguros em questionar qualquer afirmação que venha deles. O Banco Central e a Fazenda acompanham todo esse noticiário gerado pelo sistema financeiro. 


\section{CAPÍTULO 6}

\section{CONCLUSÕES}

O trabalho foi concebido para mostrar:

a) O provável início e a consolidação do processo de financeirização do noticiário econômico no período 1989-2002, que abarca o fim do primeiro governo pós-ditadura (José Sarney), passando por Fernando Collor de Mello e Itamar Franco, até o término do período FHC (Fernando Henrique Cardoso);

b) $\mathrm{O}$ uso de um arsenal de estratégias comunicacionais utilizado pelos agentes do neoliberalismo financeiro para construir seus espaços na imprensa.

O item a) foi desenvolvido a partir de dois levantamentos quantitativos, demonstrados nas pesquisas de conteúdo editorial dos jornais, no Capítulo 4.

A primeira das duas pesquisas compilou a prevalência de fontes entre todas as matérias da amostragem. Foi uma avaliação exclusivamente de fontes, categorizadas segundo suas procedências. O resultado mostrou que, exceto em 1989, fontes ligadas ao mercado financeiro foram mais ouvidas do que quaisquer outras na amostra de 14 anos. Em 1989, fontes do governo e empresários ainda prevaleceram sobre as outras. Mas a partir de 1990, quando os economistas do mercado financeiro ingressaram no noticiário para explicar os produtos que seus bancos ofereciam contra a corrosão do dinheiro pela inflação, a financeirização tornou-se mais explícita. Em 1992, os agentes do mercado financeiro deixaram de aparecer exclusivamente em matérias sobre aplicações e passaram a repercutir e opinar sobras ações do governo, sobretudo no que tange às reformas recomendadas pelo “Consenso de Washington". 
O segundo grupo de pesquisas de conteúdo editorial analisou apenas a principal matéria de cada página do noticiário econômico, que são as matérias-manchetes, conhecidas no jargão jornalístico como abres-de-página. São as que ficam no alto de cada página. Foram compilados primeiramente os cinco temas de maior predominância em cada ano. Depois, cada um desses temas foi subdivido em levantamento de a) número de fontes e b) categoria/procedência de fontes.

Verificou-se que em 13 dos 14 anos da amostra - a exceção foi 1989 -, assuntos ligados aos interesses do mercado financeiro estiveram sempre presentes entre os cinco de maior prevalência. Nos primeiros anos, eram matérias sobre fundos de investimentos e mercados de ações, câmbio e juros, além de medidas do Banco Central que afetavam o funcionamento do mercado de capitais. A partir de 1992, a financeirização ganhou contornos ideológicos, traduzidos no noticiário pela presença preponderante de temas ligados ao modelo econômico neoliberal do "Consenso de Washington", como reformas, privatizações, corte das contas públicas e abertura à entrada de bens, serviços e capitais estrangeiros no País.

O que chamou particular atenção foi que a vertente ideológica da financeirização não foi introduzida no noticiário pelos economistas do mercado financeiro ou por banqueiros, mas pelo discurso do próprio governo - a categoria de fontes que mais apareceu nos abres-depáginas. Significa dizer que o governo deu o tom ideológico à financeirização, colocando os interesses do capital financeiro no noticiário como sendo de amplo interesse nacional. A título de ilustração, a primeira vez em que a amostra trouxe uma autoridade defendendo pressupostos neoliberais foi em 1990, na Folha, em matéria baseada em discurso do então ministro da Fazenda Mailson da Nóbrega.

É claro que o Fundo Monetário Internacional (FMI), o Banco Mundial (BIRD), o Banco de Compensações Internacionais (BIS) e o Instituto de Finanças Internacionais (IIF), que representa os grandes bancos mundiais, também estiveram presentes nas manchetes de páginas para defender os interesses do neoliberalismo financeiro, mas em escala muito menor do que as autoridades brasileiras. 


\section{Brasil deve gastar menos e exportar, diz FMI}
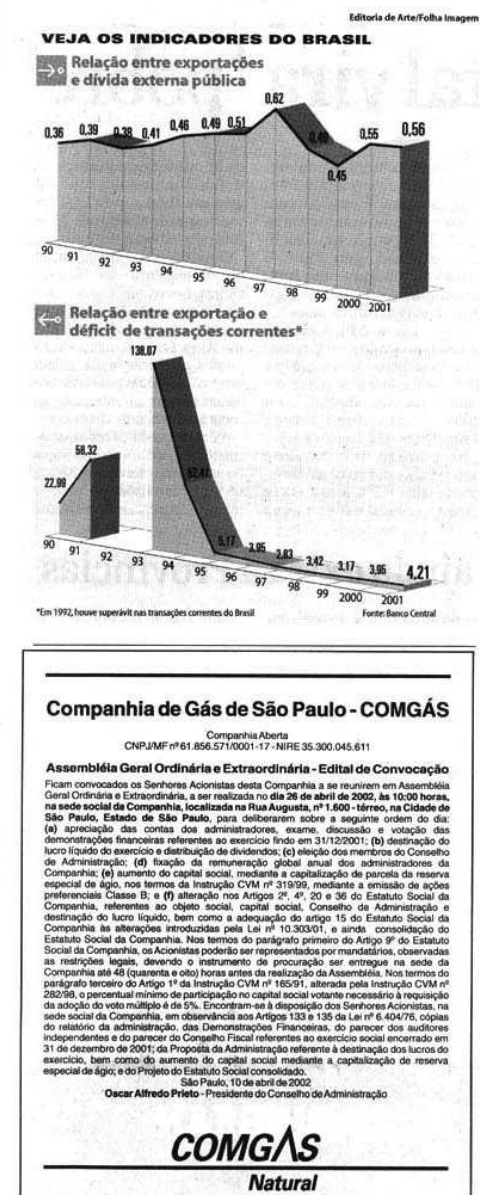

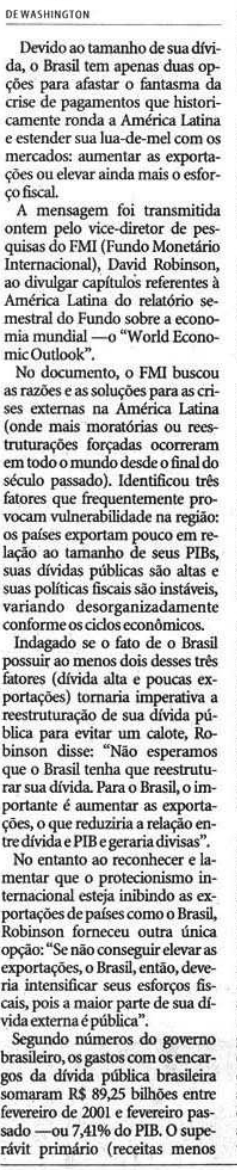

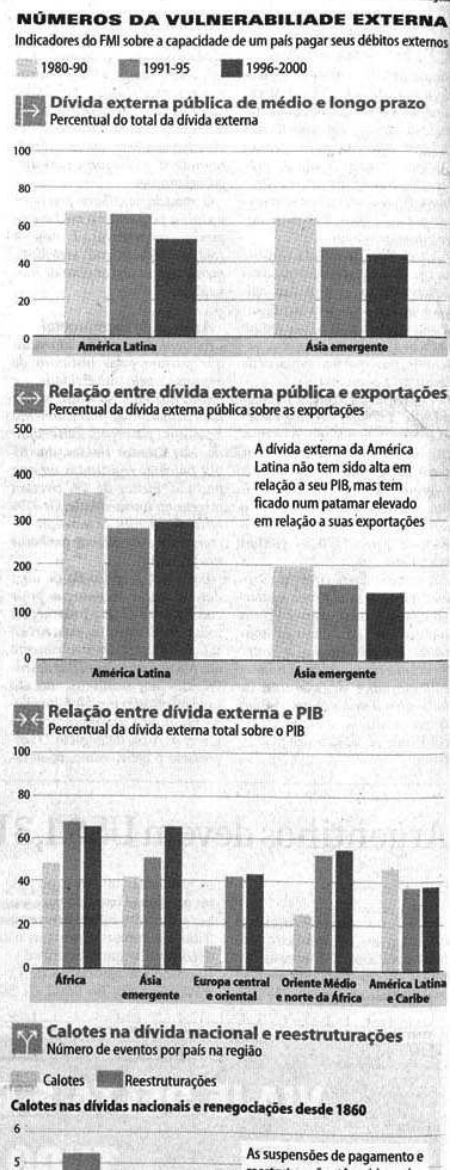

Figura 119. Fundo Monetário Internacional (FMI) dá a receita para o Brasil se desenvolver (FSP, 10/4/2002). Reprodução fotográfica pelo Acervo do Estado de São Paulo.

Já os bancos propriamente ditos apareceram poucas vezes nos abres-de-página "cobrando" reformas do governo brasileiro. Não deixaram de desempenhar a cobrança, mas o fizeram em matérias secundárias. Também a título de ilustração, a amostra trouxe em 1996 pela primeira vez uma matéria-manchete com a crítica dos grandes bancos estrangeiros à suposta lentidão das reformas no Brasil, por conta da resistência do Congresso em votá-las. A matéria se referiu aos economistas como "a nata de brasilianistas da City e de Wall 
Street" (bairros onde se situam os centros financeiros de Londres e de Nova York) - figura 110 página 170.

Outro resultado que chamou atenção e era tampouco esperado foi o contraste entre a presença diária nas matérias-manchetes de notícias sobre reformas, privatizações, impostos, gastos públicos, arrecadação, câmbio, taxas de juros, superávits, déficits, impostos e crescimento, e a ausência de assuntos igualmente da área econômica, mas de cunho social, como investimentos em saneamento básico, transportes públicos e habitação, por exemplo. Esses assuntos não aparecerem em nenhum dos 14 anos da amostra de abres-de-páginas.

O governo predominou como fonte dos abres-de-páginas em todo o período analisado, seguido por profissionais do mercado financeiro e empresários. Junto com a redução da escalada inflacionária obtida com o Plano Real, a participação do setor empresarial no noticiário ganhou contornos de negócios, e não mais como de principal motor da economia brasileira. Com o avanço do mercado acionário, as empresas foram se capitalizar na Bolsa de Valores, levando o enfoque do noticiário empresarial ao encontro dos interesses dos investidores que compraram suas ações.

Os sindicalistas apareceram algumas vezes nos altos de páginas, em matérias sobre greves e negociação salarial. Já os institutos de pesquisas apareceram quando da divulgação de índices inflacionários ou algum levantamento mais específico de preços setoriais.

No que se refere à transparência do noticiário, o governo foi a categoria menos transparente da amostra de matérias-manchetes. Veio do governo o maior número de matérias com fontes não-identificadas ou sem fonte, confirmando a prática bastante comum de vazamento de informações para a imprensa, via segundo escalão do governo, para testar reações. Entre as matérias sem fontes da amostragem, prevaleceram aquelas referentes à preparação e ao andamento pós-anúncio do Plano Real, de 1994. Nenhuma matéria sobre o tema identificou fonte, nem mesmo "fontes próximas ao tema" ou "assessores" não-identificados. Nada. A 
prática do governo foi fornecer aos jornalistas, na condição de anonimato, pedaços do que seria a nova política econômica. Com isso, era fácil testar a reação dos diferentes níveis da opinião pública sobre determinada proposta. O jornalista, em troca, tinha uma notícia exclusiva, um furo.

As matérias com temas e/ou fontes do mercado financeiro ficaram em segundo entre as menos transparentes. Na prática, os economistas preferem não se identificar para evitar conflitos com governo e para não aparecer publicamente influindo na agenda nacional. Foi mais comum aparecerem "economistas disseram", "o mercado disse", "segundo economista de um grande banco". Já as matérias mais transparentes pelo critério de identificação foram as que tiveram os sindicalistas como fontes.

No que se refere ao b) arsenal de estratégias comunicacionais com que o sistema financeiro construiu seu espaço no noticiário, uma das principais constatações - e que só foi possível identificar por conta das entrevistas - foi o relevante papel dos departamentos de economia na relação economistas/jornalistas. A função dessas divisões é elaborar análises para clientes pagantes e ao próprio banco, mas $82 \%$ delas enviam esse mesmo material gratuitamente para os jornalistas. Isso denota uma função comunicacional, pois o relatório chega aos jornalistas mesmo sem ter sido solicitado. Os jornalistas se acomodaram com essa oferta e ouvem sempre as mesmas fontes.

Outro dado que revelou intencionalidade comunicacional foi a ampla contratação de assessorias de imprensa pelas instituições financeiras. Além do contato mais facilitado com as redações, os assessores também introduziram os treinamentos (media training) para ensinar os economistas a dar entrevistas. Quem não tinha assessoria, usava os próprios economistas para fazer as vezes do assessor de imprensa, enviando aos jornalistas os relatórios com análises, opiniões, emails e telefones ou telefonando diretamente para as redações. 
As entrevistas abertas transcritas no Capítulo 5 verbalizaram estratégias e intenções do sistema financeiro por trás da construção do noticiário econômico, bem como a problemática da financeirização. Essas entrevistas talvez tenham sido o grande diferencial do trabalho, porque revelaram o que os números não foram capazes de demonstrar sozinhos. Foram também os depoimentos que conseguiram dar o grau da ideologização e dos interesses do neoliberalismo financeiro. Os depoimentos revelaram os papeis da racionalidade técnica, dos departamentos econômicos, das assessorias de imprensa e da disponibilidade dos financistas em ações operacionalizadas junto à imprensa, bem como o processo de ideologização do noticiário. Ficou bastante cômodo para os jornalistas receber material dos bancos e ter sempre à mão o telefone dos economistas. Falar com os jornalistas faz parte do trabalho dos analistas, e os próprios bancos estimulam esse contato. Ao mesmo tempo em que passa uma imagem de qualidade técnica aos leitores dos jornais, a instituição se posiciona no debate econômico público.

Em resumo, este trabalho mostrou:

1) O predomínio de fontes provenientes do sistema financeiro, quando considerada toda a amostragem do noticiário econômico, de 1989 a 2002 (pesquisa 1).

2) A predominância de temas de interesse do mercado financeiro nas matériasmanchetes do noticiário econômico - pesquisa 2. O levantamento mostrou ainda algo inesperado: como as fontes do governo predominaram entre as matérias escolhidas para abrir cada página do noticiário econômico e como nessas mesmas matérias o assunto predominante era de interesse do mercado financeiro, o cruzamento dos dois resultados revelou que o governo brasileiro assumiu de tal forma a agenda do neoliberalismo financeiro que acabou sendo seu principal portavoz no noticiário.

3) Que os financistas apareciam noticiário econômico do final do governo José Sarney (1985-1989) para falar sobretudo dos tipos de instrumentos que seus bancos 
ofereciam para proteger o dinheiro contra a inflação (novos tipos de fundos e aplicações no mercado acionário). Mas a financeirização mais ideológica começou em 1992, ainda no governo Fernando Collor (1990-1992), quando as próprias autoridades passaram a introduzir no noticiário temas ligados ao "Consenso de Washington", como reformas e privatizações. Nesse contexto, os profissionais do mercado financeiro deixaram de aparecer exclusivamente para falar de aplicações e passaram a repercutir e opinar sobre as ações do governo.

4) O sério contraste entre o predomínio de temas de interesse do neoliberalismo financeiro e a ausência de assuntos econômicos de cunho social, como investimentos em saneamento básico, habitação e obras de infraestrutura.

5) Que o governo foi a categoria menos transparente de fontes da amostra de matériasmanchetes.

6) O papel das assessorias de imprensa, dos media training, departamentos econômicos e da disponibilidade do sistema financeiro.

7) Ideias e opiniões que não condiziam com o pensamento neoliberal praticamente não apareceram entre as notícias econômicas. 


\section{REFERÊNCIAS BIBLIOGRÁFICAS*}

ALBRIGHT, M. A Dura Tarefa de Resgatar a Credibilidade do País. O Estado de S. Paulo. São Paulo, 5 de outubro de 2008. Caderno Nacional, página 10.

ALDÉ, A. A Construção da Política: democracia, cidadania e meios de comunicação de massa. Rio de Janeiro: Editora FGV, 2004. 216p.

et al. Critérios Jornalísticos de Noticiabilidade: discurso ético e rotina produtiva.

Revista Alceu, Rio de Janeiro, v. 5, n. 10, págs. 186-200, janeiro/junho de 2005.

ARAÚJO, A. A Escola do Rio: fundamentos políticos da nova economia brasileira. São Paulo: Editora Alfa Ômega, 1998. 144p.

BARBERO, J. M. Comunicacion Massivo: discurso e poder. Quito: Época/Ciespal, 1978. $252 p$.

BATISTA JUNIOR, P. N.; RANGEL, A. S. A Renegociação da Dívida Externa e o Plano Brady: avaliação de alguns dos principais resultados. São Paulo: Pedex, outubro de 1994. 40p. (Caderno Dívida Externa, 7).

BATISTA, P. N. O Consenso de Washington: a visão neoliberal dos problemas latinoamericanos. São Paulo: Pedex, setembro de 1995. 55p. (Caderno Dívida Externa, 6).

BAUMANN, R. Os Anos 90 e o Paradoxo do Desenvolvimento. In: LACERDA, A. C. (Org.). Crise e Oportunidade: o Brasil e o cenário internacional. São Paulo: Lazuli Editora, 2006. Págs. 235-252.

BELLUZZO, L.G. As Transformações da Economia Capitalista no Pós-guerra e a Origem dos Desequilíbrios Globais. Política Econômica em Foco, Campinas, n.7, págs. 24-41, novembro de 2005/abril de 2006.

BOND, F. F. Introdução ao Jornalismo: uma análise do 4o. poder em todas as suas formas. Rio de Janeiro: Agir, 1962. 373p.

BOURDIEU, P. O Campo Econômico. Política e Sociedade, Florianópolis, v. 1, n. 6, págs. 15-57, abril de 2005.

; WACQUANT, L. O Imperialismo da Razão Liberal. Revista Possibilidades, Goiânia, ano 1, n. 1, págs. 24-28, julho/setembro de 2004.

; CHAMBOREDON, J-C.; PASSERON, J-C. O Ofício do Sociólogo. Petrópolis:

Editora Vozes, 2004b. 302p. 
BRANDÃO, H. N. Introdução à Análise do Discurso. São Paulo: Ed. da Unicamp, 1994. 96p.

BRITTOS, V. (Org.). Comunicação, Informação e Espaço Público: exclusão no mundo globalizado. Rio de Janeiro: Papel \& Virtual, 2002. 203p.

CALLON, M. (Edit). Introduction: The Embeddedness of Economic Markets in Economics. In: CALLON, M. The Laws of the Market. Oxford: Blackwell Publishers, 1998. Págs. 1-55.

CARDEAL, M. R. Do Jornal ao Portal. 2003. 150 f. Tese de Doutorado - Escola de Comunicações e Artes da Universidade de São Paulo, São Paulo, 2003.

CARNEIRO, R. A Supremacia dos Mercados e a Política Econômica do Governo Lula.

Política Econômica em Foco, Campinas, n.7, págs. 1-23, novembro de 2005/abril de 2006.

CASTORIADIS, C. A Instituição Imaginária da Sociedade. Rio de Janeiro: Paz e Terra, 1995. 418p.

CHAPARRO, M. C. Pragmática do Jornalismo: buscas práticas para uma teoria da ação jornalística.São Paulo: Summus, 1994. 132p.

CHERNAVSKI, E. Taxa Natural e Convenções: uma discussão dos determinantes da taxa real de juros no Brasil. In: ENCONTRO NACIONAL DE ECONOMIA POLÍTICA, 16, 2008. Artigo. Publicado em http://www.sep.org.br/artigo/1245_75f26571d240ced249e102af3a81d5ff.pdf. 25p.

COSTA, S.M. (Coord.). Investimento Social na Idade Mídia: discurso e imagem da iniciativa privada na imprensa brasileira. São Paulo: Gife e Andi, 2000. 50p. (Edição especial).

COUTINHO, L. Qual o Desenvolvimento que Queremos? Valor Econômico, São Paulo, 28, 29 e 30 de julho de 2006. Caderno A, página 11.

DUPAS, G. Atores e Poderes na Nova Ordem Global: assimetrias, instabilidades e imperativos de legitimação. São Paulo: Editora Unesp, 2005. 319p.

Tecnologia Médica, Vida e Morte Dignas. O Estado de S.Paulo, São Paulo, 17 de junho de 2006. Caderno Nacional, página 2.

ECO, U. Apocalíticos e Integrados. São Paulo: Perspectiva, 1976. 386p.

FARIA, A. M. O Jornalismo Econômico e a Cobertura sobre Privatização (1990/1991). 1994. 85 f. Tese de Mestrado - Escola de Comunicações e Artes da Universidade de São Paulo, São Paulo, 1994. 
FERRO, M. O Ensino, a Mídia e o Conhecimento. O Estado de S. Paulo, São Paulo, 13 de setembro de 2004. Caderno 2, página 16.

Federação das Indústrias do Estado de São Paulo (Fiesp). Livre para Crescer - Proposta para um Brasil Moderno. São Paulo: Fiesp, 1990. 28p.

FLIGSTGEIN, N. Social Skill and the Theory of Fields. Sociological Theory, Vancouver, v. 19, n. 2, págs. 105-125, julho de 2001 (a).

The Architeture of Markets: an economic sociology of twenty-first-century capitalist markets. Princeton: Princeton University Press, 2001(b). 274p.

FOUlCAUlT, M. Microfísica do Poder. Rio de Janeiro: Graal, 1979. 262p.

FUNDAÇÃO GETÚLIO VARGAS. Centro de Pesquisa e Documentação de História Contemporânea. Dicionário Histórico-Biográfico Brasileiro.

http://www.cpdoc.fgv.br/comum/htm/.

FURTADO, J. F. Globalização das Empresas e Desnacionalização. In: LACERDA, A. C. (Org). Desnacionalização: mitos, riscos e desafios. São Paulo: Contexto, 2000. Págs. 1242.

GALBRAITH, J. K. The Great Clash 1929. New York, Avon Books, 1980. 184p. . A Economia das Fraudes Inocentes. São Paulo: Companhia das Letras, 2004.

$84 \mathrm{p}$.

GANS, H. Deciding What's News: a study of CBS evening news, NBC nightly news, newsweek and time. New York: Pantheon, 1979. 393p.

GIANNOTTI, J.A. Deficientes Devem Ter Vagas no Ensino?. O Estado de S. Paulo. São Paulo, 1 de maio de 2009. Caderno Nacional, página 8.

GODBOUT, J. L. Introdução à Dádiva. Revista Brasileira de Ciências Sociais, São Paulo, v. 13, n. 38, págs. 39-52, outubro de 1998.

GOMES, M. R. Ética e Jornalismo. São Paulo: Escrituras, 2002. 95p.

Poder e Jornalismo. São Paulo: Edusp, 2003. 107p.

GÓMEZ, G.O. Implicancias Políticas y Pedagógicas de La Investigación Cualitativa. In: GÓMEZ, G.O. La Investigacion em Comunicacion desde La Perspectiva Cualitativa. La Plata: Universidade de La Plata, 1996. Capítulo V (págs. 95-112).

GORZ, A. Metamorfoses do trabalho: crítica da razão econômica. São Paulo: Annablume, 2003. 234p. 
GRÜN, R. Convergência das Elites e Inovações Financeiras: a governança corporativa no Brasil. Revista Brasileira de Ciências Sociais, São Paulo, v. 20, n.58, págs. 139-161, junho de 2005.

HA-JOON, C. Brasil se Atrasa por Vontade Própria, avalia economista.

Folha de S. Paulo, São Paulo, 19 de janeiro de 2009. Caderno Brasil, página 16.

HALL, S. et al. The Social Production in News: mugging in the media. In: COHEN, S.; YOUNG, J. (Eds.). The Manufacture of News. London: Constable, 1973. 2005. 102p.

A Identidade Cultural na Pós- Modernidade. Rio de Janeiro: DP\&A Editora, HARVEY, D. A Condição Pós-Moderna: uma pesquisa sobre as origens da mudança cultural. São Paulo: Edições Loyola, 2003. 349p.

$247 \mathrm{p}$

A Brief History of Neoliberalism. New York: Oxford University Press, 2007.

IANNI, O. Globalização: novo paradigma das Ciências Sociais. Estudos Avançados, São Paulo, vol. 8, n. 21, págs. 147-163, 1994.

KOVACK, B.; ROSENSTIEL, T. Os Elementos do Jornalismo: o que os jornalistas devem saber e o público exigir. São Paulo: Geração Editorial, 2004. 302p.

KUCINSKI, B. Jornalismo Econômico. São Paulo: Edusp, 1996. 240p.

Jornalismo na Era Virtual: ensaios sobre o colapso da razão ética. São Paulo: Editora Fundação Perseu Abramo/Editora Unesp, 2004. 141p.

KUHN, T. A Estrutura das Revoluções Científicas. São Paulo: Perspectiva, 1976. 257p.

LACERDA, A. C. (Org.). Desnacionalização: mitos, riscos e desafios. São Paulo:

Contexto, 2000. 141p.

. (Org.). Crise e Oportunidade: o Brasil e o cenário internacional. São Paulo:

Lazuli Editora, 2006. 328p.

LACHINI, C. Anábase: história da Gazeta Mercantil. São Paulo: Lazuli Editora, 2000. $332 \mathrm{p}$.

LEBARON, F. La Croyance Économique: les économists entre science et politique. Paris: Editions Du Seuil, 2000. 150p.

LOPES, M. I. V. Pesquisa em Comunicação: formulação de um modelo metodológico. São Paulo: Edições Loyola, 1994. 148p. 
LOPES, O. B. Fatos e Números: valores-notícias, quantidades e poder das fontes no jornalismo econômico. 2002. 105 f. Tese de Mestrado - Escola de Comunicações e Artes da Universidade de São Paulo, São Paulo, 2002.

LOUREIRO, M. R. Os Economistas no Governo: gestão econômica e democracia. Rio de Janeiro: Editora da Fundação Getúlio Vargas, 1997. 200p.

MAGALHÃES, J. P. A. Economia Brasileira: do pensamento único a vinte e cinco anos de semi-estagnação. Causas e soluções. Rio de Janeiro: Corecon-RJ, 2007. 85p.

MARX, K., ENGELS, F. A Ideologia Alemã. São Paulo: Martins Fontes, 2002. 117p.

MATELlaRT, A. A Globalização da Comunicação. São Paulo: Edusc, 2000. 191p. ; MATTELART, M. História das Teorias da Comunicação. São Paulo: Edições Loyola, 2004. 220p.

MORETZSOHN, S. Jornalismo em "Tempo Real": o fetiche da velocidade. Rio de Janeiro: Revan, 2002. 192p.

MORIN, E. Ciência com Consciência. Lisboa: Europa-América, 1982. 255p.

NASSIF, L. Os Financistas e os Cruzados. Folha de S. Paulo, São Paulo, 20 de novembro de 2003. Caderno Dinheiro, página 3.

NETTO, A. D. O progresso da Teoria. Revista Carta Capital. São Paulo, 21 de novembro de 2008, página 39.

NOBRE, M. Juros, Teoria e Prática. Folha de S.Paulo. São Paulo, 15 de abril de 2008, Caderno Brasil, página 2.

ORTIZ, R. Mundialização: saberes e crenças. São Paulo: Brasiliense, 2006. 210p.

PAULANI, L.; PATO, C. G. Investimentos e Servidão Financeira: O Brasil do último quarto de século. (Artigo a ser publicado), 2005. 30p.

Modernidade e Discurso Econômico. São Paulo: Boitempo, 2005. 214p.

. Neoliberalismo e Retórica: o capítulo brasileiro. Revista de Economia Política, v. 26, n. 1, págs. 3-22, janeiro/março de 2006.

. Brasil Delivery: servidão financeira e estado de emergência econômico. São Paulo; Boitempo, 2008. 150p.

POLANYI, K. A Grande Transformação: as origens da nossa época. Rio de Janeiro: Editora Campus, 1980. 217p. 
PORTER, T. M. Trust in Numbers: the pursuit of objectivity in science and publlic life. Princeton: Princeton University Press, 1995. 310p.

PRADO, M.C.R.M. A Real História do Real. Rio de Janeiro: Record. 2005. 573p.

QUEIROZ, C; RIBEIRO, E; LIMA, P. V. Guia Brasileiro de Comunicação Empresarial e Assessoria de Imprensa - Produtos \& Serviços. São Paulo: Sindicato dos Jornalistas Profissionais do Estado de São Paulo/Editora Puente, 2001. 233p.

QUADROS, W. Brasil: estagnação e crise. São Paulo: Gelre, 2004. 36p. (Série Estudos do Trabalho, 1).

QUINTÃO, A-S. F. O Jornalismo Econômico no Brasil depois de 1964. Rio de Janeiro: Agir, 1987. 214p.

RAMONET, I. O Pensamento Único e os Novos Senhores do Mundo. Cultura Brasileira, disponível em http://www.culturabrasil.org/pensamentounico_ramonet.htm/. 1995. 28p.

RESENDE, J. V. Construtores do Jornalismo Econômico: da cotação do boi ao congelamento de preços. São Paulo: Secretaria de Abastecimento e Agricultura, Série Discussão Apta 3, 2003. 355p.

ROCHA, J. C. Um Debate Necessário: o poder da comunicação. [Entrevista]. Jornal da USP, São Paulo, 11 de maio de 1992, página 13.

ROUBINI, N.; RICHARDSON, M. Nem os Pessimistas Acertaram. O Estado de S. Paulo, São Paulo, 15 de fevereiro de 2009. Caderno Nacional, página 2.

SANDRONI, P. Dicionário de Economia. São Paulo: Abril Cultural, 1985. 459p.

SEN, A. Sobre Ética e Economia. São Paulo: Companhia das Letras, 1999. 144p.

SILVA, J. P. A Broadcast, o Mercado Financeiro e a Cobertura de Economia da Grande Imprensa. 2002. 122 f. Tese de Mestrado - Faculdade de Comunicação da Universidade Federal de Brasília, Brasília, 2002.

SODRÉ, N. W. História da Imprensa no Brasil. Rio de Janeiro: Mauad, 1999. 501p.

SOLOMON, R. O Sistema Monetário Internacional 1945-1976. Rio de Janeiro, Zahar Editores, 1979. 410p.

SOUSA, J. P. Por que as notícias são como são: construindo uma teoria da notícia. Biblioteca on-line das Ciências da Comunicação (http://www.bocc.ubi.pt./_esp/autor.php?codautor=13), 2002.17p.

SOUZA, J. Em Crise, Jornalismo Vira Profeta do Acontecido. Folha de S. Paulo, São Paulo, 2 de maio de 2004. Caderno Brasil, página 13. 
SOUZA, N. A. Economia Brasileira Contemporânea: de Getúlio a Lula. São Paulo: Editora Atlas, 2007. 342p.

STEINER, P. A Sociologia Econômica. São Paulo: Editora Atlas, 2006. 134p.

THIOLLENT, M. Sobre a Enquete Operária. In: THIOLLENT, M. Crítica Metodológica, Investigação Social e Enquete Operária. São Paulo: Polis, 1980. Capítulo IV (págs. 101133).

TRAQUINA, N. Teorias do Jornalismo: por que as notícias são como são (Volume I). Florianópolis: Editora Insular, 2004. 224p.

UNIVERSIDADE DE SÃO PAULO. Sistema Integrado de Bibliotecas-SIBi. Grupo DiTeses. Diretrizes para apresentação de dissertações e teses da USP: documento eletrônico e impresso. São Paulo: SIBi-USP, 2004. 110p. (Cadernos de Estudos, 9).

WEBER, M. A “Objetividade” do Conhecimento nas Ciências Sociais. São Paulo: Editora Ática, 2006. 106p.

WILliAMSON, J. Consenso Atenuou Crise no Brasil. [Depoimento a Patrícia Campos Mello]. O Estado de S.Paulo. São Paulo, 12 de abril de 2009. Caderno de Economia, página 7.

WOLF, M. Teorias da Comunicação. Lisboa: Presença, 2001. 271p.

*Segundo normas da Associação Brasileira de Normas Técnicas (ABNT) - NBR 6023

\section{ENTREVISTAS}

ASSIS, F. C. Depoimento em abril de 2008 (gravado e transcrito).

ASSESSOR DE IMPRENSA NÃO-ID. Depoimento em agosto de 2008 (gravado e transcrito).

CAFARDO, P. Depoimento em junho de 2008 (gravado e transcrito).

DIRETOR DE BANCO NÃO-ID. Depoimento em março de 2007 (parcialmente anotado e transcrito). 
KUCINSKI, B. Depoimento em janeiro de 2008 (anotado e não-transcrito).

LACERDA, A. C. Depoimento em agosto de 2006 (gravado e transcrito).

NASSIF, L. Depoimento em maio de 2009 (gravado e transcrito).

RAMOS, N. P. Depoimento em fevereiro de 2008 (gravado e transcrito).

ROCHA, M. A. Depoimento em abril de 2007 (gravado e transcrito).

SCHWARTSMAN, A. Depoimento em março de 2007 (gravado e transcrito).

TABACOF, B. Depoimento em novembro de 2006 (gravado e transcrito). 
ANEXOS 


\section{ANEXO A}

Amostra de imagens de matérias do período analisado, tiradas durante a pesquisa de conteúdo editorial e ajudam a ilustrar na prática a financeirização do jornalismo econômico. A reprodução das imagens foi feita pelo Arquivo Público do Estado, do Governo do Estado de São Paulo.

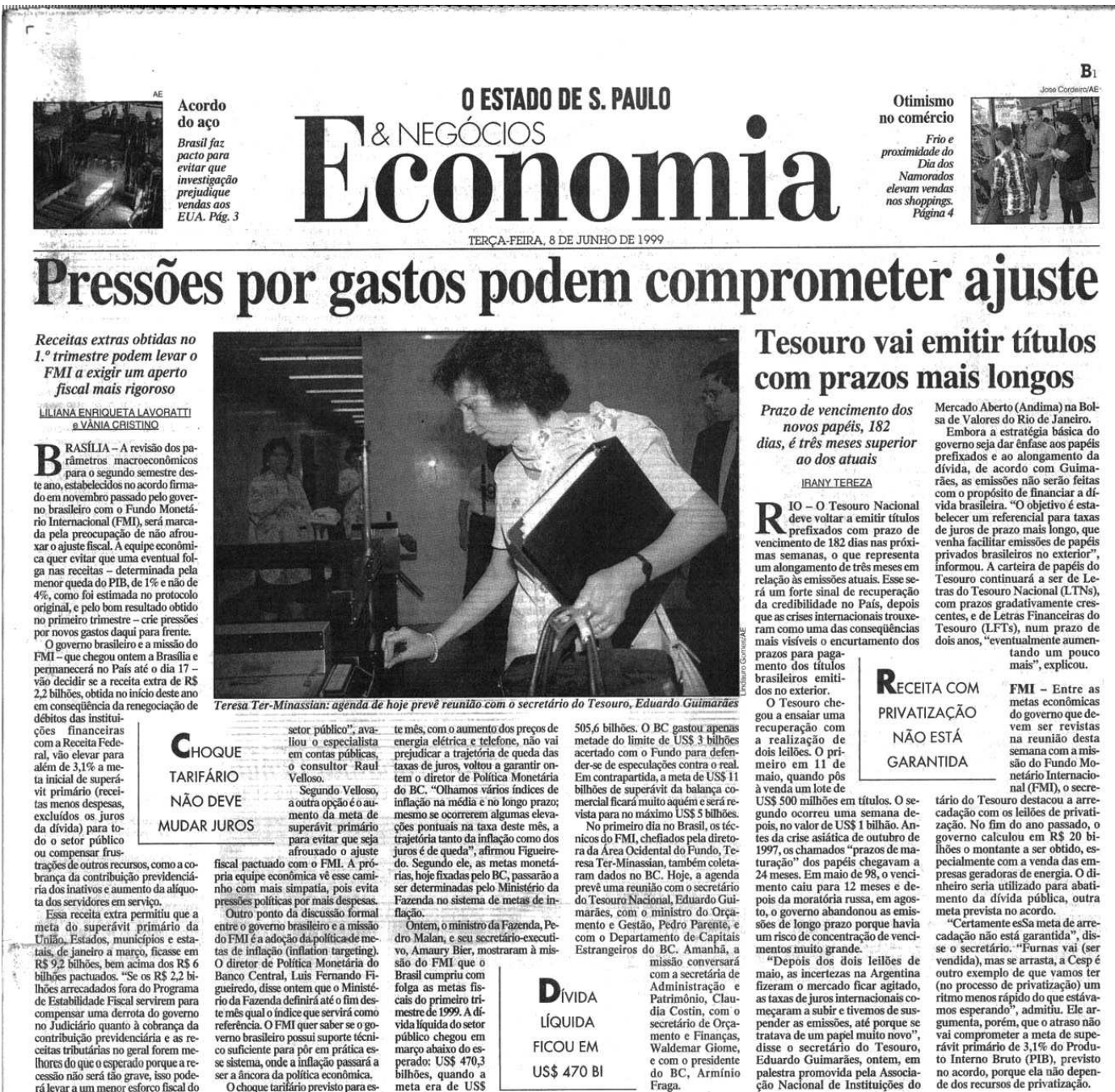

Figura 120. Matéria mostra pressão externa para contenção de gastos públicos (OESP, 8/6/1999). Reprodução fotográfica pelo Acervo do Estado de São Paulo. 


\section{B12-OESTADODES.PAULO \\ ECONOMIA \\ TERCA-FEIRA, 8 DE JUNHO DE 1999 Fi. MERCADO FINANCEIRO \\ Bolsas, juros e câmbio fecharam em baixa}

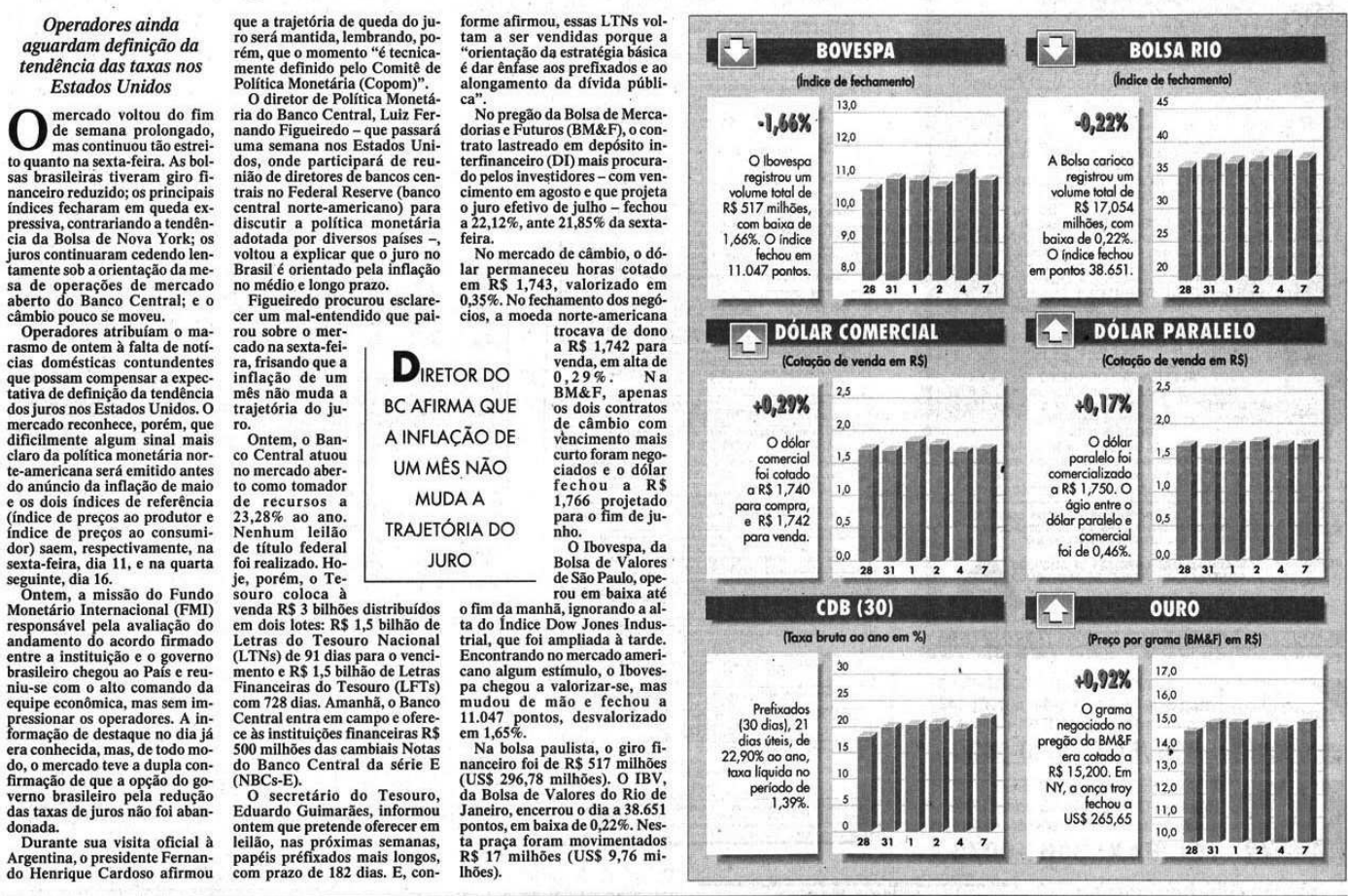

Figura 121. Coluna diária sobre o comportamento do mercado financeiro (OESP, 8/6/1999). Reprodução fotográfica pelo Acervo do Estado de São Paulo. 

BIS alerta para a sobrevalorização do dólar

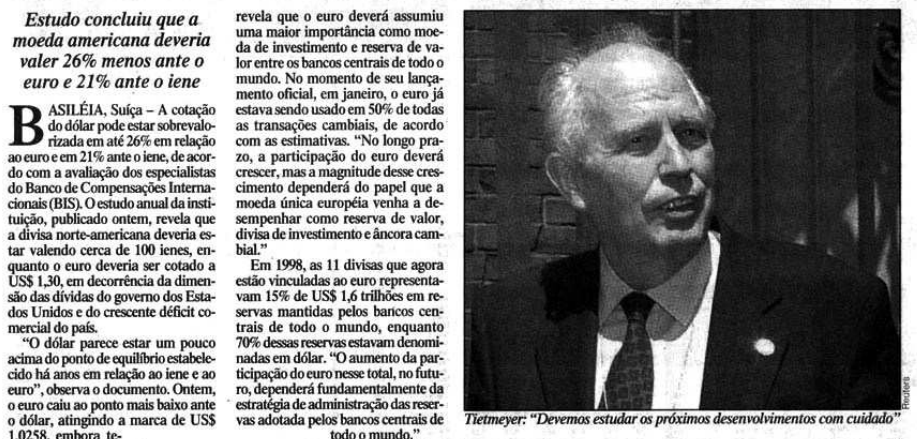
o dólar, atingindo a m
1,0258 , embora te-

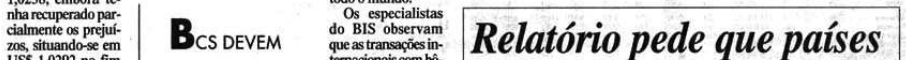

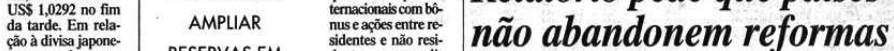

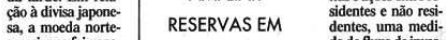

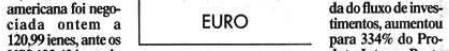

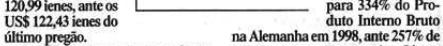

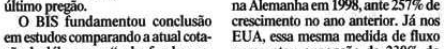

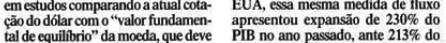

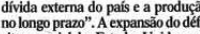
trangeires, que ficam lives para
car esses dolars por sua moeda agoraesse movimento tem sido con
pensado pelo fluxo positivo de inve

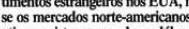
tamente recuará.
Orelaturio da instituição também

BASILÉLA - O presidente do queda do nivel de poupanga interma

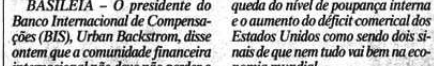

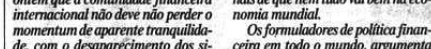
de, com o despararecimento dos 5 -
nais de crise, para realizar as refor.

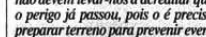
PIB em 1997. "Isso mostia que diantio graçăo dos merceados europeus de nuse titulos públicose en prvados.
Emboram as autoridades do Banco Central Europeut tenham dadodod
claraçóes recentes de despreocup çăac com a queda do ouro, Hans Tiettruais emergências mais adiante.
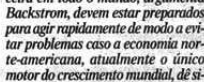
ignorar aloumas evidentes amea ca mundial, mas seria mais grave ter-se estabilizado depois da attimo
ainda näo corrigir os pontos de crise, mas recomenda cautela ae

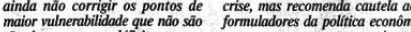

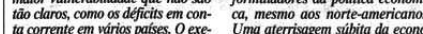

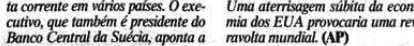
ser consistente com a "razão entre

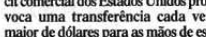
nais de crise, para realizar as refo
mas.

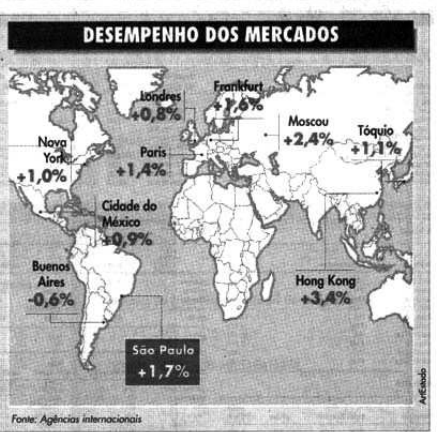

Fusões levam Bolsa de Nova York a fechar em alta de $1 \%$ Desempenho puxou pelo Comitê de Politica Monetária para cima os mercados do Banco da Inglaterra, que se reúda Europa e da

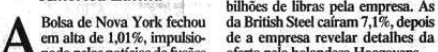

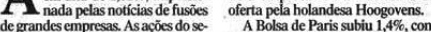
tor de tecnologia fecharam em alta, noticias locais e abertura positiva

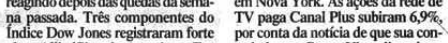

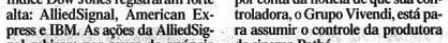
nal subiram por causa do anúncio de cinema Pathé. dos planos para compra da Ho- A Bolsa de
neywell, por USS 13,8 bilhóes A fu-
$1,611 \%$, liderada ponentes eletrônicos e equipamen- panhias exportadoras e do setor fi-

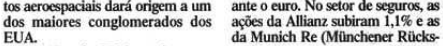
As açōes da IBM reagiram ao $\begin{aligned} & \text { da Munich Re (Mînchener Rücts } \\ & \text { versicherungs) avançaram } 1 \% \text {. }\end{aligned}$

Figura 122. Matéria na caixa traz instituição internacional e a pressão por reformas (OESP, 8/6/1999). Reprodução fotográfica pelo Acervo do Estado de São Paulo. 


\section{TERÇA-FEIRA, 9 DE MARÇO DE 1999 ECONOMIA \\ OESTADO DES.PAULO-B3 \\ Camdessus insta bancos privados a ajudar o País}

Diretor-gerente do Fundo $e$ mental para o sucesso do prograo secretario do 1 EUA respaldam esforço

$\frac{\text { PAULO SOTERO }}{\text { Correspondente }}$

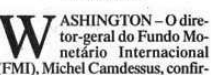
(FMI), Michel Camdessussconfir-
mou ontem sua intençáo de reco-

mendar a nova versấo do progra-
ma econômico brasileiro para os próximos três anos à diretoria exe-
cutiva da organizacáo.
0 anúncio pós novamente en O anúncio pốs novamente em
marcha a operą̧ăo internacional de suporte a econominia brasileira iniciada no fim do ano passado-
sob o impacto da crise financeira Risia pela crise de confianç ue obrigou og

A declaraçáa. de Camdessus foi
nediatamente avalizada por ma forte manifestaçáo de apoie

dos Unidos, Robert Rubin.
dostation. Aplaudimos o importante acor-
do entre o Brasil eo $\mathrm{FMI}$ em torno de um programa econômico ore-
forçado", afirmou Rubin. "O Braforcado", afirmou Rubin. "O Bra-
sil pretende untrapassar tanto as
metas fiscais como de reduçāo dívida acordadas com o Fundo no tantes desde então para alcancar es-
ses objetivos"
O secretário do O secretário do
esouro acrescenPROGRAMA
ou que a "execu-
in firme e sustenada desse progra- COM O FMI TEM a pode preserfinanceira, salvaESTRUTURA MAIS lantes resultados
obtidos sob o Plano Real cassentar
bases solidas para OANTERIOR

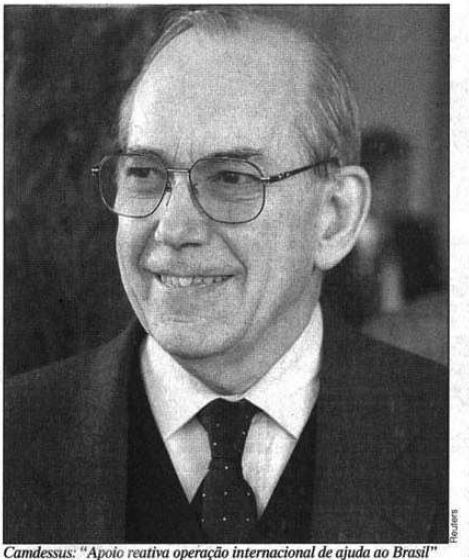
Taxa média real de juros deverá ser de $10 \%$ este ano Taxa foi prevista no anosem prcjudicar a politica monetácordo com o FMI, com ria austera requeridia pela poitica de endência declinante depois de 99 BC, dois fatores vão contribuir para
ILLANA ENRIOUETA LAVOBATII a queda dos juros reais neste ano:

RASilu - as taxas de juros ceitas menos despesas, exceto paga-

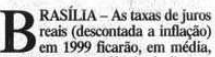
$\mathrm{em} 10 \%$, com tendência declinante $\begin{gathered}\text { Ele lembrou que o o setor público } \\ \text { consolidado - Uniāo, Estados, muni- }\end{gathered}$

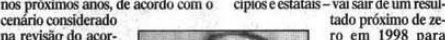
na revisiä do acor-
do como fundo Mo1999. Segundo Fra
netário Internacio-
nal (FMI). Esse ni-
ga a previša de in-

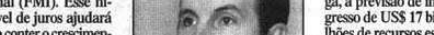
$\begin{aligned} & \text { to da dividas liquida } \\ & \text { de todo o setor públi- }\end{aligned}$
trangeiros diretos
no Pais neste ano re co, que devera pas-
sar de RS 388,6 bi-

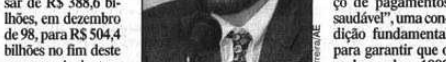
ano - equivalente a
$42,6 \%$ e $49,3 \%$ do segunda parcela do emprest
da instituiçâo, no mes

Esforce-Essa nãoé a única dife-

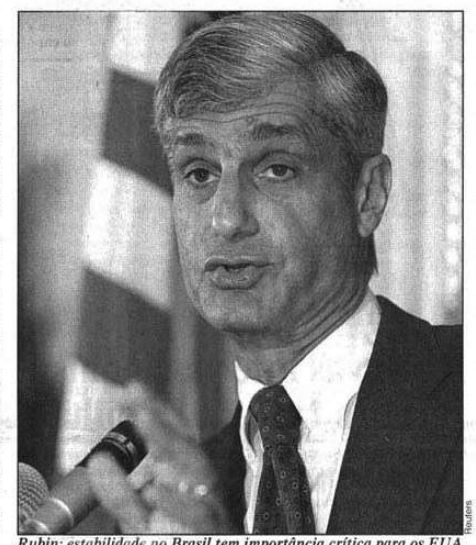
Produto
Brato (PIB). $\begin{gathered}\text { Nash hipotesesem- } \\ \text { butidas no novo } \\ \text { acordo, a taxa Selic }\end{gathered}$
a to presidente do Ban-
coCentral (BC), As$\begin{array}{ll}\text { montem que o Brasil } & \text { SUPORTAM } 20 \%\end{array}$ picáa fundamental
real conclia que o
reg agienta uma taxa O acordo prevè mos, desde que sjam obtidos os supe. montante envolve basicamente as difravits primarios de 3.1\% a 3,35\% do vidas do programa de saneamento
PlB entre 1999 $\mathrm{e} 2001$, saneadas as
dos bancos estaduais assumidas pela contas públicase equilibradoo obalan- Uniáne es passivos do Fundo de

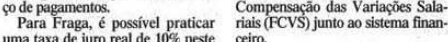

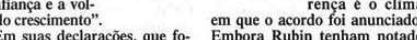
tam distribuídas no momento $e m$ te governo brasileiro divulga- estabilidade no Brasil tem em Brasilia, tanto Camdessus co- para outras ec no Rubin enfatizaram a imporancia da pronta participar mento do Pais. Ambos deixara
clara a disposiçăo do setor ofici de respaldar o governo brasilein

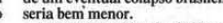
brasileira de uma fonte de pres- real e $\mathrm{o}$ Banco Central liberado
são c abriu o caminho para o Paiss para pôr a politica monetária a Para Tietmeyer, crise da Rússia causou mais danos

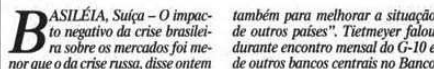

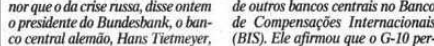
Gria parcial da Rússia, em agosapenas quatrom meses atrás, o Paii
terá agora de fazer um esforço
maior de ajuste das contas do se são cabriu o camininho para o ter uma politica monetária realis- servico do combate à inflacáa
ta e flexivel. Tanto no FMII como num Pais que tomou gosto pela es. na averño de ancricano, predon nubilidade dos precos nos unttimos
tauatro anos, o sentimento domi-
qante no Tesouro e no FMI ́́ $q$ nante no Tesouroe e no FMM Í ́que
o Brasil tem agora uma boa chan tor pubico e produzir um sala
primário de $3,1 \%$ do PIB en
$1999,0 u 0.5 \%$ scar, a partir desta sem seus bancos credores, Camdessus ma frase claramente calculad prometeu a fazer em nuoverbron.
A disposiçá de apoio do To netária nas circunstántaiticas dif. ceis criadas pelo regime cambial quista da credibilidade. "O apoí rir o quanto antes seus cofres pa- regime cambial, por penosa que ce janeiro. regime cambial, por penosa $q$
tenha sido, liberou a econo Com o mercado incumbido externo é importante estará pre-

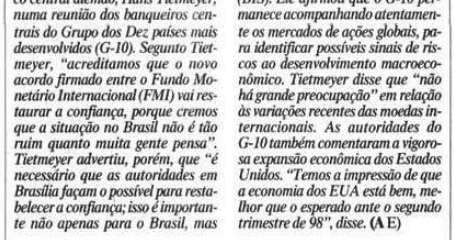

Figura 123. Matérias mostram organismos internacionais opinando sobre o Brasil (OESP, 9/3/1999). Reprodução fotográfica pelo Acervo do Estado de São Paulo. 


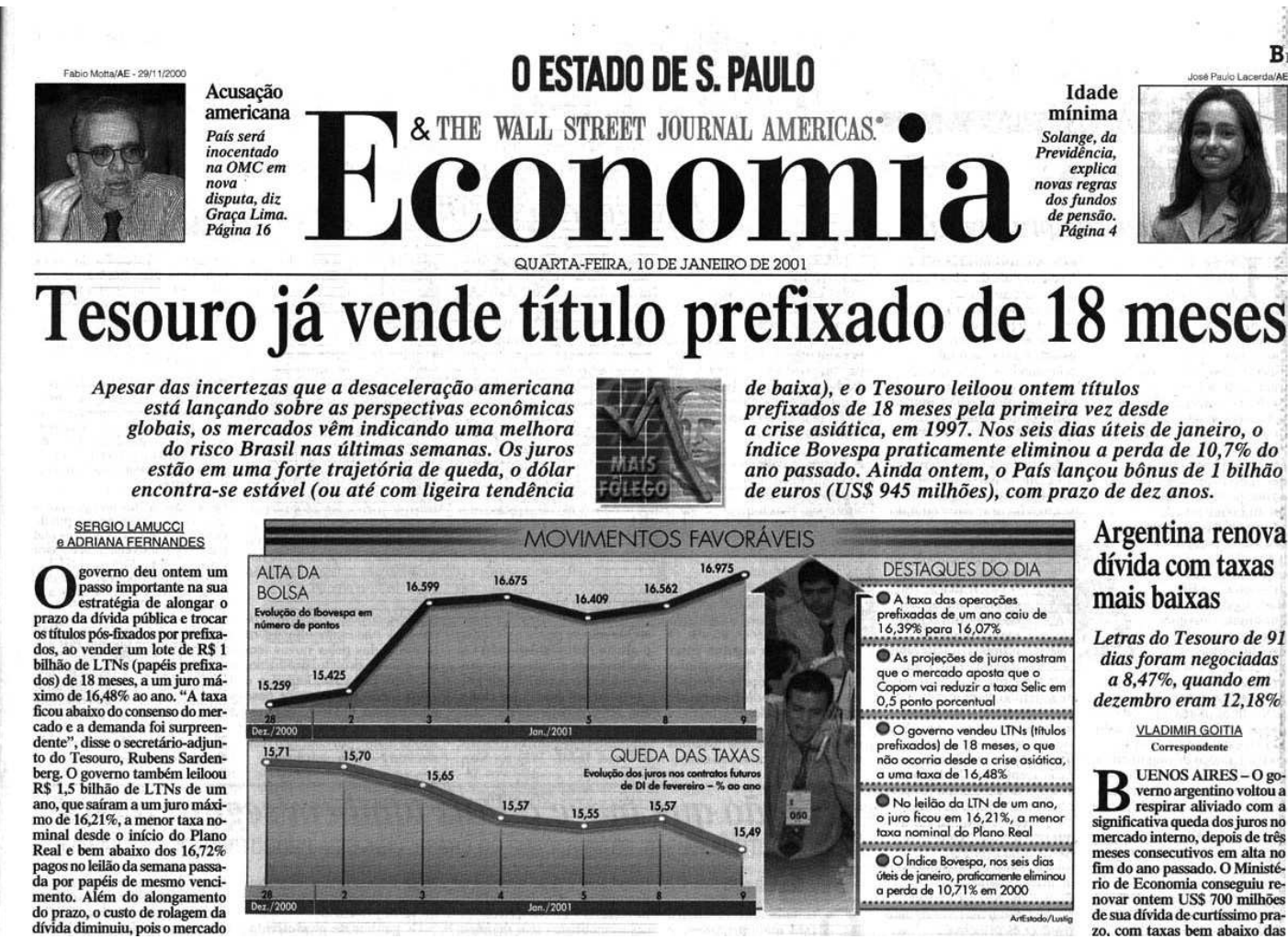

Figura 124. Matéria celebra volta do Brasil ao mercado da dívida (OESP, 10/1/2001). Reproduçẫa fotográfica pelo Acervo do Estado de São Paulo. 


\section{SÁBADO. 10DE ABRIL DE 1999 ECONOMIA \\ OESTADO DE S.PAULO-B? \\ Mercados lucram com tensão nos Bálcãs}
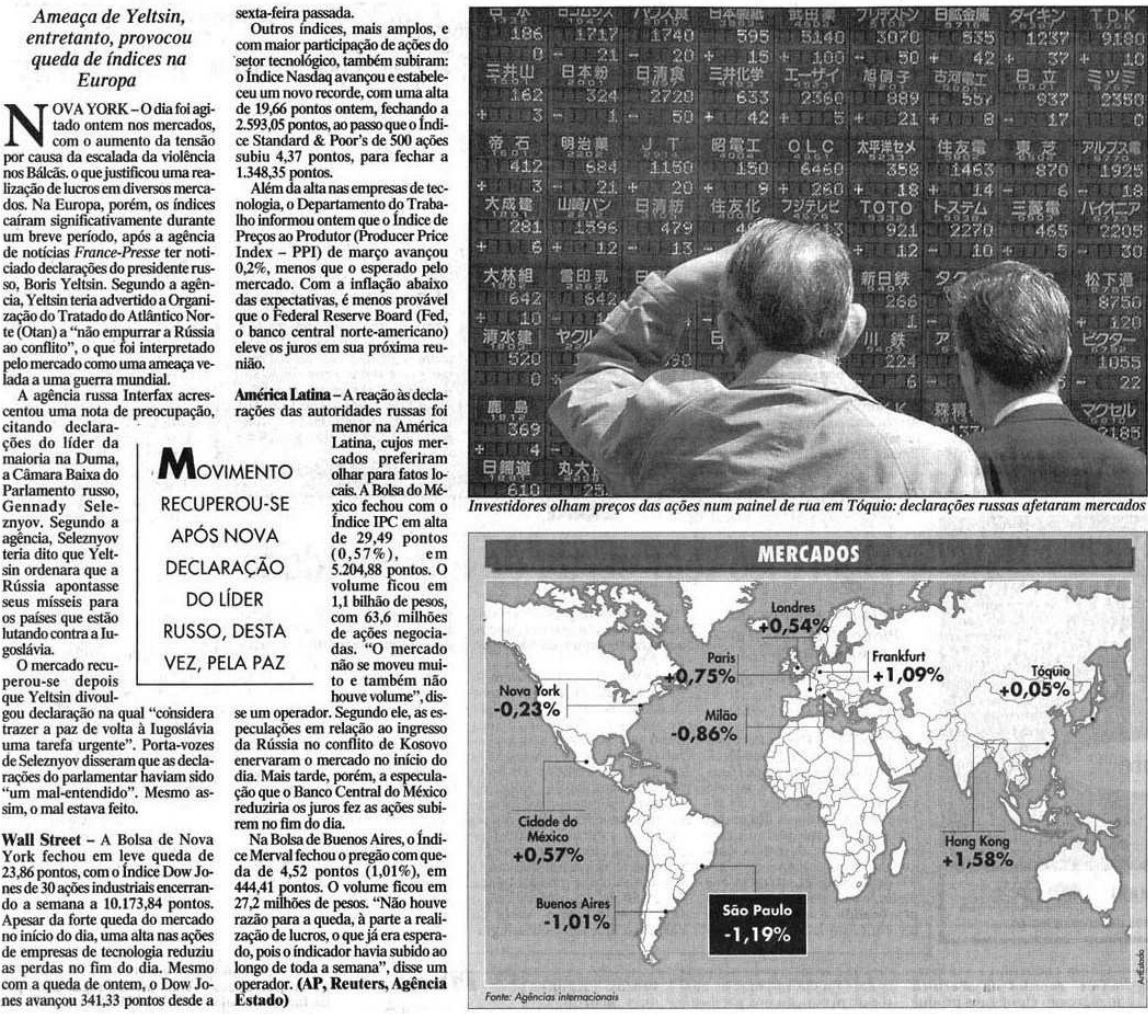

Fusão de bancos desperta atenção do $\mathrm{BC}$ argentino

Os bancos República e Mendonça, controlados reforçamata patrimônió

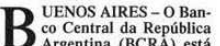
observando de perto dois banceos
controladados por Raul Moneta. nac $T$ The Wall Street Journal. BCRA naia comentao tema, ma
confirma que obanco de ataca. do Banco Repébilica SA e o o Ban-
co de Mendonza SA, ambos de

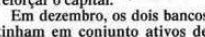
Cinham em conjunto ativos
USS 1,23 bilhäo. Mas uma ond de saques dos clientes que migraram para institiuipós mais sol-
das, sobretudo depois da desvalo rización no Brasili, agravou os
problemas do Banco de Mendoza, um banco de provincia.

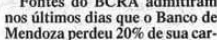
eira de depositos, segundo ojornal Clarin. O presidente
BCRA, Pedro Pou, que há certé de uma semana declarou que
Mendoza estava
ccom um patri-

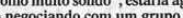
dez bancos de primeira linha $p$ pa ra conseguir uma transterencici.
ordenada do controle da institutui cão provincial. 0 banco ten

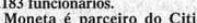
group e da empresa de investMentos norte-americana Hicks

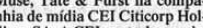
dings SA. A CEI controla um sis os principais canais de televtäa, revistase radios na AArgent-

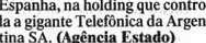

Figura125. Matéria mostra que mercado financeiro lucra com a crise alheia (OESP, 10/4/1999).

Reprodução fotográfica pelo Acervo do Estado de São Paulo. 


\section{Perspectivas para a bolsa ainda são nebulosas}
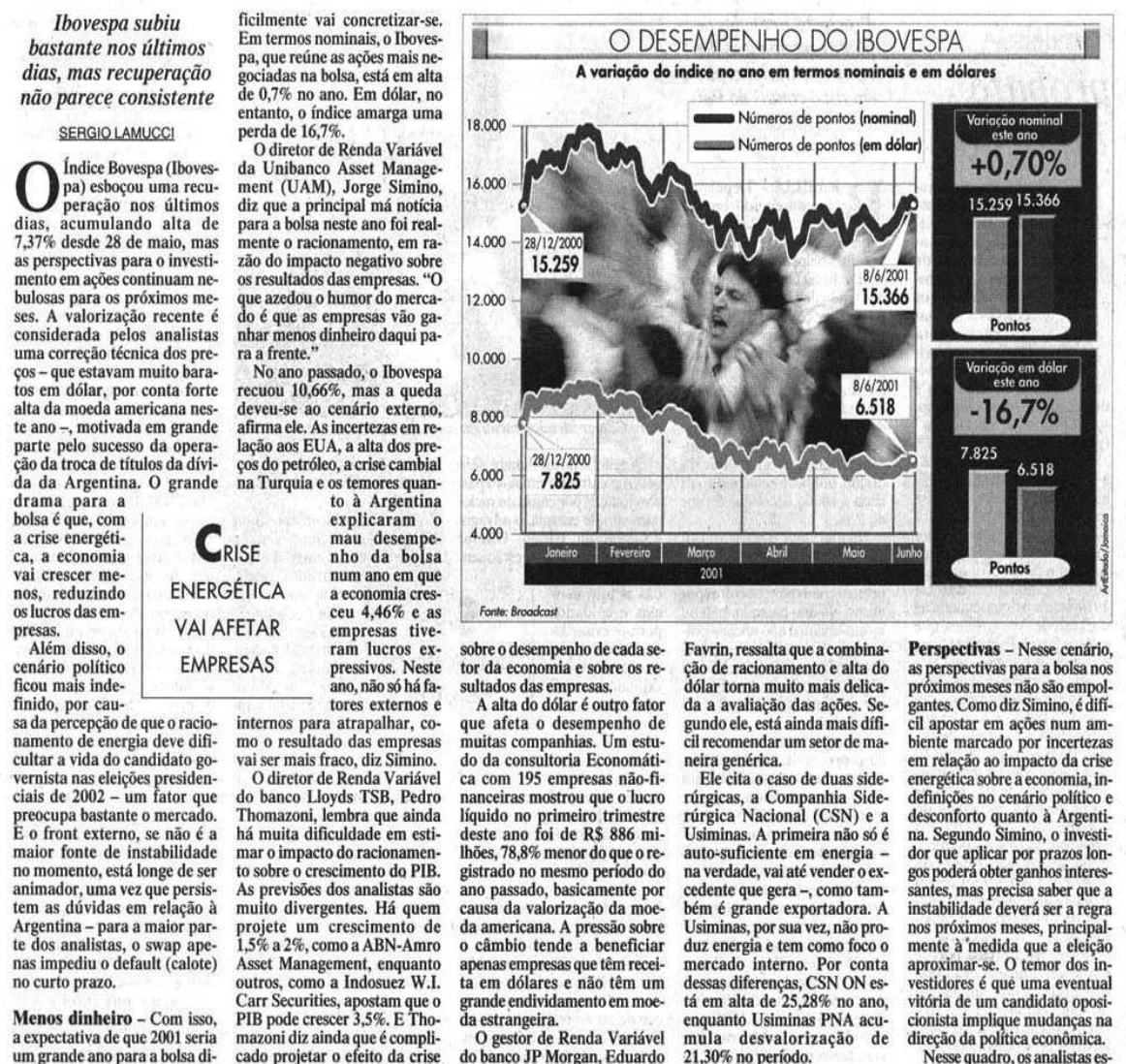

ão revisando para baixo suas retor de Investimentos da BNP Paribas Asset Management, Gil. berto Kfouri Jr., mudou sua projeçấo do indice para o fim pontos, 0 que indica uma pers. pectiva de valorização de ape nas $10,66 \%$ em relação ao nivel
de 15.366 pontos do fechamen. de 15.366 pontos do fechamento de sexta-teira. diretor de Investimentos ment, Alexandre Póvoa, também não vê boas perspectivas
para a bolsa, mas nẫo acreditạ para a bolsa, mas nẫo acredita que o lbovespa va recuar con vosé que a alta do câmbio motrteia as açóes em dólar. E os preços dos papéis brasileiros estão especialmente atrativos se comcanas. Enquanto o lovesp canas. Enquanto o lbovespa lares neste ano, a Bolsa da Cidade do México registra alta de 20\%, empurrada tanto pela valorizaçâo nominal das açoesco. à pela a dos Estados Unidas Esse descompasso levou o banco JP Morgan a recomendar sobre o desempenho de cada se- Favrin, ressalta que a combina- Perspectivas - Nesse cenário, $\begin{aligned} & \text { aos clientes o aumento da expo- } \\ & \text { or da economia e sobre os re- }\end{aligned}$ ção de racionamento e alta do as perspectivas para a bolsa nos
sicăo no mercado acionário braor da economia e sobre os re- çáo de racionamento e alta do as perspectivas para a bolsa no A alta do dólar é outro fator da a valiaç̃o das acōes Se- gantes. Como di Simino, édifique afeta o desempenho de gundo ele, está ainda mais dífi. cil apostar em acôes num ammuitas companhias. Um estu- cil recomendar um setor de ma- biente marcado por incertezas do da consultoria Economáti- neira genérica. em relação ao impacto da crise ca com 195 empresas não-fi-
nanceiras mostrou que cita o caso de duas side- energética sobre a economia, in-
rúrgicas, a Companhia Side-
definiçóes no cenário politico nanceiras mostrou que olucro rúrgicas, a Companhia Side-
líquido no primeiro trimestre rúrgicáces no cenário politico e
rucional (CSN) e a
desconforto quanto à Argentideste ano foi de R\$ $886 \mathrm{mi}$ - Usiminas. A primeira não só é na. Segundo Simino, o investiihōes, $78,8 \%$ menor do que o re- auto-suficiente em energia - dor que aplicar por prazos lon-

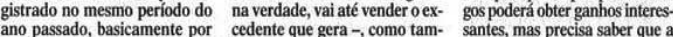
ano passado, basicamente por cedente que gera -, como tam- santes, mas precisa saber que da americana. A pressão sobre Usiminas, por sua vez, não pro- nos próximos meses, principalcâmbio tende a beneficiar duz energia e tem como foco 0 mente à'medida que a eleiçầ

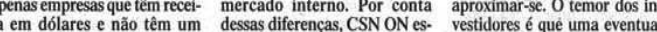
a em dólares e não têm um dessas diferenças, CSN ON es- vestidores é que uma eventua
grande endividamento em moe. tá em alta de $25,28 \%$ no ano, vitória de um candidato oposisileiroe a redução da aposta en Operadores notaram a presença de investidores estrangeros na ponta de compra nos últmos dias, A questão é que esse sivo, não deve dar sustentacia a alta das cotaçoes. Para Thomazoni, essas compras são esp 0 investidor doméstico, por especialmente depois do surg. mento da crise energética surger ção das aplicaçōes de renda fixa voltou a atrapalhar bastante. A taxa Selic, hoje em $16,75 \%$ enquanto Usiminas PNA aç
mula gestor de Renda Variálorização de Nesse quadro, os analistas es ao ano, ja subiu 1,5 ponto por-
centual nos últimos trếs meses.

Figura 126. Matéria traz projeções sobre o comportamento futuro da bolsa de valores brasileira (OESP, 10/6/2001). Reprodução fotográfica pelo Acervo do Estado de São Paulo. 


\section{Ricupero reduz mais tarifas de importação}

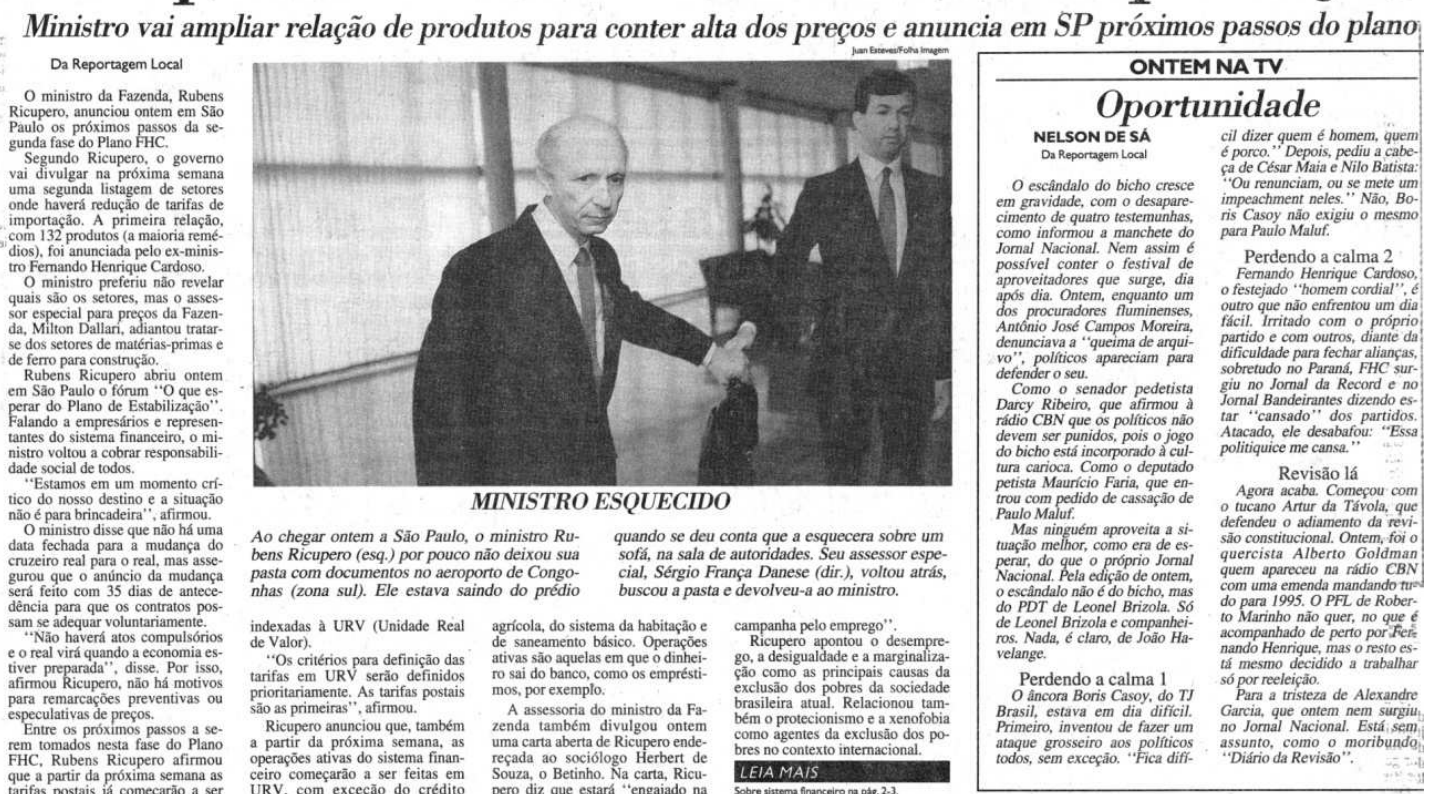

Figura 127. Ministro anuncia novas medidas do Plano Real (FSP, 9/4/2001). Reprodução fotográfica pelo Acervo do Estado de São Paulo. 


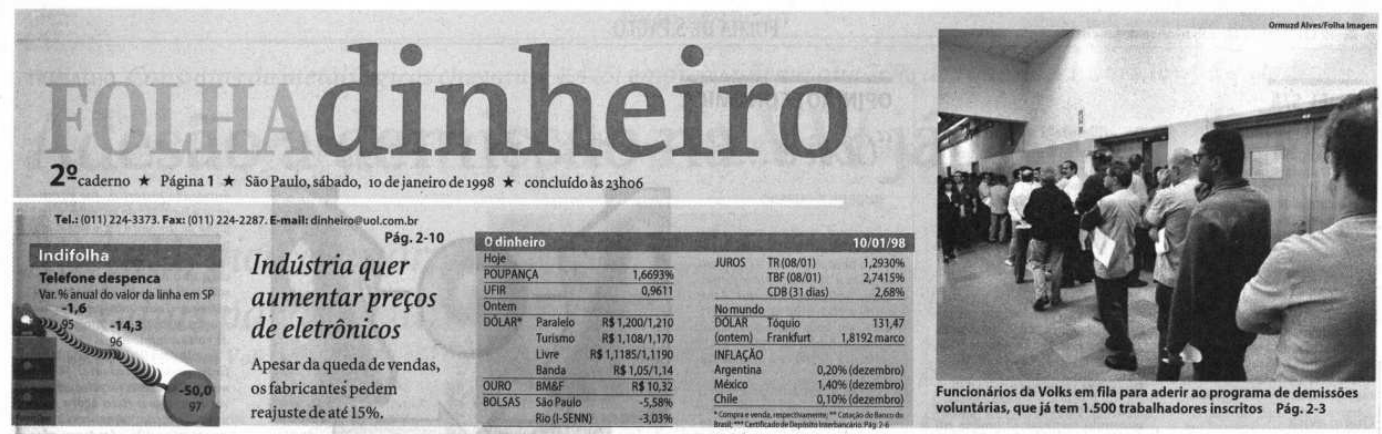

CRISE ASIÁTICA Iniciativa de Clinton acalma mercado de câmbio na Ásia, mas não evita forte queda das Bolsas de Valores Indonésia precipita novo crash global

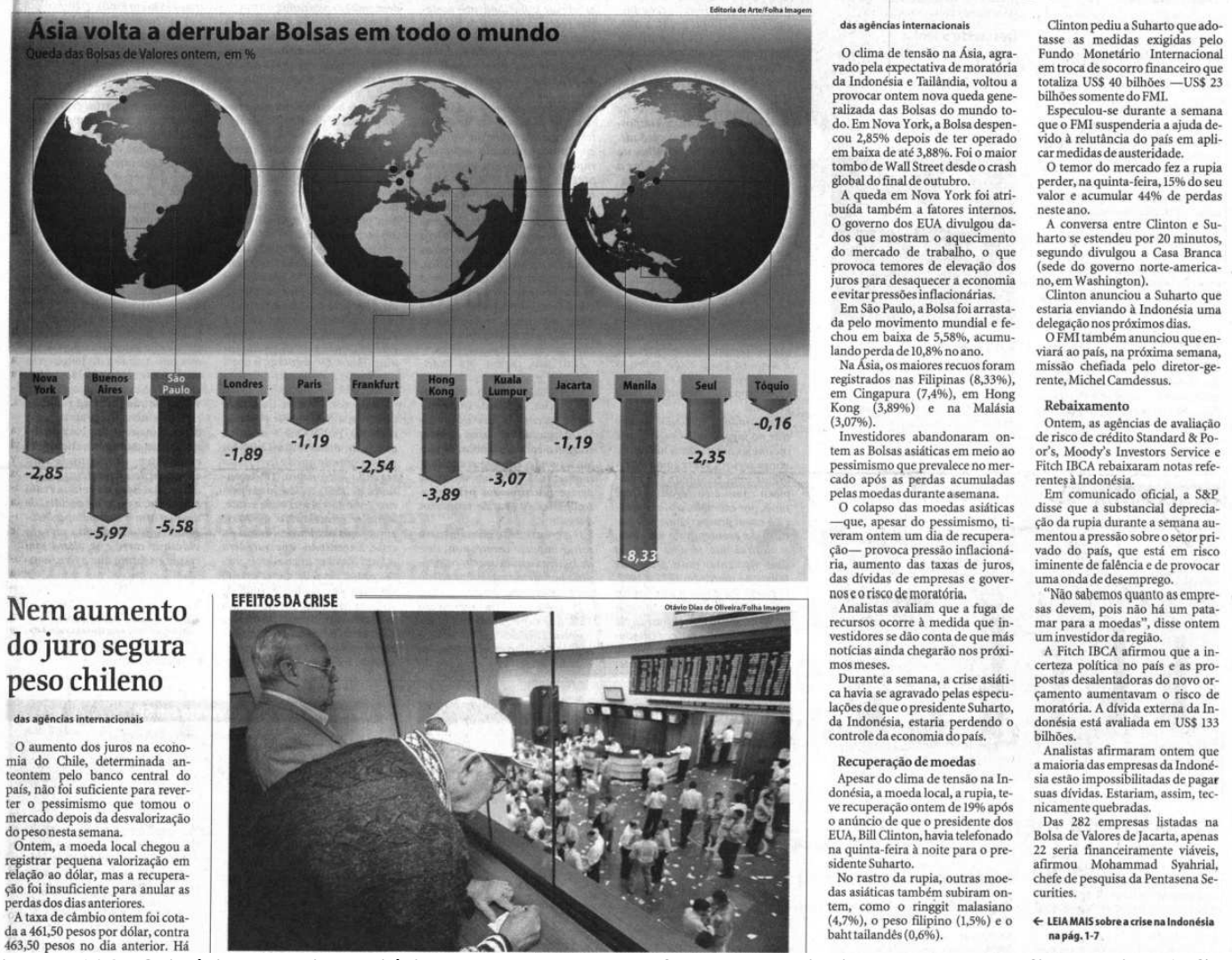

Figura 128. O início da crise asiática, provocada por fuga de capitais do mercado financeiro (FSP, 10/01/1998). Reprodução fotográfica pelo Acervo do Estado de São Paulo. 


\section{Setor elétrico será dividido para venda \\ Documento prevê o desmembramento da Eletrobrás para a privatização de suas subsidiárias uma a uma}
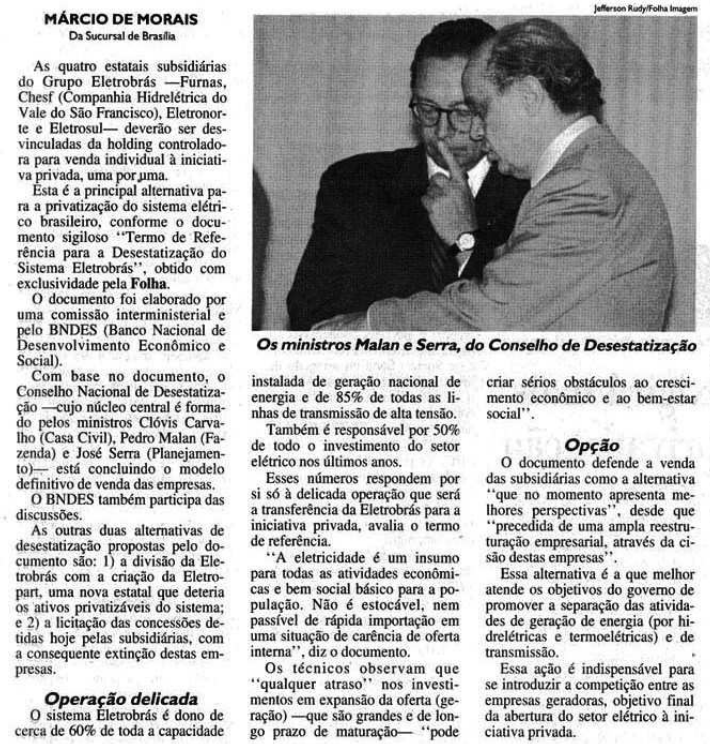

instalada de geracăo nacional de
energia e de $85 \%$ de todas as li-

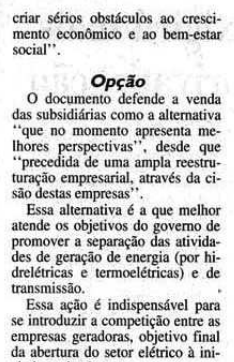
Também é responsável por 50 \%

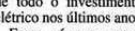

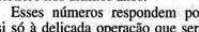

si só dè delicada operąąa que sera

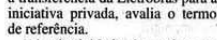

para todas as atividades econômi-
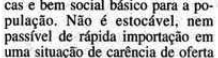

interma", diz o documento.
Os técnicos observam que

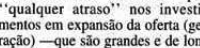

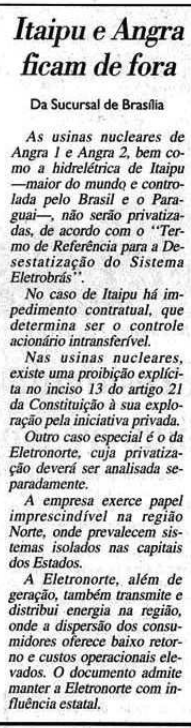

NOAR

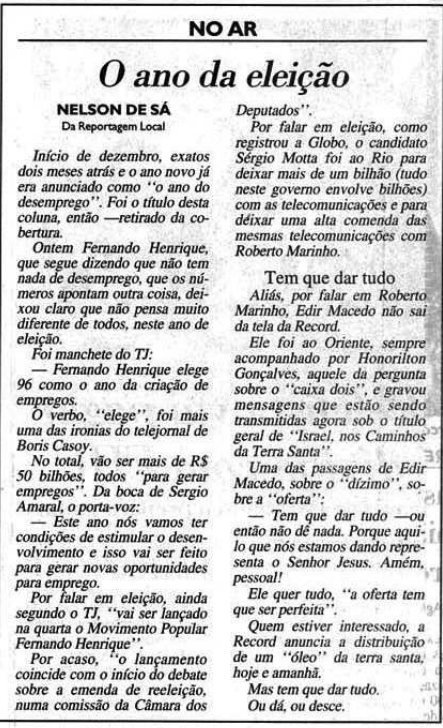

Figura 129. Anúncio pela imprensa de modelo de privatização do setor elétrico (FSP, 10/6/1996). Reprodução fotográfica pelo Acervo do Estado de São Paulo. 
São Paulo, terça-feira, 10 de fevereiro de 1998

País obtém US\$543 mi no primeiro lançamento de títulos após a crise asiática, que, para Malan, ainda trará um ano de incerteza Brasil capta dinheiro no exterior

Turquia já age para deter fuga do Iraque o Exército da Turquia lançou operaçăo no norte do Iraque
para deter um provível fluxo de refugiados curdos para seu território no caso de ofensiva norte-americana contra Bagdá.
$O$ governo dos EUA intensificou sua escalada militar no golfo Pérsico. O Pentágono informou que está enviando mais
3.000 soldados para o Kuait, 3.000 soldados para o Kuait,

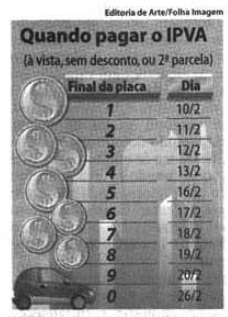
IPVA 98 Começa a vencer hoje o prazo para quitar o imposto
sem desconto em SP Pág. 2-2

Covardiáe o traço notável da elite do país ROBERTO MANGABEIRA UNGER

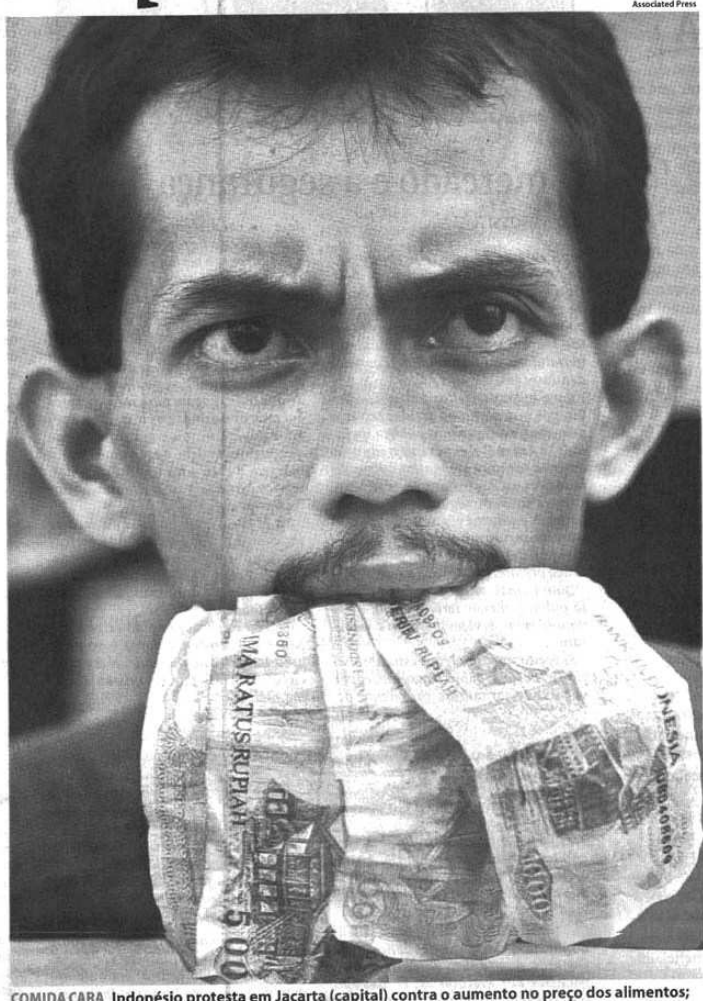

O. Banco Central vendeu on- $\begin{gathered}\text { A taxa, porém, é menor do } \\ \text { que a obtida pela Argentina em }\end{gathered}$ em bónus da República. Foi a lançamento há duas semanas. primeira captaçäo internacio- A volta do Brasil ao mercado A operaçáo significa aumento nejada há duas semanas pelo $\begin{array}{ll}\text { A divida externa, mas a inten- } & \text { Banco Central, como um teste } \\ \text { câo do governo é mostrar ao } & \text { para checar como os investido- }\end{array}$ çäo do governo é mostrar ao externo que o pass tom crestáa vendo o páís. ca. Os bônus serāo resgatados o ministro Pedro Malan ( $\mathrm{Fa}$ em 2003, a juros de 8,625\% ao zenda) disse que, "pelo menos $\begin{aligned} & \text { ano }- \text { superiores aos vigentes } \\ & \text { antes da crise de outubro. }\end{aligned}$
grau de incerteza". Pág. $2-1$

Sucesso não muda o risco do Brasil

cisopinto

o custo, maior o risco. Na do Conselho Editorial comparação de papéís emitium sucesso, mas não mudou a lhante, o custo do pais é maior percepçăo do mercado sobre o que o de Venezuela, Argent

Afastado Metrô pode delegado parar em que explora ato contra segurança Previdência A Corregedoria da Polícia
Civil de São Paulo afastou o ovírios devem atrasar
hoje, das $5 \mathrm{~h}$ para as $6 \mathrm{~h}$, o início $\begin{array}{ll}\text { Civil de São Paulo afastou o } & \text { hoje, das } 5 \mathrm{~h} \text { para as } 6 \mathrm{~h} \text {, o inicio } \\ \text { delegado Joffre Sandin. Encar- } & \text { da circulação dos trens em }\end{array}$ delegado loftre Sandin. Encar-
regado de apurar irregularida-
protesto contra a reforma da des na corporação, eleé um dos Previdência, que tem votaçào policiais paulistas que dirigem na Camara prevista para amaempresas de segurança, como nha. Segundo sinatcato dos revelou a Folla. Ea trética do momerar circular śd ds 6 h Sandin enviou carta à corre- A CUT e entidades de servi$\begin{array}{ll}\text { gedoria pedindo afastamento } & \text { dores pretendem colocar } 3.000 \\ \text { - que ja havia sido determina- } & \text { pessoas amanhă em frente ao }\end{array}$ do- para, segundo ele, facili- Congresso, que será cercado

Matrículas

Figura 130. Brasil volta a vender títulos da dívida no mercado financeiro internacional, pagando juros altíssimos (FSP, 10/2/1998). Reprodução fotográfica pelo Acervo do Estado de São Paulo. 


\section{FOLHA DE S.PAULO}

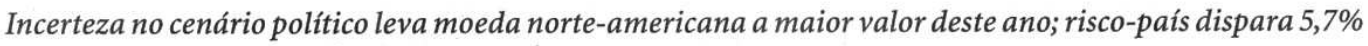

\section{Dólar vai a R \$2,47; Bolsa cai 4,08\%}

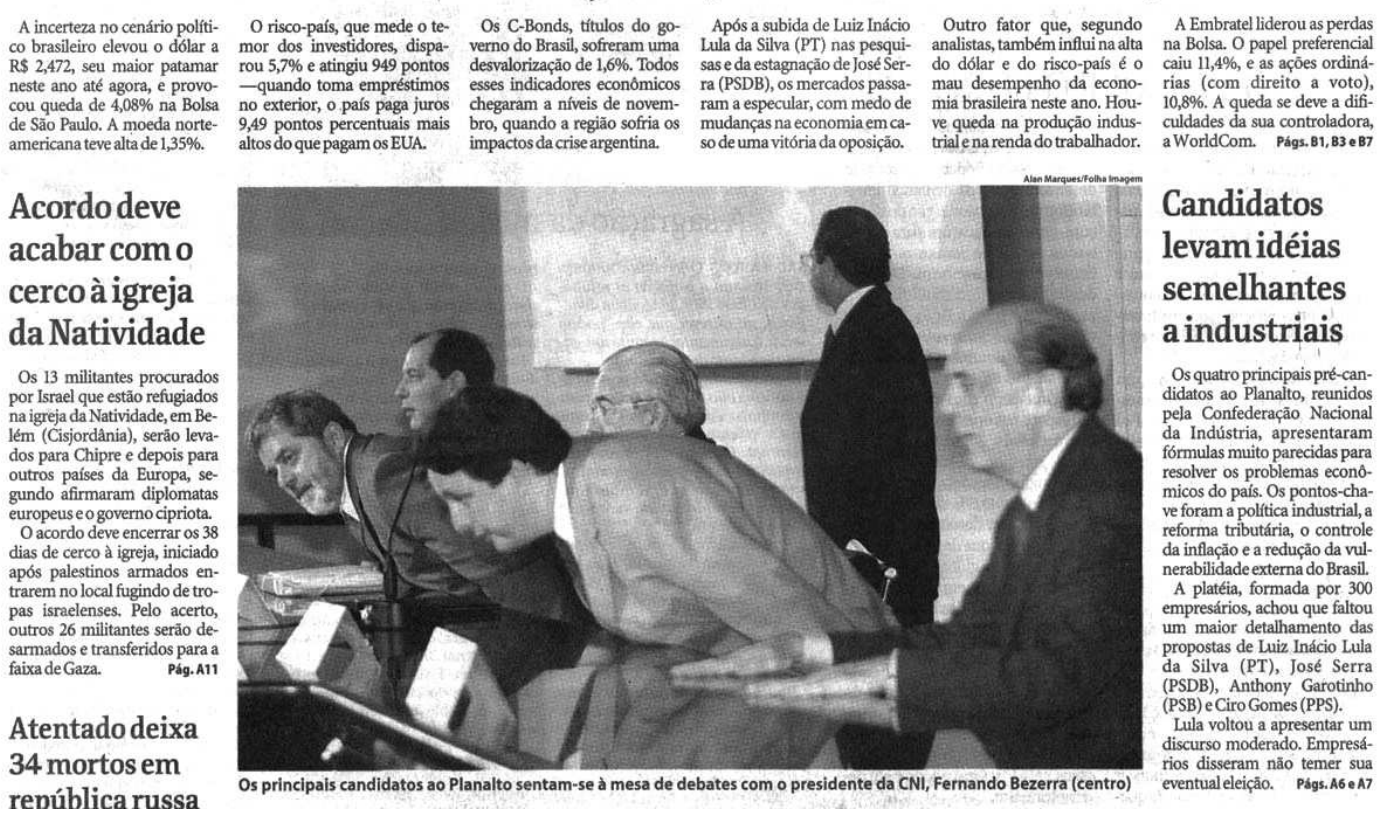

Figura 131. Comportamento do dólar e da bolsa são o que de mais importante há para ser noticiado sobre o Brasil , quando a disputa pela eleição presidencial já mostra favoritismo de Luiz Inácio Lula da Silva. Mercado financeiro teme Lula no Planalto e ensaia fugir do País (FSP, 20/5/2002). Reprodução fotográfica pelo Acervo do Estado de São Paulo. 


\section{ANEXO B}

Exemplo de relatório de banco enviado gratuitamente a jornalistas.

\section{CREDIT SUISSE}

\section{CREDIT SUISSE HEDGING-GRIFFO}

HIGHLIGHTS

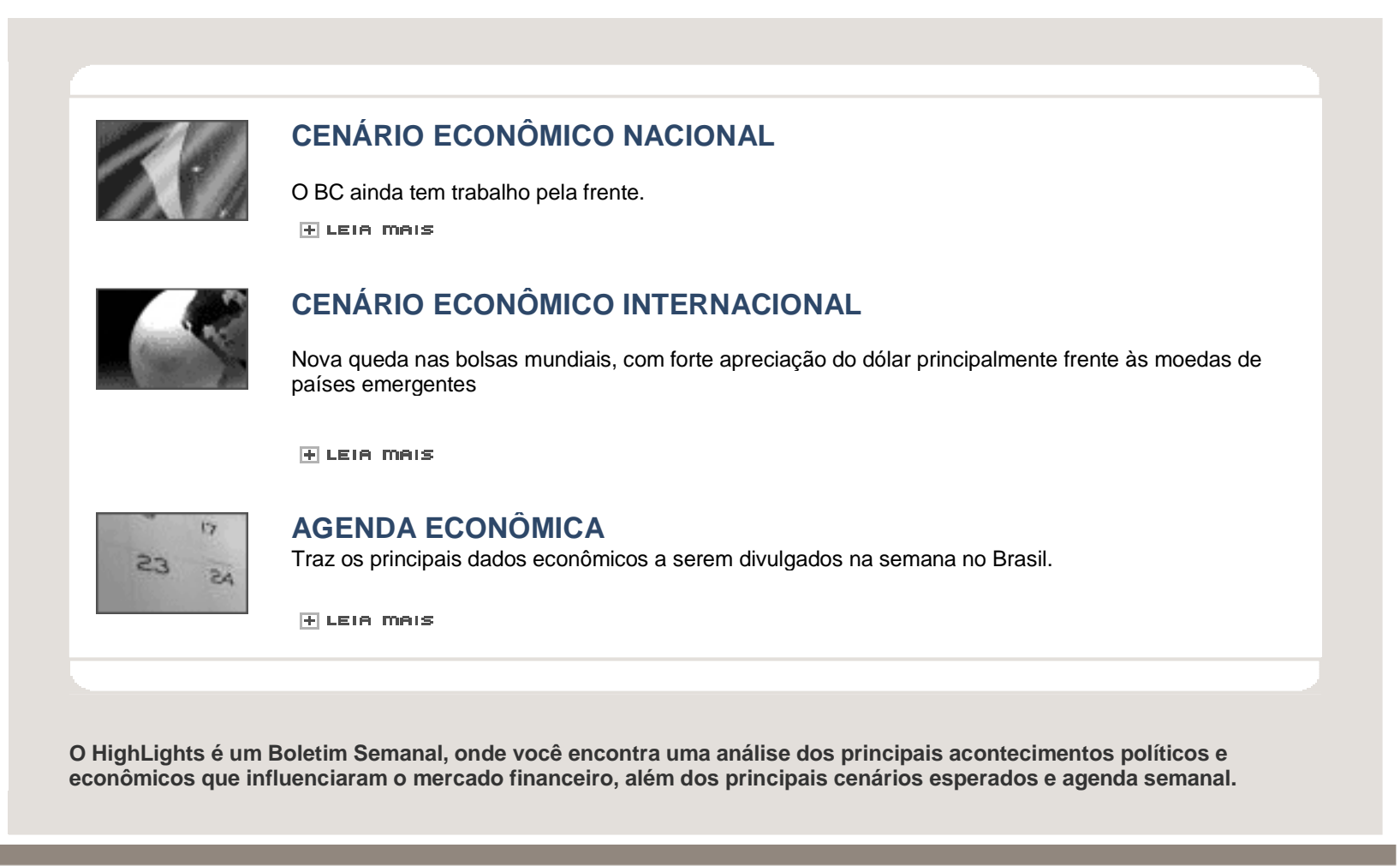




\section{CENÁRIO NACIONAL}

Temos mais uma reunião do Copom nesta semana. A despeito da evidente melhora na inflação corrente seguimos esperando que o aumento seja, novamente, de 75 pbs (é também o consenso no mercado) e que o ritmo de 50 pbs seja retomado na reunião de outubro.

Talvez a razão mais importante para essa projeção seja o que, avaliamos, levou o comitê a optar pela aceleração na reunião de Julho. Lá o risco era a rápida abertura de expectativas, especialmente as de 2009, motivada tanto pelos choques em preços importantes (commodities agrícolas, especialmente) que atingiam a economia quando a demanda estava acelerando. Foi o risco de perder a ancoragem nas expectativas que levou o Copom a elevar o ritmo. Era um sinal de que ele combateria ativamente a inflação mais alta. Nessa linha também, o BC tem deixado claro, sempre que pode, que seu objetivo é trazer a inflação de 2009 para $4,5 \%$. Os sinais e a comunicação importam aqui.

É verdade que, nesses últimos dias, um componente importante desse argumento perdeu força. A queda nas commodities nos mercados globais nesses últimos meses está trazendo a inflação doméstica rapidamente para baixo. Por isso, o IPCA de agosto já veio tão mais baixo $(0,28 \%$ contra $0,53 \%$ de julho). Sem dúvida, é uma ótima notícia; mas a dúvida é se isso basta.

Por enquanto, parece que não. Primeiro porque a avaliação do $B C$ é que o cenário global segue coberto de incertezas e que não necessariamente o menor crescimento global (que está por trás dessa realização nas commodities) ajudará a trazer nossa inflação doméstica para baixo. Afinal, um arrefecimento na demanda por commodities pode desequilibrar o balanço de pagamentos do país e colocar o câmbio em outro patamar, o que pressionaria a inflação de tradables, mesmo em um ambiente de queda nos preços das commodities. O comportamento do câmbio nos últimos dias só ajuda a mostrar que essa ambiguidade, realmente, existe.

Nossa visão é que, realmente, a desaceleração do crescimento global, em um ambiente de rápida deterioração da conta corrente, vai demandar uma correção para o câmbio. Mas, por mais que esse processo venha carregado de volatilidade, o ajuste, na nossa projeção é modesto (já abordamos esses pontos há alguns dias e vamos voltar a ele nas próximas semanas). Na nossa projeção um câmbio próximo a $\mathrm{R} \$ 1,75$ equilibra o balanço de pagamentos. Seu efeito inflacionário seria baixo e a correção global no valor do dólar está sendo um catalisador importante para que esse equilíbrio venha ainda neste ano. Minimiza, portanto, os efeitos para 2009, o que não deixa de ser positivo para os objetivos do BC. Se estivermos corretos nessa projeção, a queda recente das commodities, portanto, reduz as pressões inflacionárias.

Mas, é compreensível que o BC espere um pouco mais antes de repercutir essa avaliação positiva 
em suas ações. Afinal, essas relações não são assim tão lineares e, uma queda muito mais profunda das commodities (sinalizando uma recessão global profunda, por exemplo) poderia ter um efeito maior sobre o câmbio. Parece o caso do BC esperar um pouco antes de modificar sua postura.

Outro argumento, este mais importante, para que o BC mantenha a cautela é o comportamento da atividade. Aqui também há sinais preliminares de mudança, mas eles ainda parecem incipientes para que o BC modifique suas escolhas. De um lado, a demanda começa a mostra sinais de desaceleração. O mercado de crédito está contraindo e as vendas de veículos de agosto mostram que os setores mais cíclicos estão começando a recuar, como previsto. Por outro lado, a indústria segue mostrando vigor. É verdade que está difícil analisar o comportamento da indústria pela diferença nos dias úteis (a ausência de feriados faz com que $2^{\circ}$ semestre tenha 5 dias úteis a mais do que no ano passado); mas também é fato que os setores ligados à construção civil e à industria extrativa estão acelerando nesse período. A construção civil reflete a expansão das vendas do setor desde o fim do ano passado; já a indústria extrativa é resultado dos investimentos do setor nesses últimos anos devido ao longo ciclo favorável das commodities. O dinamismo, portanto, reflete decisões passadas, o que reduz um pouco a ciclicalidade da indústria.

Se somarmos essas evidências, parece que a economia está se posicionando para uma desaceleração mais clara a partir do último trimestre. A demanda externa está indo rapidamente para baixo e o consumo doméstico está, aparentemente, perdendo dinamismo a começar pela demanda de duráveis que, realmente, é mais cíclica. A desaceleração da indústria será mais gradual, porque há setores em que as defasagens estão maiores; mas ela vem.

Mas, novamente, não parece que o BC vai antecipar essas conclusões na sua decisão desta semana. Há dúvidas, por exemplo, se a indústria e a construção civil mais fortes não pressionariam para cima o mercado de trabalho evitando a queda que esperamos na demanda. Não há duvida que este é um risco importante; consideramos esse desfecho improvável, mas é razoável que o $\mathrm{BC}$ tenha uma aversão maior a comprar nossa história já.

Finalmente, talvez a principal razão para que o $\mathrm{BC}$ mantenha o ritmo é a resistência das expectativas. A pesquisa Focus do BC mostra que, a despeito da queda na inflação esperada para 2008, as projeções para 2009 seguem paradas em 5,0\%. Pior que isso: nesta última semana, 0 $\mathrm{BC}$ divulgou também a distribuição dessas expectativas e estas mudaram muito pouco, mesmo com os números melhores na inflação corrente. Parte relevante do mercado projeta um IPCA de 2009 bem acima de 5,0\%. Talvez isso esteja relacionado ao risco da inflação passada ser repassada com intensidade para os preços regidos por alguma forma de contrato. Estamos vendo dentro do IPCA um aumento mais significativo nos reajustes de alugueis. Também no mercado formal de trabalho, os dissídios estão vindo mais elevados. Tudo isso dificulta a queda da inflação e pode tornar o trabalho do BC mais custoso.

Nos próximos meses, os dois pontos que esperamos devem ficar mais claros. O efeito líquido da queda do preço das commodities e do câmbio trará uma percepção de que os riscos da inflação de tradables é menor para 2009. Também no decorrer do período, a atividade deve mostrar sinais um pouco mais concretos de desaceleração. Pode ser o suficiente para, se não deslocar para baixo a mediana das expectativas para 2009, pelo menos para reduzir a "moda mais alta"; ou seja, para concentrar as expectativas em torno de um numero mais próximo do centro da meta. Um sinal de estabilidade, que bastaria para o BC voltar aos 50 pbs. Mas só em outubro.

Mais adiante, se estivermos corretos em relação ao timing de desaceleração da atividade é bem provável que, na virada do ano, o BC já esteja mais confortável em relação ao ritmo de expansão da demanda. É por isso que projetamos que o último aumento venha no Copom de dezembro 
(ainda que reconheçamos um risco razoável para janeiro). Estamos, em suma, nos aproximando do fim do ciclo. Mas, o BC ainda tem trabalho pela frente.

\section{Elsom Yassuda elsom.yassuda@cshg.com.br Fernanda Batolla AGENDA ECONÔMICA fernanda.batolla@cshg.com.br Daniel Ribeiro Leichsenring daniel.ribeiro@cshg.com.br Raone Botteon Costa raone.costa@cshg.com.br}

BRASIL

Indicadores Econômicos - 08 a 12/09/2009

\begin{tabular}{clcccc}
\hline Dia & Indicador & Período & Anterior & Projeção & Consenso \\
\hline 8/set & IPC-S (FGV) 8:00 & Ago & $0.14 \%$ & - & - \\
8/set & IGP-DI (FGV) 8:00 & Ago & $1.12 \%$ & $-0.20 \%$ & $-0.20 \%$ \\
8/set & Expectativas IPCA (BCB - Focus) 8:30 & 2008 & $6.32 \%$ & - & - \\
8/set & Balança Comercial Semanal (MDIC) 11:00 & Ago & $-\$ 840 \mathrm{M}$ & - & - \\
10/set & IPC (Fipe) 7:00 & Set & $0.35 \%$ & - & - \\
10/set & IGP-M (FGV) 1a Prévia 8:00 & Set & $-0.01 \%$ & $0.05 \%$ & - \\
10/set & PIB (IBGE) YoY 9:00 & 2T08 & $5.80 \%$ & $5.50 \%$ & $5.50 \%$ \\
10/set & PIB (IBGE) QoQ 9:00 & 2T08 & $0.70 \%$ & $1.20 \%$ & $1.10 \%$ \\
10/set & PIB (IBGE) Acumulado 4 Trimestres 9:00 & 2T08 & $5.80 \%$ & $5.80 \%$ & - \\
10/set & Taxa Selic (BCB) 18:00 & Set & $13.00 \%$ & $13.75 \%$ & $13.75 \%$ \\
\hline
\end{tabular}

\section{COMENTÁRIOS}

IGP-DI - Ago/08: A inflação no atacado ainda permanecerá no terreno negativo na apuração do IGP-DI de agosto, ainda influenciada pela deflação dos preços agrícolas (seguindo à queda de importantes commodities agrícolas, especialmente os grãos). Essa queda terá impactos sobre a parte industrializada do IPA. Entretanto, cabe ressaltar que o auge da deflação dos preços agrícolas deve ter ficado para trás, com efeitos menores nas próximas apurações do IGP. Neste sentido, a primeira prévia do IGP-M de setembro já deve mostrar uma deflação bem mais moderada.

PIB - 2T08: Deverá registrar crescimento de 5,5\% YoY e de 1,2\% MoM 
Dessaz. Esse resultado representa uma aceleração na margem, pois no 1T08 tivemos uma expansão de $0,8 \%$. Do lado da oferta, o principal destaque será o PIB industrial (em especial construção civil e transformação) e de serviços. Do lado da demanda, tanto os investimentos (14,7\% YoY) quanto o consumo das famílias deverão manter o patamar elevado de crescimento. Como já comentamos, o PIB de 2008 deverá ficar em 5,0\% em 2008, acima do esperado anteriormente, beneficiado pelo desempenho verificado no $1^{\circ}$ semestre $(5,8 \%$ sobre o mesmo período de 2007). Isso significa que o PIB no $2^{\circ}$ semestre vai desacelerar para 4,3\%, puxado principalmente pelo arrefecimento do consumo. E esta desaceleração prosseguirá ao longo de 2009, quando o PIB irá recuar para $3,4 \%$.

Taxa Selic - Set/08: Desde a última reunião, houve melhora no quadro inflacionário, especialmente no que concerne à inflação de curto prazo. A reversão dos preços agrícolas também fez o IPCA recuar de maneira importante, trazendo as expectativas para 2008 de IPCA de volta para dentro do intervalo de metas, ainda que as expectativas para 2009 tenham permanecido no patamar de 5,0\%. Por outro lado, os números de atividade continuaram a mostrar crescimento robusto, sem muitos sinais consistentes de desaceleração. Adicionalmente, o cenário externo tornou-se ainda mais incerto ao longo das últimas semanas, com desdobramentos importantes sobre a taxa de câmbio. No final, o fator determinante será o ritmo de atividade, que fará o BC prosseguir no passo de 0,75 p.p. 


\section{ANEXO C}

Exemplos de comunicados (releases) de assessorias de imprensa sugerindo fontes, oferecendo cursos e prêmios aos jornalistas. Material recebido por email pela pesquisadora.

\section{HISTÓRIA - APÓS UM ANO DE FORTE QUEDA A TENDÊNCIA É UMA FORTE ALTA}

Paula, segue abaixo um comentário do Decio Pecequilo sobre o pessimismo que toma conta do mercado.

"É nítido que vivemos um ano complicado porém após 40 anos de mercado financeiro aprendi que dias melhores virão, e que o pessimismo não contribui para o sucesso no mercado financeiro.

Apesar de muitos comentarem que nunca viram uma crise igual, a história mostra que este ano não é o pior de todos os tempos, como exemplo podemos citar 1987 onde o índice BOVESPA caiu - 71,99\% ou ainda 1990 quando a queda foi de 72,73\%.

Porém, o mais importante não foram os recordes negativos e sim os anos posteriores a estes quando foi registrado as maiores altas da história da bolsa mostrando assim que após as turbulências, historicamente o mercado se recupera de forma agressiva como em 1988 e 1991 apresentando altas de 151,14\% e 288,63\% respectivamente.

Ontem, foi o Dia de São Judas Tadeu o santo das causas perdidas e tivemos um dia de forte alta, momento importante após 5 fechamentos negativos consecutivos.

No acumulado em 2008 o índice Bovespa perde 47,7\%, algo distante dos piores índices históricos e demonstrando que sempre sairemos do fundo do poço."

Por Decio Pecequilo operador sênior da TOV Corretora.

Se precisar falar com o Décio por gentileza me ligue.

um abraço, 


\section{Inscrições abertas para o curso Introdução ao Mercado de Capitais do Ação Jovem}

O Ação Jovem do Mercado Financeiro e de Capitais promove nos dias 11 e 13 de agosto, das 19h às 22h30, no Auditório I da Bovespa, o curso Introdução ao Mercado de Capitais - Módulo I. Dirigido a estudantes e profissionais de qualquer área que desejam entender melhor o funcionamento deste mercado, o curso é ministrado pelo administrador de empresas e conselheiro do Ação Jovem José Augusto Miranda. Introdução ao mercado de renda variável, tendências macro-econômicas, estruturação do mercado financeiro, bolsa de valores e corretoras, análise fundamentalista e governança corporativa estão entre os temas abordados. Haverá ainda uma simulação de um pregão viva-voz.

As inscrições podem ser feitas até 07/08, pelo e-mail ajmc@ajmc.com.br ou pelo telefone (11) 3188 7252. O investimento é de R \$120,00. As vagas são limitadas.

\section{Sobre o Ação Jovem do Mercado Financeiro e de Capitais}

Fundando em 2003, o Ação Jovem do Mercado Financeiro e de Capitais é uma associação sem fins lucrativos que visa a desmitificar e aproximar as novas gerações do mercado financeiro e de capitais, contribuindo para o fortalecimento dos mercados, das empresas e do próprio País. O grupo, com sede em São Paulo, tem mais de 4,2 mil associados, e, em seus eventos, já contou com participações de Fernando Henrique Cardoso, Armínio Fraga, Gustavo Franco, entre outros.

\section{Serviço:}

\section{Curso Introdução ao Mercado de Capitais}

Data: 08 e 10 de julho (terça e quinta-feira)

Horário: $19 \mathrm{~h}$ às $22 \mathrm{~h} 30$

Investimento: $\mathrm{R} \$ 120,00$ (via depósito bancário)

Informações e inscrições até 07 de agosto: pelo e-mail ajmc@ ajmc.com.br ou pelo telefone (11)3188-7252. 
Local: Bovespa - Auditório I (Abelardo) - Rua XV de Novembro, 275, $1^{\circ}$ andar

Mais informações para a imprensa:

Comunicare Consultoria de Comunicação - (11) 55944174

Adriana Cavalcanti - adriana@e-comunicare.com.br

Fabio Alberici de Mello - fabio@e-comunicare.com.br

Vivian Teixeira - vivian@e-comunicare.com.br

Prêmio BM\&FBOVESPA de Jornalismo 2008 recebe inscrições até o próximo dia 24

Em sua vigésima edição, premiação incluirá pela primeira vez o tema derivativos e prazo de envio de matérias vai até 24 de outubro

Estão abertas as inscrições para o Prêmio BM\&FBOVESPA de Jornalismo 2008. Até o próximo dia 24 de outubro, a Gerência de Imprensa BM\&FBOVESPA recebe matérias publicadas na mídia impressa e on-line de todo o país no período de 27 de outubro de 2007 a 24 de outubro de 2008. A ficha de inscrição e o regulamento já estão disponíveis para download na sala de imprensa do site BM\&FBOVESPA (http://www.bmfbovespa.com.br/portugues/imprensa.asp ).

Na sua vigésima edição, a premiação, inicialmente voltada ao mercado de capitais, foi reformulada para ampliar a participação da imprensa e incluir, pela primeira vez, matérias sobre os segmentos derivativos financeiros e agropecuários. Sendo assim, serão conferidos cinco prêmios, de $\mathrm{R} \$ 6$ mil cada, distribuídos em:

- três categorias para matérias que tratem do mercado de capitais, sendo dois prêmios para "Mídia impressa Rio-São Paulo", um prêmio para "Mídia impressa demais capitais e interior" e um prêmio para "Mídia on-line";

- uma categoria, com um prêmio, para matérias que tratem do tema "derivativos".

O Prêmio BM\&FBOVESPA de Jornalismo tem abrangência nacional. Cada jornalista poderá inscrever três trabalhos até o dia 24 de outubro de 2008, data-limite para o envio das matérias à BM\&FBOVESPA por meio eletrônico ou postadas pelo correio. A divulgação dos vencedores ocorrerá na cerimônia de premiação, no dia 28 de novembro. 
Criado em 1988, o Prêmio tem por objetivo o reconhecimento das matérias que representem uma contribuição efetiva para o desenvolvimento dos mercados de capitais e de derivativos brasileiro.

\section{Leia o regulamento atentamente e participe!}

1. O Prêmio BM\&FBOVESPA de Jornalismo visa a premiar, individualmente ou por equipe, o(s) autor(es) de matérias sobre o mercado de capitais e de derivativos que representem uma contribuição efetiva para o desenvolvimento dos segmentos no País.

Está dividido em cinco prêmios, de $\mathrm{R} \$ 6$ mil cada, distribuídos em quatro categorias, sendo:

$>$ Categoria "Mídia impressa Rio-São Paulo": dois prêmios para matérias sobre o mercado de capitais em jornais e revistas do Rio de Janeiro e São Paulo.

$>$ Categoria "Mídia impressa demais capitais e interior": um prêmio para matérias sobre o mercado de capitais em jornais e revistas de cidades brasileiras, exceto Rio de Janeiro e São Paulo.

> Categoria "Mídia on-line": um prêmio para matérias sobre o mercado de capitais em agências de notícias, sites e portais de todo o país.

$>$ Categoria "Derivativos": um prêmio para matérias sobre os mercados derivativos financeiros e agropecuários publicadas na mídia impressa e on-line de todo o país.

2. O prazo para as inscrições da edição de 2008 começa em 01 de setembro e termina em 24 de outubro de 2008 para postagem no correio ou envio por e-mail até às $18 \mathrm{~h}$.

3. Para concorrerem, as matérias devem ter sido publicadas no período compreendido entre 27 de outubro de 2007 e 24 de outubro de 2008.

4. É permitido ao jornalista inscrever até três trabalhos, individuais ou em parceria. Com exceção da categoria Mídia On-line, não serão aceitas, como uma única inscrição, matérias coordenadas com o texto principal, que configurem uma série ou caderno especial.

5. Os trabalhos devem ser encaminhados em versão eletrônica nas seguintes especificações: PDF da página inteira que traz a matéria inscrita, com até $2 \mathrm{MG}$, para o email bimprensa@bovespa.com.br. Também serão aceitas matérias em versão impressa, original sem redução, enviadas para a Gerência de Imprensa BM\&FBOVESPA, à Praça Antonio Prado, $48-6^{\circ}$ andar, Centro, São Paulo, CEP: 01010-901. O envelope deve mencionar na parte externa "Prêmio BM\&FBOVESPA de Jornalismo 2008".

6. Cada reportagem enviada, seja por meio físico ou eletrônico, deve vir acompanhada da ficha de inscrição disponível para download no endereço http://www.bmfbovespa.com.br/portugues/imprensa.asp .

7. Os profissionais que inscreverem trabalhos serão notificados, por e-mail, do recebimento do envelope pela Gerência de Imprensa da BM\&FBOVESPA.

8. Os trabalhos serão julgados por uma comissão composta por representantes da BM\&FBOVESPA e de entidades do mercado de capitais. A comissão é soberana e não serão aceitos quaisquer recursos contra suas decisões. 
9. O Prêmio BM\&FBOVESPA de Jornalismo é concedido anualmente e a empresa se reserva o direito de promover alterações em categorias, valores e outros itens do regulamento com o objetivo de aprimorá-lo a cada edição.

10. A inscrição no Prêmio BM\&FBOVESPA de Jornalismo é a confirmação de que regulamento foi aceito.

\section{BM\&FBOVESPA S.A.}

Diretoria de Comunicação

Gerência de Imprensa

Telefones: 55113119 2291/ 2450 / 2334

e-mail: imprensa@bmfbovespa.com.br

http://www.bmfbovespa.com.br

Novo Mercado: BVMF3 


\title{
ANEXO D
}

\author{
Exemplos de publicidade de empresa de media training. Material retirado dos sites das \\ empresas.
}

\author{
TRAMA COMUNICAÇÃO \\ CONSTRUINDO CONFIANÇA
}

MEDIA TRAINING

Prepara porta-vozes para entrevistas com a imprensa auxiliando-os a interagir de maneira segura com os jornalistas. O Media Training pode ser ministrado pela Trama de forma customizada em diferentes formatos para atender as necessidades específicas de cada perfil de organização e incluir:

- palestra teórica sobre o funcionamento da imprensa, seus bastidores e critérios para seleção da notícia, abordagens de um mesmo assunto por diferentes veículos;

- gravação de entrevistas para televisão, rádio, mídia impressa e online;

- simulação de situações positivas e negativas;

- palestras com fonoaudióloga, diretor teatral ou com profissionais de imprensa.

\section{Profissionais que atuam em nosso Media Training:}

Mariana Kotscho - Jornalista com 17 anos de experiência em televisão. Trabalhou no SBT, na TV Record e nos últimos 11 anos foi repórter da Rede Globo onde fez reportagens para todos os telejornais da emissora. Durante todos estes anos entrevistou pessoas a personalidades das mais diversas áreas: Presidentes da República, políticos em geral, empresários, artistas, intelectuais. Entre eles estão: Pelé, Xuxa, Lula, FHC, Gisele Bundchen, Raquel de Queiroz, Roberto Carlos, Roberto Freire, D.Paulo Evaristo Arns, Jean Claude Van Damme, Roger Moore. Em media training já treinou executivos de várias empresas em diversas áreas como telefonia, aviação, consultorias financeiras, bancos e órgãos públicos. É vencedora do prêmio Vladimir Herzog de jornalismo.

Davi de Almeida - Jornalista. Trabalha como repórter cinematográfico da Rede Globo para os programas Fantástico, JN, SPTV, Jornal Hoje e Jornal da Globo. Está no jornalismo de TV há 28 anos. Já passou pelas TVs Bandeirantes, Gazeta e extinta TV Manchete. Trabalhou em várias produtoras na área de publicidade, documentários e campanha eleitoral.

Cursou propaganda e marketing na universidade paulista, fez artes cênicas na PUC/SP, onde desenvolveu trabalho de ator, técnicas de postura e expressão corporal. Fez o curso de especialização em Comunicação Empresarial na FIAM/FMU. Há 15 anos aplicam todas essas técnicas e conhecimento nos trabalhos de media training para empresas e assessorias. Possui equipamento completo de gravação e captação de imagem para simulações de entrevistas.

Profa. Dra. Leny Rodrigues Kyrillos - Fonoaudióloga pela Universidade Federal de São Paulo - Escola Paulista de Medicina

Especialista em Voz pelo Conselho Federal de Fonoaudióloga - CFFa.

Mestre e Doutora em Ciências dos Distúrbios da Comunicação pela Universidade Federal de São Paulo Profa. Dra. dos Cursos de Fonoaudióloga, Jornalismo e Especialização em Voz da Pontifícia Universidade Católica de São Paulo PUC-SP, desde 2000.

Professora convidada do Curso de Especialização em Distúrbios da Comunicação Humana da Universidade Federal de São Paulo - Escola Paulista de Medicina, desde 1998.

Pesquisadora do Instituto da Laringe - INLAR-SP, desde 1991.

Co-autora do livro: "Voz e Corpo na TV - a fonoaudióloga a serviço da comunicação" (editora Globo - 2003) e organizadora dos livros: "Fonoaudióloga e Telejornalismo" (editora Revinter - 2002, 2003 e 2004 ) e "Expressividade" (editora Revinter - 2004).

Consultoria e assessoria de comunicação a diversas empresas, instituições financeiras e políticos, desde 1997. 
Responsável pelo atendimento a profissionais de rádio e televisão, desde 1989.

Autora de várias publicações científicas, nacionais e internacionais.

\section{S2 comunicação integrada}

I

A comunicação corporativa eficiente começa com o entendimento das necessidades dos jornalistas e do dia-a-dia das redações. O nosso programa "Treinamento de Executivos" capacita porta-vozes sobre como interagir com a mídia de maneira segura durante entrevistas ou encontros com jornalistas. Além disso, são apresentadas palestras sobre a importância da imprensa para os negócios e os parâmetros para a administração de crises por meio da comunicação corporativa.

O programa de Media Training da S2 Comunicação contempla:

- Formatos diferentes de eventos, com palestras e atividades customizadas, para atender as necessidades específicas de cada perfil de empresa e de executivos

- Exercícios práticos de administração de crise, com enfoque em casos hipotéticos desenvolvidos especialmente para cada companhia, em seu ambiente de negócios

- Palestras com profissionais de imprensa, de mídia impressa e eletrônica, sobre o diaa-dia das redações e o tratamento da notícia

- Treinamentos de entrevistas para televisão, rádio e mídia impressa, com jornalistas profissionais do mercado

- Esclarecimentos sobre o que é notícia para a imprensa e sobre as abordagens diferentes de um mesmo assunto em veículos específicos

- Diferenças de relevância entre espaço editorial e publicitário para as diferentes estratégias e atividades de comunicação 